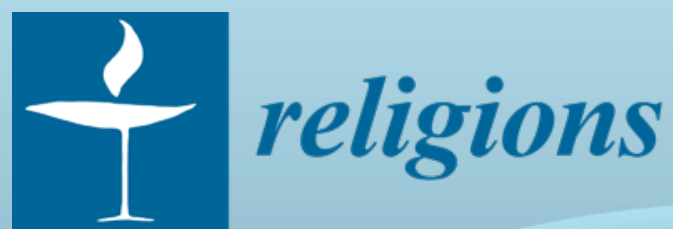




\section{Peace, Politics, and Religion}





\section{Peace, Politics, and Religion}

Editor

Jeffrey Haynes

MDPI $\bullet$ Basel $\bullet$ Beijing $\bullet$ Wuhan $\bullet$ Barcelona $\bullet$ Belgrade $\bullet$ Manchester $\bullet$ Tokyo $\bullet$ Cluj $\bullet$ Tianjin

\section{MDPI}


Editor

Jeffrey Haynes

London Metropolitan University

UK

Editorial Office

MDPI

St. Alban-Anlage 66

4052 Basel, Switzerland

This is a reprint of articles from the Special Issue published online in the open access journal Religions (ISSN 2077-1444) (available at: https://www.mdpi.com/journal/religions/special_issues/ Politics_Religion).

For citation purposes, cite each article independently as indicated on the article page online and as indicated below:

LastName, A.A.; LastName, B.B.; LastName, C.C. Article Title. Journal Name Year, Article Number, Page Range.

ISBN 978-3-03936-664-4 (Hbk)

ISBN 978-3-03936-665-1 (PDF)

(C) 2020 by the authors. Articles in this book are Open Access and distributed under the Creative Commons Attribution (CC BY) license, which allows users to download, copy and build upon published articles, as long as the author and publisher are properly credited, which ensures maximum dissemination and a wider impact of our publications.

The book as a whole is distributed by MDPI under the terms and conditions of the Creative Commons license CC BY-NC-ND. 


\section{Contents}

About the Editor $\ldots \ldots \ldots \ldots \ldots \ldots \ldots \ldots \ldots \ldots \ldots \ldots$

Jeffrey Haynes

Introductory Thoughts about Peace, Politics and Religion

Reprinted from: Religions 2020, 11, 242, doi:10.3390/rel11050242 . . . . . . . . . . . . . 1

Michał Gierycz

Religion: A Source of Fundamentalism or A Safeguard Against It?

Reprinted from: Religions 2020, 11, 104, doi:10.3390/rel11030104 . . . . . . . . . . . . . . 9

Laura Payne

What Can Faith-Based Forms of Violent Conflict Prevention Teach Us About Liberal Peace?

Reprinted from: Religions 2020, 11, 167, doi:10.3390/rel11040167 . . . . . . . . . . . . . . 29

Christine Schliesser

Religion and Peace-Anatomy of a Love-Hate Relationship

Reprinted from: Religions 2020, 11, 219, doi:10.3390/rel11050219 . . . . . . . . . . . . . 45

Joanna Kulska

Religious Engagement and the Migration Issue: Towards Reconciling Political and Moral Duty

Reprinted from: Religions 2020, 11, 236, doi:10.3390/rel11050236 . . . . . . . . . . . . . . 57

\section{Peter Friedlander}

Reassessing Religion and Politics in the Life of Jagjivan Rām

Reprinted from: Religions 2020, 11, 224, doi:10.3390/rel11050224 . . . . . . . . . . . . . 77

\section{Netta van Vliet}

Israelijew Jewisraeli: Yoram Kaniuk's Adam Resurrected and the Problem of the Human

Reprinted from: Religions 2020, 11, 157, doi:10.3390/rel11040157 . . . . . . . . . . . . . . 95

\section{Joram Tarusarira}

When Piety Is Not Enough: Religio-Political Organizations in Pursuit of Peace and

Reconciliation in Zimbabwe

Reprinted from: Religions 2020, 11, 235, doi:10.3390/rel11050235 . . . . . . . . . . . . . 111

\section{Bekithemba Dube}

'Go and Prophesy in Your Own Land': Foreign Prophets and Popularism in South Africa.

Evoking the Need of Jonathanic Theology for Peaceful Resolution of Difference

Reprinted from: Religions 2020, 11, 42, doi:10.3390/rel11010042 . . . . . . . . . . . . . . . 127

\section{Kangdim Dingji Maza, Umut Koldas and Sait Aksit}

Challenges of Countering Terrorist Recruitment in the Lake Chad Region: The Case of

Boko Haram

Reprinted from: Religions 2020, 11, 96, doi:10.3390/rel11020096 . . . . . . . . . . . . . . . 139

\section{Dino Krause, Isak Svensson and Göran Larsson}

Why Is There So Little Shia-Sunni Dialogue? Understanding the Deficit of Intra-Muslim

Dialogue and Interreligious Peacemaking

Reprinted from: Religions 2019, 10, 567, doi:10.3390/rel10100567 . . . . . . . . . . . . . 165 


\section{Xabier Itçaina}

Catholic Mediation in the Basque Peace Process: Questioning the Transnational Dimension Reprinted from: Religions 2020, 11, 216, doi:10.3390/rel11050216

\section{Lee Marsden}

International Religious Freedom Promotion and US Foreign Policy

Reprinted from: Religions 2020, 11, 260, doi:10.3390/rel11050260 


\section{About the Editor}

Jeffrey Haynes is professor emeritus of Politics at London Metropolitan University. Among his recent publications are: Religion, Conflict and Post-Secular Politics, London, Routledge, 2020, and The Routledge Handbook to Religion and Political Parties (ed.), London: Routledge, 2020. 

Editorial

\title{
Introductory Thoughts about Peace, Politics and Religion
}

\author{
Jeffrey Haynes \\ School of Social Sciences, London Metropolitan University, London N7 8DB, UK; tsjhayn1@londonmet.ac.uk
}

Received: 23 April 2020; Accepted: 5 May 2020; Published: 13 May 2020

\begin{abstract}
Recent years have seen a growing literature on the interactions between peace, politics and religion, including their diverse and often complex relationships. Underpinning this literature is an increase, more generally, in scholarly and policy interest in connections between religion and politics. The context is that over the last three decades, religion has made a remarkable return to prominence in various academic literatures, including sociology, political science and international relations. This was a surprise to many social scientists and confounded the expectations of both secularization theorists and secularists. In addition, religion retained a strong, some say growing, significance as a core source of identity for billions of people around the world. Numerous religious leaders and faith-based organizations are important carriers and focal points of religious ideas, playing an important role in many countries, both developed and developing, as well as internationally, including at the United Nations and to a lesser, although still notable extent, in the European Union and other regional organizations. This introductory article examines interactions between religious entities in relation to peace and conflict and sets the scene for the articles comprising this volume.
\end{abstract}

Keywords: peace; politics; conflict; religion; faith; faith-based organizations

Recent years have seen a growing literature on the interactions between peace, politics and religion, including their diverse and often complex relationships. Underpinning this literature is an increase, more generally, in scholarly and policy interest in connections between religion and politics. Sind the 1980s, there has been renewed scholarly interest in the social sciences regarding how religion affects outcomes in the discipline's various sub-disciplines, including the study of politics. Many social scientists were very surprised by this development; most at this time were adherents of the secularization thesis. This maintained that as societies modernized they would inevitably secularize. Things turned out differently: instead, religion has retained a strong, some say growing, significance as a core source of identity for billions of people around the world. In addition, numerous religious individuals and faith-based organizations (FBOs) are important carriers and focal points of religious ideas. They play an important role not only in numerous countries around the world, but also in some of the world's major international organizations, including the United Nations, the European Union and the Organization of Islamic Cooperation.

Why does social science now pay more attention to what religion does in terms of outcomes? It is often suggested that religion has an important, sometimes pivotal role, in conflict. Religion can either be a cause of conflict, or a key component in helping resolve conflict. In addition, once religion has established a key role in ending conflict, it may then pay a role in helping build sustained peace. That being said, it is certainly the case that when someone is asked how they regard the role of religion in various aspects of conflict, then many would suggest that it is noteable primarily for causing or exacerbating conflict, not helping resolve it. In this respect, there is much empirical evidence amassed over the last few decades to substantiate the notion that religion is more the problem than the solution to many of the world's more enduring conflicts, both within countries and between them. In the West, for example, religious hatred characterized the recently quelled conflict in Northern Ireland, while in the USA, culture wars between religionists and secularists have widened and deepening during 
the controversial presidency of Donald Trump. On the other hand, there is growing evidence that religious leaders and FBOs can, if so minded, play highly constructive roles in helping end societal violence and interstate conflicts. How might they do this? They can alert their followers and others to the dangers that an emerging conflict poses for societal harmony, they can do their best to help resolve conflicts when the have begun, and they can be advocates for peace and conflict resolution. They can offer to be mediators between conflicting parties and can seek to bring them together once peace is won. In short, contemporary discussions about the relationship between peace, politics and religion necessarily highlight that religion can both encourage conflict and peace, through the activities of people individually and collectively, imbued with faith-based ideas and ideals.

Given the often-messy nature of religiously-informed conflict, it is no surprise that we do not have a sole, sophisticated theoretical model enabling us to understand clearly all the applicable cases of religion's relationship with peace and politics. We can, however, note that often the involvement of religion in conflict comes in the context of what might be called "good governance" issues, which are in turn often linked to the multiple impacts of globalization both within and between countries. The impact of post-Cold War globalization-which I characterize as having four main, interactive dimensions: economic, political, cultural and technological—may highlight or exacerbate previously dormant religious tensions, often by undermining or dismantling traditional value systems, which cannot cope with the changes which globalization brings. It is often suggested that, as a result, numerous people feel increasingly bewildered and distressed, and their attentions may turn to religion to help them recover their equilibrium and sense of wellbeing. Put another way, numerous (re)turn to faith to (re)discover a lost sense of comfort, serenity, stability, as well as to uplift themselves spiritually. There is however another potential impact: (re)discovering faith may also encourage believers to experience novel or changed feelings of identity. On the one hand, this can lead to helping provide them with renewed meaning and purpose. On the other hand, it can encourage them to regard others with disfavour or distaste and the outcome can be new or heightened interreligious competition and conflict, making pursuit of peace especially problematic.

It is widely noted that post-Cold War globalization has led to greatly increased global interactions between people and communities. As a result, over the last three decades encounters between people of differing religious traditions have become increasingly common-although, sadly, this has not always led to increasingly harmonious outcomes. Such conflicts, involve, variously, small groups or larger sections of people, who self-identify by their and others' racial, ethnic or religious characteristics, and find reasons for tensions or conflict as a result. Such conflicts can become all-consuming and very difficult to resolve, as they appear to many as existential struggles between "good" against "evil", with religion as a dependent variable. This development is played out in some countries, for example, in Iran and the USA, and characterized by the outbreak of "culture wars" between strongly religious and stridently secular people. Such culture wars can be seemingly endless; there may seem no room for compromise between two polarised worldviews, which encourage very different allegiances and standards in certain fundamental aspects of life, including: family, law, education and politics.

We have noted that societal and political conflicts may have significant religious dimensions, whereby real or perceived related differences between people can drive both hatred and violence. The implication is that religious actors, including religious leaders and FBOs, can be characterized, albeit generally, predominantly as those who pursue peace avidly and those who are more concerned with triumphing in a conflict, if necessary by the sustained use of force. Religion's inconsistency in this respect stems from the fact that the world religions-Buddhism, Christianity, Hinduism, Islam and Judaism,-all have ambivalent views about peace, cooperation, violence and conflict. Such inconsistency is made clear when we think about various manifestations of religious involvement in large-scale conflicts. For example, large-scale violence in sub-Saharan Africa, Asia and other parts of the world is often associated with serious social conflicts, many of which significantly involve levels of religious, cultural and/or civilizational tensions (Haynes 2019a). Yet, in virtually all such cases, what appear to be religious tensions that erupt into conflict and violence are also intimately linked to other, 
non-religious, issues, including: ethnicity, gender, culture, class, power and wealth. Such strains and stresses may be played out both within countries in recent years, in, for example, Northern Ireland, Egypt, Nigeria, Fiji, Cyprus, Sri Lanka, or between them, for example, India and Pakistan, and Israel and Palestine (Haynes 2019b).

Let me be clear: I am not suggesting that religion's involvement in societal or political interactions always leads to conflict or even challenges to peace or the status quo. What I am suggesting is that religion's inconsistency in this regard is reflected in the fact that it can play a significant role in attempts to resolve inter- and intra-group clashes and help build peace, or it can stimulate or exacerbate a decline of the peace. This also underlines how the traditions underpinning and informing many religious expressions, including the five world religions, contain often multiple references to conflict and division and their consequences in terms of group harmony. The world religions also have a lot to say about how their followers should behave in order to achieve greater intersocietal harmony and peace not only among fellow believers abut also in relation to those of a different religion. These issues have provided the stimulus to numerous books, book chapters, journal articles, blogs and reports since the 1980s. Many valuable sources in relation to religion, conflict and peace are noted or analysed in the articles which make up the special issue, so I will not provide a comprehensive list here. The key point to note is that, while often differing greatly in terms of subject matter and conclusions, collectively they focus on how sundry religious actors can play a role in stimulating, exacerbating or helping arrive at the termination of conflicts. Seeking to summarize a huge set of findings regarding religious peacebuilding and what is often referred to as "faith-based diplomacy", we can note the following, derived from Appleby's (2006) thought provoking and influential work on this topic:

- Religious leaders and FBOs are uniquely positioned to foster nonviolent conflict transformation through the building of constructive, collaborative relationships within and across ethnic, religious, cultural or civilizational groups, for the common good of a country or region's entire population.

- In many conflict settings around the world, the social location and cultural power of religious leaders and FBOs can make them potentially critical players in efforts to build sustainable peace among conflicting groups.

- The multigenerational local or regional communities that religious leaders are connected to are often singular repositories of local knowledge and wisdom, custodians of culture and/or civilization, and privileged sites of significant moral, psychological and spiritual formation.

These communities are symbolically charged sources of personal as well as collective identity, which typically establish, maintain and help embed essential educational and welfare institutions, often serving the entire community and not just specified followers of a particular religious tradition (Appleby 2000, 2006).

\section{Societal and Political Conflicts: Religion as a Potential Bridge towards Peace}

As we have already noted, the premise of religious involvement in both conflict and peacemaking and peacebuilding points to all five world religions. We also took in to account that interactive processes of globalization lead to greatly increased interactions between people, including those who are widely separated geographically and culturally. Finally, we have seen that as a consequence of enhanced globalization over the last 30 years, encounters between followers of various religious traditions have also increased greatly. That they are not always harmonious is obvious; we have seen that religion is often regarded by social scientists as a key cause of tensions and conflict in many parts of the world, both within and between countries. This is the case with, for examples, the decades-long Israel/Palestinians culture wars and that involving Kashmir, consistently squabbled over by successive governments in Pakistan and India, as well as in the United States today, during the Trump presidency in relation to, for example, abortion, education, and LGBTQ and women's rights (Haynes 2019b). What causes such culture-based conflicts? According to Kurtz, they surface, develop and consolidate because of conflicting cultural worldviews, very often with a pronounced religious dimension. Such 
issues tend to exacerbate already-present areas of tension, leading them into various fundamental areas, typically linked to societal, gender, state, territorial, and/or political topics. A result is that they "take on 'larger-than-life' proportions as the struggle of good against evil" (Kurtz 1995, p. 170). According to the eminent Roman Catholic theologian, Hans Kung,

[T] he most fanatical, the cruelest political struggles are those that have been colored, inspired, and legitimized by religion. To say this is not to reduce all political conflicts to religious ones, but to take seriously the fact that religions share in the responsibility for bringing peace to our torn and warring world.

(Kung cited in Smock 2004)

In short, many contemporary conflicts have religious and/or cultural roots, increasing both hatred and violence and driving communities apart.

As already noted, religious leaders and FBOs can function either as core actors in the benign pursuit of peace or in the tragic development of serious and sustained conflict. What Scott Appleby (Appleby 2000) calls the ambivalence of the sacred is intimately linked to the fact that the relationship of the world religions to violence is itself indecisive. As Holenstein (2005, p. 10) reminds us

All great God-narratives are familiar with traditions that legitimise force in certain circumstances, claim victims in the battle for their own beliefs and demonise people of other religions. However, at the same time there are sources that proclaim the incompatibility of violence with religion, demand sacrifices for peace and insist on respect for people of other religions. If we are to assume that, for the foreseeable future, the religions of the world will continue to be a factor in political conflicts, then it is high time that we strengthened the "civilising" side of the sacred and made it more difficult for it cynically to be taken over by political interests. What is said here about the relationship of world religions to violence can be considered generally valid for religions overall.

The problem is that while most religious believers would no doubt believe that their faith is both compassionate and inspirational, the ideas underpinning a particular faith-driven view of the world are also often implicated in the eruption of violence and conflict both between and within religious groups (or at least entities with a religious component to their guiding ideology). In recent years, a massive literature has appeared on religious contributions to conflict and violence (see, for example, National Commission on Terrorist Attacks 2004). Various armed groups, such as al-Qaida, Islamic State, Boko Haram, and Al Shabaab, claim religious justification for their murderous activities (For a discussion, see Haynes 2013).

Such extremist Islamist groups are collectively informed by similar jihadi ideologies. A key component if the development of today's jihadi ideologies was the epochal event of 11 September 2001 (9/11). The al-Qaida attacks on the United States was an issue of fundamental importance to continuing jihadi conflicts with Western-especially Christian-countries. Put another way, it seems likely that without 9/11 the world would not have devoted many years and trillions of dollars fruitlessly to fighting "jihadi terrorism".

One of the tragic outcomes of $9 / 11$ and its aftermath was that globalization clearly increased both the potential and the actualization of violence from extremist non-state actors with religious ideologies-who might be physically located almost anywhere-against states. Before 9/11, governments of powerful countries like the USA believed that their national territories were largely impervious to external attack because of their high-cost militaries and national defence plans. What the 9/11 attacks made crystal clear, at a stroke, was that geographical space- until then believed to be an impenetrable barrier to attacks from external actors except from those from nuclear weapons-no longer mattered. Having said that, al-Qaida's attacks on the Twin Towers and the Pentagon on 9/11 made the task much more difficult of seeking to understand what role religion can play in reducing conflicts and building peace. What was clear was that henceforward there was a sudden, 
urgent new challenge to our understanding of global politics, including its relationship to domestic politics. Now, the state's "hard shell" was forever breached. According to Smith (2002, p. 177), this suggested an important connotation for future chances of world order, because states were "no longer, if they ever were, the key actors in major international arenas". Thus, the kind of international terrorism exemplified by al-Qaida in relation to 9/11 and more recently from the so-called Islamic State does not 'map onto state structures', but 'works in the spaces between them'. What 9/11 also illustrated regarding the relationship between peace, politics and religion was that some of the most dangerous and committed of international threats to peace-such as, from al-Qaida, Islamic State, Boko Haram, and Al Shabaab-are not inevitably focused on acquiring territory per se. Instead, what they want to achieve is primarily defined by their desire to spread their values and beliefs via ideologically driven methods. The obvious implication of this is that today's jihadi groups are very different types of organization compared to the conventional notion of the state, both in terms of identity and structure. Their structures are the reverse of the modern state, characterized by a hierarchy of power and authority, while its identity is nebulous (Haynes 2013).

More generally, in recent years various religious expressions have been centrally implicated in many domestic and international conflicts. This is because sustained and implacable religious conviction contains within it at least four discrete sources of danger:

- "Religion is focused on the absolute and unconditional and as a result can adopt totalitarian characteristics". Christianity, Islam and Judaism are the three Abrahamic religious faiths. It is sometimes suggested that these three religions in particular may sometimes find it rather problematic to tell the essential differences between, on the one hand, what God states to be true, and, on the other, what humans actually do and say.

- "When claiming both absolute and exclusive validity, religious conviction can lead to intolerance, over-zealous proselytization and religious fragmentation". This suggests that if one believes everything that a religion asserts is true, then this can lead to doubts about the veracity and viability of pluralism and liberal democracy.

- "Religion can increase aggressiveness and the willingness to use violence". Religious convictions have great symbolic value. This can lead to what initially start as irreligious motivations or goals taking on the aspect over time of "holy" objectives.

- $\quad$ "Leaders within faith-based organizations may seek to legitimize abuses of power and violation of human rights in the name of religious zeal". It is often noted that many religious faiths regard females as subservient to men, domestically, socially, politically and economically. Because religious leaders are nearly always men, then the subservient faith-derived roles of women in these respects may not receive the attention it deserves (Haynes 2019a, pp. 656-57).

In addition, those who hold religious power may also adopt the following tactics in order to bolster or strengthen their positions:

- A political focus on "identity' is likely to raise and perhaps exploit differences with others characterized by "ethnic-cultural" and/or "cultural-religious" dimensions.

- Jihad groups among other, almost invariably led by men, use claimed religious motivations to conduct their activities.

- Heads of fundamentalist religious groups "lay claim to a single and absolutist religious interpretation at the cost of all others, and they link their interpretation to political power objectives" (Holenstein 2005, p. 11).

Kurtz refers to the last point as "exclusive accounts of the nature of reality". What he means by this is that followers of fundamentalist religious expressions only accept the religious beliefs that they claim are the solely true dogmas (Kurtz 1995, p. 238). Once again, the three Abrahamic religions are noted in this regard. This is the case because fundamentalist expressions of each of the three religions base their truth claims on each faith's recognized holy books. Such readings lead to exclusivist truth 
claims which are not only undeniable but also can lead to conflict with those who do not accept their "truths". It is obvious that engaging with religious ideas without a mindset that can accept the need for compromise will likely lead to unremitting conflict with those with different beliefs. This is especially the case in today's highly globalized world. "On the other hand, many religious traditions have within them beliefs that can help develop a peaceful, multicultural world. For example, from within Christianity comes the idea of nonviolence, a key attribute of Jesus, the religion's founder, who insisted that all people are children of God, and that the test of one's relationship with God is whether one loves one's enemies and brings good news to the poor. As St. Paul said, 'There is no Jew or Greek, servant or free, male or female: because you are all one in Jesus Christ' (Galatians 3: 28)" (Haynes 2013, p. 657).

It is suggested that "all religious traditions contain references in the form of didactical stories, teaching or even direct recommendation as to how the faithful should act in order to achieve harmony and peace within him/herself in the first place" (Bartoli 2005, pp. 5-6). As Bouta et al. (2005) note, when it comes to seeking to resolve inter-societal conflicts then religions-variously individuals and groups-often are noteable by their attempts to make things better. Note that such attempts are not only a product of current times. Over the last half century or so, there have been examples, albeit sometimes intermittent rather than necessarily sustained, which point to a consistent involvement of religious individuals and/or representatives of various FBOs in many such efforts. "Examples include intermediation undertaken by the Quakers and financed by the Ford foundation in the Nigerian Civil War in 1967-1970, the work of the World Council of Churches and the All Africa Conference of Churches in mediating a cessation to the Sudan conflict in 1972, efforts made by John Paul Lederach, Professor of International Peacebuilding at the University of Notre Dame, in Nicaragua in the 1980s, and the more recent work of the Imam of Timbuktu in seeking to end various conflicts in West Africa (Conflict and Resolution Forum 2001)" (Haynes 2013, p. 658). The conclusion to draw from this is that it is not appropriate or necessary to assess the role of religion in conflicts and draw the conclusion that religions always makes things worse. On the contrary, this would overlook the many attempts over the years of religious entities to improve conflicts and help build peace. Sadly, however, conflicts are much more newsworthy that religious leaders' often problematic attempts to end conflicts and build peace. But this does not mean that they should be summarily disregarded or dismissed. Even unsuccessful attempts can be important components in the eventual building of peace, even if in the short term such efforts do not seem to meet with obvious success.

Appleby (2006) claims that religious peacemakers are most likely to contribute usefully to ending conflict when they: (1) seek to work internationally or transnationally, (2) consistently highlight the importance and desirability peace and point to the obvious and clear costs of conflict, and (3) pursue good inter-religious relations-even when a conflict is ongoing, as this will be an important builder of trust when trying to develop peace after conflict the key to a positive input from them. It is often noted that the three Abrahamic religions share a broadly similar set of theological and spiritual values and views and this potentially underpins their ability to provide positive contributions to conflict resolution and peacebuilding.

In conclusion, contributors to Smock's (2006) edited volume identify the following of importance when examining often complex issue of religious involvement in conflict, conflict resolution and peacebuilding:

- Although often involved in conflict it is important not to overlook the often constructive efforts of religious leaders and FBOs in attempts to curtail conflict and build peace. Religious leaders and FBOs typically have important roles trying to resolve religious conflicts. In addition, such entities are often called upon by non-religious combatants to try to address their conflicts. This is because religious leaders may be highly trusted by both sides in a conflict.

- Attempt to build peace undertaken under religious leadership may not differ that much from those undertaken by secular actors, such as governments and nongovernmental organizations (NGOS). On the other hand, their religious emphasis nearly always informs their specific approaches to peacebuilding agendas and programmes. 
- Faith attempts to end conflict and build peace are various, varying between high-level mediation to training and peacebuilding-through-development focused on communities.

- Peace is often promoted most efficiently by including overt peacebuilding components into associated but different relief and development activities (Smock 2006).

Finally, faith-based peacebuilding initiatives "have contributed positively to peacebuilding" in four main ways. They can provide (1) "emotional and spiritual support to war-affected communities", (2) effective mobilization for "their communities and others for peace", (3) mediation "between conflicting parties", and (4) a conduit in pursuit of "reconciliation, dialogue, and disarmament, demobilization and reintegration" (Bouta et al. 2005, p. ix). We can also note the promise that religious peacemakers offer, while also pointing to two problems: (1) "there is often a failure of religious leaders to understand and/or enact their potential peace-building roles within the local community", and

(2) many religious leaders lack the ability to "exploit their strategic capacity as transnational actors" (Appleby 2006, p. 2). Such concerns arise in a global region of apparently growing political and societal tensions: the Middle East. Escalating tensions following the Arab Uprisings of 2011 serve to underscore both the potential importance of interreligious dialogue while also highlighting the roles of local and international actors to aggravate existing tensions-for example, in relation to Israel and the Palestinians or Iran and Saudi Arabia—and makes finding common ground even harder to achieve and, by extension, pursuit of peace in the region is (even) more problematic.

\section{Conclusions}

This Special Issue of Religions, focusing on 'Peace, Politics and Religion', incorporates theoretical, comparative and case studies to examine these and other issues.

What do we now know about the crucial relationships between peace, politics and religion? The issue, it seems clear, is not generally about religion per se, or even about religious differences that necessarily cause irresolvable conflicts. Instead, such conflicts develop, due to a number of causes, which are typically as much about material concerns as they are about differing views of the world deriving from their religious interpretations. But when we add religion to the issues which are causing conflict, then they tend to be harder to resolve. This is because, it seems, religious differences often seem particularly unamenable to compromise and can lead to various sets of believers coming to the conclusion that it is better to fight to the bitter end than 'betraying' God by appearing to "give in" to the enemy.

A second concluding point is that those individuals, groups and communities motivated by their religious worldviews may find it much harder to build durable peace as the foundation of better harmonious relations, without drawing on the helpfulness and recognition of significant non-religious people, that is, those who are especially affected by the conflict and have a significant stake in resolving it. Put another way, this is to underline that notwithstanding the often sincere intentions of those seeking to diminish religious disagreements through discourse and improved understanding, such a process is only likely to include those who agree that such an approach is likely to be beneficial to all in the long run. On the other hand, such an approach is likely to fail if it does not convince those who are especially willing to use violence as a key strategy in pursuit of an unachievable goal, whether it be a global Islamic State or an ethnically-cleansed Northern Ireland.

Finally, religion can end up being a relatively marginal issue in wider conflict scenarios, some of which are analysed in the Special Issue's constituent articles. What they emphasise is that while of course religion is 'important' in a scholarly sense, it is absolutely vital to many millions of "ordinary" people and to tiny numbers of extremists who are willing to use prolonged violence to try to achieve their goals. But a wider point may warrant repetition: serious conflicts involving religion nearly always involve not only the impact of religious difference as such, but also other equally important material and existential issues: such as, territory, employment, security, culture, civilization, ethnic group, fear and hope. 
Funding: This research received no external funding.

Conflicts of Interest: The author declares no conflict of interest.

\section{References}

Appleby, R. Scott. 2000. The Ambivalence of the Sacred: Religion, Violence, and Reconciliation. Lanham: Rowman and Littlefield.

Appleby, R. Scott. 2006. Building sustainable peace: The roles of local and transnational religious actors. Paper presented at the Conference on New Religious Pluralism in World Politics, Georgetown University, Washington, DC, USA, March 17.

Bartoli, Andrea. 2005. Conflict prevention: The role of religion is the role of its actors. New Routes 10: 3-7.

Bouta, Tsjeard, S. Ayse Kadayifci-Orellana, and Mohammed Abu-Nimer. 2005. Faith-Based Peace-Building: Mapping and Analysis of Christian, Muslim and Multi-Faith Actors. The Hague: Institute of International Relations.

Conflict and Resolution Forum. 2001. Faith-Based Peacemaking: The Role of Religious Actors in Preventing and Resolving Conflict Worldwide. Speakers: Dr. David Smock and Dr. Barry Hart. Available online: https://www.sfcg.org/Documents/CPRF/CPRFApril2001.pdf (accessed on 8 May 2020).

Haynes, Jeffrey. 2013. Religion, conflict and peace. Peacebuilding 1: 159-64. [CrossRef]

Haynes, Jeffrey. 2019a. Peace, politics and religion. In The Palgrave Handbook of Global Approaches to Peace. Edited by Aigul Kulnazarova and Vesselin Popovzki. New York: Palgrave Macmillan, pp. 643-62.

Haynes, Jeffrey. 2019b. From Huntington to Trump: Thirty Years of the Clash of Civilizations. New York: Lexington Books.

Holenstein, Anne-Marie. 2005. Role and Significance of Religion and Spirituality in Development Co-Operation. A reflection and working paper. Translated from German by Wendy Tyndale. Bern: Swiss Agency for Development and Co-operation.

Kurtz, Lester. 1995. Gods in the Global Village. Pine Forge: Sage.

National Commission on Terrorist Attacks. 2004. The 9/11 Commission Report: Final Report of the National Commission on Terrorist Attacks Upon the United States. New York: W.W.Norton.

Smith, Steve. 2002. The end of the unipolar moment? September 11 and the future of world order. International Relations 16: 171-183. [CrossRef]

Smock, David. 2004. Divine intervention: Regional reconciliation through faith. Harvard International Review 25: 46-50.

Smock, David, ed. 2006. Religious Contributions to Peacemaking: When Religion Brings Peace, Not War. Leiden: Brill.

(C) 2020 by the author. Licensee MDPI, Basel, Switzerland. This article is an open access article distributed under the terms and conditions of the Creative Commons Attribution (CC BY) license (http://creativecommons.org/licenses/by/4.0/). 


\title{
Article \\ Religion: A Source of Fundamentalism or A Safeguard Against It?
}

\author{
Michał Gierycz \\ Institute of Political Science and Public Administration, Cardinal Stefan Wyszyński University in Warsaw, \\ Wóycickiego 1/3, bud.23, 01-938 Warsaw, Poland; m.gierycz@uksw.edu.pl
}

Received: 29 January 2020; Accepted: 18 February 2020; Published: 26 February 2020

\begin{abstract}
This article contributes to critical reflection on the political study approach towards the relations between religion and fundamentalism. In the context of post-secularism, in which the cognitive and moral role of religion for politics is quite widely recognised, the aim is to discuss three hypotheses. The first one argues that, contrary to what the majority of the subject's literature maintains, fundamentalism is not only a strictly religious phenomenon, but a specific attitude, able to evolve equally well on both religious and secular foundations. The second one implies that secularisation encourages, at least to an equal degree, both profane and religious fundamentalist tendencies. The third thesis asserts that religion, in its nature, constitutes a potential safeguard against fundamentalism. In the course of analysis, the pertinence of the above hypotheses are generally demonstrated. However, it is also indicated that the third point constitutes a mid-range theorem, accurately describing the contemporary specificity of Christianity, and especially Catholicism.
\end{abstract}

Keywords: fundamentalism; religion and politics; secularism; political science; Islam; Catholicism; Protestantism

\section{Introduction}

The title of this article may appear provocative. Quite commonly in literature on fundamentalism, authors present it as a strictly religious phenomenon (Pratt 2020; Cowden and Sahdal 2017; Rausch 2015; Ozzano 2009; Marczewska-Rytko 2007; Armstrong 2000; Bruce 2000). The problem is that such a view, quite widespread within the political science of religion, which explicitly or implicitly takes the secularisation paradigm as an axiom (Gierycz 2019, pp. 42-45), is far from self-evident and requires critical analysis. There is much to suggest that (1) fundamentalism is not a strictly religious phenomenon, but rather a specific way of thinking and acting which may thrive in secular just as well as in religious soil; (2) secularisation enhances secular just as much as religious fundamentalist tendencies; (3) religion is, by its very nature, a potential safeguard against fundamentalism. Whether or not it does play such a role in real life is related, to a large extent, to the character of a particular religion. This article discusses these three hypotheses in an attempt to contribute to a critical reflection on the way the relationship between religion and fundamentalism is viewed in the political science of religion.

The problem with any research on fundamentalism is, however, that it seems to be a fuzzy concept, lacking any explicit "semantic contours" (Bielefeldt and Heitmeyer 1998, p. 11, cf. Riesebrodt 2004). It is worth noting that even though the notion of fundamentalism first emerged in the beginning of the 20th century in the context of disputes within American Protestantism, it did not become prevalent in political rhetoric or academic discourse until the end of the 1970s and the revolution in Iran (Haynes 2010). Consequently, the term "fundamentalists" is nowadays used to refer, almost in the same breath, to American Protestants of the end of the 19th century, their distant cousins gathered around the Moral Majority in the second half of the 20th century, and the Islamists of the turn of the 20th and 21st 
centuries. The very fact that groups so distant from one another, both timewise and in terms of the ends and the means used to achieve them, are classified into a single category seems to substantiate the claim that there are some semantic problems involved in the notion. One can hardly fail to notice that in political discourse the notion of fundamentalism is often treated as a stigmatising term, aimed at discrediting a political opponent (Janicki and Władyka 2015). Consequently, in everyday usage it does not belong so much to the parlance of political science but to that of politics, playing an ideological rather than an explanatory role. In view of all of these considerations, before going into a more detailed analysis of the relationship between religion and fundamentalism it is necessary to explain how the notion may be understood in political science and to at least sketch out a theory of fundamentalism which could be used when describing and explaining political phenomena. To this end, it seems advisable to go back to the sources: to the historical context in which the notion of "fundamentalism" first appeared.

\section{Two Interpretations of the Term "Fundamentalism"}

The term "fundamentalist" was first used in the United States to describe the proponents of a series of Protestant publications entitled The Fundamentals, which defended a literal interpretation of the Scripture. Their publication was a reaction to the progressing domination, especially among the Lutherans and the Calvinists, of a historical and critical exegesis of the Bible, with its characteristic scientism and positivism. With an aim of "liberating" the Biblical text of anything that could not be reconciled with a rationalist logic, critical exegesis in fact undermined the entire supra-rational dimension of the Revelation: anything that looked like a myth or referred to apparently miraculous phenomena (Schlegel 2003). In opposition to a modernist direction in biblical interpretation, in the years 1910-1915 a group of American Protestants published a series of booklets which, as announced by their title (The Fundamentals), defended "fundamental matters"; indisputable truths of the faith, opposing the modernist tendencies in Protestantism. The booklets discussed biblical and doctrinal issues (the salvific role of the cross, the resurrection of Jesus, the infallibility of the biblical text), as well as matters of worldview (booklets aimed against the Catholic Church, socialism, Darwinism, etc.). Protestants supporting The Fundamentals believed in a literal interpretation of the Scripture, ruling out any symbolic or moral reading of biblical texts (Schlegel 2003). One frequently cited example of this approach was the claim that the world's creation in six days should be unquestioningly accepted. In fact, this issue became the source of a social depreciation of the fundamentalist stance following the Scopes Monkey Trial of 1925. The trial also significantly affected the character of the term "fundamentalism" itself; even though initially it did not include a value judgement, after the Scopes Monkey Trial it acquired a pejorative ring.

The fundamentalist experience at the turn of the 19th and 20th century can be read in two ways which lead to two approaches of fundamentalism today. On the one hand, it may be stressed that fundamentalism was initially an objection to a relativisation of the Revelation. In this perspective, fundamentalism may be understood as an approach which looks for absolute, universal foundations of knowledge (Kijas 2010), and thus as the opposite of relativism. Understood this way, fundamentalism refers to the cognitive attitude to reality. In this approach, which may be called substantial, the notion of "fundamentalism" does not contain a value judgement. According to Ernest Gellner, fundamentalism understood in epistemic terms in fact represents, in both its religious and its rationalist version, one of the two possible (the other being relativism) essential worldviews. In this perspective, a religious fundamentalist is simply someone who accepts religion in its full form as the foundation of knowledge about reality, without attempting to "bend" or relativize, compromise or mitigate (Sacks 1991), one who represents "strict adherence" to religious doctrine (Rausch 2015, p. 29) while believing that its doctrine presents the fundamental truth about God and the human condition. A secular version of such an understanding of fundamentalism would be a rationalist fundamentalism which continues the tradition of the Enlightenment revolution in science and which is an option for all those who do not have religious faith, but who reject the intellectually insubstantial offer of relativism (Gellner 1992). 
While the approach to fundamentalism outlined above may help introduce some order into philosophical or theological discussions, it does not seem satisfactory from the perspective of a political scientist. In the political perspective, the notion of fundamentalism seems to mean something else. In order to make this difference evident, it is enough to point out that if religious fundamentalism were to be defined as "consistent religiousness" in the context of the secular age, this would mean a "fundamentalist affiliation" of both Ayatollah Khomeini and Pope Francis, or-referring to groups-the Pentecostal charismatic movements and organisations like Gush Emunim. The explanatory value of this approach is-as far as political perspective is concerned-practically null, since in this way a fundamentalist is both someone who accepts violence as a form of political struggle and one who rejects such methods, one who respects human rights and one who does not, one who strives for absolute power and one who makes no such claims, etc. The only sensible conclusion in such an approach would appear to be the confession made by Steve Bruce, who says in the summary of his book that "we do not need an explanation of fundamentalism as such" (Bruce 2000, p. 122).

If we can see, however, that there is a significant difference between the Muslim Brotherhood and the Fraternities of Jerusalem, we must conclude that there is a specific type of religiousness or, more broadly, perception of reality different from its other forms. In this approach, our attention is focused not so much on the content of beliefs or worldviews, but on the form in which they are articulated and experienced. In the context of the historical beginnings of fundamentalism, its other interpretation could thus be derived not so much from the fundamentalists' objection to the relativisation of the Revelation, but rather from the form in which this objection was expressed, characterised-at least in popular opinion - by such features as limited discursiveness or animosity towards interlocutors. This approach does not relate fundamentalism to the matter from which it emerges, but focuses on the mindset, way of acting, and goals pursued by fundamentalists. Consequently, it is not about the content based on which such an attitude develops, but the attitude itself that is decisive in determining whether we are dealing with fundamentalism or not. Defined on the ground of social sciences methodology, this other, formal understanding of fundamentalism, which stays in respect to proposals presented in Fundamentalism Project by Almond et al. (1995), recognises that first of all "what matters is not what people believe in, but how they defend their beliefs...and how they substantiate them" (Wnuk-Lipiński 2004, p. 273). In this approach, it is emphasised, therefore, that fundamentalism is an attitude.

\section{Characteristics of a Fundamentalist Attitude}

Considering fundamentalism as an attitude means understanding it as a way of approaching the world, a way of "evaluating" reality. This evaluation, according to the findings of social psychology, consists of three elements: cognitive, emotional (affective), and behavioural (Aronson et al. 1994). Consequently, fundamentalism understood as an attitude entails that fundamentalists primarily differ from the "rest of the world" by a specific way of thinking (a "fundamentalist mindset") which then determines the trajectories of a fundamentalist approach to the world, both emotionally and behaviourally. Such an understanding of fundamentalism would seem to be rather useful in the perspective of political science research.

\subsection{Cognitive Aspects}

A striking feature in the presented studies of fundamentalist groups and in the works of their founders is their sense of possessing, that is of having a complete understanding, of truth. Steven Bruce calls it a sense of "certainty" (Bruce 2000, p. 15). For example, in the theory of Sajjid Kutb, a leading ideologist of the Muslim Brotherhood, power originally belongs exclusively to God, who designed the right vision of the world. However, since God does not wield his power directly, in real life it should be held by those who have discovered and properly understood this truth. The "knowing" is embodied by warrior monks, who are the only bearers of truth (Was 2006). They are an elite in the proper sense of the word: the only competent subjects who define social and individual good. Bassam Tibi points out that such an attitude, with its characteristic intellectual absolutism, represents an important trait of 
fundamentalists who rule out any critical reflection on their own views (Tibi 1997). Ultimately, every decision and determination made by the "enlightened" is, as it were, sanctioned by God. For the record, this does not only apply to fundamentalist Muslim groups. For example, Karen Armstrong points to the intellectual absolutism of Christian fundamentalists. In this context, she refers to Carl McIntire, founder of the Bible Presbyterian Church in the USA, who radically condemned Christians who "did not subscribe to his theology" (Armstrong 2000, p. 216). A similar trait of fundamentalism has been identified in the Hindu tradition by Piotr Kłodkowski who, like Eric Hobsbawm, points out that Hindu fundamentalism represents "a contemporary interpretation of the ancient religion" (Kłodkowski 2006, pp. 425-26), linked to an ethnically understood national idea. It is not present in the Vedas themselves, but rather in their contemporary interpreters. The claim to truth, which is in fact a claim to inerrancy, should therefore be considered the first element of a fundamentalist mindset. Let us note that the truth professed by religious fundamentalists may radically differ, and its sources may just as well be the Vedas, the Quran, or the Bible. Irrespective of the material from which fundamentalism develops, it is always based on the fundamentalists' belief that they have achieved, so to speak, epistemic fullness, the only correct understanding of the Revelation and of God's will for people here and now.

A consequence of this attitude to truth is-however paradoxical as it may seem-an ambivalent stance on orthodoxy. As pointed out by scholars of fundamentalism, a fundamentalist does not embrace his religious tradition as a whole. Quite on the contrary, he only upholds those fragments that he accepts himself and which make him stand out from the "mainstream." In the case of Sajjid Kutb, mentioned above, this can be seen, for instance, in the special role played by the notion of tali'a, i.e., the need for a select avant-garde of crusading missionaries and emphasis on the category of jihad, which was not as significant in the traditional interpretation of Islam. This selectiveness of interpretation is in fact a reconstruction and a transformation of religious tradition (Jansen 1997). Fundamentalists are not concerned about faithful observance of orthodoxy. Oppositely, "they thrive by demarching themselves from others within their own faith-tradition" (Harrison 2008, p. 9). In a sense, they are the ones who create the "true" doctrine, selectively choosing from their religion that which is submitted to politicisation and absolutisation (Tibi 1997, p. 152). The selectiveness of a fundamentalist affects not only his religious (or ideological) tradition, but also the world he rejects. Bassam Tibi describes this process while referring to the example of Islamic fundamentalism: "the bisection of modern civilization stems from the desire of its islamisation by instrumentally adopting its material achievements, while at the same time unconditionally rejecting its fundamental man-centered view of the world...fundamentalists are not traditionalists ... they are against modern civilization, but they are not against its instrumental, that is to say, technical and scientific achievements. Quite on the contrary: they want to understand them in order to be able to better fight against their enemies" (Tibi 1997, pp. 35, 43). The airplane attack on the World Trade Center in 2001 seems to be a particularly dramatic evidence of this kind of logic, which currently can be observed in contemporary Islamists, bred on Kutb's writings, believing themselves to be the just ones who stand up (through jihad) against the unjust ones (e.g., the political leaders of the countries they operate in) (Haynes 2010, p. 165).

The belief in their own inerrancy in a way forces fundamentalists to adopt a black-and-white view of the world. As pointed out by Edmund Wnuk-Lipiński, irrespective of the grounds on which fundamentalism develops, it is always characterised by the conviction that "the part of the world which is outside of the fundamentalist movement is contaminated, sinful, and doomed to condemnation. Only within the world controlled by the fundamentalist movement can there be spiritual purity, truth, and good" (Wnuk-Lipiński 2004, p. 278). Consequently, in the logic of religious fundamentalists researchers see a reflection of the Manichean approach to reality where the forces of darkness (the world) are confronted by the forces of light (fundamentalists) (Bruce 2000).

\subsection{Affective and Behavioural Aspects}

The elements of a fundamentalist mindset described above (absolutism, selectiveness, Manicheism) translate into fundamentalist emotions and behaviours. It is characteristic that in almost all works 
on fundamentalism, the term is defined by what it repudiates (Gellner 1992; Bruce 2000). Thus, fundamentalism (e.g., in the case of Islamic or Christian fundamentalism) is described as a reaction to the modern world and the processes of modernisation and secularisation (Was 2006). In the case of Hindu fundamentalism, a sense of threat from other religious traditions (Islam or Christianity) is emphasised (Kłodkowski 2006). On the affective level, fundamentalists would thus be characterised by a sense of threat (fear) and by opposition, sometimes developing into hostility, to what is recognised as alien and standing in contradiction to the truth they possess about the right arrangement of human affairs (Haynes 2010; Harrison 2008). At the same time, fundamentalism-in all its varieties-helps restore a sense of security and commitment within one's own group, generating also high social control. Since the group of fundamentalists is the only bearer of truth which enables the introduction of an ideal order, those who belong to it truly feel they are fortune's favourites-God's avant-garde (Hallermann et al. 2019, p. 105f).

This specific emotional polarisation connected with the cognitive perspective described above, forces them, on the behavioural level, into activism in an attempt to change the world in accordance with their own views. A religious fundamentalist who believes that he possesses knowledge about the appropriate religious, social, and political order expected by God, and who objects to the actual condition of the world, puts himself in a position of both a prophet and a king. He reveals the "divine ideal" and feels responsible for its implementation. Therefore, he does in fact want the Messianic promises to be fulfilled in this world and strives to make the Kingdom of God arrive here on earth. Jonatan Jansen adds that "in such a Kingdom the literal truth of the revealed divine book will be a minor, self-evident detail" (Jansen 1997, p. 6). This somewhat sarcastic comment is very significant. A fundamentalist-as previously mentioned-is not an "orthodox" by nature. On the contrary, almost by definition he (re)defines the doctrine. And the purpose of this reinterpretation is to make the expected order come true in this world. Whether we are dealing with Islamic or Hindu fundamentalism, the striking fact is that a fundamentalist is first concerned not with what is "up above" but with what is "down below." In this sense, it is said, for example, that "Islamic fundamentalism is both fully politics and fully religion." (Kłodkowski 2006, p. 99; cf. Tibi 1997). Similarly, it would be difficult to separate the spiritual and the political dimensions in Hindu fundamentalism (Kłodkowski 2006, p. 415). Transformation of the world, commitment to making the ideal world come true, is the proper goal of fundamentalists whose efforts are always marked by a trait of utopia. Consequently, on the one hand, fundamentalists are prepared to reject anything they recognise as "alien," even if this means universal values.

Perceiving themselves as "chosen group," God's avant-garde, means also that fundamentalists "believe that it is essential to the religious integrity that they distance themselves from those who have been deemed to have strayed from the one and only correct form of faith. Thus, fundamentalist groups, irrespective of their religious tradition, tend to form exclusive communities within which only those who share their beliefs and their lifestyle are welcome" (Harrison 2008, p. 9). Such an approach reduces their ability to establish alliances almost to zero (Wnuk-Lipiński 2004, p. 280).

The above brief outline of the aspects of a fundamentalist attitude based on analyses and studies of religious fundamentalism plainly shows that it is the formal approach to fundamentalism (focused on the characteristic features of the attitude rather than any particular views) that makes this notion sufficiently clear to be useful in analyses of social and political phenomena.

\section{Secular Fundamentalism}

When fundamentalism is treated as an attitude, this suggests, from the theoretical perspective, that the quite widespread conviction about the exclusively religious nature of fundamentalism needs to be corrected. Even though the analyses presented above, based on extensive literature on the subject, were focused on the religious forms of the fundamentalist attitude, it can hardly be concluded that any of its characteristic features (for example, a selective way of thinking, or a desire to change the world in accordance with one's own standards) are limited only to the religious attitude. Moreover, 
fundamentalists can see a threat in both secular and religious stances. In view of the above conclusions, we need to ask about the existence of secular fundamentalisms. If the theory of fundamentalism outlined above is correct, the fundamentalist approach should then be also possible to detect on secular grounds.

\subsection{Classical and Contemporary Manifestations of Secular Fundamentalism}

A review of studies on the political phenomena of the 20th and the 21st century, including in particular secular religions (Aron 1962; Voegelin 2000), leaves practically no doubt that the above statement is substantiated. One of the most well-respected Polish sociologists, Edmund Wnuk-Lipiński, demonstrated the legitimacy of considering communism as a form of secular fundamentalism. In Świat międzyepoki, he showed that the communist logic includes all the symptoms of a fundamentalist attitude: the belief in possessing the truth, a selective approach to "sacred texts," rebellion against the existing order coupled with a commitment to creating an ideal world, worship of the leader, and hatred of the "enemies of the system," activism in striving to change the world, etc. (Wnuk-Lipiński 2004, pp. 281-84). It is characteristic that already in 1917 Lenin believed that his "prime task is to re-establish what Marx really taught" (Lenin 1918), and therefore-in a typically fundamentalist way-demanded that everyone should accept his own as the only right interpretation of canonical texts, radically distancing himself from those who-also drawing on the teachings of Marx-were not revolutionary enough, in his opinion, and in fact falsified Marxism by "deceiving the people." For even though the writings of the author of Das Kapital were the communists' "sacred" texts, they were not so in every interpretation. The right one, just like in the case of the interpretation of Islam by the ideologists of the Muslim Brotherhood, was that of the current leader and his entourage.

In fact, as has been pointed out by Eric Voegelin, who demonstrated the gnostic sources of Marx's thought, Marxism itself was a theory aimed at "incarnating the logos in the world by means of revolutionary human action" (Voegelin 1975, p. 275) thus representing a specific, fundamentalist type of mindset. Voegelin points out that Marx transformed Hegel's contemplative gnosis into practical action, becoming "a Paraclete in the best medieval, sectarian style, a man in whom the logos had become incarnate and through whose action in the world mankind at large would become the vessel of the logos" (Voegelin 1975, p. 276). Without going into a more detailed discussion of a fundamentalist character of "political religions," insightfully analysed inter alia in the classical works of Erich Voegelin (2000) or Raymond Aron (1962), it is worth noting, however, that secular fundamentalist tendencies are found not only in "total phenomena."

John Gray points out that radical Islamists are essentially not very different from communists or neoliberals in terms of the structure of their mindset. He says, "In the new world as envisaged by $\mathrm{Al}$ Qaeda power and conflict have disappeared. This is a figment of the revolutionary imagination, not a prescription for a viable modern society; but in this the new world envisioned by Al Qaeda is no different from the fantasies projected by Marx and Bakunin, by Lenin and Mao, and by the neoliberal evangelists who so recently announced the end of history" (Gray 2007, p. 4). The same thought can also be found in the writings of Agnieszka Kołakowska, who describes several examples illustrating how the ideologisation of certain categories of contemporary political discourse due to political correctness in fact hinders any rational debate. She says that a good exemplification of the "anti-empirical, anti-rational, and anti-scientific approach is the issue of 'globalisation'": the "evil" of globalisation, just like the "good" of sustained development, is a kind of dogma which "must not be questioned" (Kołakowska 2010, pp. 21-24). The conviction that one possesses the truth and the ultimate knowledge of the proper order of things results - in accordance with the fundamentalist paradigm - in open animosity of the "politically correct" to those who think otherwise, and in a radical suppression of anyone who questions "the one and only truth." As pointed out by Matthieu Bock-Cote, "progressivism inherently includes the temptation of fanaticism and paves the way for the practice of presenting 'reactionaries' as public enemies, as enemies of the human race...it sanctions intolerance by justifying it with noble motives" (Bock-Cote 2017, p. 302). 
The question is whether the above claims are sufficiently substantiated-whether in the aspirations of Karl Marx to finally set the course of history towards salvation, and in the "politically correct" activities aimed at silencing certain views, ideas, or groups, a similar logic can be found. In other words, can it be demonstrated that in both cases we are dealing with a belief in the "inerrancy" of the elite who possess the formula for an ideal order; an exclusive patent on knowledge of the proper form and sense of socio-political institutions and relations, i.e., with an analogous fundamentalist potential.

\subsection{Fundamentalism as an Element of Modern Politics}

Studying the dispute accompanying modern politics, in his book entitled A Conflict of Visions. Ideological Origins of Political Struggles Thomas Sowell (2007) takes as his starting point the experience of two revolutions: American and French. The former brought about the formation of a constrained government, which respected the presence of religion in the public sphere; the latter, being in a way a harbinger of the totalitarianisms of the 20th century, organised an open war against Christianity combined with a state terror, which was perceived as-let us quote Robespierre- "a consequence of the general principle of democracy applied to country's most urgent needs" (Carr 1951, p. 154).

Where did this difference come from? Sowell believes it had its source in two diametrically different metapolitical views, understood as ideal types in Weber's sense: constrained and unconstrained (Sowell 2007). The former attempts to reconcile conflicting interests and opinions about what may be considered as social good, while the latter strives to implement a knowable and identifiable social good as an overriding value (for example, the Marxist ideal of a classless society) (Vanberg 1987, p. 547). The former, referring to the intuition that civilisation is but a thin layer superimposed over layers of barbarism, sees "postponing the end" as the "basic structure of all human politics," which seems to be here "a watchful keeping in check of those tendencies which are conducive to exploding the 'original chaos'" (Spaemann 2012, p. 275). The latter, inspired by the optimism of the Enlightenment, sees politics as a tool of constant progress: in a Promethean blast it wants to build a paradise on earth. While in the former perspective, social experiments may threaten the existence of humankind, in the latter there is no risk involved, since-behind man's back, so to say—an invisible hand will lead human history to a happy ending anyway. In the former perspective, the goal is to "postpone the end," while in the numerous versions of the latter-to "prepone" it.

A different perception and moderation of the dynamics of social processes results, according to Sowell, from a different concept of the political reason in the advocates of both visions. The proponents of the unconstrained vision believe that it is possible to find a rational answer to all problems and challenges, if only the forces of intelligence and of virtue could be made to prevail over ignorance and wickedness (Berlin 1950, pp. 351-85). Consequently, the unconstrained vision employs intellectual reflection to look for a solution of the political problem and establish some form of the ideal order. Every social change which is a step towards achieving this desired ideal should be preferred, no matter the cost (Sowell 2007, p. 29). In the course of the teleological process leading to social change, it is conditionally permissible to use violence, characteristic of revolutionary politics.

In the constrained vision, reason is treated with much more skepticism. Knowledge is conceived first of all as social experience, passed on in non-articulated forms of traditions, customs, habits, sentiments, feelings and behaviours; it is the everyday experience of people, succeeding in the Darwinian contest between that which works and that which does not. Consequently, knowledge is broadly accessible, but always shared. The advocates of constrained vision strongly believe that individual reason is much too insufficient to capture the diversity and take the right decisions. This gives rise to a politics of cautious evolution: since systemic rationality is more reliable than individual rationality, a reformer will respect the established customs and prejudices of the people, yet "will not disdain to ameliorate the wrong" (Sowell 2007, p. 27). A key category for the advocates of this vision is the compromise (trade-off) developed within the framework of systemic processes. One might say that imperfection is here understood as a perfect social solution. 
The belief that knowledge is an element which results in qualitative differences between people leads the advocates of an unconstrained vision to the conclusion that citizens of narrow horizons should submit to the leadership of the elites who cultivate the mind: philosophers or qualified experts. The special role of "the thinking people" or the "most enlightened and the best" was, according to Sowell (2007, p. 44), a central theme of the unconstrained vision for centuries. Consequently, its advocates placing decision-making rights in the hands of the "avant-garde" (social elite) whose members are, for some reason, more competent in identifying the knowable and achievable good. They are guaranteed — though it is not clear how—a privileged access to resources of virtue and reason. They act as a "surrogate" of the society, leading it toward "ever-higher levels of understanding and practice ... pending the eventual progress of mankind to the point where all can make social decisions" (Sowell 2007, p. 110). As pointed out by Bock-Cote, "the one who knows what a perfect society is, does not engage in political debates but multiplies educational efforts, and may, if necessary, resort to violence or censorship to prevent the expression of political opinions which challenge his idea of utopia or the meaning of history" (Bock-Cote 2017, p. 302).

Without entering into an in-depth analysis of unconstrained politics (cf. Gierycz 2017), it should be emphasised that Sowell's analysis leads us to the conclusion that the fundamentalist potential is deeply ingrained in one of the two ways of thinking about politics which are characteristic of modern Europe. It appears that the concept of unconstrained politics coincides with an observation made by John Paul II in Centesimus Annus: "When people think they possess the secret of a perfect social organization which makes evil impossible, they also think that they can use any means, including violence and deceit, in order to bring that organization into being" (John Paul II 1991, no. 25). Such an approach, the Pope points out, in fact turns politics into a "secular religion," "which operates under the illusion of creating paradise in this world." Evidently, it is not a coincidence that such kind of logic emerges when religion is negated, initiating - together with the French Revolution - the secularisation processes in Europe. It seems that although "the secularist and the sceptic have denounced Christianity first and foremost, because of its encouragement of fanaticism," Chesterton rightly noted that "religion can be swept out of the matter altogether, and still there are philosophical and ethical theories which can produce fanaticism enough to fill the world" (Chesterton 2017, p. 319).

Since at its roots secular fundamentalism is linked to the hope of a perfect world and is profoundly inherent to the modern understanding of politics in Europe, two questions need to be considered: (1) whether it is not the case that-grating the ambivalent role of religion in the development of fundamentalism, as discussed above (particularly in Section 2)-it is precisely (if not only) religion that represents an effective, "systemic" safeguard against such tendencies; (2) what features of religion make it a substratum for fundamentalism, and which of its characteristics make it a hedge, or a natural safeguard against fundamentalist tendencies.

\section{Secularisation and Fundamentalism}

When discussing essential factors contributing to the development of religious fundamentalisms, literature on the subject usually refers to the threat of modernisation and related secularisation, i.e., departure from the traditional, religious models and values (Harrison 2008; Armstrong 2004). This is to a large extent true, as it was shown, in the reference to the beginnings of the fundamentalist movement in the USA. The first fundamentalist Islamic group, the Muslim Brotherhood, similarly emerged in reaction to the rapid westernisation of Egypt as a result of British colonisation. Thus, it is claimed that fundamentalism is one of the side-effects of secularisation processes, a "rage" of religiousness, so to speak. In accordance with this hypothesis, fundamentalism is supposed to be a response (reaction) of religious people to religion being denied the right to a presence in the public space (Bruce 2000, p. 101), a "revenge of God" (Kepel 1994). The example of the Muslim Brotherhood, which identifies modernisation with secularisation and consequently looks for the sources of all social, economic and political crises in the Muslims' departure from the precepts of their faith, indicates that this hypothesis has a significant explanatory value. 
Nonetheless, it is also worth noting that in contemporary times it is true mostly when applied to the relationship between the West and non-Western cultures. Secularisation-being an essentially European, and to some extent Western, phenomenon-does not cause a special "irascibleness" of the religion prevailing in Western hemisphere. This is triggered, if at all, in different cultures, mainly Islam.

This does not undermine the significance of the hypothesis which sees in secularisation an important cause or context of fundamentalism in the West, for there is a deeper layer to it. As noted above, in the age of modernity, secular fundamentalisms have developed on an unprecedented scale, leaving their imprint in the modern era not only as political religions, but also as a deep-running current of understanding politics in the spirit of unconstraint. It is therefore worth considering whether this hypothesis does not also provide us with an answer regarding the sources of Western, secular fundamentalism.

When looking for what represents the novum in the intellectual climate of modernity, one can hardly ignore the radically secularising, great new narration initiated during the Enlightenment which replaced the hitherto prevailing Christian narration. As noted by Joseph Ratzinger, "[t]he Enlightenment attempted to define the essential norms of morality while claiming that they would be valid etsi Deus non daretur, even if God did not exist" (Ratzinger 2005, p. 354). This reflection has led to the invention of a "secular public space" and a "secular state" as an area of "pure power" organised by man "as though God did not exist" (Mazurkiewicz and Gierycz 2016, p. 136). Consequently, the sacrum has been finally removed from its central, pivotal place which had organised social life (Casanova 1994, pp. 11-39).

Once Providence was forced into "retirement," in a process profoundly linked to the Enlightenment belief that once mankind entered its adulthood and all "dogmas and formulas" became expendable (Kant 1784), the legitimacy of the religious narration about eternal happiness and paradise was undermined. This did not, however, eradicate the very idea of a perfect order from social consciousness. On the contrary, the emerging modernity lives and breathes the idea of perfection, with a sense-clearly visible in the writings of the Enlightenment luminaries - that it is just "a step away" from achieving the state of perfection in human affairs. This new hope probably first appeared in the writings of Francis Bacon, for whom "the restoration of the lost 'Paradise' is no longer expected from faith, but from the newly discovered link between science and praxis" (Benedict XVI 2007, no. 17). In the course of transformations that followed in subsequent ages, the source of hope is shifted from science to scientifically designed politics that—as exemplified in Marx's flagship work—"recognizes the structure of history and society and thus points out the road towards revolution, towards all-encompassing change" (Benedict XVI 2007, no. 20).

The process of secularising Christian hope in the West thus opens a gateway, to use Eric Voegelin's expression, to the process of immamentising the eschaton; to an attempt-by definition doomed to failure - at making the ideal world come true in the here and now, and to ultimately destroy all evil. This entails a huge fundamentalist potential. As Krzysztof Dorosz rightly points out: "as long as the apocalyptic awareness is rooted in faith, God's sovereignty is respected, leaving it up to him to choose the time and place of intervention. Man is only supposed to wait. If, however, the apocalypse becomes secularized, or if it penetrates the imagination of religious activists who usurp for themselves the prerogatives of God himself, it becomes a real power in the world" (Dorosz 2010, p. 23). Naturally, the usurpation of God's prerogatives is possible first of all when the true God is removed from sight. In this perspective, one can clearly see that the process of secularisation doubly, so to say, weakens the dam against fundamentalism. Not only does it generate in non-Western cultures movements of "angry religiousness," but also, in regard to the secularised world, leaves room for claims that the ideal world may be made to come true in the here and now, thus contributing to the emergence of secular fundamentalist concepts. In other words, in consequence of making God irrelevant for the world, modernity creates perfect conditions for replacing the hope of God's kingdom with the hope of a kingdom of man. 
The above conclusion reveals the special, irreplaceable role of religion as a safeguard against fundamentalism. Whether we understand religion as a set of beliefs and practices, or as a relationship with God, it is a way, which starts, to cite Max Scheler, "from something absolutely holy" (Scheler 1921). Consequently, by its very nature it situates man's natural longing for "a radical improvement ... in the relationship to a supra-empirical Reality" (Kłoczowski 2004, p. 1064). The matter is of key importance, since this need for a "radical improvement, a salvation," as indicated by Kłoczowski (2004) or Zdybicka (2006), is an anthropological, inherent to the human condition, need. If we realise that fundamentalism involves an attempt at actualising eschatological hopes in the temporal world, we must conclude that only religion can provide a systemic hedge against their immanentisation and warrants keeping an eschatological distance. Unless it is immanentised, it will contribute to a constructive involvement in matters of this world. Let us note the social and political significance of Christianity, which "did not bring a message of social revolution like that of the ill-fated Spartacus, whose struggle led to so much bloodshed ... Jesus, who himself died on the Cross, brought something totally different: ... an encounter with a hope stronger than the sufferings of slavery, a hope which therefore transformed life and the world from within" (Benedict XVI 2007, no.4), which was demonstrated, for example, in the eradication of slavery in Europe.

Obviously, experience shows that not every religion can or even does perform such a role, and not in all circumstances. In view of the above comments which show fundamentalism as a problem of the specific mindset related to an immanentisation of messianic hopes, it appears that the key variables which are worth discussing here are (1) a religion's attitude to reason, and (2) its attitude to the temporal world.

\section{Reason, Religion, and Fundamentalism}

Some researchers investigating the phenomenon of fundamentalism believe that religion generates fundamentalism due to its inherent claim that it carries the absolute truth (Armstrong 2000). The absolutist claims of religion, including its conviction about the right order of things, would, in accordance with this hypothesis, generate a great fundamentalist potential in religions placing a great deal of emphasis on orthodoxy (dogmatics) and with strong centres of leadership. It would thus be present in religions characterised by monotheism and dogmatism, that is to say, Christianity, and Catholicism, Islam and Judaism in particular. Hinduism and Buddhism would be almost entirely free of it. On the face of it, this argument may seem quite convincing, since-as mentioned above-a key element of fundamentalism in the political sense is a fundamentalist mindset, a belief in possessing the absolute truth.

\subsection{Absolute Truth and Fundamentalism}

Political and religious reality advocates caution, however, in unquestioningly accepting the above hypothesis. Certainly, absolutist claims to the truth and a strict order of power may be conducive to fundamentalist attitudes. Nevertheless, the religion which most explicitly carries absolutist claims-Catholicism - is not a particularly fertile soil for fundamentalism in the political sense of the term, despite the strict Catholic dogmatics, its monotheism, a single leader who provides the ultimate and binding interpretation of the truths of faith (see the dogma of papal infallibility in matters of faith and morals), as well as the hierarchical structure of power and subordination. Meanwhile, in the soil of Islam of Hinduism the phenomenon of fundamentalism thrives and prospers, even though they are religions without single dogmatics (in the case of Hinduism, it is even problematic to use the term orthodoxy), lacking a leader or even a single body to interpret the faith, with a scattered organisation of the faithful, and thus—as is sometimes said-much more democratic (Zenderowski and Wysocki 2014; Harrison 2008). One must thus conclude that the existence of absolute truth, or, to be more precise, belief in the universal validity and applicability of particular truths does not necessarily result in a kind of political fundamentalism. 
The logic that identifies belief in the truth with fundamentalism is open to considerable theoretical doubt. If it were to be accepted, the term fundamentalist would have to be applied to all those who claim that their convictions are universally applicable-for example, the advocates of human rights, or scientists. The obvious absurdity of such a solution shows that linking fundamentalism only to the recognition of truth is problematic to say the least. It would mean that scientists-who are particularly committed to rationally substantiating their opinions and developing the understanding of the truth they discover-would be a model example of a fundamentalist mindset characterised by limited openness to discussion.

The above findings suggest that we should reject the thesis that belief in universal truths present in a religious message represents in itself grounds for fundamentalism in the political sense. They also reveal another factor which may affect the fundamentalist potential of religion. Instead of faith in absolute truth, the criterion might be the relationship between faith and reason. A hypothesis may be proposed that fertile soil for fundamentalism may be provided by religions which not only claim to carry a universal truth (which is a constitutive element of nearly all religions as well as secular convictions concerning outlook), but which do not necessarily link it with the order of reason, or which are irrational by their very nature, and so, as pointed out by Gilles Kepel (1994), eluding the logic of reason. A doctrine more open to the ratio, in light of this hypothesis, would be less susceptible to becoming a soil for the "fundamentalist mindset" than a doctrine which says that the will of God or gods is not related to the category of rationality.

The above hypothesis may explain why so few fundamentalists are bred by Catholicism, while they thrive in the world of Islam and Hinduism, for example. This issue was mentioned by Benedict XVI during his well-known address in Regensburg. Citing the Byzantine emperor Manuel II Paleologus, he pointed out that it was obvious for the Christian emperor that violence was incompatible with the nature of God and the nature of the soul. He stressed that "[ $t$ ]he decisive statement in this argument against violent conversion is this: not to act in accordance with reason is contrary to God's nature" (Benedict XVI 2006). Referring to the comment of Theodore Khoury, who pointed out that "[f]or the emperor, as a Byzantine shaped by Greek philosophy, this statement is self-evident," he showed what he believed to be a fundamental difference between the Christian tradition, where God is presented as Logos (word, reason), and the Muslim tradition, where God is not bound by the norms of human rationality. Only in this latter perspective it is possible to go so far as to state, as did Ibn Hazn, that "God is not bound even by his own word, and that nothing would oblige him to reveal the truth to us. Were it God's will, we would even have to practise idolatry" (Benedict XVI 2006).

Christianity, as a religion of Logos (cf. J 1), did not encounter the Greek thought by chance, as pointed out by Benedict XVI who says: "The vision of Saint Paul, who saw the roads to Asia barred and in a dream saw a Macedonian man plead with him: 'Come over to Macedonia and help us!' (cf. Acts 16:6-10) — this vision can be interpreted as a 'distillation' of the intrinsic necessity of a rapprochement between Biblical faith and Greek inquiry" (Benedict XVI 2006). The originality of the work of Church Fathers consisted in the fact that they "fully welcomed reason which was open to the absolute, and they infused it with the richness drawn from Revelation" (John Paul II 1997, no. 41). From the perspective of the Catholic Church, this was not merely a meeting of cultures, but a metaphysical encounter; as John Paul II put it: a meeting "of creature and Creator." In its result, both faith and reason could rise, so to say, to a higher level: faith could build on reason, in which it found "a solid foundation for the perception of being, of the transcendent and of the absolute," as reason illuminated by faith is "set free from the fragility and limitations ... and finds the strength required to rise to the knowledge of the Triune God" (John Paul II 1997, no. 41 and 43). As a consequence of this encounter, it is not possible in the light of the Catholic doctrine to effectively separate faith from reason. This was most emphatically stated already by Saint Anselm, who wrote, "as the right order requires us to believe the deep things of Christian faith before we undertake to discuss them by reason; so to my mind it appears a neglect if, after we are established in the faith, we do not seek to understand what we believe" (Anselm of Canterbury 2005). 
This opening of faith to reason or, in fact, this fusion of faith and reason in the Catholic tradition also leads to a particular understanding of truth itself. Recognising the immutability of truth, the Catholic Church believes that truth is not static, it is not something that "we hold in our hands." Rather, it is seen as a gift from God, who keeps revealing himself to us. Consequently, its understanding is subject to continuous development, even though it is not subject to change. This conviction, present already in the first centuries of Christianity, is reflected well in a statement made by Saint Vincent, who explained, in the 5th century A.D., that "progress requires that the subject be enlarged in itself, alteration, that it be transformed into something else" (Vincent of Lerins 1894, no. 54). He therefore compared faithfulness to the truth of Revelation to a living organism, "which, though in process of years it is developed and attains its full size, yet remains still the same" (Vincent of Lerins 1894, no. 55). A similar statement was made by Vladimir Solovyov, who emphasised on the grounds of the Orthodox tradition: "Just at it would be foolish, not seeing the trunk or branches, leaves or flowers in the seed, to conclude that all of this is an artificial, external addition rather than a growth from the seed itself, and therefore to reject the entire future tree in order to only keep the seed; so it would be equally foolish to reject more sophisticated, that is to say, more developed forms of God's grace in the Church and to stubbornly seek to return to the form of the early Christian communities" (Solovyov 1988, p. 96).

It is worth stressing here that the synthesis of Biblical faith and Hellenic rationality, characteristic of Christianity, is manifested in different ways in its various currents. On the grounds of Christianity - together with Duns Scotus — the concept of voluntarism appeared and was later developed by Wilhelm Ockham, among others. It finally led to the claim that "we can only know God's voluntas ordinata. Beyond this is the realm of God's freedom, in virtue of which he could have done the opposite of everything he has actually done ... God's transcendence and otherness are so exalted that our reason, our sense of the true and good, are no longer an authentic mirror of God, whose deepest possibilities remain eternally unattainable and hidden behind his actual decisions" (Benedict XVI 2006). In Catholicism, this stance has never been accepted (Ockham himself was excommunicated by John XXII), and the Church has upheld its unequivocal belief in the "rationality" of God-the Logos. Ockham's logic has, however, left a significant mark on the Protestant tradition, which-through Martin Luther-embraces to a large extent the voluntarist view of God.

Educated in the spirit of nominalism, Luther radically dissented from Aristotle's philosophy, claiming that "he is to theology what darkness is to light. His ethics is the worst enemy of grace" (Maritain 1928, p. 15). In fact, he dissented from philosophy at large, claiming that reason was incompatible with faith (Maritain 1928, p. 16). Consequently, in practically all of its currents, Protestantism has criticised "philosophised theology" and-to a large extent deliberately-began the process of de-Hellenising Christianity (Szulakiewicz 2005, p. 184). As pointed out by Sławomir Springer, "Barth's battle against natural theology was a closure of the criticism, mounting since the times of F. Schleiermacher and Ritschl, which Evangelical theologians had raised against the traditional philosophical doctrine of God and against its use in the sphere of theology" (Springer 2010, p. 43). Worth mentioning is also the work of Adolf von Harnack, whose theology undermined the idea of dogma, seeing in it "the Greek spirit adopted by Christianity" (Szulakiewicz 2005, p. 186). Such an approach is a direct legacy of Luther, who, according to Maritain, claimed that "the use of reason in matters of faith, the claim to establish a coherent science of dogma ... by reasoning and the use of philosophy, in short, theology ... is an abominable scandal" (Maritain 1928, p. 16). We might add that even in those currents which do not advocate a liberal interpretation of the Scripture, Protestantism is marked by a "de-Hellenised" understanding of God. Let us take Søren Kierkegaard, for example, for whom "God is above morality" (Iwaszkiewicz 1972, p. XXXI) or, to refer to a less intellectually sophisticated interpretation of Protestantism, some of its American denominations marked by "an extremely anti-intellectual approach, only looking for an excuse to ... create a front between theology and science" (Życiński 1998, p. 24).

Once we recognise the diversity in approaches to rationality within Christianity, we can better understand the radical difference in the understanding of God we encounter in the context of Islam. 
The difference is already manifest in the fact that the Quran—as pointed out by Norman Daniel—a book believed to be dictated by Allah, has a status similar not so much to that of the Bible in Christianity, but to that of Jesus himself (Weigel 2009, p. 183). While in Christian tradition understanding of Revelation does not end with the letter of the Scripture (though, obviously, it may not contradict it), the Quran is more of a final and definitive decree of God's truth. This significantly contributes to the development of a belief in "possessing the truth," and-ultimately—the usurpation of "God's prerogatives" since its full and literal message has been placed "in our hands."

It seems of key importance, however, that in the Quran the (early) surahs which talk about mercy, peace, and tolerance, are found directly alongside the (later) ones which "advocate violence-violence directed against those who do not share the Muslim faith" (Kłodkowski 2006, p. 105). Consequently, although it is possible to claim that the Quran "accepts with approval both religious pluralism and diversity" (Ayoub 2007), according to the rule of abrogation (Sulkowski 2018) and in view of the status enjoyed by the Quran, the logic of Islam enables the adoption of a voluntarist view of God. In the Muslim context, today's jihadists or the ISIS fighters seem to be the faithful heirs of Ibn Hazn. As pointed out by George Weigel, the essence of their logic lies precisely in the identification of God as Absolute Will. Consequently, "jihadists are, within their own frame of reference, justified in believing that God can command anything-even the irrational. And so ... they believe that the murder of innocents is not simply morally acceptable, but morally required, if such murders advance the cause of Islam" (Weigel 2009, p. 59). In fact, the problem runs deeper, although it would be hard to challenge their interpretation of Islam based on the revelation of the Quran since it does not necessarily link God's will with the categories of human rationality.

A different kind of source for a voluntarist view of God is to be found in Hindu tradition. As it is well known, Hinduism is a religion of rich mythology, without consistent doctrine or even scriptural canon (Chiriyankadath 2010), which also means that is "paradoxical—often self-contradicting-in a number of ways on its foundational concept of God" (Zenderowski and Wysocki 2014, p. 8). Hindu mythology is understood "to have developed the idea of a divine triad in the earliest times that governs over everything. The triad emerged as an influence of the solar cults of India and had different deities in it during the Vedic Age. However, in the last thousand years of the Indian religious tradition, the universally governing triad has consisted of Brahma, Viśnū, and Siva- 'the creator', 'the cherisher,' and 'the destroyer.' These three persons of the Godhead are coequal and are therefore worshipped as three faces of the same God. The Sanskrit expression for the Hindu triad is Tri Mūrtī Eko Deva, 'three faces, one God"' (Waqas 2015, pp. 9-10). The very fact that God could be at the same time a creator and a destroyer shows the challenge present in Hindu tradition to link God's will with the categories of human rationality, which inter alia refers to the law of no contradiction.

Even without going into detailed analysis of every religious tradition, the remarks above prove a need for critical reflection on the relation between belief in the absolute truth and fundamentalism in the political sense of that term. It seems that fertile soil for fundamentalism tends to be provided by religions which do not necessarily link their truths with the order of reason, grounding, in different ways, a voluntarist view of God rather than by belief in universal truth. Theory focused on relation between credo and ratio much better explains empirical observations, which suggests that the fundamentalist potential of Islam or Hinduism is profoundly higher than that of Christianity, and of Catholicism in particular.

\subsection{The Temporal Aspirations of Religion}

The reflection about the significance of the attitude to rationality for the emergence of fundamentalist movements needs an additional note, however. If we assume that the content of fundamentalism in all of its varieties is the idea of God's power, understood not in the perspective of eternity or the deep sense of historical events, but as actualised directly and fully in "this world," then the issue of key importance for the relationship between religion and fundamentalism is the relationship between religion and politics. It may thus be hypothesised that fertile soil for the development of 
fundamentalism is provided by religious doctrines which create an ideal, a utopia of social and political relations, supported by divine authority. At the same time, since at its sources fundamentalism is related to a hope of establishing a perfect world, a religion which introduces an eschatological distance to the temporal world will become a natural buffer against fundamentalist tendencies.

The difference between Islam and Christianity could be used as a case study. One specific feature of Islam is that it regularises the organisation of society and state (Zenderowski 2014). The dichotomy of regnum and sacerdotium, so crucial in the history of Western Christendom, has no equivalence there (Sulkowski 2018). Consequently, politics that represent a direct answer to religious commandments are, in a way, a natural form of the political. Without violating the structure of the relationship between religion and politics provided for in the Quran, it may legitimately be treated as a tool in creating a "model" world. Politics and religion are thus fused to a large extent through eschatology: politics may be treated as a tool for creating an ideal social and political order, contained in the religious formulas of the Quran and the tradition.

It is worth emphasising that such a stance is not only found in radical Islam. On the contrary, also liberal Muslim ideologists, who criticise traditional ulemas, object to the separation of the spiritual from the temporal. For example, for Mehdi Bazargan, one of the liberal leaders of the revolution in Iran, it was obvious that "there is no frontier between religion and politics. Religion must control and inspire politics, and not the contrary" (Keddie 2003, p. 199). Consequently, he criticises Christianity for being "unable to give believers directives for practical, social, and political life," referring them to "philosophic-political idols" (liberalism, socialism, etc.), "which Islam does not need, as it is a complete religion" (Keddie 2003, p. 199). A complete religion-for Islamic liberals, too-is a comprehensive one, providing solutions that are both temporal and eternal, whose natural environment is religious and political unity. Aware of this specificity of Islam, some scholars even propose that fundamentalism is inherent to Islam (Kłodkowski 2006, pp. 99-101).

Christianity, as Bazargan rightly points out, perceives the relationship between religion and politics differently. The Church, carrying internally the memory of Christ's death on a verdict issued by a governor of the Roman Emperor, as well as Christ distancing himself on many occasions from temporal power, believes that the Kingdom of God, or an ideal order, should not be expected or attempted here on earth. Consequently, the Church perceives identification of the state and religion as a temptation which, if succumbed to, would be as harmful to the state as it would be to religion (Mazurkiewicz 2012). In this perspective, it is easy to understand why, in their reflection on law, "Christian theologians aligned themselves against the religious law associated with polytheism and on the side of philosophy, and that they acknowledged reason and nature in their interrelation as the universally valid source of law."(Benedict XVI 2011) It is not an exaggeration, therefore, to say that the central idea of modern democracies, namely the idea of the rule of law, is an outcome of the supra-religious approach, developed on Christian grounds, to the foundations of legal order (Gierycz 2012).

The Christian approach to politics is anchored in the belief that man, created in the likeness and image of God, participates in God's wisdom by his very nature through reason. By virtue of this participation, he is able to recognise and strive towards objective good (Thomas 1947, p. 2270). This participation does not depend on faith (cf. Romans 2, 14-15) but results from the very nature of man - within himself, he discovers an inner law which is "natural" to him, inherent to the human condition (John Paul II 1993, no. 43).

The reference to natural law does not make religion irrelevant. Christian tradition is fully aware, as expressed already by Cicero (The Republic), of man's freedom in violating or obliterating this law within himself. As Thomas Aquinas says, although the "natural law, in the abstract, can nowise be blotted out from men's hearts," "it is blotted out in the case of a particular action, in so far as reason is hindered from applying the general principle to a particular point of practice, on account of concupiscence or some other passion ... by evil persuasions ... or by vicious customs and corrupt habits....and even unnatural vices" (Thomas 1947, p. 2308). Christianity is also aware that God is the one who should be asked about good (see Mark 10:17-27); that there is a need of higher that human 
being authority to resolve moral dilemmas; that revelation brings knowledge about what is the good proper to man and is the point of reference for properly forming one's conscience. Thus, emphasising that the state does not "create" good, "Christianity maintains that the objective norms governing right action are accessible to reason, prescinding from the content of revelation. According to this understanding, the role of religion in political debate is not so much to supply these norms, as if they could not be known by non-believers-still less to propose concrete political solutions, which would lie altogether outside the competence of religion - but rather to help purify and shed light upon the application of reason to the discovery of objective moral principles" (Benedict XVI 2010). Such a role of Christianity, pointed out in similar ways by secular thinkers (Habermas 2005; Perra 2005), shows that in the case of Christianity, religion is not a political factor but rather "external" to politics and a source which the political community may draw on for moral truth. Consequently, politics and religion within the Christian tradition are linked not by eschatology, but by ethics (Gierycz 2012; Mazurkiewicz 2007). Religion thus becomes a buffer that safeguards respect for human dignity in the political order.

\section{Conclusions}

The above analyses have essentially, though not all in the same way, confirmed the legitimacy of the three hypotheses made at the outset.

From the perspective of political science, it seems no longer possible to maintain that fundamentalism is a strictly religious phenomenon. Both the studies into religious fundamentalism analysed and documented manifestations of secular fundamentalism lead to the conclusion that it is simply a specific way of thinking and acting which may develop and thrive just as well in secular as in religious soil. Its specific feature is the aspiration, anchored in an absolutist, selective and Manichean mindset, to establish an ideal order, which even justifies the use of violence. Fundamentalism as such is not necessarily related to religion, and-as demonstrated by history—has also thrived in atheist and anti-religious systems.

Additionally, the second hypothesis, namely that secularisation contributes to both secular and religious fundamentalist tendencies, has proved to be well-substantiated. As has been demonstrated, while secularisation in the West generates reactions of angry religiousness in other cultures (e.g., Islam or Hinduism), in the context of Western culture it contributes to the development of secular fundamentalisms, supporting the idea of unconstrained politics, and thus the hope for immanentising salvation, too. In this aspect, the analyses presented above suggest that it is necessary to broaden the meaning of the traditional modernisation hypothesis which considers only religious fundamentalism to be a reaction to the process of secularisation.

With regards to the third hypothesis, it should be noted that-on the theoretical level一the above analyses have confirmed that religion potentially represents a unique safeguard against fundamentalism, with practically nothing to substitute for it. By providing an ethical grounding for the political order, particularly by warranting an eschatological distance from political issues, it prevents the kingdom of man being confused with the kingdom of God, thus discarding the fundamentalist logic at its very roots. At the same time, the analyses have revealed two key conditions which must be satisfied if a religion is to provide such a barrier: firstly, it must understand itself as a rational religion; and secondly, it must clearly distinguish spiritual from secular power. Consequently, the analyses have shown that, regarding the actual role of religion as a safeguard against fundamentalism, the hypothesis is a medium-range claim, explaining in the contemporary context-in relation to the major religious traditions-first of all the role of Christianity, especially Catholicism, with respect to fundamentalist tendencies. In fact, the religions of the world are religions of reason to a very different degree, and they are often not interested in introducing a separation between spiritual and secular power. The above analyses have shown that, in the context of Islam where the vision of God is largely arbitrary and unpredictable, and where religion and politics are closely intertwined, fundamentalism could be, essentially, a natural product of the religious tradition. In the context of Western Christianity, where the separation between secular and spiritual power is—generally—an obvious principle, a different 
attitude to reason in religion may explain the higher fundamentalist potential of Protestantism than of Catholicism.

Funding: This research received no external funding.

Conflicts of Interest: The author declares no conflict of interest.

\section{References}

Almond, Gabriel A., Emmanuel Sivan, and R. Scott Apleby. 1995. Fundamentalism: Genus and Species. In Fundamentalism Comprehended. Edited by Martin E. Marty and R. Scott Appleby. Chicago and London: University of Chicago Press, pp. 399-424.

Anselm of Canterbury. 2005. Cur Deus Homo? Morrisville: Lulu.com.

Armstrong, Karen. 2000. The Battle for God: Fundamentalism in Judaism, Christianity and Islam. New York: Random House Publishing Group.

Armstrong, Karen. 2004. Fundamentalism and the Secular Society. International Journal: Canada's Journal of Global Policy Analysis 59: 875-77. [CrossRef]

Aron, Raymond. 1962. The Opium of the Intellectuals. Translated by Terence Kilmartin. New York: W. W. Norton and Company.

Aronson, Elliot, Timothy Wilson, and Robin M. Akert. 1994. Social Psychology: The Heart and the Mind. New York: HarperCollins College Division.

Ayoub, Mahmoud. 2007. A Muslim View of Christianity: Essays on Dialogue. Edited by Irfan A. Omar. New York: Orbis Books.

Benedict XVI. 2006. Faith, Reason and the University-Memories and Reflections. Lecture in Regensburg. Available online: http://w2.vatican.va/content/benedict-xvi/en/speeches/2006/september/documents/hf_benxvi_spe_20060912_university-regensburg.html (accessed on 27 January 2020).

Benedict XVI. 2007. Encyclical Letter Spe salvi to the Bishops, Priests and Deacons, Men and Women Religious, and All the Lay Faithful. Available online: http://w2.vatican.va/content/benedict-xvi/en/encyclicals/documents/ hf_ben-xvi_enc_20071130_spe-salvi.html (accessed on 17 January 2020).

Benedict XVI. 2010. Speech in Westminster Hall. Available online: https://www.bbc.com/news/uk-11352704 (accessed on 20 January 2020).

Benedict XVI. 2011. The Listening Heart. Reflections on the Foundations of Law. Address during a visit to the Bundestag. Available online: http://w2.vatican.va/content/benedict-xvi/en/speeches/2011/september/ documents/hf_ben-xvi_spe_20110922_reichstag-berlin.html (accessed on 17 January 2020).

Berlin, Isaiah. 1950. Political Ideas in the Twentieth Century. Foreign Affairs 28: 351-85. [CrossRef]

Bielefeldt, Heiner, and Wilhelm Heitmeyer. 1998. Politisierte Religion: Ursachen und Erscheinungsformen des modernen Fundamentalismus. Frankfurt am Main: Suhrkamp.

Bock-Cote, Matthieu. 2017. Multikulturalizm jako religia polityczna. Translated by Marek Chojnacki. Warszawa: PAX.

Bruce, Steve. 2000. Fundamentalism. Cambridge: Polity Press.

Carr, Edward Hallet. 1951. Bolshevik Revolution 1917-1923. Baltimore: Penguin Books, vol. 1.

Casanova, Jose. 1994. Public Religions in the Modern World. Chicago: University of Chicago Press.

Chesterton, Gilbert Keith. 2017. Biographies. Scotts Valley: CreateSpace.

Chiriyankadath, James. 2010. Hinduism. In Routledge Handbook on Religion and Politics. Edited by Jeffrey Haynes. New York: Routledge, pp. 79-91.

Cowden, Stephen, and Gita Sahdal. 2017. Why fundamentalism? Feminist Dissent 2: 7-38. [CrossRef]

Dorosz, Krzysztof. 2010. Bóg i terror historii. Warszawa: Semper.

Gellner, Ernst. 1992. Postmodernism, Reason and Religion. London and New York: Routledge.

Gierycz, Michał. 2012. Chrześcijaństwo i podstawy polityki. Chrześcijaństwo-Świat-Polityka 13: 26-32. Available online: http://www.chsp.waw.pl/images/wydania/2012/13_MG.pdf (accessed on 20 January 2020). [CrossRef]

Gierycz, Michał. 2017. Europejski spór o człowieka. Studium z antropologii politycznej. Warszawa: Wydawnictwo Naukowe UKSW.

Gierycz, Michal. 2019. Overcoming Reductionism. On "In-depth" Systems Analysis in the Political Science of Religion. Christianity-Word-Politics 23: 41-65. Available online: https://czasopisma.uksw.edu.pl/index.php/ csp/article/view/3641 (accessed on 20 January 2020). [CrossRef] 
Gray, John. 2007. Al Qaeda and What It Means to be Modern. London: Faber and Faber.

Habermas, Jurgen. ; Translated by Kaniowski Andrzej. 2005. Religia w sferze publicznej. Krytyka Polityczna 9/10: 240-51.

Hallermann, Herbert, Thomas Meckel, Michael Droege, and Heinrich de Vaal. 2019. Lexikon für Kirchen-und Religionsrecht. Band 2. Padeborn: Ferdinand Schöningh, p. 105f.

Harrison, Victoria. 2008. Modernity, religious fundamentalism and the secularization thesis. The Icefai University Journal of History and Culture 2: 7-21.

Haynes, Jeffrey. 2010. Religious Fundamentalisms. In Routledge Handbook of Religion and Politics. Edited by Jeffrey Haynes. New York: Routledge, pp. 159-173.

Iwaszkiewicz, Jarosław. 1972. Od tłumacza. In Bojaźn i drżenie. Choroba na śmierć. Edited by Soren Kirkegaard. Warszawa: PWN, pp. IX-XXXIX.

Janicki, Mariusz, and Wiesław Władyka. 2015. Katolicyzm polityczny. Polityka 2968: 15. Available online: http://www.polityka.pl/tygodnikpolityka/kraj/1586895,1,fundamentalisci-z-pis-szykuja-sie-dowladzy.read (accessed on 17 January 2020)

Jansen, Jonatan. 1997. The Dual Nature of Islamic Fundamentalism. New York City: Cornell University Press.

John Paul II. 1991. Encyclical Letter Centesimus Annus to His Venerable Brother Bishops in the Episcopate, the Priests and Deacons, Families of Men and Women Religious, all the Christian Faithful, and to All Men and Women of Good Will on the Hundredth Anniversary of Rerum Novarum. Available online: https://w2.vatican. va/content/john-paul-ii/en/encyclicals/documents/hf_jp-ii_enc_01051991_centesimus-annus.html (accessed on 17 January 2020).

John Paul II. 1993. Encyclical Letter Veritatis Splendor Addressed by the Supreme Pontiff Pope John Paul II to all the bishops o the Catholic Church regarding certain fundamental questions of the Church's moral teaching. Available online: http://www.vatican.va/content/john-paul-ii/en/encyclicals/documents/hf_jp-ii_ enc_06081993_veritatis-splendor.html (accessed on 17 January 2020).

John Paul II. 1997. Encyclical Letter Fides et ratio of the Supreme Pontiff John Paul II to the Bishops of the Catholic Church on the Relationship Between Faith and Reason. Available online: http://w2.vatican.va/content/johnpaul-ii/en/encyclicals/documents/hf_jp-ii_enc_14091998_fides-et-ratio.html (accessed on 17 January 2020).

Kant, Immanuel. ; Translated by Mary C. Smith. 1784. What is Enlightenment. Available online: http: //www.columbia.edu/acis/ets/CCREAD/etscc/kant.html (accessed on 20 January 2020).

Keddie, Nikki R. 2003. Modern Iran: Roots and Results of Revolution. New Haven: Yale University Press.

Kepel, Gilles. 1994. The Revenge of God: The Resurgence of Islam, Christianity and Judaism in the Modern World. Pennsylvania: Pennsylvania State University Press.

Kijas, Zdzisław. 2010. Fundamentalizm i ponowoczesność wobec prawdy. In Postmodernizm i fundamentalizm a prawda. Od idei do praxis. Edited by Halina Grzmil-Tylutki and Agnieszka Hennel-Brzozowska. Kraków: Jagiellonan Univeristy, pp. 15-24.

Kłoczowski, Jan A OP. 2004. Religia. In Słownik społeczny. Edited by Bogdan Szlachta. Kraków: WAM, pp. 1063-80.

Kłodkowski, Piotr. 2006. O pęknięciu wewnątrz cywilizacji. Warszawa: Dialog.

Kołakowska, Agnieszka. 2010. Wojny Kultur i inne Wojny. Warszawa: Teologia polityczna.

Lenin. 1918. The State and Revolution. Available online: https://www.marxists.org/ebooks/lenin/state-andrevolution.pdf (accessed on 17 January 2020).

Marczewska-Rytko, Maria. 2007. Religious Fundamentalism: Theoretical Problems. Polish Political Science XXXVI: 215-23.

Maritain, Jacques. 1928. Three Reformers: Luther, Descartes, Rousseau. London: Sheed \& Ward.

Mazurkiewicz, Piotr. 2007. Eschatologia-etyka-polityka. Chrześcijaństwo -Świat-Polityka 2: 29-32. Available online: http://www.chsp.waw.pl/images/wydania/2007/3_PM.pdf (accessed on 20 January 2020).

Mazurkiewicz, Piotr. 2012. Polityczna niepolityczność Kościoła. Chrześcijaństwo-Świat-Polityka 13: 5-20. Available online: http://www.chsp.waw.pl/images/wydania/2012/13_PM.pdf (accessed on 20 January 2020). [CrossRef]

Mazurkiewicz, Piotr, and Michał Gierycz. 2016. Europäische Anthropologie und europäische Politik. Beobachtungen in der Gegenwart. In Europa und die Anthropologie seiner Politik. Der Mensch als Weg der Geschichte-Zur Philosophie Karol Wojtylas. Edited by Christoph Bohr and Christian Schmitz. Berlin: Berliner Wissenschafts-Verlag, pp. 133-76. 
Ozzano, Luca. 2009. Religious Fundamentalism and Democracy. Politics And Religion 1 III: 127-53.

Perra, Marcello. 2005. Wprowadzenie. In Europa Benedykta w kryzysie kultur. Edited by Joseph Ratzinger. Translated by Wiesława Dzieża. Częstochowa: Święty Paweł, pp. 21-37.

Pratt, Douglas. 2020. Religious Fundamentalism: A Paradigm for Terrorism? Australian Religion Studies Review (pre-published). Available online: https://www.researchgate.net/publication/250014440_Religious_ Fundamentalism_A_Paradigm_for_Terrorism (accessed on 17 January 2020).

Ratzinger, Joseph. 2005. Europe in the Crisis of Cultures. Communio 32: 345-46. Available online: https: //www.theway.org.uk/endeanweb/ratzinger32-2.pdf (accessed on 20 January 2020).

Rausch, Cassandra. 2015. Fundamentalism and Terrorism. Journal of Terrorism Research 6: 2. [CrossRef]

Riesebrodt, Martin. 2004. Was ist "religioeser Fundamentalismus"? In Religioeser Fundamentalismus. Vom Kolonialismus zur Globalisierung. Edited by Clemens Six, Martin Riesebrodt, Siegfried Hans and Wien Innsbrueck. München and Bozen: Studien Verlag, pp. 13-32.

Sacks, Jonathan. 1991. The Persistence of Faith: Religion, Morality and Society in Secular Age. London: Weidenfeld \& Nicolson.

Scheler, Max. 1921. Vom Ewigen in Menchen. Ersten Band Religiose Erneuerung. Leipzig: Der Neue Geist.

Schlegel, Jean-Louis. 2003. La loi de Dieu contre la liberté des hommes: Intégrismes et fondamentalismes. Paris: Le Seuil. Solovyov, Vladimir. 1988. Wybór pism. Poznań: PIW, Volume 1.

Sowell, Thomas. 2007. A Conflict of Visions. Ideological Origins of Political Struggles. New York: Basic Books.

Spaemann, Robert. 2012. Kroki poza siebie. Translated by Jarosław Merecki. Warszawa: Oficyna Naukowa.

Springer, Sławomir. 2010. Protestancka myśl teologiczna w obliczu krytyki filozoficznej. Przegląd Religioznawczy 2: 41-50.

Sulkowski, Mariusz. 2018. Ideologia Państwa Islamskiego. Chrześcijaństwo - Świat - Polityka 22: 211-30. Available online: https://czasopisma.uksw.edu.pl/index.php/csp/article/view/3230 (accessed on 20 January 2020). [CrossRef]

Szulakiewicz, Marek. 2005. Osoba i chrześcijaństwo w okresie dehellenizacji współczesnej kultury. Filozofia chrześcijańska 2: 177-92.

Thomas, Aquinas. ; Translated by Fathers of the English Dominican Province, and Benziger Bros. 1947. Summa Theologica. Available online: https://www.ccel.org/a/aquinas/summa/cache/summa.pdf (accessed on 20 January 2020).

Tibi, Bassam. 1997. Fundamentalizm Religijny. Translated by Janusz Danecki. Warszawa: PIW.

Vanberg, Victor. 1987. Conflict of Visions. Thomas Sowell. Cato Journal 7: 547-50.

Vincent of Lerins. ; Translated by C.A. Heurtley. 1894. Commonitorium. Available online: http://www.newadvent. org/fathers/3506.htm (accessed on 20 January 2020).

Voegelin, Eric. 1975. From Enlightenment to Revolution. Durnham: Duke University Press.

Voegelin, Eric. 2000. Political Religions. In The Collected Work of Eric Voegelin. Volume 5: Modernity without Restraint. Translated by Virginia Ann Schildhauer. Columbia: University of Missouri Press, pp. 19-73.

Waqas, Syed M. 2015. Jewish and Hindu Beliefs and Thought Patterns. Comparing and Contrasting Various Aspects of the Two Most Ancient Religions of the World. Cincinnati: Department of Biblical Studies, Cincinnati Christian University, Available online: https://www.researchgate.net/publication/328943327_JEWISH_AND_HINDU_ BELIEFS_AND_THOUGHT_PATTERNS_Comparing_and_Contrasting_Various_Aspects_of_the_Two_ Most_Ancient_Religions_of_the_World (accessed on 20 January 2020).

Wąs, Adam S. V. D. 2006. Bracia Muzułmanie w Jordanii. Doktryna i organizacja Bractwa na przełomie XX $i$ XXI wieku. Lublin: Towarzystwo Naukowe KUL.

Weigel, George. 2009. Faith, Reason and the War against Jihadism. New York City: Random House.

Wnuk-Lipiński, Edmund. 2004. Świat międzyepoki. Globalizacja. Demokracja. Państwo narodowe. Kraków: Znak.

Zdybicka, Zofia. 2006. Człowiek i religia. Lublin: Towarzystwo Naukowe KUL.

Zenderowski, Radosław. 2014. Islam. In Religia i polityka. Zarys problematyki. Edited by Piotr Burgoński and Michał Gierycz. Warszawa: Elipsa, pp. 67-99.

Zenderowski, Radosław, and Artur Wysocki. 2014. Hinduizm. In Polityka i religia. Zarys problematyki. Edited by Piotr Burgoński and Michał Gierycz. Warszawa: Elipsa, pp. 128-52. 
Życiński, Józef. 1998. O nauce i wierze. In Rozmowy na koniec wieku 2. Edited by Katarzyna Janowska and Roman Mucharski. Kraków: Znak, pp. 21-34.

(ㄷ) (1) (C) 2020 by the author. Licensee MDPI, Basel, Switzerland. This article is an open access article distributed under the terms and conditions of the Creative Commons Attribution (CC BY) license (http://creativecommons.org/licenses/by/4.0/). 

Article

\title{
What Can Faith-Based Forms of Violent Conflict Prevention Teach Us About Liberal Peace?
}

\author{
Laura Payne \\ Centre for Trust, Peace and Social Relations, Coventry University, Coventry CV1 5FB, West Midlands, UK; \\ laura.payne@coventry.ac.uk
}

Received: 7 January 2020; Accepted: 25 March 2020; Published: 3 April 2020

\begin{abstract}
Faith-based actors are often recognised as contributors to both conflict and peace. However, their work to prevent violent conflict, rather than bring an end to or recover from it, is largely unexplored. This is despite the growth of conflict prevention as a global social norm and field of practice. Based on collaborative research with faith groups and organisations in Nigeria, the Solomon Islands and Zanzibar (Tanzania), this paper examines faith-based forms of violent conflict prevention. It argues that faith-based approaches exist on a spectrum, from instinctive and ad hoc initiatives run by individuals and local places of worship to large-scale, systematised interventions led by global faith-based development organisations. Yet, while faith-based approaches to violent conflict prevention vary in form and function, they are consistent and distinctive in their emphasis on building resilient relationships at the local level, modelling forms of prevention embedded within local culture and that recognise the emotional and spiritual dimensions of transformative change. Faith-based approaches offer insights valuable to the wider conflict prevention field, which is increasingly critiqued for its liberal underpinnings and emphasis on technical and technological solutionism. Lessons emerge for others implementing prevention programmes, who could adapt elements of the unhurried, values-led, relationally sensitive approach demonstrated by some faith-based actors, albeit within their own structural limitations. Policymakers should support such adaptations and expand their view of prevention to explicitly include faith-based forms of activity, as to do otherwise risks missing opportunities and reproducing existing failures.
\end{abstract}

Keywords: conflict prevention; faith; religion; liberal peace; peacebuilding; religious violence; technocracy; technology

\section{Introduction}

From the atrocities of Boko Haram and Daesh to the state-sponsored persecution of Myanmar's Rohingya, religiously framed violence dominates headlines and plagues lives. On the flip side, religious actors are also recognised for their efforts to disavow violence and support peace. Whilst both of these constructs are familiar, the roles that religious actors play in preventing outbreaks of political violence are largely unknown (Haider 2016). Based on case studies from Nigeria, the Solomon Islands and Zanzibar, this article introduces examples of faith-based conflict prevention at local and national levels. It considers the contexts in which faith-based conflict prevention occurs and the forms it takes, from reflexive offers of sanctuary and safe passage to early warning and response to long-term efforts to address structural conflict drivers and challenge cultures of violence. It investigates how faith-based approaches conform with, contradict and extend conventional "liberal peace" wisdom and what the implications of this are for conflict prevention as a field of practice.

Faith-based actors range in form, from local faith groups and places of worship, some informally constituted, to international development agencies and global religious movements. All derive inspiration and guidance from the teachings and principles of their faith or a particular interpretation or 
school of thought within that faith (Clarke et al. 2008). In times of violent conflict and in the aftermath, some seek to build peace and lay foundations for recovery, shaping their existing activities to support peacebuilding or taking on new roles. Some faith-based actors function very similarly to non-faith-based peacebuilding actors-in larger faith-based international development agencies, in particular, day-to-day working practices may be largely indistinguishable from others in the sector.

Recent years have seen major faith-based humanitarian organisations enter peacebuilding programming in a more sustained way. Organisations such as Islamic Relief, Christian Aid and Tearfund have recalibrated their activities in conflict-affected areas, supplementing conflict-sensitive development work with activities more explicitly framed as peacebuilding. This responds to growing donor interest, both in partnering with faith-based organisations (Duff et al. 2016) and in peacebuilding. As engagement has increased, debates around working with faith-based actors have matured. Questions of appropriate forms of partnership have come to the fore, along with concerns over instrumentalisation of faith partners and low levels of faith literacy within the development sector. New platforms for partnership have been created, along with "principles" (DfID 2012) and "partnership notes" (UNHCR 2014) to guide interactions.

The growth in faith-based peacebuilding has coincided with the development of conflict prevention as a distinct global norm and field of practice. The latter provides a framework to consider the preventative contributions of faith-based actors, but so far, the literature on the two subjects remains largely separate. This contrasts with the wealth of literature on religion and countering violent extremism or religion and atrocity prevention, which both have a similarly proactive approach to addressing violence. Recognising this knowledge gap, the article integrates the literature on conflict prevention, liberal peace and faith-based peacebuilding and analyses the implications of faith-based initiatives for the prevention agenda and liberal peace more generally. It is significant in a number of ways. Firstly, it contributes to the knowledge base on conflict prevention by expanding the view to include faith-based initiatives, which opens up space for critical reflection of current prevention practice and reveals new pathways for reform. Secondly, it contributes to debates within the faith-based peacebuilding literature, as it sets out the parameters of faith-based conflict prevention, as yet unestablished, and identifies avenues for further research in this underexplored area. Finally, this article recommends ways to adapt programming to enable deeper engagement as calls for prevention grow stronger.

The paper continues with a brief methodological overview. It then provides a brief overview of approaches to religion within peace studies, recognising the ambivalent heritage that religious actors have as instigators and inhibitors of violence. Section 4 examines conflict prevention, charting its evolution from generic aspiration to global social norm and field of practice, and Section 5 considers conflict prevention as an extension of the liberal peace agenda. Section 6 documents case studies of faith-based forms of conflict prevention, identifying common themes linked to the faith-based organisations' dual identities as local and spiritual actors. Three persistent weaknesses of conflict prevention are then unpacked in order to examine the extent to which faith-based initiatives conform with, contradict and extend conventional "liberal peace" wisdom. The final section concludes, reflecting on the extent to which faith-based initiatives can add value and identifying pathways for future research.

\section{Methodology}

The data that inform this research were collected through two projects. The first was The Faith-Based Conflict Prevention and Early Warning Scoping Project, a collaboration between academics and the Anglican network of churches, the world's third largest church grouping. The project analysed the experiences of faith groups working to prevent conflict in Nigeria and the Solomon Islands through interviews, focus groups and participant observation at meetings and workshops, exploring what is distinctive about faith-based approaches. In the Nigerian cities of Jos and Kaduna, researchers engaged with 249 respondents across 30 organisations in 32 sessions, observing interfaith organisations as well as Christian-led initiatives. In Honiara, Solomon Islands, researchers interviewed 23 leaders from faith 
organisations and other entities, interacting with 98 additional respondents through workshops and faith group activities. Respondents included members of the Melanesian Brotherhood, an Anglican religious order of lay brothers unique for its large size and relative youthfulness, as the option to renew vows intermittently makes it a popular choice for young men to live in a spiritual community for a fixed time. In both contexts, respondents included a mix of ordained faith leaders and lay people, peacebuilding practitioners and development workers, community members involved in peacebuilding activities, and donors and policymakers.

Data also come from a second project, From Early Warning to Response in Preventing Violence: Transforming Conflict Through Citizen Engagement, in collaboration with the Action Support Centre (South Africa). Through participatory action research, the project investigated the effectiveness of information, communication and technology (ICTs) in conflict early warning and early response initiatives. This paper includes insights from Zanzibar, a semi-autonomous region of Tanzania, where the local partner was the Zanzibar Interfaith Centre.

A full analysis of the conflict dynamics in each area is beyond the scope of this paper, but extensive conflict analyses were conducted with partners in each country to situate the research, mapping conflict issues, key stakeholders and peacebuilding assets. In all cases, respondents identified multiple competing forms of conflict. In Nigeria and Zanzibar, respondents identified religious dimensions to conflicts, though this was not necessarily the central issue. Often, religion was the fault line upon which opinion was divided or a surface narrative framing other concerns. In Zanzibar, for instance, a prescient issue for respondents was unease with rapid modernisation and Westernisation, epitomised through mass tourism. Zanzibaris receive minimal financial benefit from this, whilst struggling to cope with the associated uncontrolled migration and perceived moral decay (Keshodkar 2013). According to local partners, religion intersects by providing an Islamic moral traditionalism as an alternative to "Western" immodesty and decadence. In all areas, religion was identified as one of many identity markers influencing peace and conflict dynamics, alongside others such as ethnicity, indigeneity and class.

For both projects, the interviews, focus groups and workshops were designed by a mixed team of academic researchers and faith-based research partners. For each session, responses were transcribed by two researchers who later validated their findings with each other. Data were grouped into themes by the team, and synthesised findings were later presented to a wider group of external stakeholders, both faith-based and secular, who have experience and expertise in the sector.

As the literature review will show, the academic exploration of faith-based forms of conflict prevention is in its infancy. An empirical approach, based on case studies, was chosen to gain an overview of the substance, extent and impact of faith-based conflict prevention initiatives. The format of knowledge exchange with faith-based partners was also important, as it provided ways to bridge contextual and thematic expertise, mitigate asymmetric power relationships, avoid extractive research, recognise colonial legacies and ultimately "do no harm". The methodology reflects a move towards participatory approaches and knowledge networking with religion and development (Bompani 2019) and peace studies (Verkoren 2006) more generally. These forms of research come with challenges, notably the possible influence of partners' biases on the research process and findings. Researchers were mindful of this and introduced checks and balances, including systematic research design and external feedback, but ultimately found that working within mixed academic/practitioner and secular/faith-based teams supported a research culture that was conscious of positionality, reflective and frank in assessing successes and failures.

In analysing faith-based forms of conflict prevention, both projects avoided seeking grand theories and narratives to "explain" the phenomenon. Scholars have often highlighted the pitfalls of making sweeping statements regarding the roles of religious actors in peace and conflict, instead recognising the overall "ambivalence of the sacred" (Appleby 2000; Philpott 2007). Ultimately, this article seeks to identify what faith-based forms of conflict prevention can be, rather than what they definitively are. 


\section{Religion, Conflict and Peacebuilding}

Links between religion, conflict and violence are complex and much interrogated, but those between religion and peacebuilding receive less attention. This reflects a tendency of scholars to study peace through its absence rather than its presence and the biases of a largely secular academy (Shannahan and Payne 2016). Within the social sciences, religion is often side-lined, including in disciplines such as international relations (Johnston and Sampson 1994) and development studies (Bompani 2019). Within peace studies, however, a strong and coherent body of scholarship around religious engagement in peacebuilding has emerged. Many analyses of this coalesce around Appleby (2000) work on the "ambivalence of the sacred", which acknowledges that religious actors are important "purveyors of ideas" (Haynes 2011) capable of driving both conflict and peace. Scholars have examined a spectrum of different forms of faith-based action, including in mediation, dialogue and track-II diplomacy (Bercovitch and Kadayifci-Orellana 2009; Toft et al. 2011; Johnstone and Svensson 2013), humanitarianism, development and displacement (Ager et al. 2015), and post-conflict reconstruction, reconciliation and trauma resolution (Putman et al. 2011). Case studies document initiatives within Christianity (Sampson and Lederach 2000; Appleby 2000; Johnston and Sampson 1994), Islam (Abu-Nimer 2003) and non-Western religions (Galtung and MacQueen 2008; Neumaier 2004). A growing body of work also highlights the role of religious women in peacebuilding (Hayward 2015; Hayward and Marshall 2015).

\section{The Evolution of Conflict Prevention as a Global Norm and Field of Practice}

In essence, conflict prevention is the effort to prevent tomorrow's violence today. As such, it is relevant at any stage of conflict where violence is anticipated. It requires the proactive identification of conflict triggers and a subsequent response to prevent violence from breaking out or escalating and thus entails both foresight and action. Operational prevention responds to the imminent onset of violence through early warning and response, often using monitoring data provided by field monitors, volunteers or the public. Flagship initiatives have emerged, including CEWARN, an East African model to prevent cross-border pastoralist conflicts through stakeholder collaboration, information sharing and formulating response options. Structural prevention addresses the underlying causes of conflict, aiming to transform these for the long term. The drive for prevention stems from the recognition that prevention is cheaper than cure (Chalmers 2006) and awareness that conflict is a barrier to progress, exacting a heavy toll on human life and on economic, social and political systems. It also reflects a turn to discourses of prevention and precautionary policymaking more generally, in areas as varied as health, early years interventions, poverty, criminality and climate change (Coote 2012; Gough 2013).

Conflict prevention is at the United Nations' (UN) core, with its renowned preamble beginning, "We the peoples of the United Nations determined to save succeeding generations from the scourge of war, which twice in our lifetime has brought untold sorrow to mankind ...". Its development as a global norm and field of practice came in the Boutros-Ghali era, with the development of "preventative diplomacy" in the 1992 Agenda for Peace. Successive Secretary Generals maintained focus, with Annan shifting to a "culture of prevention", Ban Ki-Moon declaring 2012 the "year of prevention" and current Secretary General Guterres declaring prevention the number one priority. The Responsibility to Protect (R2P) was adopted by all UN member states in 2005, with the UN developing early warning capacity to prevent genocide, ethnic cleansing and crimes against humanity.

At the regional level, the European Union (EU) adopted conflict prevention as an explicit objective through the Lisbon Treaty (Vanheusden 2010). The African Union (AU) developed preventative tools within the Africa Peace and Security Architecture. In 2017, it adopted the AU Master Roadmap on Practical Steps for Silencing the Guns by 2020. The Association of Southeast Asian Nations (ASEAN) has focused on "preventative diplomacy", a state-centric approach to prevent conflict between member states while respecting strong norms of sovereignty that exist within the region (Della-Giacoma 2011). Other regional and sub-regional organisations have their own frameworks. Whilst the development of prevention architectures at regional level is undoubtedly positive, they do not always live up to 
expectations. Wulf and Debiel (2009) cite the difficulty of navigating different values and conceptions of sovereignty, lack of coordination and capacity and dominant regional powers as stumbling blocks.

The practice of conflict prevention originally lagged behind its development as a global norm (Aggestam 2003) but has grown significantly. Whilst early generations of operational prevention tended to be internationally driven, recent initiatives are likely to be community focused and technology enabled. Local actors are now perceived to have several advantages over international organisations, including flexibility, efficiency, approachability and familiarity with culture and context. Forms of programming have become more imaginative, with interventions based on crowdsourcing, GPS mapping and big data being piloted and mainstreamed. Alongside civil society programmes, there has also been a "privatisation" of prevention, with the business sector developing its own initiatives in response to public pressure (Haufler 2004). These tend to focus on the extractive industries, with a prominent example being the Kimberley Process Certification Scheme for diamond mining (Haufler 2010).

As conflict prevention has developed, criticisms have emerged that its practice appears weak compared to its promise (Aggestam 2003; Matveeva 2006; Wulf and Debiel 2009). Operational and structural approaches are not always well aligned, reflecting their divergent understandings of conflict and prevention (Aggestam 2003). Indicators that facilitate operational prevention can have a "straight-jacketing" effect and provide a negative basis for analysis, measuring communities' risks and exposure to violence but not their resilience and capacities (Anderson and Wallace 2012). Challenges exist in relation to the credibility and reliability of evidence and a persistent gap often remains between warning and response. Community-based organisations may have been brought into the fold, but international actors often engage in ways that are extractive (Saferworld and Conciliation Resources 2016), for instance by harvesting early warning data from local partners upon which they are unable to act. Such engagement lacks effectiveness and is ethically questionable, as it depletes local partners of time and energy without the prospect of results.

Finally, the analysis and critique of conflict prevention has been hindered by a lack of conceptual clarity. Firstly, the term is overused within the peace studies literature and peacebuilding sector, where "prevention" is often used interchangeably with "peacebuilding" and "conflict resolution". This imprecision risks embracing initiatives where the term prevention has been adopted but the preventative element is not well developed. Secondly, the term conflict prevention is underused by local actors, including faith-based actors, who may have their own vernaculars or reject the labelling of their work this way. So, the challenge is two-fold: adopt a wide definition and the distinction with other forms of peacebuilding is unclear; adopt a narrow definition and local and faith-based initiatives may be excluded. This article strikes a balance by including all activities that are discernibly preventative, irrespective of whether the terminology of prevention is applied and by excluding activities that are claimed to be preventative but not demonstrated to be so. To assess preventative effect, the article utilises Coote (2012) distinction between upstream, midstream and downstream interventions. Upstream interventions seek to prevent harm before it occurs, targeting structural causes, midstream interventions mitigate the effects of harm and are usually targeted at "at risk" groups and individuals, and downstream interventions cope with the consequences of harm. Upstream and midstream interventions are included within the analysis, whereas downstream interventions are excluded. This allows the study to exclude forms of action that are based on what one respondent referred to as "the fire brigade approach", where action is only taken reactively.

\section{Conflict Prevention as an Extension of Liberal Peace}

Liberal peace claims to provide a universal ideology for peace, based on an international order of rational, democratic, secular, free-market and human rights-abiding states, together with technical processes and technologies to achieve it. For critics and proponents alike, it represents the internationalisation of a particular form of government-free market liberal democracy (Sabaratnam 2011). In conflict and post-conflict countries, liberal peace generally focuses on the structural reform 
of domestic institutions, the failures of which have arguably created the conditions for conflict to emerge. These reforms may seek to establish or alter the country's constitution, institutionalise democracy or raise capacity within key state functions such as the legislature, judiciary and security services. Such processes are political and very technical and so engender forms of peacebuilding that are top-down and highly professionalised. They are often promoted by the international community, which provides substantial engagement and sometimes muscular intervention in the way of humanitarian and development aid, peacekeepers and even occasionally full-scale military occupation. Whilst such substantial reforms may be contentious and destablising for any country, they are frequently enacted within "fragile states where customary law, traditional authorities and informal "indigenous" institutions often hold greater sway than the state (Boege et al. 2009).

Liberal peace has its strengths, particularly for those whose rights are insecure. Yet, it also has significant ideological baggage, including Eurocentrism, technocentrism and historic connections with empire (Richmond and Ginty 2015). Richmond (2009) argues that in many post-conflict environments, local opinion perceives liberal peace to be "ethically bankrupt, subject to double standards, coercive and conditional, acultural, unconcerned with social welfare, and unfeeling and insensitive towards its subjects". Imposed from above, it risks degrading into violence if its universal aspirations are not reflected on the ground (Richmond 2009). Critiques of liberal peace have come from those who seek improvements in theory and practice but fundamentally accept the paradigm and those radically opposed (Chandler 2010). Many critiques revolve around notions of the "everyday" and the "local turn", which recognise increased assertiveness by local actors and a loss of confidence by some international actors (Mac Ginty and Richmond 2013). The concepts of "hybridity" and "post-liberal peace" have also emerged, attempting to draw out more complex understandings of relationships between the local and the international in peacebuilding. However, these have also been critiqued by pro-liberal scholars, who argue that these concepts have not pointed to a clear alternative path for peacebuilding and that liberal peace has still done more good than harm (Paris 2010).

Historically, religion and liberalism have been uneasy bedfellows. Cavanaugh $(1995,2009)$ charts how early proponents of the modern state system perpetuated a "myth" of religious violence to legitimise its liberal and secular foundations. He argues that much of this so-called religious violence was actually "resistance of local elites to the state building efforts of monarchs and emperors" (Cavanaugh 2009, p. 177). Today, the liberal peace paradigm still struggles to contend with religion, particularly where it challenges secular sovereignty (Mullin 2010). Religious traditions are also forced to reckon with liberalism, generally operating within the paradigm with varying enthusiasm. Religious actors must also consider their own culpability for atrocities perpetrated under ostensibly liberal state-building, such as colonialism (Lynch 2015). Yet, as Gopin (2015) reminds us, it is easy to overstate the differences between liberal peace and religious models, as enlightenment principles such as peace, human rights and democracy are also rooted in religious texts and practices.

Over the past several years, religious peacebuilding scholars have begun to deconstruct liberal peace and its implications for faith-based peacebuilding. Appleby and Lederach offer a corrective in their concept of strategic peacebuilding (Lederach and Appleby 2010), which pursues peace with justice ("justpeace") and embraces elicitive methods that foreground indigenous knowledge and culture over expert input, shifting agency further towards the local (Appleby 2015). In substance and approach, strategic peacebuilding articulates at least a partial rejection of liberal peacebuilding, which Appleby characterises as "Western, bureaucratic, ends-driven, materialist and top-down" (Appleby 2015, p. 190).

Given the overwhelming pervasiveness of the liberal peace paradigm, the development of conflict prevention as norm and practice has necessarily taken place within it (Hauge et al. 2015). Most forms of conflict prevention have shorter term goals than peacebuilding, geared more towards the aversion of violence and the maintenance of stability, but its function is ultimately to provide an enabling environment for liberal peacebuilding. The practice of prevention also shares key characteristics with liberal peace, with its privileging of external knowledge and models and its technocratic approach. The literature examining conflict prevention as a liberal peace project is small but critical. Jacobsen 
and Jacobsen and Engell (2018) argue that prevention is an extension of liberal interventionism. Their view is that interventionism has retreated but has been replaced by new forms of technology-enabled intervention under the rubric of prevention. Others argue that liberal peace approaches to prevention can undermine communities' capacity to prevent conflict, for instance by omitting to identify what is already working locally (Anderson and Wallace 2012) or by emphasising security and political reform at the expense of socio-economic changes (Hauge et al. 2015).

Many of the key criticisms of conflict prevention emerge from its ideological underpinnings in the liberal peace. Here, this paper briefly analyses three-its technocratic disposition, overreliance on information and communication technologies (ICTs) and short-termism. These are not the only criticisms of liberal peace, and they are not all to which liberal peace should be reduced. However, they are prominent and observable hallmarks of the concept that can be readily operationalised and thus provide a framework for comparing classical liberal peace interventions with those implemented by religious actors. The paper revisits these three areas again later to consider the potential value added by faith-based approaches.

\subsection{Technocratic Disposition}

Technocracy has its advantages, especially in conflict-affected environments (Mac Ginty 2018). However, liberal peacebuilding has been criticised for being increasingly technocratic and professionalised, which poses barriers to local ownership and participation. Kurtz and Meyer (2018) argue that technocratic understandings of conflict prevention are now widespread, based on positivist conflict forecasting and toolbox approaches to "what works", delivered with a heavy dose of "wishful thinking" about warning-response dynamics. They call for greater focus on the "art" of conflict prevention, paying closer attention to the informal, individual and political dimensions of the endeavour. Religious peacebuilding scholars have also underlined the creativity and discernment needed for sustainable peacebuilding, which technocracy and formulaic approaches can stifle. As Lederach (2001, p. 203) notes, "Authentic reconciliation will never be packaged and delivered at drive-through windows".

\subsection{Over-Reliance on Information and Communication Technologies}

ICT for conflict prevention has had some high-profile successes, such as the Ushahidi project's mapping of election violence ${ }^{1}$ and Una Hakika's countering of misinformation through its "WikiRumours" software. ${ }^{2}$ At their best, ICTs facilitate information sharing, communication and coordination, all of which are essential for collective action. Yet, they are not neutral tools, and their deployment is both shaped by and shapes political economy. Where violence arises from a breakdown in communication or a lack of accurate information, tools that improve these can theoretically help to prevent violence (Martin-Shields 2013). However, of course, ICTs are not a panacea. Trust is a crucial element in peacebuilding (De Juan and Pierskalla 2014), and where this is low, ICTs may not be effective (Leach 2016). So far, evidence on the impact of technology-enhanced conflict prevention initiatives is mixed. Projects have often misfired, promoting supply-driven technical fixes, introducing unfamiliar and unsustainable technology and pushing technological solutions onto political problems (Leach et al. 2015).

\subsection{Short-Termism}

Sustainable conflict prevention involves substantive institutional reform to address structural drivers of conflict, requiring long-term engagement. Yet, the temporal aspect of prevention is often

1 Ushahidi means "witness" in Swahili. The Kenyan platform originally emerged to track post-election violence in the country in 2007-2008 but has now been used for many purposes across Africa.

2 Una Hakika means "You are Certain" in Swahili. The initiative seeks to verify information and counter rumours. 
overlooked by donors and policymakers. In fact, the liberal peace toolbox seems a hindrance to appropriate timing, given that donors tend to withdraw their engagement when risks escalate and political actors only engage when the risk of violence is high or violence is already present (United Nations and World Bank 2018).

\section{Faith-Based Conflict Prevention}

There have been very few substantive analyses of faith-based violent conflict prevention in the academic literature. Notable exceptions include Hertog (2010), who explores the peace-inculcating values and ethics of religion and the potential of these for violence prevention, and Palihapitiya (2018), who considers faith-based early warning systems. A small number of policy-focused reflections exist (Haider 2016; Perchoc 2016). This is despite the fact that initiatives have long been common at the local level, where religious actors are well placed to respond to early signs of violence and are increasingly being adopted by international faith-based NGOs. National-level religious leaders often have public platforms to raise the alarm as peace deteriorates. Internationally, many larger faith traditions have secretariats and representatives at global institutions, through which they can raise issues on the global stage. As examples, the Holy See is a permanent observer state at the United Nations, and the Anglican Communion also retains a representative to the United Nations in Geneva and New York.

In all of the case studies, respondents evidenced a range of faith-based conflict prevention initiatives. During the conflict in the Solomon Islands, young monks slept on the battle lines in a "middle camp" between warring militias. They provided security at the airport, allowing planes importing vital goods to land and preventing further deterioration of law and order. Church leaders escorted people in danger, providing safe passage and sanctuary. In the aftermath, monks collected weapons on behalf of the Regional Assistance Mission to the Solomon Islands (RAMSI), preventing retaliatory gun violence. Church leaders mediated local disputes around land to prevent them spiralling. They brokered interpersonal and communal reconciliation and healing and ran training workshops on non-violent conflict resolution. Churches were instrumental in establishing a Truth and Reconciliation Commission, which included a forward-looking set of reforms "designed to prevent a recurrence of violence" (Jeffrey and Mollica 2017). When the government refused to release the Commission's report, one Bishop controversially leaked it to the media.

In Nigeria, religious peacebuilding initiatives were mostly led by local faith-based NGOs with strong ties to religious communities. Conflict prevention activities included the formation of conflict early warning and response teams and GPS mapping of violence. One organisation literally counted the costs of conflict with villages (what is the cost of a dead cow, a burned-out building, the loss of a breadwinner). Thinking long term, another organisation ran interfaith youth livelihood programmes, including a residential farm bringing together Christian and Muslim youth from different ethnic groupings in shared dormitories. Women's faith groups ran religious literacy classes with prisoners, pushing back against attempts to justify violence through religious doctrine. A high point for religious peacemakers was the signing of the Kaduna Peace Declaration of Religious Leaders in 2002. Musa (2016) argues that this had an immediate preventative effect: when Kaduna's Muslim youth rioted against Nigeria hosting the Miss World Beauty pageant, Christian and Muslim leaders were proactive in quelling violence. A total of 250 people were killed in the Miss World riots; two years previously, the shari'a riots claimed over 2500 lives.

Finally, in Zanzibar, a Joint Committee of Religious Leaders regularly sought to deescalate tensions by dispelling rumours and appealing for calm. An interfaith organisation ran activities to promote peace during elections, improve community policing and enable youth to advocate for peace. They have also set up more than 300 local peace committees throughout the island to monitor peace. ${ }^{3}$

3 An in-depth analysis of the Committee's work has been conducted by Langås (2019). 
In all cases, respondents could identify highly localised indicators of potential violence. These included chieftain disputes, lorries on the road at night (signifying illicit activities and the breakdown of law and order), violence in neighbouring areas, the unexpected arrival of strangers, rumours circulating by SMS, a ban or curfew on motorcycle drivers, adversaries relocating cattle, circulation of leaflets in the market and proselytising during other faiths' religious holidays. Longer term indicators included "irregular" migration (with irregular in this instance referring to migration against customary practices), ethnic segregation/ghettoisation of inner-city areas, the sweeping aside of unaddressed grievances and rapid cultural change/Westernisation. Respondents could also connect these to global triggers, including the Danish cartoon controversy of 2002, in which a Danish newspaper published cartoons depicting the Prophet Mohammed as a terrorist, and the fall of Gaddafi in Libya, which increased access to small arms.

In conducting their prevention activities, faith-based actors were found to benefit from three forms of overlapping capital: local capital, on the one hand, and religious and spiritual capital on the other. In this article, local capital refers to the strengths and advantages that local actors may have by virtue of their positioning and proximity to communities. As such, it is an extension of social capital, a term popularised by Putnam (2000) to denote a public good derived from "connections among individuals—social networks and the norms of reciprocity and trustworthiness that arise from them". In the case studies, local faith-based organisations often utilised local capital—they were quick to pick up on and interpret subtle changes in conflict indicators, given their familiarity with local norms, culture, practices and vernacular. They were also known entities with an existing store of goodwill upon which to draw.

Religious capital refers to the practical contributions made by faith groups based on their resources, while spiritual capital refers to the ethical, theological, scriptural and spiritual values that energise this (Baker 2009). Some definitions combine both forms of capital under the same heading of either "religious" or "spiritual", but there is greater conceptual clarity in separating the two. "The spiritual is associated with the personal, the intimate, the interior and the experiential, contrasted with 'religion', which is associated with the official, the external and the institutional, often picking up negative connotations of the hierarchical and patriarchal along the way" (Guest 2007; Heelas 2002). Of course, a long tradition of philosophers, from Marx (1844) to Weber (1964) to Bourdieu (1987), highlight that the use of religious and spiritual capital is not always benign. Few religious peacebuilding scholars would dispute this-indeed, it is further evidence of the ambivalence of the sacred.

In the case studies, faith-based actors strongly utilised their religious capital. Most had access to well-located premises for meetings and activities. Often, religious leaders had access to other local leaders, including those in politics, media and the aid sector. In Nigeria, some faith leaders had their own TV talk shows. Depending on their circumstances and institutional structures, many leaders could escalate matters to national and international leaders through denominational, ecumenical and interfaith networks. Faith groups also had their own financial resources, which, though small, offered a level of stability and continuity.

Critically, faith groups also utilised their spiritual capital. Activities observed by the research team were distinctly value driven, emphasising concepts of justice, compassion and human flourishing and affirming these through prayer and the use of religious doctrine, storytelling and symbolism. This was done as a matter of conviction, rather than utility, but nevertheless had the potential to allow people to move beyond their own interests and look at the common good. The use of religious ritual and symbolism was often important for communities-in the Solomon Islands, the hands of former combatants were symbolically washed when they handed over their weapons, signifying a spiritual cleansing that was meaningful for them. Respondents explained how prevention activities were designed to connect at an individual's innermost levels, going beyond the cognitive to enter what some might see as a spiritual realm or what others might see as an emotional or psychological one. 
Only church vehicles could pass through the [militia] camps, but once our vehicle was stopped. The priest came back and told me, and I said 'go and tell them that vehicle is a church. If they hold it, they are holding a church'. (Christian faith leader, Solomon Islands).

This readiness to engage more deeply is important, as emotions are an essential part of transforming conflict (Bramsen and Poder 2018). It also gives activities credence: "You need some theological basis, or this is just a government agenda" (Christian faith leader, Nigeria).

Of course, faith-based engagement in conflict prevention is far from perfect. Some religious actors are openly hostile to such initiatives and may even be key conflict protagonists. In Nigeria, respondents explained that hate preaching by religious leaders contributes to violence: "Before preaching was very balanced, but today it can be too extreme" (Muslim faith leader, Nigeria). Nor are faith-based actors immune from the creeping elitism that the wider field of conflict prevention has been charged with. "Interfaith work is all up, up, up, they will continue going up until they meet Jesus! But there are people down there. We need to go much more local. Relationships have to be formed at a local level, between youth" (Christian youth leader, Nigeria). Where faith groups have a middle-class bias, they can also struggle to access those most easily mobilised into violence, who are often youth from poor families. In the Solomon Islands, the monks of the Melanesian Brotherhood were roughly the same age as the militias and, in some cases, had been to school with them, enabling them to build rapport. In Nigeria, however, one civil society leader observed that religious leaders were losing influence over youth, with implications for their prevention work: “The religious leaders aren't following youth, they aren't at the football fields, and youth are major actors" (Civil society leader, Nigeria).

\section{Conflict Prevention: Lessons from Faith-Based Initiatives?}

This final section of the paper revisits the three criticisms of conflict prevention set out earlier and identifies the potential added value of faith-based initiatives.

\subsection{Technocratic Disposition}

In the case studies, faith-based organisations tended to prioritise relationship-building and shifts in perspective ahead of tactical attempts to moderate or problem-solve issues. After all, "When you develop infrastructure instead of humanity, they will just come and blow it up" (Muslim faith leader, Nigeria). Whilst some initiatives targeted particular individuals, many others focused on changing relationships and attitudes within the whole community. This echoes the relational consciousness that many religions embrace- and that, incidentally, many liberal thinkers tend to downplay (Hay 2000):

We don't just tackle the youth who go and fight, we consider the women who cook for them and the men who buy them pure water, the politicians and the prominent men and women, and the market traders who sell guns.

(Faith-based development worker, Nigeria)

Relationships between religious leaders of different faiths were recognised as particularly important, as they have significant influence over their followers: "For us preventing violence means continuous dialogue. $99 \%$ of our work is conflict prevention. If leaders are talking, everyone will be calm" (Inter-faith worker, Zanzibar). The authenticity of relationship was also important, as, otherwise, initiatives lose legitimacy: "There are people in [the Muslim faith] I can trust. One imam is bent on telling the truth, he is educated in the Bible and the Quran. We call each other when things are bad" (Christian faith leader, Nigeria).

\subsection{The Reliance on ICTs in Conflict Prevention}

In the case studies, faith-based actors displayed varying levels of engagement with ICTs for conflict prevention. In some countries, such as Nigeria, organisations make substantial use of technology. In others, such as the Solomon Islands, they do not. The key factors mediating this appear to be the availability of communications infrastructure, local culture and donor priorities. None of 
the respondents idealised technology, and many emphasised that analogue communications are still relevant in their context. Flyers stir hostilities in Zanzibar markets; newspapers distort information in Nigeria. In the Solomon Islands, word of mouth is still a critical form of information exchange, given the low penetration and prohibitively high costs of modern telecommunications:

Not everyone has a radio. A newspaper costs 5 dollars-two packets of noodles. When people don't get information, they create their own information. And the coconut wireless is much faster than the mobile phones.

(RAMSI representative, Solomon Islands)

Generally, faith-based organisations were discerning in their use of technology, recognising when it helped and hindered. In some cases, respondents were wary because of instances in which technology has helped to incite violence by spreading rumours:

After [recent youth violence] we asked what caused the problem? The youth said rumours. This is the disadvantage of technology. The illiterate, semi-literate don't have the sense or time to say this sort of rumour is not true, or let me verify it. They just react.

(Muslim faith leader, Nigeria)

However, faith-based organisations are not invulnerable to technological misadventures either. One organisation ran a successful conflict early warning initiative based on monitoring teams comprised of local volunteers, who were able to refer issues to the organisation for early mediation. Based on this, an international donor offered to sponsor a technology-enhanced project whereby local people could report incidents by SMS, which could then be plotted on a GPS map in an incident room. Before long, the project became redundant — an expensive duplication of the existing initiative but requiring additional technical skill that few in the organisation had mastered.

\subsection{Short-Termism}

Where faith-based actors are reliant on donor funding, they are subject to the same timing issues encountered by other organisations. Often though, faith-based organisations have access to their own resources, which enables them to engage reflexively over a longer period of time. In the case studies, faith groups ran some activities that were intentionally short-term and operational, but much of their work was also structural, designed to break the cycle of violence over generations. Moreover, when respondents were asked about their perspective on timing, their call was not to speed up, but to slow down, and to invest in long-term initiatives that lay the foundations of peace:

To me, [conflict] prevention sounds like an immediate solution, but actually we need to do our homework. A whole generation has grown up with hatred in their hearts, in their families and communities. So we need to pay more attention there.

(Christian faith leader, Nigeria)

\section{Conclusions}

There has been a demonstrable "turn" to both religion and the local in recent years. This article investigates actors in both of these domains of conflict prevention, who in this case overlap, in order to question some of the conventional assumptions about prevention that emerge from its roots in liberal peace.

Having documented faith-based conflict prevention initiatives in three countries, this article has argued that in some cases they appear to make a meaningful impact in reducing violence. However, to what extent can the successes of local faith-based organisations be attributed to their localness, their faith-basis or both? Clearly, there are instances where localness is key, as this enables organisations to "read" situations and respond appropriately. However, there are also instances where an organisations' religious character can play a decisive role-for instance, in persuading former combatants to give up 
their weapons and be spiritually cleansed. Ultimately, the organisations in the study had both local capital and spiritual and religious capital and used them both.

In some ways, the faith-based approaches studied here conform with "liberal peace" wisdom, as they affirm the fundamental soundness of investing in conflict prevention through peacebuilding initiatives and the practical gains that can be made. This is unsurprising, as they exist within a wider liberal framework and use many of the same models and approaches. Faith-based approaches also provide some useful counterpoints, highlighting liberal peace's susceptibility to quick wins, formulas and technological solutionism. These are serious weaknesses within the liberal peace framework, identified through existing critiques, but none are insurmountable. Indeed, they could all be addressed through reform of the liberal peace agenda, or failing this, could be partially offset by adaptations in current programming. Faith-based approaches offer glimpses of such adaptations, many of which could be replicated by others. Firstly, they foreground values such as justice, compassion and human flourishing. For faith-based actors these values are religiously inspired, but they are also universal values that the wider peacebuilding sector can seek to engender. Secondly, faith-based approaches emphasise the importance of relationships, recognising their significance in explaining people's behaviour and motivation for change. This is habitual for many faith traditions, which stress relationality and the common good, but contrasts with the liberal peace view of the individual as self-governing. Thirdly, faith-based approaches allow participants to engage deeply, bringing in different dimensions of their experience, including spirituality and emotion.

Expanding our view of conflict prevention to include faith-based actors also addresses a methodological blind spot. Generalisations about conflict prevention are becoming more commonplace as the field develops, but they cannot hold true unless they capture the entirety of the endeavour, including initiatives that are faith-based, secular and hybrid. Faith-based initiatives require us to think about peacebuilding vernacular and how far it does and does not travel, and in so doing, it reminds us to scrutinise how accurately and strategically actors use the term "conflict prevention" in general.

The case study approach used in this article was adopted as a first step to exploring a largely unresearched topic. Based on its findings, several pathways for future research have emerged. A theological exploration of the underpinnings and expressions of conflict prevention norms in different faith traditions would add another dimension to existing insights. The current research has also focused on faith-based actors at the leadership level, but what about ordinary religious people? As one respondent would have it, "Many people have no sympathy for dialogue or prevention, they are not theologically convinced. We see the same faces in dialogues, they are interfaith practitioners. What about ordinary people, what theological basis do they have?" (Muslim faith leader, Zanzibar). Is this true, and if it is, does it matter? Finally, another dimension to explore lies in the differences between faith-based conflict prevention and countering violent extremism initiatives, which also involve religious groups in preventative actions. Would the two concepts provide similar insights into the liberal and the local, and if not, how would they differ?

Funding: This research was funded by the UK's Economic and Social Research Council through the Faith-based conflict prevention and early warning scoping project, grant number ES/L002116/1. The APC was funded by RCUK through a block grant to Coventry University. The Zanzibar Case Study was funded through Making All Voices Count, an initiative supported by the UK Department for International Development (DFID), the US Agency for International Development (USAID), the Swedish International Development Cooperation Agency (SIDA) and the Omidyar Network, and implemented by a consortium consisting of Hivos, IDS and Ushahidi.

Acknowledgments: Organisations that have contributed to the projects underpinning this research include the Anglican Alliance (UK), the Archbishop of Canterbury's Reconciliation Ministry (UK), the Action Support Centre (South Africa), Local Peace Committees in Gauteng Province (South Africa), People's Voice for Peace (Uganda) and the Zanzibar Interfaith Centre (Tanzania).

Conflicts of Interest: The author declares no conflict of interest. The funders had no role in the design of the study; in the collection, analyses, or interpretation of data; in the writing of the manuscript; or in the decision to publish the results. 


\section{References}

Abu-Nimer, Mohammed. 2003. Non-Violence and Peacebuilding in Islam: Theory and Practice. Gainesville: University Press of Florida.

Ager, Joey, Elena Fiddian-Qasmiyeh, and Alastair Ager. 2015. Local faith communities and the promotion of resilience in contexts of humanitarian crisis. Journal of Refugee Studies 28: 202-21. [CrossRef]

Aggestam, Karin. 2003. Conflict Prevention: Old Wine in New Bottles? International Peacekeeping 10: 12-23. [CrossRef]

Anderson, Mary B., and Marshall Wallace. 2012. Opting Out of War: Strategies to Prevent Conflict. Boulder: Lynne Rienner Publishers.

Appleby, R. Scott. 2000. The Ambivalence of the Sacred: Religion, Violence and Reconciliation. Lanham: Rowman and Littlefield Publishers.

Appleby, R. Scott. 2015. The new name for peace? Religion and development as partners in strategic peacebuilding. In The Oxford Handbook of Religion, Conflict and Peacemaking. Edited by Atalia Omer, Appleby R. Scott and David Little. New York: Oxford University Press.

Baker, Chris. 2009. Blurred encounters? Religious literacy, spiritual capital and language. In Faith in the Public Realm: Controversies, Policies and Practices. Edited by Adam Dinham, Robert Furbey and Vivien Lowndes. Bristol: Polity Press.

Bercovitch, Jacob, and S. Ayse Kadayifci-Orellana. 2009. Religion and Mediation: The Role of Faith-Based Actors in International Conflict Resolution. International Negotiation 14: 175-204. [CrossRef]

Boege, Volker, Anne Brown, Kevin Clements, and Anna Nolan. 2009. Building peace and political community in hybrid political orders. International Peacekeeping 16: 599-615. [CrossRef]

Bompani, Barbara. 2019. Religion and development: Tracing the trajectories of an evolving sub-discipline. Progress in Development Studies 19: 171-85. [CrossRef]

Bourdieu, Pierre. 1987. Legitimation and structured interests in Weber's sociology of religion. In Max Weber: Rationality and Modernity. Edited by Sam Whimster and Scott Lash. London: Allen and Unwin, pp. 119-36.

Bramsen, Isabel, and Paul Poder. 2018. Emotional Dynamics in Conflict and Conflict Transformation. Berlin: Berghof Foundaton.

Cavanaugh, William T. 1995. A fire strong enough to consume the house: The wars of religion and the rise of the state. Modern Theology 11: 397-420. [CrossRef]

Cavanaugh, William T. 2009. The Myth of Religious Violence: Secular Ideology and the Roots of Modern Conflict. New York: Oxford University Press.

Chalmers, Malcolm. 2006. Spending to save? The cost-effectiveness of conflict prevention. Defence and Peace Economics 18: 1-23. [CrossRef]

Chandler, David. 2010. The uncritical critique of 'liberal peace'. Review of International Studies 36: 137-55. [CrossRef]

Clarke, Gerald, Michael Jennings, and Timothy Shaw. 2008. Development, Civil Society and Faith-Based Organizations: Bridging the Sacred and the Secular. Basingstoke: Palgrave Macmillan.

Coote, Anna. 2012. The Wisdom of Prevention. London: New Economics Foundation.

De Juan, Alexander, and Jan Henryk Pierskalla. 2014. Civil war violence and political trust: Microlevel evidence from Nepal. Conflict Management and Peace Science 33: 67-88. [CrossRef]

Della-Giacoma, Jim. 2011. Preventative diplomacy in Southeast Asia: Redefining the ASEAN way. In Preventative Diplomacy: Regions in Focus. Edited by Francesco Mancini. New York: International Peace Institute, pp. 28-35.

DfID. 2012. Faith Partnership Principles: Working Effectively with Faith Groups to Fight Global Poverty. London: DfID.

Duff, Jean, Mark Battcock, Azza Karam, and Adam Russell Taylor. 2016. High level collaboration between the public sector and religious and faith-based organizations: fad or trend? The Review of Faith and International Affairs 14: 95-100. [CrossRef]

Galtung, Johan, and Graheme MacQueen. 2008. Globalizing God: Religion, Spirituality and Peace. Germany: Transcend University Press.

Gopin, Marc. 2015. Negotiating secular and religious contributions to social change and peacebuilding. In The Oxford Handbook of Religion, Conflict and Peacemaking. Edited by Atalia Omer, Appleby R. Scott and David Little. New York: Oxford University Press.

Gough, Ian. 2013. The political economy of prevention. British Journal of Political Science 45: 307-27. [CrossRef] 
Guest, Matthew J. 2007. In search of spiritual capital: the spiritual as a cultural resource. In The Sociology of Spirituality. Edited by Keiran Flanagan and Peter C. Jupp. Aldershot: Ashgate, pp. 181-200.

Haider, Huma. 2016. Religious leaders and the prevention of election violence. GSDRC Applied Knowledge Services Helpdesk Research Report. Available online: https://gsdrc.org/wp-content/uploads/2016/07/HDQ1366.pdf (accessed on 3 April 2020).

Haufler, Virginia. 2004. International diplomacy and the privatization of conflict prevention. International Studies Perspectives 5: 158-63. [CrossRef]

Haufler, Virginia. 2010. The Kimberley Process Certification Scheme: An innovation in global governance and conflict prevention. Journal of Business Ethics 89: 403-16. [CrossRef]

Hauge, Wenche, Rachelle Doucet, and Alain Gilles. 2015. Building peace from below-The potential of local models of conflict prevention in Haiti. Conflict, Security and Development 15: 259-82. [CrossRef]

Hay, David. 2000. Spirituality versus individualism: Why we should nurture relational consciousness. International Journal of Children's Spirituality 5: 37-48. [CrossRef]

Haynes, Jeffrey. 2011. Religion, Politics and International Relations: Selected Essays. London: Routledge.

Hayward, Susan. 2015. Women, Religion, and Peacebuilding. In The Oxford Handbook of Religion, Conflict and Peacemaking. Edited by Atalia Omer, Appleby R. Scott and David Little. New York: Oxford University Press.

Hayward, Susan, and Katherine Marshall. 2015. Women, Religion, and Peacebuilding: Illuminating the Unseen. Washington: United States Institute of Peace Press.

Heelas, Paul L. F. 2002. The spiritual revolution: From 'religion' to 'spirituality'. In Religions in the Modern World. Edited by Linda Woodhead, Paul Fletcher, Kiroko Kawanami and David Smith. London: Routledge, pp. 357-77.

Hertog, Katrien. 2010. The Complex Reality of Religious Peacebuilding: Conceptual Contributions and Critical Analysis. Plymouth: Lexington Books.

Jacobsen, Katja Lindskov, and Troels Gauslå Engell. 2018. Conflict prevention as a pragmatic response to a twofold crisis: Liberal interventionism and Burundi. International Affairs 94: 363-80. [CrossRef]

Jeffrey, Renée, and Caitlin Mollica. 2017. The unfinished business of the Solomon Islands TRC: Closing the implementation gap. The Pacific Review 30: 532-48. [CrossRef]

Johnston, Douglas, and Cynthia Sampson. 1994. Religion, The Missing Dimension of Statecraft. Oxford: Oxford University Press.

Johnstone, Naomi, and Isak Svensson. 2013. Belligerents and believers: Exploring faith-based mediation in internal armed conflicts. Politics, Religion \& Ideology 14: 557-79.

Keshodkar, Akbar. 2013. Tourism and Social Change in Post-Socialist Zanzibar: Struggles for Identity, Movement and Civilization. Plymouth: Lexington Books.

Kurtz, Gerrit, and Christoph O. Meyer. 2018. Is conflict prevention a science, art or craft? Moving beyond technocracy and wishful thinking. Global Affairs 5: 23-39. [CrossRef]

Langås, Arngeir. 2019. Peace in Zanzibar: Proceedings of the Joint Committee of Religious Leaders in Zanzibar, 2005-2013. New York: Peter Lang Publishing Inc.

Leach, Steven. 2016. Preventing Violence: Community-Based Approaches to Early Warning and Early Response. Zurich: ETH Zurich.

Leach, Steven, Richard Smith, Chas Morrison, and Laura Payne. 2015. Can ICT Innovation Adequately Support Conflict Prevention? Hivos Blog. January 14. Available online: https://knowledge.hivos.org/can-ictinnovation-adequately-support-conflict-prevention (accessed on 5 June 2019).

Lederach, John Paul. 2001. Five qualities of practice in support of reconciliation processes. In Forgiveness and Reconciliation: Religion, Public Policy \& Conflict Transformation. Edited by Raymond G. Helmick and Rodney L. Peterson. Philadelphia: Templeton Foundation Press, pp. 183-93.

Lederach, John Paul, and R. Scott Appleby. 2010. Strategic Peacebuilding: An Overview. In Strategies of Peace: Transforming Conflict in a Violent World. Edited by Daniel Philpott and Gerard F. Flowers. New York: Oxford University Press.

Lynch, Cecelia. 2015. Religious Communities and Possibilities for Justpeace. In The Oxford Handbook of Religion, Conflict and Peacemaking. Edited by Atalia Omer, Appleby R. Scott and David Little. New York: Oxford University Press.

Mac Ginty, Roger. 2018. The limits of technocracy and local encounters: The European Union and peacebuilding. Contemporary Security Policy 31: 166-79. [CrossRef] 
Mac Ginty, Roger, and Oliver P. Richmond. 2013. The local turn in peacebuilding: A critical agenda for peace. Third World Quarterly 34: 763-83. [CrossRef]

Martin-Shields, Charles. 2013. Inter-ethnic Cooperation Revisited: Why Mobile Phones Can Help Prevent Discrete Events of Violence, Using the Kenyan Case Study. Stability: International Journal of Security and Development 58: 1-13.

Marx, Karl. 1844. Critique of Hegel's Philosophy of Right (Zur Kritik der Hegelschen Rechtsphilosophie), Deutsch-Französische Jahrbücher.

Matveeva, Anna. 2006. Early Warning and Early Response: Conceptual Empirical Dilemmas. The Hague: European Centre for Conflict Prevention.

Mullin, Corinna. 2010. Islamist challenges to the 'liberal peace' discourse: The case of Hamas and the Israel-Palestine 'peace process'. Millennium: Journal of International Studies 39: 525-46. [CrossRef]

Musa, Gerald. 2016. Negotiating mutuality through peace accords: Kaduna State as a case study. Peace and Change 41: 452-74. [CrossRef]

Neumaier, Eva. 2004. Missed opportunities: Buddhism and ethnic strife in Sri Lanka and Tibet. In Religion and Peacebuilding. Edited by Harold Coward and S. Smith Gordon. New York: SUNY Press, pp. 69-92.

Palihapitiya, Madhawa. 2018. Faith-based conflict early warning: Experiences from two conflict zones. The Journal of Interreligious Studies 24: 61-77.

Paris, Roland. 2010. Saving liberal peacebuilding. Review of International Studies 36: 337-65. [CrossRef]

Perchoc, Philippe. 2016. Religious Organisations and Conflict Resolution (PE 593.515). Brussels: European Parliamentary Research Service.

Philpott, Daniel. 2007. Explaining the political ambivalence of religion. American Political Science Review 101: 505-25. [CrossRef]

Putman, Katharine, Julia Lea, and Cynthia Eriksson. 2011. Cross-cultural comparison of religious coping methods reported by native Guatemalan and Kenyan faith-based relief providers. Journal of Psychology and Theology 39: 233-43. [CrossRef]

Putnam, Robert. 2000. Bowling Alone: The Collapse and Revival of American Community. New York: Simon and Schuster Paperbacks.

Richmond, Oliver. 2009. A post-liberal peace: Eirenism and the everday. Review of International Studies 35: 557-80. [CrossRef]

Richmond, Oliver P., and Roger Mac Ginty. 2015. Where now for the critique of the liberal peace? Cooperation and Conflict 50: 171-89. [CrossRef]

Sabaratnam, Meera. 2011. A liberal peace? A brief intellectual history of international conflict management, 1990-2010. In A Liberal Peace? The Problems and Practices of Peacebuilding. Edited by Susanna Campbell, David Chandler and Meera Sabaratnam. London: Zed Books.

Saferworld and Conciliation Resources. 2016. Effective Local Action: From Early Warning Peacebuilding. London: Saferworld and Conciliation Resources.

Sampson, Cynthia, and John Paul Lederach. 2000. From the Ground Up: Mennonite Contributions to Peaecebuilding. Oxford: Oxford University Press.

Shannahan, Chris, and Laura Payne. 2016. Faith-Based Interventions in Peace, Conflict and Violence: A Scoping Study, Joint Learning Initiative for Faith and Local Communities.

Toft, Monica Duffy, Daniel Philpott, and Timothy Samuel Shah. 2011. God's Century: Resurgent Religion and Global Politics. New York: W. W. Norton \& Co.

UNHCR. 2014. Partnership Note on Faith-Based Organizations, Local Faith Communities and Faith Leaders. Geneva: UNHCR.

United Nations and World Bank. 2018. Pathways for Peace: Inclusive Approaches to Preventing Violent Conflict. Washington, DC: World Bank.

Vanheusden, Els. 2010. Overview of the conflict prevention policy of the EU. MICRON Policy Working Paper 16. Brighton: University of Sussex.

Verkoren, Willemijn. 2006. Knowledge networking: Implications for peacebuilding activities. International Journal of Peace Studies 11: 27-62. 
Weber, Max. 1964. The Sociology of Religion. Boston: Beacon Press.

Wulf, Herbert, and Tobias Debiel. 2009. Conflict Early Warning and Response Mechanisms: Tools for Enhancing the Effectiveness of Regional Organisations? A Comparative Study of the AU, ECOWAS, GAD, ASEAN/ARF and PIF. London: LSE.

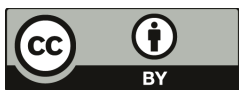

(C) 2020 by the author. Licensee MDPI, Basel, Switzerland. This article is an open access article distributed under the terms and conditions of the Creative Commons Attribution (CC BY) license (http://creativecommons.org/licenses/by/4.0/). 


\title{
Article \\ Religion and Peace-Anatomy of a Love-Hate Relationship
}

\author{
Christine Schliesser ${ }^{1,2}$ \\ 1 Ethics Center Institute for Social Ethics, Zürich University, Rämistrasse 71, 8006 Zürich, Switzerland; \\ christineschliesser@gmail.com \\ 2 Violent Histories and Transgenerational Trauma Research, Stellenbosch University, Private Bag X1, \\ Matieland, 7602 Stellenbosch, South Africa
}

Received: 25 March 2020; Accepted: 23 April 2020; Published: 29 April 2020

\begin{abstract}
Human history is filled with numerous examples—-both past and present-that make religion and violence appear to be best friends. Ever since the events surrounding 9/11, religiously inspired violence has been considered one of the most pressing issues of our times (cf. Juergensmeyer 2017; Kimball 2008). While the conflictive dimensions of religion are still indisputably at the forefront of public and political attention, religion's significant resources for peace and reconciliation gain increasing attention as well. This contribution will provide an analysis of the love-hate relationship between religion and peace in three consecutive steps. The first part focuses on the role(s) of religion in conflict. Frazer and Owen's six different ways of thinking about religion provide a model for better understanding religion's conflictive sides (Frazer and Owen 2018; cf. Frazer and Friedli 2015). In a second step, this article discusses religion's potent, yet often neglected constructive resources for sustainable peace. While taking into account the vast diversity of religious actors, certain content-based and formal characteristics emerge that help to shed light on the otherwise vague "religious factor" in peacebuilding. Finally, an example taken from post-genocide Rwanda will serve to illustrate the preceding discussion.
\end{abstract}

Keywords: religion; peace; conflict; peacebuilding; FBO; conflict resolution; conflict analysis; development; post-genocide Rwanda; CARSA

\section{Introduction}

Human history is filled with numerous examples—-both past and present-that make religion and violence appear to be best friends. The events surrounding 9/11 brought religiously inspired violence to the vanguard as one of the most pressing issues of our times (cf. Juergensmeyer 2017; Kimball 2008). While the conflictive dimensions of religion are still indisputably at the forefront of public and political attention, religion's significant resources for peace and reconciliation gain attention as well. The increasing interest in the constructive role of religion in processes of social change is embedded in a larger-scale development regarding the recognition of religion in public issues. For decades, Max Weber's pronouncement of a "disenchantment of the world", coupled with the post-Enlightenment relegation of religion to the private realm, had dominated the perception of religion in Western societies. Recent years, however, have seen the beginnings of a paradigm change. Religion sociologist Peter $\mathrm{L}$. Berger even speaks of a "desecularization of the world" (Berger 1999). This assessment is supported by recent findings of the Pew Research Center, predicting that the 21st century will be a religious one 
with almost all major religions gaining new members. ${ }^{1}$ While Nicos Mouzelis points to "choice" as a "key element for understanding the present and future religious landscape" (Mouzelis 2012, p. 220) that is apparent in all three main features of modernity, namely the massive inclusion into the center, top-down differentiation and overall individualization, this sociological perspective neglects religion-immanent features from within their respective theologies as significant factors shaping both religions' self-understanding and their perception from the outside. ${ }^{2}$ Policy makers, academics and practitioners have therefore started to pay closer attention to the significance of religion and the roles of religious actors in public issues and processes of social change.

Indicative of this increasing interest is the Plan of Action for Religious Leaders and Actors, launched by UN Secretary-General Guterres in July 2017. It includes the following proposal: the United Nations should "establish a world forum of religions and beliefs that would bring together an equal representation of religious leaders and actors, policy makers, educators, and media personnel from all world regions. The forum would deliberate on the role of religions in enhancing peaceful, inclusive, and just societies. The forum would have regional hubs" (Plan of Action 2017). The plan not only points to the significance of religion in constructively addressing global challenges such as peace and justice, but also to the necessity of both a global perspective and local roots or "hubs".

While the acknowledgement and appreciation of the roles of religion in global issues are long overdue, religion is no panacea. Religion is innately ambiguous and can be employed to draw out both the best and the worst in humankind. This holds especially true with regards to peace and conflict. This contribution provides an analysis of the love-hate relationship between religion and peace in three consecutive steps. A first part focuses on the roles of religion in conflict. Owen Frazer and Mark Owen's six different ways of thinking about religion provide a model for better understanding religion's conflictive sides (Frazer and Owen 2018; cf. Frazer and Friedli 2015). In a second step, this article discusses religion's potent, yet often neglected constructive resources for sustainable peace. While taking into account the vast diversity of religious actors, certain content-based and formal characteristics emerge that help to shed light on the otherwise vague "religious factor" in peacebuilding (cf. Schliesser et al. forthcoming). In a third and final part, an example taken from post-genocide Rwanda will illustrate the preceding discussion.

\section{Religion and Conflict-Six Ways to Better Understand Their Relationship}

In the past decade, the number of conflicts with a religious dimension have increased substantially. While in 2007 about $20 \%$ of countries world-wide experienced conflicts in which religion played a role, only ten years later the number had increased to $25 \%$ (Pew Research Center 2018). At the same time, there is wide-spread unclarity as to what in fact constitutes "religious violence". One problem connected with this term is that it might lead to the misunderstanding as if religion were the main or even sole driving force behind a certain conflict. Rather, conflicts always have multiple dimensions, including economic, political and social factors. Second, as of now, "no universally accepted definition of religion or faith exists" (Ware et al. 2016, p. 324). Yet, if it is not clear what exactly constitutes "religion", "religious violence" remains equally opaque. For the purpose of this contribution, I will employ a constructive-pragmatic concept of religion. This means understanding as "religion" what is described as "religion" by interlocutors and communities in a given context (Waardenburg 1986). A third problematic factor connected to the term "religious violence" is a potentially one-sided

1 The Pew Research Report 2015 indicates that all major religions, with the exception of Buddhism, will increase in membership. By 2050, the number of Muslims worldwide will match the number of Christians. In Europe, $10 \%$ of the population will be Muslims (Pew Research Center 2015).

2 In Christian theology, for example, the paradigm of "Public Theology" has been gaining increasing attention as it emphasizes the relevance of both theology for public issues and public issues for theology (cf. Storrar and Morton 2004). For a more sceptical view on the question of a "return of religion" (cf. Wilson 1982 and Martin 2005). 
legitimation of violence by insinuating that "religious" violence is always irrational and fanatical and must be contained by "secular" violence which is always rational and controlled (cf. Cavanaugh 2004).

Conflict analysis tends to shy away from the consideration of religion. The "religious factor" is either deemed irrelevant and therefore neglectable or too complex to be of any real use. The first perspective ignores a sometimes fundamental aspect in the analysis of a conflict, while the second perspective neglects the fact that religion is often tied to different dimensions that each impact a conflict in a certain way and that can be clearly differentiated. In the following, I will outline six different ways of how religion might function within a given conflict. ${ }^{3}$ These six dimensions are not mutually exclusive, but rather any conflict is likely to display several of them. At the same time, these different ways of thinking about the role of religion do not have clear-cut boundaries, but canoverlap at times. Like religion, each aspect is ambiguous in and of itself; it can serve to create division and strife, while it also contains potent resources for overcoming hatred and for building peace.

\subsection{Religion as Community: Authorities, Relationships and Identities}

Thinking about religion as community is central to the approach of French sociologist Émile Durkheim (1858-1917). Religion, according to Durkheim, is "a unified system of beliefs and practices ... which unite into one single moral community called a Church, all those who adhere to them" (Durkheim 1915, p. 47). Next to other aspects, it is the integrative function of religion that is emphasized here and its ability to build relationships and communities. Durkheim and his followers in the structural functionalist approach are interested in the way religion establishes and supports structures and institutions in society, including the family and the state. This includes the establishment of authorities both in the temporal and spiritual arena. As such, religion serves the stabilization or attestation of a given community.

Connected to religion's role in establishing communities is its significance in creating identities, both in a personal and a collective sense. By belonging (or not belonging) to a certain community, by adhering (or not adhering) to the required social and moral codes, senses of the self are being constructed and affirmed. In conflict, the community and identity forming aspects of religion are highly relevant. In times of upheaval, belonging to a community can provide reassurance and stability. At the same time, the self-identification with a community and the obedience to its authorities tend to foster an in-group/out-group mentality. Religion as community thus becomes a boundary marker of who belongs and who does not. This becomes especially problematic when this boundary marker is connected with other concepts such as nationhood. India's current Hindu-nationalist agenda, for instance, illustrates how the religious boundary marker "Hindu" becomes synonymous with that of "being Indian". While political strategies like these usually serve to strengthen national coherence, they often result in conflicts with religious minority groups who feel discriminated by religiously defined concepts of the nation.

\subsection{Religion as a Set of Teachings: Concepts, Norms and Values}

Religion can also be viewed as a set of teachings. These inherited teachings often contain dogmatic aspects, i.e., what to believe, from which ethical dimensions follows, i.e., how to act. The contents of a set of teachings are the focus of a "substantial" understanding of religion, rather than a "functional" perspective displayed by Durkheim and others (cf. Werkner 2016). In the Abrahamic religions, these teachings are collected in their respective Holy Scriptures, Torah, Bible and Quran (as well as traditions of law deriving from various sources such as the Jewish Halacha and Islamic Sharia), while other religious traditions rest primarily on oral rather than on written narratives. Religious sets of teachings are regarded as divine inspiration and serve not only to make sense of life, but they

3 For this, I will combine the approaches of Frazer and Friedli (2015) and Frazer and Owen (2018), who each point to different dimensions of religion in conflicts (cf. Schliesser et al. forthcoming). 
also offer clear guidance and instructions on how to behave. This shared understanding can help to increase social cohesion, yet it can also lead to othering by creating insiders and outsiders.

Understanding religion as a set of teachings that includes fundamental concepts and normative implications also means taking the inherent ambiguity of religion into consideration. Religious teachings can be used for peace and for war. While religiously motivated peace-makers often refer to Scripture as their orientation and motivation (cf. Little 2007), the same holds true for Islamist suicide bombers (cf. Kruglanski et al. 2009). A common ideal such as peace and justice can become a powerful driving force for interreligious dialogue and cooperation, working together for the same goals from different religious foundations. At the same time, religious concepts and values can be used to confront the powers-that-be. Much of the social and political criticism of, for instance, South American Liberation Theology stems from a specifically Christian understanding of justification and justice (Boff and Boff 1987).

\subsection{Religion as Spirituality: Personal Experience, Motivation and Meaning}

Religion has a spiritual dimension that has bearings on peace and conflict situations. The spiritual dimension refers to the personal experience of faith as it plays out in certain life styles and behavioral choices. These can be set in both an individual or a collective context, such as in a monastery, an ashram or a Sufi circle. The World Conference of Religions for Peace defines spirituality broadly as "an awareness of responsibility rooted in an ultimate concern" (Jack 1980). This "awareness of responsibility" can be a powerful motivator. It inspired, for instance, Gautama Buddha's engagement to challenge the Brahmin-priests' authority and the caste system in general. While being rooted in the inner self, religious spirituality can become the catalyst for far-reaching external action that can be both promoting and diffusing conflict. At the same time, shared spiritual experiences (meditations, worship, Scriptural readings) can serve to create strong bonds between the participants. While this can lead to othering and exclusion ("them" vs. "us"), it can also help to connect across religions or communities.

Next to its motivating function, religion as spirituality also serves to bestow ultimate meaning. Here, the eschatological framework that many religions provide, i.e., the conviction that there is a horizon of meaning that transcends the individual's life span, becomes of importance. Connecting one's own life with its limitations to this larger purpose, coupled with the conviction of "doing God's will", can help to find meaning beyond the individual's experience. Again, the conviction of "doing God's will" can be found in both peacemakers' and in terrorists' rationales.

\subsection{Religion as Practice: Symbols and Rituals}

Religion as practice is the most easily visible aspect of religion. Jewish kippa, Christian church bells or Sufi dancing are all examples of lived religion. Religion as practice refers to how religion is acted out in everyday life, in dress, in food and in different coded forms such as symbols or rituals. All these lend structure and form not only to the cycle of the year (for instance, through Christian markers like Christmas, Lent, Easter, Pentecost, Thanksgiving), but also to the individual's life cycle. Religious rites of passages support the individual in times of transition such as birth, coming of age, marriage and death. Especially in perilous times such as sickness and death, rites de passage provide much needed structure and support.

Duringhighly unsettling times of conflict, adherence to familiar rituals can help in coping with extreme situations. Through joint participation, bonds are created and strengthened, and identities are confirmed. At the same time, symbols and rituals can serve as boundary markers between "us" and "them", highlighting differences and cementing social rifts. While religious rituals are powerful resources for peace, they can also be used for the opposite purpose. One example is the long-standing tradition of 
blessing arms, including weapons of mass destruction, as is being practiced by the Russian-Orthodox Church. Only recently, criticism of this ritual has been voiced from within the Church. ${ }^{4}$

\subsection{Religion as Discourse: Language, Power and Weltanschauung}

The term discourse is used in a wider sense here. Not only does it encompass semantics and communication, but religion as discourse refers to a specific interpretation of reality. As George Lindbeck puts it, religion in this sense is "a kind of cultural and/or linguistic framework or medium that shapes the entirety of life and thought" (Lindbeck 1984, p. 33). It is this Weltanschauung, in which a certain use of language makes sense. In situations of conflict, it may be the case that actors use religious language that depends on the interpretative context of their own system. For instance, the term "gender equality" could mean something entirely different in different thought systems. In order for genuine communication to take place, the dependency of language on a particular interpretative framework must be recognized and special effort must be undertaken to provide translations that help to convey the intended meaning.

Understanding religion as discourse also draws attention to power structures. The interpretative authority often rests with religious authorities. Alternative readings may or may not be allowed. A recent study points to the correlation between the legitimacy of different meanings of a given term and conflictive situations (Ochs et al. 2018). Those perceived to have authority within a given framework can use their influence for purposes of peace, such as Pope John XXIII in his influential encyclical Pacem in terris (1963), or to incite violence and conflict, such as some Catholic priests during the Rwandan genocide (cf. Rittner et al. 2004).

\subsection{Religion as an Institution: Leadership, Networks and Service Delivery}

Similar to religion as practice, religion also becomes visible in their institutionalized forms. Religious institutions are at home on different levels, reaching from local congregations to regional and national organizations and even international networks. Religious institutions are often engaged in a variety of service deliveries, including education, health services and provision of food and emergency aid when needed. This becomes especially pertinent in times of conflict, when the extended networks of religious institutions prove a reliable support for people in need. As Nobel Peace Prize Laureate Denis Mukwege puts it in view of his native DR Congo, a failed state haunted by corruption and violent conflict since decades: "My hope lies with the churches. When the state fails, the churches still care for the people." ${ }^{5}$ With their detailed knowledge of the local context and culture and their ability to reach even remote areas, religious institutions can become valuable partners on the ground for NGOs such as the UN Blue Helmets. Represented by their leaders, religious institutions can thus contribute to peacebuilding, for instance, by providing services across religious boundaries, yet they can also serve to fuel conflict, not least through sermons inciting hatred and violence towards the religious other.

These six different ways of thinking about religion-as community, as a set of teachings, as spirituality, as practice, as discourse and as institutions-can provide a deeper analysis and clearer understanding of religion's roles in conflict. Throughout, it became apparent that each dimension can play a conflictive and a constructive part, furthering conflict and peace, thereby mirroring the inherently ambiguous nature of religion itself. With the destructive sides of religion usually receiving the bulk of attention, the focus now is on the resources that religion can offer for peace and reconciliation.

4 Russia's Orthodox Church wants priests to stop blessing nuclear weapons, in: New York Post, 5 February 2020, https://nypost. com/2020/02/05/russias-orthodox-church-wants-priests-to-stop-blessing-nuclear-weapons/. Last accessed 30 March 2020.

5 Interview by the author with Denis Mukwege, Bukavu, DR Congo, 6 February 2018. 


\section{Religion and Peace: An Underestimated Partnership}

The relationship between religion and peace is de facto much better than its reputation. Nevertheless, religious peacemaking still operates on the fringes of public acknowledgement, despite the fact that-as Jeffrey Haynes rightly points out_-"religious groups ... have recently and collectively increased their peacemaking efforts" (Haynes 2007, p. 69). As the focus is shifting, however, on the side of academics, policy makers and practitioner towards an increased recognition and acknowledgement of religion's contributions to peace (cf. McDonagh and Network 2019), the need for more systematic analysis becomes more urgent. What exactly are religion's contributions to peace? Any attempts at a systematic examination of the "religious factor" in peace, including peacemaking and peacekeeping, need to take into consideration not only the inherent ambiguity of religion itself, but also the vast plurality of religious actors and Faith-Based Organization (FBOs). ${ }^{6}$ Ron Sider and Heidi Unruh distinguish between six different types of FBOs working in development, ranging from faith-permeated to quasi-secular organizations (Sider and Unruh 2004). Yet, despite this pluralism, it is possible to point to certain characteristics of religious actors (cf. Schliesser 2020). In the following, I present a model for systematization that rests on the differentiation between "formal" and "material" characteristics, while acknowledging that certain overlap is possible (cf. Schliesser et al. forthcoming). The characteristics presented are meant to be representative rather than exhaustive. As with the six dimensions, to which they are being related, each one of the following characteristic is ambiguous in the sense that it can be used for both peaceful and for conflictive purposes.

\subsection{Formal Contributions of Religious Actors to Peace}

\subsubsection{Trust (Religion as Community, Religion as Practice)}

Religious leaders are often perceived as credible and moral authorities, thus generating trust, an essential component for building peace in a volatile environment. The Trust in Institutions Index of 2019 found that in Africa, for example, it is religious leaders who enjoy the highest trust (72\%) (Trust in Institutions Index 2019). Trust within a religious community is further deepened as activities such as bible or Quran studies, youth groups or women's meetings serve to strengthen community cohesion. Next to the community dimension, it is religion as practice that plays a role. Service deliveries within a certain community such as the provision of food, health care or education, have established long-term bonds of trust that can be relied on in times of crisis.

\subsubsection{Relationships and Identity (Religion as Community)}

Their ability to inspire trust is linked to an oftentimes remarkable talent of religious peacebuilders to build relationships and to connect with people, even across religious or other boundaries. "Religious leaders are uniquely positioned to foster nonviolent conflict transformation through the building of constructive, collaborative relationships within and across ethnic and religious groups for the common good of the entire population of a region" (Appleby 2008, p. 127). Due to the trust they enjoy, religious peacebuilders often function as "connectors" between different groups, a crucial ability in peace building processes that rely on the dissemination and acceptance of new ways of thinking, for instance, in terms of reconciliation and forgiveness rather than hatred and revenge. ${ }^{7}$ At the same time, relationships are innately connected to the way we understand ourselves and to the construction of our identity. In peace-making, this becomes of significance as a person's identity can be defined by

6 With Berger (2003, p. 1), I understand FBOs as "formal organizations whose identity and mission are self-consciously derived from the teachings of one or more religious or spiritual traditions and which operate on a non-profit, independent, voluntary basis to promote and realize collectively articulated ideas about the public good at the national or international level".

7 In this regard, social network analysis has been found helpful in better understanding how religious peacebuilders function as "connectors" between so-called "strong-ties groups" (close-knit communities such as religious communities) and "weak-ties groups" (loosely connected groups such as a social media group) (cf. Gopin 2009). 
means of othering, i.e., in opposition to the other, or in terms of a sense of shared identity, for instance, through shared communal activities (Kadayifci-Orellana 2017).

\subsubsection{Moral Influence and Leadership (Religion as a Set of Teachings, Religion as an Institution)}

The trust and credibility religious leaders enjoy also relates to their alleged status as moral authorities. This is not least due to the perception that religious actors are neutral in the sense that they do not seek their own personal advantage, but are committed to the cause only (Bouta et al. 2005). In their position as moral authorities, religious leaders act as influencers. By shaping social values, for instance, compassion or responsibility, they impact thoughts and behavior. Their accepted guidance provides a sense of stability and reliability especially in times of upheaval. Through formal statements such as sermons, but also through their everyday behavior, trusted religious leaders serve as important role models for their communities and can lead the pathway to peace and reconciliation.

\subsubsection{Networks (Religion as an Institution)}

"Why work with religious communities?" asks UNICEF (UNICEF 2017). As one reason, UNICEFpoints to their extensive networks. "With religious communities counting almost 5 billion members, their potential for action is great. From the smallest village to the largest city, and from districts and provinces to national and international levels, they offer a variety of networks for the care and protection of children" (UNICEF 2017). While focused on children, UNICEF's statement can be easily applied to other realms of development, including peace and conflict transformation. Religious actors can rely on extensive regional and transregional networks that enable them to quickly mobilize additional financial and human resources. With their grassroots foundation, religious networks are furthermore able to access even remote areas, all significant requirements for successful and sustainable conflict prevention and conflict transformation.

\subsubsection{Provision of Service Delivery (Religion as a Set of Teachings, Religion as Practice, Religion as Spirituality)}

For many religions, caring for the poor and marginalized is an integral part of their belief system. Well-known religious narratives like the Good Samaritan (Luke 10:25-37) encourage a spirit of empathy and willingness to help others, even strangers and at costs to oneself. Service delivery thus becomes part of one's spirituality that is acted out in specific practices. These include food provision, clean water, refugee services, microfinance, education or medical services, which become especially urgent in times of crisis. In their service delivery, FBOs do not necessarily differ from secular NGOs, with whom they often cooperate, yet for religious actors, the mode of interpretation and motivation stems from within a specifically religious framework. For many religious traditions, giving alms to the needy and/or tithing are central aspects of their own religious self-understanding and spirituality.

\subsection{Material Contributions of Religious Actors to Peace}

\subsubsection{Values and Normative Concepts (Religion as a Set of Teachings, Religion as Practice)}

Religious traditions contain not only dogmatic truth claims, but also ethical imperatives regarding what is viewed as right and wrong. These are based on values and certain normative concepts regulating everyday action and behavior. Many religions regard life itself as a gift by God which means that efforts must be taken to protect one's own and other people's lives from harm. As the German pastor and Nazi resistance fighter Dietrich Bonhoeffer (1906-1945) puts it: "Since by God's will human life on earth exists only as bodily life, the body has a right to be preserved for the sake of the whole person" (Bonhoeffer 2005, p. 185). Based on this premise, Bonhoeffer deduces the necessity of basic human rights as normative concepts. From life itself as a fundamental value, other values follow, such as compassion, justice, peace and reconciliation. Multiple narratives and teachings in different religions serve the dissemination and strengthening of these values. "Religious communities have developed structures and defined relationships shaped by these values, and their belief systems 
encourage efforts to speak out on behalf of and assist the disadvantaged, marginalized and vulnerable" (UNICEF 2017).

\subsubsection{Holistic Anthropology (Religion as Discourse, Religion as Spirituality)}

With secular NGOs often focusing on the material improvement of individuals and communities, FBOs bring in a holistic perspective. Based on their distinct anthropology, they seek to provide support not only to the body, but also to the soul. Connecting the material and spiritual, the physical and the emotional, religious actors embrace a holistic understanding of human flourishing. The significance of assisting not only the body, but also the heart and soul of people becomes apparent, for instance, in post-conflict situations such as in post-genocide Rwanda. Here, religiousactors such as Christian churches or FBOs often combine reconciliation with development initiatives. In the small town of Remera, the Presbyterian Church, for example, supports the "Lights". This group helps perpetrators and survivors through building long-term relationships with one another. These processes are supported by regular bible studies and meetings where issues of healing, forgiveness and dealing with the past are addressed. At the same time, pairs of survivor and perpetrator receive practical support, for instance, through apple saplings. By caring jointly for the saplings and splitting any income they generate, they are not only able to improve the material situations of themselves and their families, but in their daily interactions, empathy, trust and reconciliation can start to grow. Welcome synergetic effects thus help to improve the sustainability of both religious peace and development work.

\subsubsection{Dealing with Trauma and Meaning (Religion as a Set of Teachings, Religion as Spirituality)}

Experiences of violent conflict are traumatic. While physical scars are clearly visible signs of the violence and injustice suffered, emotional wounds often remain hidden. Yet, if they are not attended to, they tend to fester, cementing feelings of powerlessness and insignificance and/or hatred and desire for revenge, thereby perpetuating the spiral of violence. Survivors of gross human rights violations often struggle with integrating these experiences into their life story, in other words, with finding meaning. Here, religious frameworks can provide valuable assistance. The conviction of ultimate justice and redemption helps individuals to connect their own personal life story to the larger eschatological framework, which can impart hope and meaning to traumatized victims. At the same time, religious concepts such as forgiveness and grace help in dealing with feelings of shame, guilt and failure, emotions inevitably occurring in contexts of violent conflict and affecting both victims and perpetrators. In Islam, for instance, concepts such as predestination and the total sovereignty of God together with the values of respecting others and reestablishing order and harmony can help to facilitate processes of healing and reconciliation (Abu-Nimer and Kadayifci-Orellana 2008).

\subsubsection{Rituals (Religion as Practice, Religion as Spirituality)}

It is only recently that the significance of rituals for peace has been explored in more detail (cf. Schirch 2015). On the one hand, rituals help to structure daily life. They provide routine and stability, which in times of unrest, become of high importance. On the other hand, rituals are rich in symbolism and rely primarily on nonverbal methods of communication. As such, they are able to access parts of the person that mere rational approaches cannot reach. Rituals, symbols and other coded non-verbal expressions can thus be helpful in dealing with post-traumatic experiences by creating openings for dealing with the past and for reconciliation. Religious actors have employed, adapted and newly created rituals to structure the path to healing. Catholic communities in Rwanda have, for instance, creatively utilized the Christian sacrament of penance. By means of the ritualized process of the gacaca nkirisitu (Christian gacaca), perpetrators and survivors are led and accompanied on the road to reconciliation (Carney 2015). 


\section{Religion and Peace in Post-Genocide Rwanda: The Example of CARSA's Cows for Peace Project}

In order to illustrate the above discussion, I will utilize the example of the Christian FBO CARSA (Christian Action for Reconciliation and Social Assistance) and their innovative Cows for Peace project (www.carsaministry.org). Faced with the aftermath of the 1994 genocide and struggling to deal with his own losses, Christophe Mbonyingabo founded CARSA in 2004, a local FBO "which aims to support communities in Rwanda in their journey towards healing, forgiveness, reconciliation and holistic development" (CARSA Christian Action for Reconciliation and Social Assistance). Mbonyingabo developed the idea to present pairs of survivor and perpetrator with a cow. This valuable gift not only improves the material situation of survivors, perpetrators and their families, but through the joint care of the animal, pathways for healing and reconciliation are opened up. Regular meetings and bible studies accompany the process. Meanwhile, this project has found numerous emulators throughout the country and it serves well to illustrate the different dimensions of religious peace work.

Religion as Community. Though retaining its independence from established churches, CARSA's Cows for Peace project is firmly situated within a Christian context. Perpetrators and survivors, who have been presented with a cow, come together for regular meetings. CARSA staff lead the group in prayer, bible readings and discussions, yet there is room for informal exchange as well. The structured setting of the meetings helps to create bonds between former enemies. Over time, a group feeling and group solidarity develops that supports positive changes in interpersonal relationships. Trust and even friendship grow as shattered identities are being rebuilt.

Religion as a Set of Teachings. During their regular meetings, CARSA staff emphasize Christian concepts, norms and values such as forgiveness, grace and personal transformation. Corresponding quotes from the Bible, such as Matt 6:12 ("And forgive us our trespasses, as we forgive those who trespass against us") or Matt 18:21-35 (Parable of the Unforgiving Servant) help to reiterate the importance of forgiveness and reconciliation. The ethical dimensions of religious teachings are thus encountered as pertaining to one's own individual life.

Religion as Spirituality. The spiritual dimension of religion connects to the participants' personal life and experiences. Spiritual activities such as prayer, worship and Bible meditation have a firm place in CARSA's approach. Both survivors and perpetrators can find here an outlet for destructive emotions such as shame, guilt or hatred. In a culture that frowns upon the public display of sorrow-as expressed by the saying "The tears of a man go to his belly" — spiritual activities as the ones accompanying the Cows for Peace project can offer a way to deal with individual trauma and loss of meaning.

Religion as Practice. In a country in which more than $90 \%$ of the population adhere to the Christian faith, CARSA can link its activities to a general Christian setting as expressed, for instance, in weekly church services and regular church activities. Yet, by means of creatively using Christian symbols and by creating new rituals, CARSA connects the Christian faith more immediately to the experiences and needs of a post-genocide society. The cross as the central Christian symbol, for instance, is employed in a powerful rite de passage, when participants actually nail their personal letters to a wooden artifact, thereby symbolically handing over their grief and longings to Christ.

Religion as Discourse. Due to their often Christian socialization, most participants are familiar with the Christian language and imagery employed by CARSA. This helps to set an atmosphere of familiarity and welcome, serving subtly to create bonds between the participants. As for power structures, CARSA staff are clearly perceived to be in authority, if only derived from their reliance on Biblical authority. At the same time, a self-critical perspective on the part of CARSA is called for, combined with an awareness of the asymmetrical relationships between leader and participants.

Religion as an Institution. While CARSA started out as a small FBO driven by the effort of one individual, it has meanwhile grown to support more than 80 regional groups throughout the country. CARSA earned the trust of its participants through its reliability and service delivery. As apparent in its name, its trademark is the combination of "reconciliation" and "social assistance", of peace work and 
development work. Through its holistic approach, CARSA cares for the body and the soul, offering practical help and spiritual support.

\section{Conclusions}

To sum up, with the role of religion in peacemaking and peacebuilding attracting increasing attention in academia, policy making and practitioning, the above discussion analyzed different dimensions of the often nebulous "religious factor" in both conflict and peace. Structured along formal and material aspects, the contributions of religion to peace processes came into clearer focus. Awareness of the anatomy of the love-hate relationship between religion and peace and of the different dimensions of religion in conflict and in peace facilitates conflict analysis and can help to find openings for the constructive engagement of religious actors on the pathway to sustainable peace and reconciliation. It became clear, however, that just as religion itself, each of its dimensions are ambiguous and can serve either conflictive or peaceful means. Nevertheless, it also became clear that religion matters in both conflict and peace. Rather than ignoring its impact, the different roles of religion need to be clearly analyzed and, where possible, religion's help enlisted in the joint engagement for a more peaceful world. In this vein, CARSA's Cows for Peace Project in post-genocide Rwanda provided a constructive example of religious peacebuilding.

Funding: This research received no external funding.

Conflicts of Interest: The author declares no conflict of interest.

\section{References}

Abu-Nimer, Mohammed, and S. Ayse Kadayifci-Orellana. 2008. Muslim Peace Building Actors in Africa and the Balkans. Peace and Change 33: 549-81. [CrossRef]

Appleby, R. Scott. 2008. Building Sustainable Peace: The Roles of Local and Transnational Religious Actors. In Religious Pluralism, Globalization, and World Politics. Edited by Thomas Banchoff. Oxford: Oxford University Press, pp. 125-54.

Berger, Peter L., ed. 1999. The Desecularization of the World. In Resurgent Religion and World Politics. Grand Rapids: Wm. B. Eerdmans Publishing.

Berger, Julia. 2003. Religious non-governmental organizations: An exploratory analysis. Voluntas: International Journal of Voluntary and Nonprofit Organizations 14: 15-39. [CrossRef]

Boff, Leonardo, and Clodovis Boff. 1987. Introducing Liberation Theology. Wellwood: Burns \& Oates.

Bonhoeffer, Dietrich. 2005. Ethics, (=DBWE 6). Edited by Clifford Green. Minneapolis: Fortress Press.

Bouta, Tsjeard, Ayse Kadayifci-Orellana, and Mohammed Abu-Nimer. 2005. Faith-Based Peace-Building: Mapping and Analysis of Christian, Muslim, and Faith-Based Actors. The Hague: Clingendael Institute.

Carney, Jay J. 2015. A Generation After Genocide: Catholic Reconciliation in Rwanda. Theological Studies 76: 785-812. [CrossRef]

CARSA (Christian Action for Reconciliation and Social Assistance). 2020. Available online: https://www.peaceinsight. org/conflicts/rwanda/peacebuilding-organisations/christian-action-reconciliation-and-social-assistance-carsa/ (accessed on 30 March 2020).

Cavanaugh, William T. 2004. Sins of Omission: What "Religion and Violence" Arguments Ignore. The Hedgehow Review: Critical Reflections on Contemporary Culture 6: 34-50.

Durkheim, Émile. 1915. The Elementary Forms of Religious Life. Translated by Joseph Ward Swain. London: Allen \& Unwin.

Frazer, Owen, and Richard Friedli. 2015. Approaching Religion in Conflict Transformation: Concepts, Cases and Practical Implications. Zurich: Center for Security Studies (CSS), ETH Zurich, Available online: http:/www.css.ethz.ch/content/dam/ethz/special-interest/gess/cis/center-for-securities-studies/pdfs/ Approaching-Religion-In-Conflict-Transformation2.pdf (accessed on 30 March 2020).

Frazer, Owen, and Mark Owen. 2018. Religion in Conflict and Peacebuilding: Analysis Guide. Washington, DC: United States Institute of Peace, Available online: https:/www.usip.org/sites/default/files/USIP_Religion-inConflict-Peacebuilding_Analysis-Guide.pdf (accessed on 30 March 2020). 
Gopin, Marc. 2009. To Make the Earth Whole: The Art of Citizen Diplomacy in an Age of Religious Militancy. Lanham: Roman \& Littlefield.

Haynes, Jeffrey. 2007. Religion and Development. Conflict or Cooperation? New York: Palgrave Macmillan.

Jack, Homer, ed. 1980. Religion in the Struggle of World Community. Paper presented at the Third World Conference on Religion and Peace (WCRP III), Princeton, NJ, USA, August 29-September 7.

Juergensmeyer, Mark. 2017. Terror in the Mind of God. The Global Rise of Religious Violence. Oakland: University of California Press.

Kadayifci-Orellana, S. Ayse. 2017. Religion and Mediation: Strange Bedfellows or Natural Allies? In The Handbook of Mediation: Theory, Research and Practice. Edited by Alexia Georgakopoulos. New York: Routledge, pp. 369-78.

Kimball, Charles. 2008. When Religion Becomes Evil, rev. ed. San Francisco: HarperOne.

Kruglanski, Arie W., Xiaoyan Chen, Mark Dechesne, Shira Fishman, and Edward Orehek. 2009. Fully Committed: Suicide Bombers' Motivation and the Quest for Personal Significance. Political Psychology 30: 341-44. [CrossRef]

Lindbeck, George. 1984. The Nature of Doctrine. London: SPCK.

Little, David. 2007. Peacemakers in Action: Profiles of Religion in Conflict Resolution. New York: Cambridge University Press. Martin, David. 2005. On Secularization: Towards a Revised General Theory. Aldershot: Ashgate.

McDonagh, Philip, and The OSCE Network. 2019. Religion and Security-Building in the OSCE Context. Involving Religious Leaders and Congregations in Joint Efforts. Available online: http://osce-network.net/fileOSCE-Network/Publications/Religion_and_Security-Building_in_the_OSCE_Context_final.pdf (accessed on 30 March 2020).

Mouzelis, Nicos. 2012. Modernity and the Secularization Debate. Sociology 46: 207-23. [CrossRef]

Ochs, Peter, Nauman Faizi, Jonathan Teubner, and Zain Moulvi. 2018. Value Predicate Analysis: A Language-Based Tool for Diagnosing Behavioral Tendencies of Religious or Value-Based Groups in Region of Conflict. Journal for the Scientific Study of Religion 58: 1-21. [CrossRef]

Pew Research Center. 2015. The Future of World Religions: Population Growth Projections, 2010-2050. Available online: http://www.pewforum.org/2015/04/02/religious-projections-2010-2050/ (accessed on 30 March 2020).

Pew Research Center. 2018. Global Uptick in Government Restrictions on Religion in 2016. Available online: https:// www.pewforum.org/2018/06/21/global-uptick-in-government-restrictions-on-religion-in-2016/ (accessed on 30 March 2020).

Plan of Action. 2017. Plan of Action for Religious Leaders and Actors to Prevent Incitement to Violence that Could Lead to Atrocity Crimes. Available online: https://www.un.org/en/genocideprevention/documents/Plan\% 20of\%20Action\%20Advanced\%20Copy.pdf (accessed on 30 March 2020).

Rittner, Carol, John K. Roth, and Wendy Whitworth, eds. 2004. Genocide in Rwanda. Complicity of the Churches? St. Paul: Paragon House.

Schirch, Lisa. 2015. Ritual, Religion and Peacebuilding. In The Oxford Handbook of Religion, Conflict and Peacebuilding. New York: Oxford University Press, pp. 522-24.

Schliesser, Christine. 2020. Conflict Resolution and Peacebuilding. In Routledge Handbook of Religion and Political Parties. Edited by Jeffrey Haynes. London: Routledge, pp. 126-38.

Schliesser, Christine, S. Ayse Kadayifci-Orellana, and Pauline Kollontai. forthcoming. On the Significance of Religion in Conflict and Conflict Resolution, Religion Matters-On the Significance of Religion in Global Issues. Edited by Christine Schliesser, Pauline Kollontai and Ayse Kadayifci-Orellana. London: Routledge Press, vol. 1.

Sider, Ron, and Heidi R. Unruh. 2004. Typology of Religious Characteristics of Social Service and Educational Organizations and Programs. Nonprofit and Voluntary Sector Quarterly 33: 109-34. [CrossRef]

Storrar, William F., and R. Andrew Morton, eds. 2004. Public Theology for the 21st Century. London: T \& T Clark.

Trust in Institutions Index. 2019. Available online: https://thelivinglib.org/index-trust-in-institutions-2019/ (accessed on 30 March 2020).

UNICEF. 2017. Why Work with Religious Communities? Available online: https://www.unicef.org/about/ partnerships/index_60389.html (accessed on 30 March 2020).

Waardenburg, Jacques. 1986. Religionen und Religion. In Systematische Einführung in die Religionswissenschaft. Berlin: De Gruyter.

Ware, Vicki-Ann, Anthony Ware, and Matthew Clarke. 2016. Domains of Faith Impact: How "Faith" is Perceived to Shape Faith-Based International Development Organisations. Development in Practice 26: 321-33. [CrossRef] 
Werkner, Ines-Jacqueline, ed. 2016. Religion in der Friedens- und Konfliktforschung. In Interdisziplinäre Zugänge zu einem multidimensionalen Begriff. Zeitschrift Friedens- und Konfliktforschung, special ed. Baden-Baden: Nomos. Wilson, Bryan R. 1982. Religion in Sociological Perspective. Oxford: Oxford University Press.

(c)

(C) 2020 by the author. Licensee MDPI, Basel, Switzerland. This article is an open access article distributed under the terms and conditions of the Creative Commons Attribution (CC BY) license (http://creativecommons.org/licenses/by/4.0/). 


\title{
Article \\ Religious Engagement and the Migration Issue: Towards Reconciling Political and Moral Duty
}

\author{
Joanna Kulska \\ Institute of Political Science and Administration, University of Opole, Katowicka 89, 45-061 Opole, Poland; \\ jkulska@uni.opole.pl
}

Received: 31 March 2020; Accepted: 7 May 2020; Published: 11 May 2020

\begin{abstract}
The increasingly acknowledged post-secular perspective has resulted in the emergence of some new approaches theorizing this phenomenon. One such approach has been the concept of religious engagement, which calls for the redefinition of the perception of religious non-state actors towards including them as important partners in the process of identifying and realizing political goals. According to this view, due to the multidimensional role played by religious communities and non-state religious actors, they need to be recognized as pivotal in creating a new form of knowledge generated through encounter and dialogue of the political decision-makers with these subjects. Among numerous others, the challenge of migration calls for enhanced debate referring to both political and ethical issues. When such a perspective is applied, the question is raised of the duties and limits of nation-states using more or less harsh political measures towards refugees and migrants based on the concept of security, but also short-term political goals. In the face of a state's lack of will or capacity to deal with the problem of migration, the question of religion serving not only as the service-provider but also as the "trend-setter" with regard to fundamental ethical questions needs to be considered.
\end{abstract}

Keywords: religious engagement; post-secularism; civil society; transformative approach; relational approach; duty dilemma; Humanitarian Corridors; Community of Sant'Egidio

\section{Introduction}

Out of many unexpected, yet decisive dimensions of religion's "come back" in the social-political arena over the last decades, both globally and locally, the revisited relation between "the secular" and "the religious", and as a result, "the political" and "the religious" has emerged. Against the tradition of strict separation of both spheres rooted in the Westphalian-Enlightenment tradition, increasingly visible bridging and even overlapping of both domains has been "discovered" or "rediscovered" (Berger 1999; Philpott 2002; Haynes 2007; Thomas 2005). Following Scott Appleby's ambivalence of religion (Appleby 2000), the "both and" approach referring to "religious and secular", substituting the old "either or" approach, has been postulated by many. Vendulka Kubálková proposes the overcoming of dualism and recognition of coexistence of religion and politics through political theology (Kubálková 2000). Marc Gopin speaks of negotiating religious and secular contributions to social change (Gopin 2015). Erin Wilson suggests relational dialogism (Wilson 2012). Slavica Jakelić conceptualizes secular-religious encounters as peacebuilding (Jakelić 2015).

The idea that the sacred can be part of the secular is one of the Durkheim's most radical and underappreciated claims regarding religion (Barnett 2015). Today, the very categories of the religious and the secular in the public sphere are being revisited, reworked, and rethought (Mendieta and VanAntwerpen 2011). The mentioned reconceptualization does not only refer to some specific areas of common interest in which secular and religious actors have cooperated, but it also applies to mutual recognition of the religious and secular domains as such in domestic and global politics. 
The expression of this recognition has been the influential concept of post-secularism which, though contested (Mavelli and Petito 2014), opens a new space for mutual appreciation and mutual inspiration (Haynes 2016). In the post-secular society, the liberal ethics of citizenship requires from both religious and secular citizens a "complementary learning process" (Habermas 2005). According to this approach, in the post-secular society, believers and non-believers "have cognitive reasons to take seriously each other's contributions to controversial subjects in the public debate" (Ratzinger and Habermas 2006).

Religious-political cooperation emerged first in such traditional crucial areas of religious and faith-based actors' activities as development and humanitarian aid. Soon, the kind of badly needed "symbiosis" was unveiled in the area of conflict resolution and peacebuilding (Johnston and Sampson 1994). As the concept of "peace" has been gradually reconceptualized and broadened, the religious and secular approaches found common ground stressing the relational and transformative dimensions of conflict resolution and peacebuilding (Galtung 2007; Lederach 1999). As a result, religious "thinking" as well an religious "doing" have to a certain extent been transferred to the domains that had been reserved earlier to political decision-makers and referred to as "high politics" (Seiple and Hoover 2004; Johnston 2003; Surmacz 2013). Contribution of religious and faith-based actors, constituting a crucial share of the civil society sector, has thus increasingly been perceived not only as a type of "first-aid", but also as a premise of reshaping the relationship of power and authority of the state in contemporary global politics (Wilson 2014). Eventually, based on the assertion of the critical role of the religious and faith-based actors in improving the level of comprehension and mutual understanding in an increasingly culturally pluralistic and politically fragmented global setting, the concept of religious engagement has been proposed (Appleby et al. 2010; Petito and Thomas 2015; Mandaville and Silvestri 2015).

According to the concept of religious engagement, the role of religious and faith-based non-state actors cannot be reduced to charity and humanitarian aid performed in the international arena. Due to their social but also political capacity, they have to be recognized as partners whose potential not only can, but in fact has to be, considered at the political-making level in the area of foreign policy. The essential contribution that religious communities and non-state actors can make is a new form of knowledge, which is generated through the encounter and dialogue with religious communities and religious actors. The approach is based on the assumption that in the contemporary world, knowledge is constructed from the bottom and not from the top, and thus the bottom layers of the society and not the top ones "can also be the preferential place for epistemology, for discovering what knowledge is, how it is constructed and in whose interests it is constructed" (Petito and Thomas 2015) in the area of global politics. As such, religion needs to also be understood as part of historical progress. The result of the emergence of a new secular-religious partnership is the stretching of political imagination and creating new practical innovations to respond to numerous global challenges (Petito and Thomas 2015; Petito 2019).

Although referring to the religious perspective has not (yet) become a universal pattern, it has gradually been included into the wider discourse in the context of growing significance of civil society initiatives and track II diplomacy. Additionally, within the framework of existing church-state relations in some states, religious and faith-based non-state actors have become, to a certain extent, representatives of track I diplomacy (Stensvold and Vik 2018). As Raffaele Marchetti rightly stresses, it is thus important not only to realize the increasing influence of the civil society actors on the country's foreign policy, but to also realize how foreign policy is increasingly made in the first person by the civil society actors themselves (Marchetti 2018).

The significance of religious contribution in the normative sense, but also through creating a specific set of proposals to the most challenging problems of the present era, has been well evidenced in the case of migration issues. When analyzing prospects of dealing with the problem of migration a decade ago, it was possible to state that the liberal state may choose to develop a systematic approach to the problem of immigration, which means it can come up with a view of what kind of people it wants to include or exclude, but it may also choose not to develop such an approach (Risse 2008). 
The second option no longer seems possible, which proves the dynamism of the situation as well the necessity of quick, innovative reaction. In the face of the increasing challenge of migration, some very harsh responses to the problem were applied in countries like the USA or Australia, as well as in some countries of the CEE region. The migrants were either rejected the possibility of entering the country under any conditions or they were, as in the case of the USA and Australia, directed to detention centers that provided heavily criticized standards of treatment. Finally, during Donald Trump's presidency, the procedure of separating the illegal immigrants from their children at the Mexican-American border was performed based on the "zero tolerance" policy (Foulkes 2012; Mittelstadt 2018). Meanwhile, the innovative measures rooted in the civil society initiatives have been introduced, constituting a valuable alternative in terms of ethical and political reaction to the drama of migration. As the examples of Australia and Italy show, religious communities and faith-based actors have always been actively involved in these responses. Using the concepts and practices consistent with faith-based hospitality they were able to challenge public discourse and to propose measures reflecting a wide, human-oriented perspective (Wilson 2011; Bernardo 2019).

In Italy, the project of Humanitarian Corridors introduced in 2015 by the group of civil society actors in agreement with the Italian government resulted in creating new channels of engagement and effective support for the most vulnerable ones within the existing legal framework. The solutions based on mobilization of the society and creating a big solidarity net have been recognized and appreciated at the governmental, European, and global level as the legal and safe resettlement of the asylum seekers. Although what religious and faith-based bodies have proposed and achieved in this regard cannot be perceived as an "all-encompassing" solution, they did effectively utilize their intellectual and material resources to creatively emphasize the ethical obligations of the government and the society (Rolando 2018).

The article is divided into three sections. The first one is focused on the theoretical analysis of the religious-political nexus and, more specifically, the concept of "religious engagement", which while referring to the area of foreign policy is also more or less directly affecting the domestic political developments in which religious and faith-based actors are engaged. In the second section, the religious and faith-based actors' role is discussed within the wider framework of the civil society sector regarding the evolution of mutual relations between the civil society sector and government. In this part, the issue of the specific placement and understanding of the concept of peace by the religious and faith-based actors is also considered. The third section deals with the problem of dialectics of migration perceived in the context of "duty dilemma" (Delsol 2016) between the political-cultural duty of the government to protect its population, territory, and cultural identity, and ethical duty to provide support to those whose lives are endangered.

In this paper, I propose looking at religious engagement through the prism of two major approaches developed in the religious context, especially Christianity, serving as the basic aim but also the instrument of constructing and reconstructing of the socio-political order, namely the relational and transformative approach. As the ordering remark, it needs to be emphasized that the project of Humanitarian Corridors discussed in the article has been selected due to its growing international visibility and effectiveness, as just one among numerous initiatives directed at supporting migrants undertaken by multiple faith-based actors.

\section{From "Missing Dimension" to "Religious Engagement": Reconceptualization of the Relations between Religion and Politics}

When looking from the historical perspective at the development of the new, post-Cold War understanding of mutual relations between religion and politics, the current moment may be regarded as an important point of reflection. A quarter of a century ago, in his milestone publication, former US diplomat and political scientist Douglas Johnston was calling for the change of the paradigm between religion and politics. According to his view, which turned out to be enormously influential for further developments: "The application of religious factors to political problems is inherently 
complex and fraught with peril; hence the Western predilection for maintaining a complete separation between the two. But the potential for overcoming the shortcomings of conventional diplomacy in some situations by introducing religious or spiritual factors appears to be substantial. It suggests that foreign policy professionals and religious practitioners should study the possibilities and seek to facilitate and reinforce one another's efforts to resolve conflict wherever it appears sensible to do so" (Johnston and Sampson 1994). In the book, referred to widely in the literature on the topic, Douglas Johnston thus focused not only on "bringing religion back", but also on building the area of common support, and even cooperation in the field of conflict resolution where religious factors simply cannot be overlooked. At the same time though he was calling for the profound change in the area of both domestic and foreign policy towards including the more holistic, more relational, and in fact more anthropocentric perspective taking into account also the non-state actors. "The challenge is to reach beyond the state-centric focus on power-politics model to accommodate non-governmental interactions at the subnational and individual level" (Johnston and Sampson 1994).

Since then, the long distance has been covered in terms of the empirically visible emergence of the religious factor in the area of global politics, in respect to gaining knowledge and understanding of this emergence, and finally in evolving a normative outlook on the role of religious resources in the public discourse. The significance of the topic, as well as its complexity, has been increasingly expressed through the growing epistemic community of activists, scholars, and policymakers recognizing that the religious factor can no longer be ignored (Bettiza 2019).

For both the policymakers and scholars, the crucial obstacle and challenge is the "form" of secularism that has dominated in the public space and in social science. The essence of this particular approach, which became decisive in the discourse, was the positioning of religion as the "enemy", and preventing any other type of more "friendly" outlook. Secularism in this pervasive version is not a neutral, objective theory trying to explain the direction of development of the reality, but its ideological, dogmatic, exclusivist vision that led to "secular bias". What has been analyzed and explained over the last decades is that the challenge of overcoming "old thinking" is even deeper when considering the "Westphalian synthesis" and influential Westphalian-Enlightenment prejudice, which introduced the mythologized, reductivist perspective of religion in the process of the development of the modern state system (Philpott 2000). As a consequence "blind spots" (Petito 2019) occurred, which can be summarized as not just "overseeing" the huge and meaningful dimension of objective reality, but forming the discourse based on the purposefully constructed vision of this reality based on "fairytales" (Thomas 2005), "legends" (Barnett 2015), and "myths" (Cavanaugh 2009).

As a reaction to this "ontological injustice" (Wilson 2017) first in the US and the UK, and later in continental Europe, considerable reconceptualization of the dominating secular perspective has been postulated. Soon, around the beginning of the new millennium, the breakthrough concept, the ambivalent role of religion in the socio-political reality has been proposed (Appleby 2000; Gopin 2000) and the field of the religious peacebuilding has emerged, first in the US and later in Europe (Hertog 2010). Almost at the same time, the notion of post-secularism has been developed (Habermas 2001), which contributed significantly to the redefinition of mutual relations between religion and politics. Finally, the far-reaching concept of religious engagement has been suggested (Appleby et al. 2010) and developed gradually, not only as a theoretical construct, but also as the element of the new institutionalized approach to religion (Petito and Thomas 2015; Mandaville and Silvestri 2015; Bettiza 2019; Petito 2019).

Out of many different empirical and theoretical consequences of "bringing religion back" and including it as a valuable partner in the search for the "common humanity", the "3D" perception could be proposed as the one summarizing the reconceptualization in terms of placement of the religious factor. They would be demythologization, dualism, and dialogue, simultaneously creating, as it seems, a coherent vision of the discussed reconceptualization. Demythologization would refer to both secularism and religious violence perceived so far as the main "option" for religious presence in the public sphere. Dualism would concern on the one hand "reaching beyond" and overcoming of the perception of religious and secular as separate spheres, but also understanding the dichotomic, 
ambivalent role of religion. It would lead to a new sensitivity about reality perceived so far as the neatly separated, closed domains of the meaning of "secular, rational and public" and "religious, irrational and private" (Wilson 2012). Through the overcoming of this exclusivist approach, the space for an inclusive, dialogical view could be constructed. Dialogue would mean in this regard creating the possibility of encountering both, so far separated spheres of the sacrum and the profanum.

Though the concept has been questioned and contested (Mavelli and Petito 2014), post-secularism did enable a new stage of discussion and facilitated a "new reading of reality". As Luca Mavelli and Fabio Petito notice: "The question raised by the post-secular ( . . ) is not just one of incorporation of the presence of religion or the power of secularism into existing theoretical frameworks, but one of the conceptual innovations to account for a transformation that invests the very structures of consciousness and power, and existing understandings of political community" (Mavelli and Petito 2014). When the post-secular perspective is recognized and included in the discourse on the evolution of contemporary world order, it allows for the assessment of the contemporary socio-political sphere as neither secular, nor linear, but transformative.

As a result of the "post-secular turn", post-secular consciousness and post-secular sensitivity have been created, which to a significant extent express themselves in the concept of religious engagement. This new perspective not only allows religion to be more present in the public sphere, but also sees religion and religious actors as the valuable resource in all the domains of socio-political reality as "religion's importance and relevance is more wide ranging than is indicated by limiting its presumed role to the impact of ideas on politics" (Petito and Thomas 2015). The crucial aspect here is the concept offered by Jürgen Habermas of approaching religion as the depositary of "normative intuition" and thus as the potential source of the "change" that occupies central place in the major religious doctrines (Gopin 2015; Gawerc 2006).

Religious engagement embodies all the crucial elements of this new perception of secular-religious nexus first championed by the constellation of civil society actors embedded in and responding to an emerging post-secular world society. The beginning of the process can be dated back to the early 1990s, with acceleration in the aftermath of 9/11. At that time, the loosely knit epistemic community emerged among international affairs scholars and analysts in the US. This epistemic community, which became the carrier of post-secular consciousness, has developed two strategies of religious engagement. The first one, a narrower one and referring directly to the intellectual and practical contribution of Douglas Johnston, sees religion as the means of promoting world peace and security. The other one is more ambitious and more broadly recognizes religious contribution in terms of promoting international order and progress (Bettiza 2019).

The concept of religious engagement does not refer to the simple developing of good relations with religious and FBOs actors. The concept is to draw attention to the new ways in which governments can engage and partner with religious and faith-based non-state actors to deal with a wide spectrum of global policy issues and challenges. Crucial for the religious engagement is also understanding its prophetic potential. In this understanding, religious engagement is perceived through its ability to develop the new secular-religious partnership, stretching the political imagination and creating practical innovations to respond to global policy challenges (Petito 2019).

The perspective of religious engagement, understood as a religious-secular partnership, brings the profound reconceptualization of how the Western, and more specifically Eurocentric civilization, has been oriented in terms of the limited lens of perceiving and understanding of the social-political constellation of today. The deliberations on understanding of such crucial concepts as progress or inclusion of the other (Buber 1992, 1993; Lévinas 1994; Tischner 1998) have been the ever-present issue in the human reflection. What is currently happening in this regard should be perceived as one of the important dimensions of the transformation of the normative structure of international society, beyond its Eurocentric civilizational origin as well as liberal ideological configuration (Petito 2019). With the less self-centered, more pluralist, more inclusive, and more dialogue-oriented perspective, more options are "on the table" in the increasingly challenging socio-political post-secular reality. 
In the post-secular discourse, the wide definition of politics is referred to. This definition encompasses state-based politics and policies, but also dominant ideological visions that shape those policies and influence the narratives of the broader civil society and public sphere. Such a perspective brings recognition of the non-state religious actors as those who affect the understanding of power through contesting its source and meaning, but at the same time contribute to perceiving it through the prism of relationships (May et al. 2014). In this context, politics is about relationships, and active citizens are the ones who increasingly contribute to broadening of comprehension of how politics should be understood and how it should be performed (Saunders 2005).

\section{FBOs: Bridging Religious Engagement and Religious Peacebuilding}

The perspectives that post-secularism and religious engagement offer are multifold and multidirectional. They enable bridging, for the two-sided benefit, the non-religious and religious spheres as the ones mutually supporting, purifying, and improving one another (Ratzinger and Habermas 2006). The argument is raised in this regard on the irreplaceable role of religion in the public sphere, where religious actors are often capable of discovering hidden institutions or recreating lost elements of meaning and identity. According to the post-secular outlook, they profitably use modes of reasoning different from the public reason (Kratochvil 2009). On the other hand, from the side of the religious perspective, the argument is raised that the reason can only function well when it is enlightened by the light of faith (Mazurkiewicz 2012).

As political scientist Jeffrey Haynes rightly notes, one of the most visible signs of post-secularism has been the increasing presence of non-state religious actors at the level of civil society, both within and between the states. The decisive explanatory factor was the demise of optimism about the perceived "superiority" of rational secular values and the "( .. ) growing willingness to accept that maybe, after all, "religion" might have something to tell us about how to run international relations better, that is ideas and values stemming from religious beliefs might conceivably assist in states' developing cooperation and undermining chances of conflict, while helping to provide an ethical framework for improved international collaboration" (Haynes 2014).

The mutual relations between religion and civil society have been profoundly analyzed and well known in the literature of the subject (Casanova 2005; Berger 2003; Wilson 2014; Herbert 2003). As fundamentally belonging to the civil society sector, religions have increasingly been present in the public sphere joining the voices of contestation against the state and the market economy (Casanova 2005). In activating civil structures, religions play a few fundamental functions. Firstly, they mobilize modern societies to the collective and public reflection on the normative issues, and introduce their own arguments on the controversial problems. Secondly, they stress the principle of the common good and the community of the moral issues constituting the challenge against the individualist-liberal theories, which reduce the common good to the sum of the personal preferences. Finally, religions address the principle of solidarity with all the people emphasizing the superiority of the dignity of a human person over the dominating systems of the state power and capitalist market (Szymczak 2015).

Both the discourses and the practices of global political and economic liberalism not only enable but even necessitate FBOs' growth and spreading of scope of their activities, especially after the end of the Cold War and in conjunction with the retreat of the state (Lynch 2011). They contribute to building social cohesion, social capital, both bridging and bonding one (Putnam 2001) and "salvation" of civil society as such (Bretherton 2010). As the actors of the civil society belong neither to the state nor to the market, religious and faith-based actors may be seen as mediating structures and the expression of the people's empowerment (Berger and Neuhaus 1996). In this role, they are part of the process through which the individuals negotiate, argue, struggle against, and agree with each other and with the centers of political and economic authority (Kaldor 2003).

Religion is both much more and much less than meets the eye (Barnett 2015). Religious and faith-based actors play not only a corrective (Mazurkiewicz 2012), but also an innovative role. In the process of the discussed reconceptualization of the relation between the secular and the political, 
religious and faith-based bodies have not only emerged as the "first-aid" providers, but also as the source of alternative proposals towards how the complex challenges in the domestic and international scale should be approached. As such, they have been actively engaged in political campaigning and advocacy work, and in promoting an alternative political and ethical paradigm based on which policies can be developed and implemented (Wilson 2014). In the face of retreat of the state and the need for alternative proposals regarding numerous new problems that are unveiled in the socio-political reality, religious considerations are often arising as not one of many, but the main or the only resource to refer to. As a result, their contributions are becoming increasingly visible and recognized as the element of developing "ethical imagination" and "ethical capacity" at the civil society level, both locally and globally. At the same time, though oriented towards the transcendence, the focus of faith-based actors is very much anthropocentric and oriented towards introducing the change in the social-political dimension, and is thus transformative.

FBOs function in a multi-dimensional manner in terms of engaging society. On the one hand, they are directed at the outside environment, meaning those in any kind of need for material and non-material support. Acting as such, they influence the political sphere both as the service providers and as the "idea providers". On the other hand, they are directed at their "internal environment", which means expressing certain values and attitudes based on their moral orientations and commitments. In fact, in the case of transnational FBOs, the differentiation into the "internal" and "external" environment is difficult to define. As such, they become "cosmopolitan" and gain the possibility of transferring the local innovations to the national and global level. What needs to be stressed in this regard is their flexibility and, in a majority of cases, the capacity of adjusting to the socio-political reality. Theologies constantly evolve to cope with the changing political conditions, liberalizing economies and the links between individual and communal rights and practices (Lynch 2011).

Both a narrow and broad understanding of the concept of religious engagement are more or less linked to the issue of peace being the most fundamental, yet the most unrealized human need (Ramsbotham et al. 2011). Peace is the major goal and commitment of all the major religious doctrines, as well as underlying purpose of the political communities (Cortright 2008). Holistically, anthropologically understood peace should be thus perceived as the most fundamental framework for religious-political partnership. What needs be focused on as the area of overlapping and mutual inspiration is the notion of positive, just peace and not the negative peace, meaning the absence of conflict. Present in the religious doctrines since ancient times, with the Book of Isaiah being its most well-known example, the broadly understood concept of positive, just peace has been transferred into the secular domain. Peace has thus been increasingly recognized in the relational and transformative dimension (Galtung 2007; Lederach 1999).

The "father" of Peace (and Conflict) Studies Johan Galtung notices that the good start for discussion on the relations between religion and peace could be the word "religion" itself. As re-ligio can be interpreted as the relinking in the language of social science, this would mean some kind of integration (Galtung 2016). In the search for a dialogical approach to the problems of war and peace, religions could become the "joint human property" in the rapidly globalizing world (Galtung and MacQueen 2008). With their comprehension of conflict, religions may be perceived as the "ingenious" source of knowledge on how to solve it and as the "reservoirs of wisdom" (Gopin 2015).

The area of the "religious-political nexus" as the general framework for partnership embraces "thinking about peace" and "making peace", but also concepts such as "positive peace" and "just peace", as well as crucial from both the religious and secular perspective "transformation of the conflict" aiming at reconciliation. The innovative peace-oriented, relational, and transformative approaches engaging religious actors have been conceptualized with terms such as "relational diplomacy", "diplomacy of friendship", "faith-based diplomacy", and finally as the concept encompassing all the particular ones, namely religious peacebuilding (Hertog 2010).

Characterized by a high level of interdisciplinarity, religious peacebuilding is defined as the range of activities performed by religious actors and institutions for the purpose of resolving and 
transforming conflicts with the goal of building social relations and political institutions, characterized by an ethos of tolerance and nonviolence (Little and Appleby 2004). Being the crucial though rarely discussed and analyzed dimension of the "return of religion", religious peacebuilding implies reaching to the peaceful sources of the different religions in the doctrinal and ethical sense, which translates into multilevel activities undertaken by the religious and faith-based actors. At the same time, referring to the ever-existing links between religion and politics, religious peacebuilding can be perceived as the increasingly institutionalized dimension of the mutual interactions between sacrum and profanum (May et al. 2014).

Both in the theoretical and in the empirical sphere, religious peacebuilding has gained the status of the bridge between activities undertaken by religious and non-religious actors in the area of conflict resolution and peacebuilding. The meaningful symptom of this phenomenon has been the occurrence in the political and politological discourse of religiously rooted, "non-political" concepts such as reconciliation, guilt, or forgiveness. Along with them, such crucial notions as "positive peace" and "just peace", and also "brotherhood", "friendship", "love", and "hope" are more extensively discussed as the elements of an alternative approach to conflict resolution and peacebuilding, but also to politics as such (Kulska 2019).

As peace is a relation between parties, building peace means improving relations. In the relational approach the security concept will not be helpful. Since according to this view, some party is perceived as a threat to be deterred or eliminated, there is no focus on improving relations. To achieve peace, the transformation of relations is needed, which requires the transcending of goals of the parties and creating a new reality based on empathy, non-violence, and creative thinking (Galtung 1996, 2007). The desired outcome of this transformation is reconciliation (Lederach 1999). In this process, "the other" is de-demonized and rehumanized.

\section{Dialectics of Migration as a Political and Ethical Problem}

As peace is the value in the international reality, it is an ethical problem (Kuźniar 1991). The spreading of peace is the moral imperative at the level of individuals, institutions, and states regardless of their geopolitical location. At the same time, "ethics is born when "the other" enters the scene" (Eco and Martini 2019). "The other" means thus "the obligation" for those referring to some kind of transcendence and those not having such a point of reference. This is also the moment when politics comes in with its defining of "the other" for its own purposes and using its own political measures. While referring to distinct kinds of reasoning, the religious and non-religious overlap with reference to the fundamental human dignity (Solarz 2012).

The other is created to define the "borders". The defining ones are the governments and the societies. The process is dependent on numerous political, cultural, social, and economic determinants. But the final outcomes in this process of defining who "the other" is and what political measures to use while deciding on "the other's" image and political-cultural responsibility, can be influenced by non-political arguments and attitudes. This matters especially when realist, state-interest, and conflict-oriented political views are involved. States are the ones that do not always have the will or capacity to spread the message of peace (Egeland 2013). However, they do have to define themselves in terms of the relation towards "the other".

Dialectical relations towards "the other" can be detected when the etymology of both the term "guest" and "hospitality" is analyzed. In ancient times, on the one hand, the word guest meant someone who would be welcome and awaited and whose coming implied certain obligations on the side of the state. On the other hand the term was referred as "the other", or the enemy. This resulted in stretching the term between acceptance and affections and hatred or open enmity. From the very beginning, the term also resulted in some social and political consequences as "hospitality" was linked to unselfish care of the guest and at the same time deeply rooted in the ruler-serf dependence (Pisarek 2010).

From both the theoretical and practical point of view, migration has always been a dialectical phenomenon. This dialectic has unveiled itself both in the social-cultural and political dimension. 
For ages, migrations have been characterized by two co-existing phenomena. Although they meant the development and the enrichment of both the hosts and the hosted ones, they raised the issue of troublesome identity, exclusion, and fear. "The other" has thus been the instrument utilized by the those holding power to exercise their power in accordance to the immortal divide et impera and evoking the sense of fear, but also constituted the premise for mobilization at the social level to reach out to those marginalized ones (Kulska 2018).

What has grown to the extent of an enormous political challenge over the last decades has been the clash between ethics and politics with reference to "duty dilemma" in the context of migration issues, and especially the problem of refugees. The political and cultural obligation of the government is to protect the population not only in the sense of territory, but also safeguard the culture which the given population recognizes as its fatherland. In this regard, the government is authorized not to allow the refugees to enter, even if this violates the moral obligation towards those in need. When looking from the moral perspective, the view is different as the society has the moral obligation towards those who are in need, even if this would undermine the cultural identity of the hosting country (Delsol 2016). Simultaneously, the most subtle dilemma in politics occurs specifically within the dilemma of choosing of the lesser evil (Grosfeld 2010).

The migration issue invokes the eternal question of the relations between politics and morality on a universal scale. Assessment of debates upon the political limits of migration is essential to understand the evolving conditions and determinants of the contemporary politics. Out of many social-political challenges that governments have to face, migration appears to be one of the most complex and most challenging ones. The problem of migration could be perceived as the lens through which all the major dilemmas of the relation between the individual, the society, and the state focus. Refugees reveal a deep contradiction in contemporary patterns of political sovereignty. The issues of migration and asylum bring to the fore the question about relations between identity, citizenship, and the rule of law (Bretherton 2010). Among them, there is the inclusion-exclusion issue, and in this context, there is not only the "politics of identity" problem, but also the "politics of fear" problem (Fukuyama 2019). The crucial challenge, not just legal but also moral, is assessing illegal immigration and asking ourselves as citizens, but also as humans, are the illegal migrants actually doing something wrong? There is no doubt they are breaking the law but arguably, from a moral standpoint, not all methods of breaking the law are to be condemned (Risse 2008).

When describing the struggle between duty and morality, Darwin stresses that the instinct of sympathy or empathy constitutes the most noble part of human nature and that the highest moral achievement is concern for the welfare of all living beings, both human and nonhuman (Ekman 2010). This statement, though not referring directly to the sphere of politics, carries an enormous political weight. You cannot create a good citizen unless one is a good person (Mazurkiewicz 2007). Though defining the term of a good man is not an easy task, one might, following Darwin, risk the statement that definitely empathy is important component of the man referred to as "good". The crucial issue is how to foster this instinct of empathy in the society. The question belongs to the category of the fundamental ones, not just in relation to the problem of "defining the borders". The matter seems to be of pivotal importance also in the perspective of social cohesion and social capital and the conditions of functioning in the society deprived of empathy towards any, both internal and external, "the other" (Nussbaum 2015).

Religion is the most, or at least one of the most, effective cultural practices defining the individuals and the communities. It helps to determine, implement, and authorize what is good, what is evil, what is right, and what is wrong (Petito and Thomas 2015). At the same time, religions, particularly those with formal institutional structures, are one of the few means of mobilizing people for common, public action. As such, they provide an opportunity to move beyond politics perceived through the prism of legal and market proceduralism but, what's even more challenging "they keep alive ultimate questions about what it means to be human and what a good life consists of in such a way as to re-open the need for political deliberation about what we value and why we value it" (Bretherton 2010). 
In the conditions of the deliberative democracy, the state does not have a monopoly in defining the social and cultural borders of "moral imagination" and "ethical capacity". What is essential in this regard is the engagement of the civil society and its role in shaping the image of the other and the attitudes towards "the other". The religious voice can be regarded as important and useful for achieving "social sensitivity" resulting from "bringing up" the society and developing the awareness and compassion towards those more vulnerable. The specific dimension of "knowledge creation", but also "relationship creation" in the conditions of the post-secular society can be recognized as the pivotal responsibility on the side of the religious and faith-based actors.

Encounter, dialogue, and knowledge are the elements of religious engagement, and all embrace different dimensions of inclusion and recognition of the value of religious contribution. Following cognitive and communicative aspects of partnership between religion and politics, relational and transformative aspects occur. These aspects, both in the conceptual and operational sense, are embodied at two main levels. The first of them is the level of civil society, where the non-state religious and faith-based bodies address their activities at the subjects, both individual and collective ones, directly with no involvement of the state. But there is also the second possibility of addressing their activities as the actors of the civil society sector with the involvement of the governmental level. While an increase in the level of "overlapping" of the religious and secular activities increasingly raises the questions of the "healthy limits" of such a cooperation at the same time it offers new horizons of potential innovations to which the religious actors can contribute. As an element of the public discourse, this could also refer to the dialogue between the state and the active, participating citizens whose contribution may mean "added value" to the governments' activities (Saunders 2005).

The relationship between the governments and the civil society organizations (CSOs) should not be conceived as being unidirectional, where either CSOs influence the state or the state co-opts the CSOs being predominant. "The relationship is rather of mutual synergy effectively improving the political capacity of both actors". In the process of practical accomplishment of the project, both sides can benefit from each other's "channels of access" that both sides possess. While CSOs need to rely on government actors to access diplomatic negotiation channels, governments can benefit from the indirect support offered by the CSOs. Among the most important dimensions of such support, apart from offering technical skills and infrastructural resources, generating awareness and public support in the countries to be persuaded are of crucial importance (Marchetti 2018).

Migration, both as a political and an ethical problem, has always been a part of human history and a topic of both secular and religious reflection. At the present moment, migration is one of the key reasons for the emerging of post-secular society. According to the new post-secular perspective, religious communities need to be perceived as the "communities of interpretation" irrespective of whether religion occurs in their case as the stabilizing or destabilizing factor. On the other hand, the "post-secular consciousness" is created, which provides the opportunity to see "the other" from two perspectives. The "other" is the one who should be recognized and included as the subject that has the right to preserve identity and the mode of life (Kratochvil 2009). At the same time though, "the other" is the one that has something to offer the hosting community. The potential of offering some assets lies also on the side of the religious communities occurring in the role of providers of specific, more spiritual, but also practically oriented on the "the other" views and attitudes. They find their expression in the ethics of hospitality, which finds its roots both in the secular and religious reflection (Baker 2011; Wilson 2011).

\section{Humanitarian Corridors: From Fear to Empathy}

For the Christian organizations, the central concepts are charity, philanthropy, volunteering, and the notion of civil society (Bernardo 2019). They offer a very concrete, doctrinally embedded vision of how the problem of migration should be perceived. Faith-based hospitality is rooted in the theological arguments concerning the dignity and sacredness of every human being and commitment to follow the example of Christ (Wilson 2011), whose teachings introduced the revolutionary change in the 
perception of the relationship towards "the other", transcending the "rule of law" towards the "rule of love". As Leszek Kołakowski points out, Jesus' teachings were the challenge to the world from which the new universe has emerged. The essence of transformation that he proposed was love. The key issue, though, was that this transformation was not imposed from the position of the one holding power. His message was based on the force that changes the soul and makes it ready to follow the certain path (Kołakowski 2014). Love and compassion hold the center and require a fullness of commitment (Lederach 2014).

As such, Christ's calling "I was a stranger and you took me in" (Mt, 25, 35) is moral encouragement for the voluntary "reaction of heart", but also the call for responsibility for a transforming of the world that became the pattern for activities addressed towards those displaced ones. Yet in the Christian approach, not only the teachings but also the story of Jesus himself is the fundamental point of reference emphasized by the fact the entirety of Jesus's personal experience is one of a refugee (Montville 2016). "Jesus lived in a war zone under foreign military occupation in a period of civil war and violent insurgency against the foreign occupier and the domestic leaders who cooperated with the occupying forces. He and his family were refugees, according to the definition of the 1951 Convention on Refugees; they fled genocide, as described in the 1948 Convention for the Prevention and Punishment of the Crime of Genocide" (Cusimano Love 2015).

In the documents of numerous European Christian Churches referring to the migration issue "God is a God on the move whom we can meet in the stranger". They underline the necessity of building the "culture of welcome" and the "culture of encounter" in the spirit of solidarity and universal community based on human fraternity in spite of all the difficulties that opening to others entails. Christian cosmopolitanism can be perceived as an alternative to overly-protectionist visions of the nation-state in addition to the abstract accounts of liberal cosmopolitanism that calls for borderless states (Bretherton 2010). At the same time, the religiously rooted concept of just peace critiques, complements, and supplements the liberal peace (Omer 2015). Contrary to reducing the hospitality only to charity (Baker 2011), just peace criteria include a participatory process, the right relationships, restoration, reconciliation, and sustainability (Cusimano Love 2015). In the area of migration, just peace means, first of all, the relational and transformative dimension aimed at building the new reality both for the hosted ones and the hosts.

The establishment of "deep, serious and intense bonds between those who organize the project and the beneficiaries" (Rolando 2018) has been one the priorities of Humanitarian Corridors. The project has served as the ground-breaking solution proposed by a group of Christian actors to deal with the migration problem after its drastic increase in 2015. The concept of Humanitarian Corridors, which became the exemplification of religious engagement first in the relation with the Italian government, and later some other European countries, constituted not only some legal option directed at those putting their lives at risk while trying to cross the Mediterranean Sea. It also showed the small-scale, yet epochal alternative, towards the governments and the societies struggling to respond to this axiological and normative challenge to solve the "duty dilemma". As such, Humanitarian Corridors became both ethically and politically acceptable ways to reconcile between the political-cultural demand to protect the population and moral obligation to reach out to "the other".

Three crucial actors were engaged in the introduction and realization of the project: The Waldensian Church, the Federation of Protestant Church, and the Catholic Community of Sant'Egidio. The concept and procedures consisted of a few stages. The main role for the start of the project was played by Waldensian Church, which made available the capital for the initial phase of the project based on the "eight per thousand", which means $0.8 \%$ of the annual tax received from the state of Italy. Later, the original sponsors were joined by others, including private individuals, societies, cooperatives, labor unions, and other religious communities that consisted of particularly Jewish and Asian communities (Rolando 2018). What was created was a big solidarity net and a peculiar form of "ecumenism in action" (Bernardo 2019). 
The legal mechanism of the project is based on Article 25 of the Schengen regulations, which allows a state to release humanitarian visas in order to allow the vulnerable people to be exceptionally granted access to the country. After the mechanism was developed conceptually, it was proposed to the Italian Ministry of Foreign and International Affairs. As a result, the memorandum of understanding was signed in December 2015 and renewed in November 2017. It envisaged bringing into Italy up to 1000 asylum seekers per cycle in a safe and legal fashion.

Three main objectives were aimed for in the project. Firstly, it was making the arrival to Italy safe and legal. Secondly, it helped the refugees to overcome trauma that all of them experienced in a majority of forms. At this stage, it was also important to make them understand how they might imagine their new lives in Italy. Thirdly, it helped them to find a job and eventually to become independent. In the process, two standards were applied, which were avoiding the concentration of the newcomers in one location and engaging the local communities to take part in the reception. Those accompanying the refugees are thus not professional social workers, but usually volunteers concentrated around the church or the parish (Rolando 2018).

One of the actors that has participated within the project and soon has become the "face" of the initiative is Community of Sant'Egidio. In this way it followed its 50-year-long tradition of developing the unique model of lay vocation (Johnston 2008). Through its original interpretation of the Christian message, an innovative and effective community constitutes one of the most compelling examples of transcending existing visions and practices in the area of religious engagement. Established in 1968 by a group of high school students under the leadership of Andrea Riccardi with the purpose to practically perform the premises of the Second Vatican Council, it refers to five pillars: Prayer, evangelization, solidarity with the poor, ecumenism, and dialogue (Community of Sant'Egidio 2020).

The essence of Community's goals is expressed in the $3 \mathrm{P}$ concept, meaning prayer, poor, and peace. Following this framework, Community has become one of the most well-known bodies advocating for the poor and marginalized ones, but also the successful mediator and facilitator in the area of religious peacemaking. As such, Community has been engaged in numerous global campaigns dealing with AIDS or the death-penalty, and also in coordinating the World Day of Prayer for Peace in Assisi, initiated by John Paul II in 1986, which brings yearly representatives of numerous different religions. Even though the members carry out their work of service on a strictly volunteer basis, and they use virtually no paid staff, Community has been able to make a substantial difference in the places where it operates. On the local scale, this means running soup kitchens and small group homes for the elderly and AIDS patients, and providing numerous services to immigrants and refugees. On the larger scale, it means advocacy on a number of issues such as the rights of the elderly and immigrants or the global campaign against the death penalty (Johnston 2008).

Community has been well-known for successfully brokering the peace negotiations that led to ending the bloody war in Mozambique (Albright 2007) as well as in numerous other conflicts over the last decades. In fact though these activities have been perceived through the lens of service to the poor. Andrea Riccardi emphasizes that Community's orientation towards faith and evangelical inspiration are at the heart of its existence, and its main and fundamental identity is "first and foremost a Christian community" (Riccardi 2013). Known as the "U.N. of Trastevere", Community of Sant'Egidio's self-understanding has relatively little to do with diplomatic work: "Rather, Sant'Edigio is primarily a community of lay people who try to live the gospel through a life of prayer and service to the poor" (Johnston 2008).

While encounter and dialogue are the main aspects of the concept of religious engagement, they are also the essence of the Sant'Egidio's theoretical and practical alignment. Encounter means to "encounter with real people" and dialogue "is ingrained in the DNA of the Community". Peace is achieved through dialogue, search for common good, mediation, and agreement, which are the determinants of developing human relationships (Riccardi 2013). Equally important is not just bearing "witness" to the moral or religious value of peace, but acting in practice to achieve it. Present only in the sphere of hopes and dreams, peace may be practically achieved when its vision is internalized. This 
capacity to dream in reality should be perceived as one of the main Community's sources of success. What it entails is transformation of perception of reality in such a way that the inability to envision the peaceful, undivided future is altered with the new hopeful alternative that reaches beyond the existing options (Riccardi 2013; Johnston 2008).

The constituting framework organizing Community's universal vision based on the hope for change is a vision of overcoming indifference and building a more human world where there will be a place for everyone (Pope Francis 2017). The core of the image of a peaceful, just world is fundamentally expressed in the vision of "the other". Being the central focus in the spirituality of Community's perception of the other has been significantly shaped by the theological influence of one of the most important theologians of the XX century and the participant of the Second Vatican Council French theologian Yves Congar. According to Congar, the key moral test for Christians who would be engaged in the world is their attitude towards "the other". In his perception, true dialogue, which is the foundation for the church's relations to the world, depends on the ability to accept "the other" as other, and the willingness to be open to what "the other" can teach us (Johnston 2008). Thus, the notion of dialogue is not the normative concept, but the base for the members of the Community to practically, on a daily basis, open themselves up to developing relations of friendship with those encountered ones. This particular concept of true opening to "the other", building the real, direct relations based on patient communication has become the unique instrument worked out the Community known as "diplomacy of friendship" (Giro 2000).

"To be holy is the world" has been the essence of Community's spirituality and practice (Johnston 2008). Based on the conviction that responsibility and ability to act rely upon ordinary people, the citizens, Community is orienting itself towards the demanding, innovative initiatives through which it creates its own, specific mode of "knowledge" utilized in numerous projects realized both in Italy and abroad. Deeply rooted in the spirit of the Second Vatican Council and the influence made by Ives Congar, it strongly refers to his vision of constructing the Church through new, different forms of fulfilling the Gospel without betraying its truth and its tradition, the forms of holiness less opposed to the earthly life. As such, it operates towards recognizing the reality beyond the existing constraints. This mode brings together some elements of visionary idealism but, at the same time, pragmatism based of the experience gained during the years of its multidimensional service to "the other" based on the premise that no people are strangers, especially not those experiencing suffering (Johnston 2008; Riccardi 2013).

Community has been engaged in helping migrants since the 1970s when they started to be a significant component of the Italian society. Since then, the two main objectives have been organizing practical support in receiving and integrating migrants. In 1982, Community organized the first language course for immigrants, perceiving the knowledge of Italian as the "access key" to integration. Soon, the branches of the School of Language and Culture were established in numerous Italian and European cities, creating this way the "high-impact generators of inclusion". At the end of 1980s, the movement called the People of Peace was established, which is supported by the Community as the place for creating the culture of "peaceful and sympathetic citizenship" among the people of different ethnic and religious origins.

Since 2015, over 2400 refugees were safely relocated in Italy with the support of local organizations, parishes, and the people of good will (Del Re 2019). Even though the scale of the Humanitarian Corridors project is not big, and definitely not sufficient compared to the scale of needs, it was a "small step to remove the brick from the wall" (Gois and Falchi 2017) that did create first the "domino effect" and later the "spill over effect". Following Italy, the agreements on establishing the Humanitarian Corridors were signed in the subsequent years with France, Belgium, and Germany (PAP 2019). Later, the pattern was transferred into the global discourse, becoming the "show case" in terms of new solutions for asylum seekers. As such, the project was discussed as one of the proposals for the Global Compact on Refugees, which was a non-binding international agreement that was adopted by more than 180 states in December 2018. The document, which was approved after two years of extensive consultations led 
by UNHCR with Member States, international organizations, refugees, civil society, the private sector, and experts, is to serve as a framework for more equitable responsibility-sharing. It not only recognizes that a sustainable solution to the problem cannot be achieved without international cooperation. In fact, it calls for the transformation of the image of refugees, showing their presence as an advantage to the communities that host them (United Nations 2018). In the statement at Global Refugee Forum one year later, Emanuela Del Re, Minister of International Cooperation for Italy, pointed out that "Italy has never lost the sense of its moral responsibility towards women and men in need" and that "Every person counts". She also stressed that Italy proposed the model of Humanitarian Corridors at the European Parliament as a pattern to become a European practice in the form of European Humanitarian Corridors (Del Re 2019). In 2019, Humanitarian Corridors, as the complementary pathway to existing third country resettlement programs, has been recognized by UNHCR as a "ground-breaking cross-border initiative". As such, UNHCR has named the project as regional winner of the prestigious Nansen Refugee Award (Patisson 2019). The agency praised the scheme as a "lifeline for those at greatest risk" and an urgently needed pathway for protection (Higgins 2019).

The Italian case of cooperation between the religious and faith-based actors can be perceived as an example of the intense effective synergy that has been established between the Italian government and the organizations of the Italian civil society. Looking from the perspective of gains on the side of the government, the long-time cooperation between civil society actors and the government has made it possible for Italy to take a leading role at the international level, moving from rule-taking to rule-making (Marchetti 2018).

The concept of Humanitarian Corridors constituted the visionary, engaged response to probably the most dramatic and most pressing humanitarian issues of the last decades. In this process, thanks to the religious perspective, the important innovation has been proposed. This innovation, based on knowledge coming from encounter and dialogue, served both as the purpose and as the instrument of relational and transformative approaches to problem of migration. The project of Humanitarian Corridors shows that religious contribution should be recognized at many different levels which, to a certain extent, serves as the role-model of what religious and faith-based organization can offer as the "added value". As a type of "bottom up" project, fully organized and financed by the civil society, it created the solidarity net that became the message to the politicians and to the societies raising their knowledge of "the other" and the sense of empathy which is the condition of proper functioning of the society. This way, the receiving societies and the governments become themselves the beneficiaries of the project, not only at the intercultural, cognitive, and communication level, but also through the prism of "emotional capacity" and "ethical imagination", contributing to development of civic participation, engagement, and responsibility (Safjan 2018).

\section{Conclusions}

Over the last three decades, many religiously rooted ideas and institutions have been effectively developed and applied as the result of a secular-religious partnership. While reaching the doctrinal and ethical fundaments, they often transcended the existing notions constituting the source for the further mutual inspiration. Among them, there are such fundamental concepts as reconciliation, just peace, relational diplomacy, or transformation of conflict. Along with other socio-political problems where the non-state religious and faith-based actors turned out to be indispensable, there has also been the issue of migration.

The religious and non-state actors have long been involved in providing humanitarian aid to the displaced person. However, in the face of the scale and nature of the migration wave that Europe has been struggling with since 2015, their engagement gained a new innovatory form and a new dimension. As such, the issue of migration has become one of the main areas where not just the "technical solutions" but the ethical dimension as well has to be recognized, thus constituting the vast area of creating "common knowledge" on contemporary political challenges. In this process, 
the "reinclusion" and "reappreciation" of the religious dimension turned out to be an indispensable option for political deliberations.

The project of Humanitarian Corridors can be perceived as the exemplification of the religious-political partnership in which policy is not only significantly influenced, but in fact made in the first person by civil society actors themselves. Since 2015, the project carried by the Waldensian Church, the Federation of Protestant Churches, and the Community of Sant'Egidio served as a successful innovation and a case of multi-stakeholder engagement not only to the most vulnerable refugees, who were offered legal and safe resettlement, but also the involved governments and the European societies struggling with the "duty dilemma" between the political and moral obligations towards "the other". As such, the project can be perceived as the pioneering case of civil society mobilization not against but with the government, as well as the instrument of creating of civic culture recognizing "the other" not as inferior, but as equally important and vulnerable. In this process, the religiously rooted perspective of re-humanization against dehumanization was applied, which is the essence of the relational and transformative approach in the area of religious conflict transformation and peacebuilding.

Ethics is born when "the other" enters the scene. While obviously acts of altruism are not reserved solely to those referring to some religious foundations, civil society initiatives expressed in the form of the Humanitarian Corridors can be perceived as the demanding call aimed at raising the ethical awareness and fundamental empathy on the side of society, as well as offering a legal and politically acceptable solution to the government. As a result, "multi-sided" advantageous political- religious partnership has been constructed. It expresses itself in the "concentric triad" of those "empowered" in the process, meaning the migrants, civil society actors, and the government.

Among the numerous advantages of the project, the essence of the "empowerment" could be reduced to fundamental significance of rudimentary moral considerations. In a way, the explanation for those activities at the motivational level can be recapitulated in the two main ideas referred to by the actors engaged in Humanitarian Corridors, both on the non-governmental side. "Every person counts" (Del Re 2019) and "A few small drops can change the sea" (Gois and Falchi 2017) could be well used as the evidence of the already achieved level of mutual understanding and stimulus between the religious and the political. The human being is not only homo politicus, but also homo religiosus and homo esperans. The sharpened perspective on this multidimensionality of the individual combining all those equally important aspects of "human condition" has been better understood, respected, and acknowledged.

Ethics, which according to Kant means the relation towards what is the absolute good, introduces dynamism in the social life (Mazurkiewicz 2007). Religious-secular partnership becomes the source of the dynamic progress at both the political and human level. Reinclusion, reinterpretation, and reappreciation of the religious voice creates a new "window of opportunity" (Mendieta and VanAntwerpen 2011), which can be constructively utilized for advancing the ever-present challenge of defining and constructing of "common good" and "common humanity".

Funding: This research received no external funding.

Conflicts of Interest: The author declares no conflict of interest.

\section{References}

Albright, Madeleine. 2007. The Mighty and the Almighty. Reflections on America, God, and World Affairs. New York: Harper Perennial.

Appleby, Scott R. 2000. The Ambivalence of the Sacred: Religion, Violence and Reconciliation. Lanham: Rowman \& Littlefield Publishers.

Appleby, Scott R., Richard Cizik, and Thomas Wright. 2010. Engaging Religious Communities Abroad: A New Imperative for U.S. Foreign Policy. Chicago: Chicago Council of Global Affairs.

Baker, Gideon. 2011. Politicizing Ethics in International Relations: Cosmopolitanism as Hospitality. New York: Routledge. 
Barnett, Michael. 2015. Religion and the Liberal International Order. In Faith, Freedom and Foreign Policy. Challenges for the Transatlantic Community. Edited by Michael Barnett, Clifford Bob, Nora Fisher Onar, Anne Jenichen, Michael Leigh and Lucian N. Leustean. Washington: Transatlantic Academy, pp. 8-29.

Berger, Peter L. 1999. The Desecularization of the World: A Global Overview. In The Desecularization of the World: Resurgent Religion and World Politics. Edited by Peter L. Berger. Washington: Ethics and Public Policy Center, pp. 1-18.

Berger, Julia. 2003. Religious Non-Governmental Organizations: An Explanatory Analysis. Voluntas: International Journal of Voluntary and Non-Profit Organizations 14: 15-39. [CrossRef]

Berger, Peter L., and Richard L. Neuhaus. 1996. To Empower People: From State to Civil Society. Washington: AEI Press.

Bernardo, Angela. 2019. Communicating Religion in the Age of Emergency. In Mediterraneo. Tradizione, Patrimonio, Prospettive. Una Proposta per L'innovazione e lo Sviluppo. Edited by Alberto Aghemo and Rosella Pace. Roma: Fondazione Giacomo Matteotti, pp. 255-73.

Bettiza, Gregorio. 2019. Finding Faith in Foreign Policy. Religion and American Diplomacy in a Postsecular World. New York: Oxford University Press.

Bretherton, Luke. 2010. Christianity and Contemporary Politics. The Conditions and Possibilities of Faithful Witness. Chichester: Blackwell Publishing. [CrossRef]

Buber, Martin. 1992. Ja i Ty. Wybór pism Filozoficznych. Warszawa: Instytut Wydawniczy Pax.

Buber, Martin. 1993. Problem Człowieka. Warszawa: Spacja.

Casanova, José. 2005. Religie Publiczne w Nowoczesnym Świecie. Kraków: Zakład Wydawniczy Nomos.

Cavanaugh, William T. 2009. The Myth of Religious Violence: Secular Ideology and the Roots of Modern Conflict. New York: Oxford University Press.

Community of Sant'Egidio. 2020. Available online: http://www.santegidio.org/pageID/2/langID/en/theCommunity.html (accessed on 29 March 2020).

Cortright, David. 2008. Peace: A History of Movements and Ideas. New York: Cambridge University Press.

Cusimano Love, Mayann. 2015. Building a Better Peace: A Future Worthy of Our Faith. Available online: https://www.americamagazine.org/issue/building-better-peace (accessed on 18 March 2020).

Del Re, Emanuela. 2019. Statement by Hon. Emanuela Der Re, Minister for International Cooperation If Italy at the Global Refugee Forum. December 17. Available online: https:/www.unhcr.org/en-au/events/conferences/ $5 \mathrm{df8f6fd4/statement-from-italy.html?query=humanitarian \% 20corridors} \mathrm{(accessed} \mathrm{on} 14$ March 2020).

Delsol, Chantal. 2016. Wielkie migracje a przyszłość Europy. Chrześcijaństwo-Świat-Polityka 20: 9-14. [CrossRef]

Eco, Umberto, and Carlo Maria Martini. 2019. Gdy na scenẹ wkracza inny, rodzi się etyka. Available online: https://www.przewodnik-katolicki.pl/Archiwum/2019/Przewodnik-Katolicki-38-2019/ Temat-numeru/Gdy-na-scene-wkracza-inny-rodzi-sie-etyka (accessed on 16 March 2020).

Egeland, Jan. 2013. Humanitarian diplomacy. In The Oxford Handbook of Modern Diplomacy. Edited by Andrew F. Cooper, Jorge Heine and Ramesh Thukur. New York: Oxford University Press.

Ekman, Paul. 2010. Darwin's compassionate view of human nature. JAMA 303: 557-58. [CrossRef] [PubMed]

Foulkes, Christopher D. 2012. Australia's Boat People: Asylum Challenges and Two Decades of Policy Experimentation. Available online: https://www.migrationpolicy.org/article/australias-boat-people-asylumchallenges-and-two-decades-policy-experimentation (accessed on 5 May 2020).

Fukuyama, Francis. 2019. Tożsamość. Wspótczesna polityka tożsamościowa i walka o uznanie. Poznań: Dom Wydawniczy Rebis.

Galtung, Johan. 1996. Peace by Peaceful Means: Peace and Conflict, Development and Civilization. Oslo: Peace Research Institute.

Galtung, Johan. 2007. Peace by Peaceful Conflict Transformation-The TRANSCENDENT Approach. In Handbook of Peace and Conflict Studies. Edited by Charles Webel and Johan Galtung. New York: Routledge, pp. 14-32.

Galtung, Johan. 2016. Religions Hard and Soft. In The Ashgate Research Companion to Religion and Conflict Resolution. Edited by Lee Marsden. New York: Routledge, pp. 247-63.

Galtung, Johan, and Graeme MacQueen. 2008. Globalizing God-Religion, Spirituality and Peace. Grenzlach-Whylen: Transcend University Press.

Gawerc, Michelle. 2006. Peace-building. Theoretical and Concrete Perspectives. Peace E Change 31: 435-64.

Giro, Mario. 2000. Sant'Egidio's diplomacy of friendship. The UNESCO Courier 53: 33-34. 
Gois, Pedro, and Giulia Falchi. 2017. The third way. Humanitarian corridors in Peacetime as a (local) civil society response to EU'S common failure. REMHU: Revista Interdisciplinar da Mobilidade Humana 51: 59-75. [CrossRef]

Gopin, Marc. 2000. Between Eden and Armageddon. The Future of World Religions, Violence and Peacemaking. New York: Oxford University Press.

Gopin, Marc. 2015. Negotiating Secular and Religious Contributions to Social Change and Peacebuilding. In The Oxford Handbook of Religion, Conflict and Peacebuilding. Edited by Atalia Omer, R. Scott Appleby and David Little. New York: Oxford University Press.

Grosfeld, Jan. 2010. Kilka uwag o losie chrześcijanina w polityce. Chrześcijaństwo-Świat-Polityka 11: 4-7.

Habermas, Jürgen. 2001. Glauben und Wissen. Frankfurt: Suhrkamp Verlag.

Habermas, Jürgen. 2005. Religion in the Public Sphere. Lecture Presented at the Holberg Prize Seminar. November 29. Available online: https://holbergprisen.no/sites/default/files/Habermas_religion_in_the_ public_sphere.pdf (accessed on 16 March 2020).

Haynes, Jeffrey. 2007. An Introduction to International Relations and Religion. London: Routledge.

Haynes, Jeffrey. 2014. Faith-Based Organizations at the European Union and United Nations: From Marginalization to Significance. In Towards a Postsecular International Politics: New Forms of Community, Identity and Power. Edited by Luca Mavelli and Fabio Petito. New York: Palgrave Macmillan.

Haynes, Jeffrey. 2016. Religious Transnational Actors and Soft Power. New York: Routledge.

Herbert, David. 2003. Religion and Civil Society: Rethinking Religion in the Contemporary World. New York: Routledge.

Hertog, Katrin. 2010. The Complex Reality of Religious Peacebuilding: Conceptual Contributions and Critical Analysis. Lanham: Lexington Books.

Higgins, Claire. 2019. Corridors of Hope: What One Italian "Life-Line" Delivers? Available online: https://www.kaldorcentre.unsw.edu.au/news/corridors-hope-what-one-italian- $\% \mathrm{E} 2 \% 80 \% 98$ lifeline $\%$ E2\%80\%99-delivers (accessed on 10 March 2020).

Jakelić, Slavica. 2015. Secular-Religious Encounters as Peacebuilding. In The Oxford Handbook of Religion, Conflict and Peacebuilding. Edited by Atalia Omer, R. Scott Appleby and David Little. New York: Oxford University Press.

Johnston, Douglas. 2003. Faith-Based Diplomacy. Trumping Realpolitik. New York: Oxford University Press.

Johnston, Laurie. 2008. "To be Holy in the World". The Influence of Yves Congar on the Spirituality and Practice of the Community of Sant'Egidio. In Catholic Identity and the Laity. Edited by Tim Muldoon. New York: Orbis Books.

Johnston, Douglas, and Cynthia Sampson. 1994. Religion, the Missing Dimension of Statecraft. New York: Oxford University Press.

Kaldor, Mary. 2003. The Idea of Global Civil Society. International Affairs 79: 583-93. [CrossRef]

Kołakowski, Leszek. 2014. Jezus Ośmieszony. Esej Apologetyczny i Sceptyczny. Kraków: Wydawnictwo Znak.

Kratochvil, Petr. 2009. The Religious-Political Nexus in East-Central Europe: Church in the Public Sphere of Post-Secular Societies. Perspectives 17: 119-38.

Kubálková, Vendulka. 2000. Towards an International Political Theology. Millenium: Journal of International Studies 29: 675-704. [CrossRef]

Kulska, Joanna. 2018. Faith-based Organizations and the migration issue. In Social, Cultural, Ethical and Political Aspects of Migration. Edited by Tomáš Hubalék, Gabriela Cingelová, David Hampl, Zoltán Huszár, Pavel Kopeček, Pavel Krákora, Joanna Kulska, Marcel Lincényi, Zsolt Nemeskéri, Zdenka Nováková and et al. Bammental: Bettina Weiss Verlag, pp. 57-75.

Kulska, Joanna. 2019. Między Sacrum i Profanum. Rola Czynnika Religijnego w Rozwiązywaniu Konfliktów i Budowaniu Pokoju. Opole: Wydawnictwo Uniwersytetu Opolskiego.

Kuźniar, Roman. 1991. Etyczne pojmowanie pokoju. In Pokój w Teorii i Praktyce Stosunków Międzynarodowych. Edited by Józef Kukułka. Warszawa: Wydawnictwa Uniwersytetu Warszawskiego.

Lederach, John Paul. 1999. Building Peace: Sustainable Reconciliation in Divided Societies. Washington: United States Institute of Peace.

Lederach, John Paul. 2014. Reconcile. Conflict Transformation for Ordinary Christians. Kitchener: Herald Press.

Lévinas, Emmanuel. 1994. O Bogu, który Nawiedza myśl. Kraków: Wydawnictwo Znak. 
Little, David, and R. Scott Appleby. 2004. A Moment of Opportunity? The Promise of Religious Peacebuilding in an Era of Religious and Ethnic Conflict. In Religions and Peacebuilding. Edited by Harold Coward and Gordon S. Smith. New York: State University of New York Press, pp. 1-26.

Lynch, Cecylia. 2011. Religious Humanitarianism and the Global Politics of Secularism. In Rethinking Secularism. Edited by Craig Calhoun, Mark Juergensmeyer and Jonathan VanAntwerpen. New York: Oxford University Press.

Mandaville, Peter, and Sarah Silvestri. 2015. Integrating Religious Engagement into Diplomacy: Challenges \& Opportunities. Issues in Governance Studies 67: 1-13.

Marchetti, Raffaele. 2018. Italian hybrid diplomacy. Contemporary Italian Politics 10: 193-207. [CrossRef]

Mavelli, Luca, and Fabio Petito. 2014. Towards a Postsecular International Politics. New Forms of Community, Identity, and Power. New York: Palgrave Macmillan.

May, Samantha, Erin K. Wilson, Claudia Baumart-Ochse, and Faiz Sheikh. 2014. The Religious as Political and the Political as Religious: Globalisation, Post-secularism and the Shifting Boundaries of the Sacred. Politics, Ideology and Religion 15: 331-46. [CrossRef]

Mazurkiewicz, Piotr. 2007. Polityka-eschatologia-etyka. Chrześcijaństwo-Świat-Polityka 3: 29-32.

Mazurkiewicz, Piotr. 2012. Niepolityczna polityczność Kościoła. Chrześcijaństwo-Śziat-Polityka 14: 5-20. [CrossRef]

Mendieta, Eduardo, and Jonathan VanAntwerpen. 2011. The Power of Religion in the Public Sphere. In The Power of Religion in the Public Sphere. Edited by Judith Butler, Jürgen Habermas, Charles Taylor and Cornel West. New York: Columbia University Press.

Mittelstadt, Michelle. 2018. Children on the Frontlines. Available online: https://www.migrationpolicy.org/article/ top-10-2018-issue-no-4-children-frontlines (accessed on 5 May 2020).

Montville, Joseph. 2016. The Moral Ties within the Family of Abraham: A Primer on Shared Social Values in Judaism, Christianity, and Islam. Journal of Ecumenical Studies 51: 245-56. [CrossRef]

Nussbaum, Martha. 2015. Political Emotions. Why Love Matters for Justice. Cambridge: Harvard University Press.

Omer, Atalia. 2015. Religion, Conflict and Peacebuilding: Synthetic Remarks. In The Oxford Handbook of Religion, Conflict and Peacebuilding. Edited by Atalia Omer, R. Scott Appleby and David Little. New York: Oxford University Press.

PAP. 2019. Ważny Dokument. Szef MSZ podpisał umowę z jedną z największych organizacji charytatywnych. Available online: https://www.polskieradio24.pl/5/1222/Artykul/2381438,Wazny-dokument-Szef-MSZpodpisal-umowe-z-jedna-z-najwiekszych-organizacji-charytatywnych (accessed on 16 March 2020).

Patisson, Stephen. 2019. UNHCR Names Nansen Refugee Award Regional Winners. Available online: https:/www.unhcr.org/news/latest/2019/9/5d7a4f264/unhcr-names-nansen-refugee-award-regionalwinners.html (accessed on 15 March 2020).

Petito, Fabio. 2019. Religious Engagement in International Relations: Overcoming secular blind spots and building a postsecular sensitivity in foreign policy. Paper presented at the International Conference Secularism as a Challenge for Politics and Political Science, Warsaw, Poland, December 12-13.

Petito, Fabio, and Scott M. Thomas. 2015. Encounter, Dialogue, and Knowledge: Italy as a Special Case of Religious Engagement in Foreign Policy. The Review of Faith and International Affairs 13: 40-51. [CrossRef]

Philpott, Daniel. 2000. The Religious Roots of Modern International Relations. World Politics 54: 206-45. [CrossRef]

Philpott, Daniel. 2002. The Challenge of September 11 to Secularism in International Relations. World Politics 55: 66-95. [CrossRef]

Pisarek, Adam. 2010. Przekroczyć gościnność. O granicach domu i państwa. Anthropos? 14-15: 27-32. Available online: http://www.anthropos.us.edu.pl/anthropos8/texty/pisarek.htm (accessed on 22 March 2010).

Pope Francis. 2017. The Message for the First World Day of the Poor: Let Us Love Not with Words but with Deeds. Available online: http://www.vatican.va/content/francesco/en/messages/poveri/documents/papa-francesco_ 20170613_messaggio-i-giornatamondiale-poveri-2017.html (accessed on 30 March 2020).

Putnam, Robert. 2001. Bowling alone. The Collapse and Revival of American Community. New York: Simon \& Schuster Paperbacks.

Ramsbotham, Oliver, Tom Woodhouse, and Hugh Miall. 2011. Contemporary Conflict Resolution: The Prevention, Management and Transformation of Deadly Conflicts. Cambridge: Polity Press.

Ratzinger, Joseph, and Jürgen Habermas. 2006. The Dialectics of Secularization: On Reason and Religion. San Francisco: Ignatius Press. 
Riccardi, Andrea. 2013. Introduction. In Making Peace: The Role Played by the Community of Sant'Egidio in the International Arena. Edited by Roberto Morozzo della Rocca. London: New City.

Risse, Mathias. 2008. On the Morality of Immigration. Ethics \& International Affairs 22: 25-33. Available online: https://www.carnegiecouncil.org/publications/journal/22_1/essays/001 (accessed on 12 March 2020).

Rolando, Francesco. 2018. Humanitarian Corridors to Italy. An Interview with Professor Paolo Naso. Harvard International Review 39: 64-67.

Safjan, Marek. 2018. Społeczeństwo obywatelskie w czasach kryzysu. Chrześcijaństwo-Świat-Polityka 22: 57-72. [CrossRef]

Saunders, Harold H. 2005. Politics Is about Relationships: A Blueprint for the Citizen's Century. New York: Palgrave Macmillan.

Seiple, Robert A., and Dennis R. Hoover. 2004. Religion and Security. The New Nexus in International Relations. Lanham: Rowman \& Littlefield Publishers.

Solarz, Anna M. 2012. Prymat prawa i moralności-Dziedzictwo myśli chrześcijańskiego średniowiecza we współczesnych stosunkach międzynarodowych. In Religia w Stosunkach Międzynarodowych. Edited by Anna M. Solarz and Hanna Schreiber. Warszawa: Wydawnictwa Uniwersytetu Warszawskiego.

Stensvold, Anne, and Ingrid Vik. 2018. Religious Peacemakers on the International Scene: Hopes and Motivations. The Review of Faith and International Affairs 16: 9-22. [CrossRef]

Surmacz, Beata. 2013. Kto jest dziś dyplomatą? In Nowe oblicza dyplomacji. Lublin: Wydawnictwo UMCS.

Szymczak, Wioletta. 2015. Społeczeństwo obywatelskie a religia. Typy relacji w perspektywie wiodaccych teorii socjologii religii. Roczniki Nauk Społecznych 2: 49-75. [CrossRef]

Thomas, Scott M. 2005. The Global Resurgence of Religion and the Transformation of International Relations: The Struggle for the Soul of the Twenty-First Century. New York: Palgrave Macmillan.

Tischner, Józef. 1998. Filozofia dramatu. Kraków: Znak.

United Nations. 2018. Report of the United Nations High Commissioner for Refugees. Part II. Global Compact on Refugees. New York: United Nations, Available online: https://www.unhcr.org/gcr/GCR_English.pdf (accessed on 22 March 2020).

Wilson, Erin K. 2011. Much to Be Proud of, Much to be Done: Faith-Based Organizations and the Politics of Asylum in Australia. Journal of Refugee Studies 24: 548-64. [CrossRef]

Wilson, Erin K. 2012. After Secularism. Rethinking Religion in Global Politics. New York: Palgrave Macmillan.

Wilson, Erin K. 2014. Faith-Based Organizations and Postsecularism in Contemporary International Relations. In Towards a Postsecular International Politics: New Forms of Community, Identity and Power. Edited by Luca Mavelli and Fabio Petito. New York: Palgrave Macmillan.

Wilson, Erin K. 2017. "Power Differences" and "the Power of Difference". The Dominance of Secularism as Ontological Injustice. Globalizations 14: 1076-93. [CrossRef]

(C) 2020 by the author. Licensee MDPI, Basel, Switzerland. This article is an open access article distributed under the terms and conditions of the Creative Commons Attribution (CC BY) license (http://creativecommons.org/licenses/by/4.0/). 

Article

\title{
Reassessing Religion and Politics in the Life of Jagjivan Rām
}

\author{
Peter Friedlander \\ South and South East Asian Studies Program, School of Culture History and Language, College of Asia and the \\ Pacific, Australian National University, Canberra, ACT 2600, Australia; peter.friedlander@anu.edu.au
}

Received: 13 March 2020; Accepted: 23 April 2020; Published: 1 May 2020

\begin{abstract}
Jagivan Ram (1908-1986) was, for more than four decades, the leading figure from India's Dalit communities in the Indian National Congress party. In this paper, I argue that the relationship between religion and politics in Jagivan Ram's career needs to be reassessed. This is because the common perception of him as a secular politician has overlooked the role that his religious beliefs played in forming his political views. Instead, I argue that his faith in a Dalit Hindu poet-saint called Ravidās was fundamental to his political career. Acknowledging the role that religion played in Jagivan Ram's life also allows us to situate discussions of his life in the context of contemporary debates about religion and politics. Jeffrey Haynes has suggested that these often now focus on whether religion is a cause of conflict or a path to the peaceful resolution of conflict. In this paper, I examine Jagjivan Ram's political life and his belief in the Ravidāsī religious tradition. Through this, I argue that Jagjivan Ram's career shows how political and religious beliefs led to him favoring a non-confrontational approach to conflict resolution in order to promote Dalit rights.
\end{abstract}

Keywords: religion; politics; India; Congress Party; Jagivan Ram; Ravidās; Ambedkar; Dalit studies; untouchable; temple building

\section{Introduction: Jagjivan Ram, Congress, and Ravidās}

Appleby (2006) has suggested that there are three ways in which religious leaders can be constructive builders of peace: first, by fostering the common good of the entire population; second, by their positions as key figures in a conflict; and third, by being repositories of local knowledge and custodians of culture. In this article, I suggest that Jagivan Ram's career fully matched each of these criteria. His political career was prefaced on the notion that only by the economic and social uplift of the whole of Indian society could the struggle for Dalit liberation be realized. His birth as a Dalit and status as a Dalit leader made him an authentic voice for Dalits in the government, and his embodiment of traditional forms of Dalit spirituality meant that he was uniquely well qualified to be a voice for a distinctive Dalit spirituality's perspective on peaceful conflict resolution through spirituality and affirmative action.

However, a central question that needs to be considered in relation to Jagiivan Ram is the following: what role did religion play in his career as an Indian politician? This is particularly because in his public life, over four decades throughout the numerous portfolios he held in Congress governments from 1946 to 1977, he seems to have been careful to maintain a distance between his personal religious beliefs and his political role as a facilitator in the uplifting of all communities in India. However, there are some indications that support a view that alongside his political career, he also acted as a patron for Dalit communities and, in particular, for Ravidāsī religious traditions. In addition, all of these relate to his reverence for Ravidās as an embodiment of a distinctive Dalit religious identity within Hinduism. While public perceptions of Jagjivan Ram as a politician normally focus on his role in secular society during the Nehruvian era, I shall explore here how his personal Ravidāsī religious beliefs impacted his political life throughout his career. 
One important implication of this, I suggest, is that it showed the way that Jagjivan Ram was able to find a peaceful and non-confrontational way within the Hindu caste establishment to protest against discrimination against Dalits in India and work for their emancipation.

\section{Jagjivan Ram and the Śiv Nārāyanī Movement (1908-1928)}

In this section, I will explore the relationship between Jagjivan Ram's religious identity and his emerging political identity during his childhood and formative years.

Jagjivan Ram was born into a family from the camār (hereafter anglicized as Chamar) community, which was commonly seen by higher caste (savarna) Hindus as associated with leather working and agricultural laboring. These communities were often described in Hindi as achüt ("untouchable") or aspriśya, a Sanskrit form of the same word. However, after 1928, Jagjivan Ram started to also describe himself as a Dalit, a Hindi word often translated as "oppressed". Jagjivan Ram's own translation of the term was "depressed", as in the name of his organization the dalit vārg lìg, the depressed classes league. However, it is notable that he also continued to use all three terms in his writings and speeches throughout his life when addressing different audiences. For instance, when addressing parliament in Hindi in 1981 and criticizing Indira Gandhi, he spoke of how the Muslims and his own community were both achüt, untouchables (Ram 2005, p. 312). Whilst in 1980, in his book on challenging the caste structure in India, he wrote about how his community had become "Asparshya" when India had been invaded by the Aryans in antiquity (Ram 1980, p. 10). This shows how Jagjivan Ram modulated his message for different audiences; for his own community, he was a Dalit; for sympathetic higher caste audiences, he was aspriśya; and for audiences whose views he wanted to criticize, he could self-identify as achüt, an untouchable.

Jagjivan Ram's father, Shobhi Ram, had served in the military and learnt English while stationed at Multan in the Punjab. During his period of service in the Punjab, he had met followers of the lower caste Hindu reformist Śiv Nārāyan̄ī tradition, which he then joined. It is of note that military service appears to have been one pathway through which some Dalits in nineteenth-century India were able to improve their status (Mendelsohn and Vicziany 1998, p. 88). Perhaps due to this, whilst Jagjivan Ram's family had been poor, they did own some land. Mendelsohn and Vicziany also noted that when they asked Jagjivan Ram about the discrimination that he experienced in his childhood, he said that in the village in Bihar where he grew up, it had been slightly less than that in some other areas. One instance of this, he told them, was that Chamars in his village had been allowed to draw water from wells in the common areas in the village (Mendelsohn and Vicziany 1998, p. 88).

For many, Chamars Ravidās (active circa 1450-1500) was regarded as a form of patron saint, as Ravidās was the most significant poet-saint, or sant (hereafter Sant), to have emerged from their community. The Hindi term Sant has a complex history but largely refers to followers of popular movements that developed from the fourteenth century onwards. This was led by Sants such as Nāmdev, a cotton printer from Maharashtra; Kabīr, a Muslim weaver from Varanasi; and Ravidās, a leather worker from Varanasi. There were also many women Sants, such as Sahajobāī and Dayābāî, who were from Rajasthani merchant communities. There were also some figures who are sometimes identified as Sants and sometimes as bhaktas ("devotees"), such as Mīrābāī from the Rajasthani kṣatriya community. The Sants emphasized reverence for the divine as a formless spirit equally present in all of humanity. Sants and bhaktas alike argued in favor of social equality and opposed any form of discrimination based on caste, class, gender, or religion.

Eleanor Zelliot and Rohini Mokashi-Punekar have argued that the untouchable Sants formed part of a movement whose characteristics included "acceptance of all castes and women into the fold of the saints", "a critical attitude towards orthodox religion", and the founding of "some sort of institution" (Zelliot and Mokashi-Punekar 2005, p. 14). Gail Omvedt has also argued that the development of anticaste intellectual movements in India from 1500 to 1750 emphasized "a strong form of devotional movement with a vision of equality, an emphasis on empirical thinking, and access to ecstasy for all." This was then followed by a phase during colonialism, up to around 1920, when "anticaste intellectuals 
had to form their own vision in confrontation with the developing 'Hindu nationalism' of the elite." (Omvedt 2008, p. 23). This would place the childhood and formative years of Jagjivan Ram in the era when the religious and political ideas of the Sant movements and their development during the colonial period were emerging onto the stage of Indian engagement with the freedom struggle.

Jagjivan Ram's daughter, Meira Kumar, in her description of Jagjivan Ram's childhood, emphasized that despite growing up amidst poverty, discrimination, and repression, her father Jagjivan Ram constantly struggled to overcome the challenges in his life. She also noted that he had been deeply influenced by his father having been a priest of the Siv Nārāyaṇi movement who spent his days writing out by hand copies of their sacred text anyās for use by followers of the tradition. Jagjivan Ram was a brilliant student and got the opportunity to go to the village school from the age of six and then on to middle and high school where he experienced discrimination. The discrimination included the provision of separate water supplies for Dalit students in schools. However, in an incident described in almost all accounts of his childhood, he would smash every pitcher of water set up for the use of only the Dalits each time it was set up and, by doing this, managed to persuade the school authorities to abandon this practice. She also gave an account of another incident from his childhood when he experienced discrimination on a family visit to a place called Khopira, where they owned some land. When they got to the village, they were asked to get down from the cart in which they were travelling, fold away their umbrellas, and walk through the neighborhood, as the local Brahmin community in that area maintained a traditional prohibition against Dalits riding in vehicles or using umbrellas (Kumar 2005, pp. 34-38).

Jagjivan Ram's father was a deeply religious person and a priest of the Śiv Nārāyaṇi Sant movement. In order to understand Jagjivan Ram's life, it is vital to realize that this movement provided a model for both spiritual belief and social reconstruction, which contributed to the base on which Jagjivan Ram also modeled his own actions. Because of this, it is essential to gain some understanding of this movement's history and characteristics.

Perhaps the earliest external accounts of the movement can be found in Horace Hayman Wilson's account of the religious groups he encountered in India in around 1828. According to Wilson, the main characteristics of the Śiv Nārāyaṇīs were that the community included Hindus, Muslims, Christians, and people from "the lower classes of the mixed population" (Wilson 1861, p. 358). Admission to the community was not through a guru but made by individuals joining a Śiv Nārāyan̄ī gathering, making offerings to a sacred text of the tradition, and listening to its teachings. The teachings stressed moral virtues including truth, temperance, and mercy, along with a prohibition on polygamy, and rather than having any special dress, the followers continued to observe the customs of the dress of Hindu and Muslim communities. The founder, Śiv Nārāyan, was a Rajput of the nerī̄ān lineage from Chandravan, a village near Ghazipur, and lived during the reign of Muhammad Shah (1702-1748). Wilson also noted that most of the Śiv Nārāyanīs were Rajputs and many were soldiers (sipāhi), whilst others were bearers (porters) and were found mostly around Ghazipur and in Calcutta (Wilson 1861, pp. 358-59).

The next account of the Śiv Nārāyaṇīs was prepared at the request of George Abraham Grierson (Grierson 1918). This was written by Babu Bajirangi Lal, who was on the municipal Board at Ghazipur, on the basis of enquiries he made from the Sant in charge of the local Śiv Nārāyan̄ī monastery, or dham. He said that the practices of the Śiv Nārāyaṇī community were still as described by Wilson, and they had four main centers in the Ghazipur region. However, by 1918, they had also built temples in Cawnpore (Kanpur) and in Bombay (Mumbai), and Śiv Nārāyan̄īs were found in Calcutta, Karachi, Rangoon, and other places. He also noted that there were Christian converts in the community from the town of Shahabad (now in the state of Haryana). He further commented that despite many of the community having been Rajputs in the past, now most were Chamars, dusādhs (another untouchable community of landless agricultural workers) and other untouchable communities.

Another account of the history, development, and characteristics of this movement was made by the Indian scholar Parasurām Caturvedī in his seminal work on the Sant traditions of Northern 
India, first published in 1952. There were several key points by which his account augmented what had previously been written.

First, he pointed to the continuities between earlier Sant religious practices, as advocated by Sants such as Ravidās and Kabīr, and those of Śiv Nārāyan (1716-1790). These included teachings based on the sabda, the divine sound and control of the breath through prānāyāma. He also noted the importance of sacred texts in the tradition and how these were connected with earlier teachings through a lineage that linked Śiv Nārāyan's's guru, Dukhhāran ("remover of suffering"), a Kayastha caste member from Baliya, with his guru Malukdās (1573-1671), who was also a Kayastha from Allahabad. Siv Nārāyaṇ was the author of numerous works and a tradition developed amongst each community, or samāj, of his followers to have as a central object of devotion a handwritten manuscript of one of his works, such as the guru anyās. Such texts also appear as a central feature of Jagivan Ram's childhood, and the creation of an authoritative sacred text for Ravidās also appears to have been a focus of interest for Jagjivan Ram.

Second, Caturvedī argued that on the basis of a study of Śiv Nārāyan's works, one of the main goals of his teaching was described as being the attainment of a state of entry into a world called sant vilās or sant des ("Sant's delight" or "Sant land"). This is the ideal true homeland of the Sants, which exists in a realm beyond the mundane world, which is called the kāl des ("the land of death") in which humanity lives ensnared in karma and delusion. The path to this ideal land was to be found by each individual through self-realization and through the abandoning of forty forms of faults such as drinking alcohol. This is a particularly important point as the idea of the attainment of liberation within life is also a key concept, which Jagjivan Ram mentions in his writings on the teachings of Ravidās.

Third, a key feature of Śiv Nārāyan's tradition was that it accepted followers from all backgrounds-Hindu, Muslim, and Christian—and did not discriminate against anyone based on caste or any other form of distinction and did not formally ask them to change any of their dress or customs or renounce their earlier religious affiliations. By the 1950s, only one-fifth of the movement was from high castes, and the majority were from jäti, such as "camār, dusādh and others who were considered untouchable" (Caturvedī 1972, p. 649). Women were also granted equal rights in the community and could, perhaps, he said, become heads of monasteries. The community also celebrated annual festivals on occasions such as the anniversaries of the birth, death, and enlightenment of Siv Nārāyan and the completion of the sacred text the guru anyās. These features of the Śiv Nārāyanī movement were also shared with followers of the Ravidāsī tradition and appear to be closely aligned with Jagjivan Ram's own views on how people from different castes and communities could work together.

Fourth, a key feature of Śiv Nārāyan's followers was that they focused not just on the spiritual wellbeing of their community but also on education, organization, and lobbying for their wellbeing in the world. Where there were sufficient numbers of devotees, they organized themselves into an association (sangathan), and the members would be called "sant sipāh" ("soldier Sants") and would elect an organizing committee, including a Mahant (priest), a Vazir (Minister), and other office holders. They would then raise funds, from which they would send a portion to a higher-level center of the movement, seeking registration, and then use the remaining funds for local community purposes (Caturvedī 1972, pp. 633-50). This aspect of the Śiv Nārāyanī movement also provided a model for the kind of political activities that Jagjivan Ram promoted through his establishment of Ravidās assemblies and the development of Ravidās temples as focuses for development of Dalit communities.

A more recent description of the role of the Śiv Nārāyanīs in the Dalit movements of Kanpur in the twentieth century is found in Bellwinkel-Schempp's work, where she described how their temple was an early center of Dalit activity in Kanpur. She also noted that whilst the movement had similarities to the Sikh movement, sometimes describing their sacred text as the Guru Granth, it was also very different, as it accepted aspects of the Vedic Hindu tradition and included many Tantric diagrams in its texts (Bellwinkel-Schempp 2007, p. 2178). 
From this account of the Śiv Nārāyaṇi movement, it can be seen that its program for spiritual and social reformation had numerous aspects that were similar to the path that Jagjivan Ram took in his own career.

The characteristic features of such movements included the following points: practices based on a spirituality that identified itself as a distinctive Sant tradition within Hinduism and the importance of authoritative sacred texts and temples. The ideas of the movement were also not solely spiritual but emphasized belief in the possibility that all of humanity could attain a home in an ideal world in which there was universal equality amongst all of those who followed the Sant teachings. The means for the attainment of this ideal state were based on the practice of a morality in which truth, non-violence, abstinence from intoxicants, and monogamy were key virtues. The movements also emphasised the creation of community through the celebration of annual festivals and building temples to foster the development of democratic representations of the community.

These descriptions of the changing characteristics of the Śiv Nārāyaṇi movement over time suggest that a change was taking place in Sant movements in the early twentieth century. After being primarily religious organizations in the eighteenth century, by the end of the nineteenth century, Sant traditions were transforming into organizations analogous to political movements. For Dalits such as Jagjivan Ram, they presented a model for how like-minded traditions could link together to build communities and to seek simultaneously the spiritual and social uplift of their communities in the world.

\section{Jagjivan Ram and Ravidās Sabhās and the Ravidās Jayantī (1928-1931)}

In this section, I will explore how, while Jagjivan Ram was a student, he deliberately linked his religious beliefs with his first steps into mass political activism.

Jagjivan Ram is often reported to have organized Ravidāsī sabhās (assemblies) in Calcutta from 1928 onwards and to have founded various organizations. Beltz noted that Jagjivan Ram founded the Ravidās General Assembly (Ravidās mahāsabhā) in 1928 (Beltz 2005, p. 100), whilst according to other authors, he also founded the All India Ravidās Assembly (akhil Bhārtiy Ravidās sabhā) in Calcutta in 1929 and then became the secretary of the All India Depressed classes league (akhil bhārtiy dalit vārg ligg) by 1935 (Kumar 2013, p. 51). Jagjivan Ram's wife, Indrani Ram, wrote in her memoirs that while studying in Calcutta from 1928 to 1932, Jagjivan Ram had been actively organizing Ravidās sabhās and attempting to unite different Dalit groups around the figure of Ravidās. In addition, he also promoted the celebration of Ravidās jayantī processions ("Ravidās Anniversary celebrations") (Ram 2010, p. 49).

In a description of such an assembly, Nau Nihal Singh wrote that in 1928, Jagjivan Ram "organised Ravidas's Sabhas in the various localities of Calcutta and received a good response. Once a big meeting was held in the Wellington Park in Calcutta and some 15,000 Achuts had gathered. The 20-year-old reformer, himself a college student, was to the audience their ideal and saviour". Singh also noted that Jagjivan Ram spoke out against meat eating and drinking alcohol, as he saw the abandoning of these practices as a "pre-condition for the uplift of the untouchables" (Singh 1977, p. 37). This description of the assemblies suggests the possibility that Jagjivan Ram's initial work in this area was both an expression of his own Śiv Nārāyan̄ī tradition and a development inspired by earlier caste assemblies by Dalit communities in Northern India.

The precise history of the holding of such assemblies (sabhā) and the related practice of anniversary (jayanti $\vec{l}$ celebrations is an area in which there is still much to be studied. The consensus appears to be that these forms of communal gatherings began, or perhaps took their present forms, only in the early twentieth century. Patel has argued that late-nineteenth-century higher caste assemblies served as models in Bihar for Dalit sabhā assemblies, which began in 1913-1914. In these meetings, caste elders called for abstinence from drinking, the practice of monogamy, and avoiding killing animals by poisoning them and claimed Brahman status for Chamars (Patel 2017, pp. 65-66). Then, groups such as the $d u s \bar{a} d h$ communities began to hold general assemblies, mahāsabhīa, every two years and began to claim that the $d u s \bar{a} d h$ s were not Dalits but actually a Kshatriya caste. 
Other Chamar leaders, such as Rāmcaran Kurīl, also began to organize Chamar Assemblies in locations such as Kanpur, where the first Ravidās Kurīl reform assembly (Ravidās Kurīl sudhār sabhā) was held in 1917. It should be noted that in descriptions of such assemblies written by Dalits themselves, they described them as not only aimed at reforming Dalits, as reported by authors writing about Jagjivan Ram's involvement in the assemblies, but also locations in which campaigns were developed against discriminatory high caste practices, such as bans on Dalits wearing jewelry or fine clothing (Dayāl 2006, p. 257). Kurīl then organized the second All India Ravidās General Assembly in Kanpur in 1935 and the fourth All India Ravidās General Assembly in Delhi in 1939 (Kurīl 1941, p. 6). Seen in this context, then, Jagjivan Ram's involvement in these assemblies should perhaps be seen as part of a broader movement at this time by Dalits in North India. However, what distinguishes Jagjivan Ram's actions is that, after he joined the Congress Party in 1931, he went on to set up the All India Depressed Classes League in Nagpur in 1935.

The beginnings of the practice of using processions honoring Ravidās jayantī, the anniversary of his birth and death in the Indian month of magh, as political demonstrations can be traced back to the first two decades of the twentieth century in Kanpur where the Ravidāsi leader Achutanand started the practice of taking out a public procession on the date of the Ravidās jayantī festival (Bellwinkel-Schempp 2007, p. 2178). This would suggest that Jagjivan Ram's efforts to promote the celebration of Ravidās jayantī in Calcutta in the 1920s were following an already existing model. The success of such actions was that they paved the way for the more widespread adoption of this practice across Northern India. When I was living in Varanasi in the 1980s, Ravidāsī community members also told me that the Ravidās jayantī celebrations had been a key way in which they claimed public space, as up to that time, caste Hindus in Varanasi had opposed Ravidāsīs gathering in public spaces in order to celebrate the Ravidās jayantī. Sangam Lal Pandey also mentioned in his work on Ravidās that he had attended such processions on Ravidās jayantī since 1954 in the Allahabad area, attended by thousands of Ravidāsīs (Pandey 1965, p. vii).

The role of Jagjivan Ram in encouraging the holding of Ravidāsī sabhās and the celebration of Ravidās Jayanti can be seen as an aspect of his political engagement that aligned with the trend of the era for mass mobilization. However, this is also another instance in which his own beliefs in relation to Ravidās and the precedents set by his Śiv Nārāyanī heritage clearly contributed to his vision for what he was doing. It is also notable that whilst his emphasis on morality and the abandoning of drinking appeared to suggest an alliance with the Arya Samaj's emphasis on uplifting the Dalits, his own Śiv Nārāyanī heritage already included these as key virtues that needed to be taken up by Dalits to facilitate their uplifting in society.

\section{Jagjivan Ram's Opposition to Conversion and Congress (1931-1936)}

Jagivan Ram's religious beliefs and his opposition to conversion were also vital factors in a speech he made in 1931, which appears to have been a key reason why he then joined the Congress Party and its struggle for Indian Independence. This address was made at a convention of the Untouchability Society in Patna in 1931, at which Rajendra Prasad, a key figure in Congress, was the chief guest. In his speech, Jagiivan Ram stressed that the time for Dalits

to be preached at by caste Hindus to give up eating meat, abandon drinking alcohol and live pure lives, now won't work any longer. Now Dalits no longer wish to be given sermons, they demand to be treated properly, not just words, there is a need for concrete action. M. Ali Jinnah is demanding a separate country for Muslims and Dr. Ambedkar is agitating for arrangements for separate electoral zones. I am opposed to all forms of religious conversion. We are untouchable (achūt) Hindus. We are born Hindus, and will stay Hindus and die Hindus. We created the nation; we were not created by the nation. [my italics] The nation is ours ... We must alert society against religious conversion. We must abolish untouchability. In the battle for freedom every religion and jäti must join together in great numbers. (Saran 2017, p. 137) 
I argue that a close reading of this speech points to two important points in relation to Jagjivan Ram's religious beliefs. First, that his opposition to conversion was based on his faith in being a Hindu and a particular sort of Hindu, an untouchable Hindu. This suggests that this speech can be seen as having been an assertion of his faith in Ravidās and the teachings of the Sants.

Second, his belief that India was created by untouchable Hindus is a crucial point. This idea was a key feature of Dalit ideology in the twentieth century. Dalit leaders interpreted the then popular accounts of an Aryan invasion of India as accounts of how the Dalits were India's original inhabitants and that higher caste Hindus were descendants of foreign invaders who had settled in India.

It is important to note that the context for this opposition to conversion was not related to his later disagreements with Ambedkar. Rather, it sprang from opposition to conversion in a broader sense. In a different account of this speech, he was said to have also opposed specifically the conversion of Dalits to Islam, Christianity, and Buddhism, which would have reflected the experiences of Dalits at this time in Northern India who were the focus for conversion movements organized by many different religions.

After giving this speech, Jagjivan Ram went with Rajendra Prasad to Bombay in 1931, where he met Mahatma Gandhi, joined Congress's freedom struggle, and was given responsibility for Gandhi's Harijan Sevak Sangh (“Union for uplifting the untouchables”) in Bihar (Maurya 2010, pp. 30-31).

\section{Re-Evaluating Jagjivan Ram and Bhim Rao Ambedkar (1936-1955)}

Almost all discussions of Jagjivan Ram's life include discussions of the significant differences in ideas between Jagjivan Ram and Bhim Rao Ambedkar (1891-1956), as both were, each in their own way, two of the most significant Dalit leaders in twentieth-century Indian politics. The key difference between them was that in 1936, Jagjivan Ram and Ambedkar parted company over their views on the role of religion in the Dalit struggle for rights. This arose because of Ambedkar's announcement at the Yeola Conference in 1935 that although he had been born a Hindu, he would not die a Hindu. He then made a number of speeches over the next few years explaining why he and his followers should renounce Hinduism, as within it there was no possibility of emancipation, and instead, they should adopt a new religion (Beltz 2005, pp. 50-58). However, Jagjivan Ram rejected Ambedkar's view and in public speeches said that even if Dalits converted to another religion, they would still suffer from the stigma of untouchability and risk alienating other Hindus (Nath 1987, p. 194). His widow, Indrani Jagiivan Ram also wrote about this issue in her biography and described how Ambedkar had tried to persuade Jagjivan Ram at the time to follow his lead. However, Jagjivan Ram argued with him that even when Dalits converted to other religions, such as Sikhism, they were still discriminated against within Sikhism and that converting was running away from the problem, and the only solution was a change that effected the whole of Indian society (Ram 2010, pp. 52-53). As previously argued in Section 4, Jagjivan Ram's views on conversion did not arise due to his disagreement with Ambedkar but were part of his fundamental religious beliefs.

Politically, the results of this conflict were that Ambedkar went on to found an independent political party, the Republican Party of India, and spent most of the rest of his life fighting for Dalit rights from outside of the political mainstream, whereas Jagiivan Ram became the most prominent Dalit leader within the Congress party and continued his struggle for Dalit liberation from within the ruling party for most of his life.

There has been considerable academic discussion of the contributions that Ambedkar and Jagjivan Ram made to the Dalit movement. Jaffrelot even went so far as to write about Jagjivan Ram's contribution to Dalit movements in India under the heading "Stooge of Congress?" (Jaffrelot 2003, p. 97). His argument was that Jagjivan Ram's foundation of the Ravidās Mahāsabhā ("Ravidās general assembly") while he was studying in Calcutta in 1928 was part of a social reform effort based on Sanskritization, emulation of high caste Hinduism, rather than radical opposition to caste Hinduism as advocated by Ambedkar (Jaffrelot 2003, p. 98). He then highlighted the way that Jagjivan Ram had joined the Congress party in 1930 and adopted a Gandhian approach to challenging caste. Jaffrelot's 
proposition was that the Congress party attempted to use Jagjivan Ram as a counterweight to the growing strength of Ambedkar's more radical approach to challenging caste in India. In support of this, he suggested that the foundation of the All India Depressed Classes League during a Ravidās Mahāsabhā meeting in 1934 had inherent in its constitution a program of Sanskritization by untouchable Hindus rather than Ambedkar's basic program of challenging the very existence of the caste system. His conclusion was that Jagjivan Ram's advocacy of a Gandhian approach to Dalit uplift meant that, in the long run, his career in the Congress party did little to further the interests of Dalits within the Congress agenda and more broadly in India as a whole (Jaffrelot 2003, p. 102). Some authors have also suggested that his contribution to Dalit liberation was somewhat constrained by his role within the Congress party and that the longevity of his career was due to both "his competence and also his carefulness not to engage in dissent and controversy and that it was hard to estimate how much power he wielded within the Congress party over the years" (Mendelsohn and Vicziany 1998, pp. 207-8).

Against this, there are many other authors who have pointed to the positive contributions that Jagjivan Ram made to India through his political career, in particular as the Minister of Agriculture during 1967-1970 and as the Minister of Defense during the Indo-Pakistani war of 1971 during the struggle by Bangladesh for independence.

There are also some Dalit writers who have also made positive evaluations of Jagjivan Ram's contribution to the Dalit struggle in India. Notable amongst these are Sanjay Paswan and Pramanshi Jaideva, who included a substantial section on him in their Encyclopaedia of Dalits in India (2004). They situated him as having been a post Ambedkar Dalit leader and noted that Ambedkar had "once called him the champion of the Dalits" (Paswan and Jaideva 2004, p. 15). In the section of their chapter on Jagjivan Ram, under the heading "Dalits and Jagjivan Ram", they highlighted his work to set up structures to ensure minimum wages for all agricultural laborers, including Dalits from the 1930s to the 1950s (Paswan and Jaideva 2004, pp. 82-87). They then pointed out in a section on "Babu Jagjivan Ram as the Champion of the Dalits" that his contributions as Railway Minister led to the starting of the Indian Railways food services in which Dalits, were, for the first time, able to eat with higher caste people all over India. In addition his foundation of the Dalit Varga Sangh ("Depressed Classes Union") was a significant step towards the economic uplift of the Dalits (Paswan and Jaideva 2004, p. 88). In a section on "Jagjivan Ram, the man", they pointed to how he was praised for his hard work and skillful handling of parliamentary work (Paswan and Jaideva 2004, pp. 89-91).

They then turned to the relationship between his support for Hinduism and his political achievements. The crux of the issue, as they saw it, was that he was a theist and "many of his friends were not able to reconcile themselves to his blind faith and devotion to Rama" (Paswan and Jaideva 2004, p. 92). They singled out, in particular, that his faith in the story of Ram was not shaken by its anti-Shudra elements and that "[r]ecitation of quatrains and couplets from the Ramcharitmanas formed an essential part of Jagjivan Ram's daily routine" (Paswan and Jaideva 2004, p. 93).

It is striking that for these Ambedkarite writers, there was no doubt that his Hinduism was very much part of his identity, but that it was for them a problem, as it conflicted with Ambedkar's rejection of Hinduism. However, they reconciled the two positions by arguing that he said that Rām treated all alike and cited a famous passage in which Rām spoke with a bhīlini, a tribal woman, due to which he said that "Rama treats all his devotees, whether high-born or low born alike as He told to Bhilini" (Paswan and Jaideva 2004, p. 92). The importance of the Rāmcaritmānas in lower caste Bihari religious practices in the nineteenth century is also clear from the critical role it played in the Hinduism of the bonded laborers who left India in the nineteenth century to work in Mauritius and Fiji.

They also noted the relationship of the Sants to Hinduism and mentioned how Kabīr, Nāmdev, and Ravidās were "neither kings, nor members of a high caste, still the world holds them in great veneration" (Paswan and Jaideva 2004, p. 91) and that there was "a striking affinity between Kabir's creed and Jagjivan Ram's ideology" (Paswan and Jaideva 2004, p. 94). 
This work is an important link to ways in which some modern Ambedkarite followers now reconcile Jagivan Ram's and Ambedkar's ideas and see Jagjivan Ram as having been both a significant political leader and a follower of a distinctive Sant form of Hinduism.

It is also of note that many Dalit and Chamar groups also regarded Jagjivan Ram as a kind of patron for their activities. Johannes Beltz noted in a description of the Chambhars (Chamars) of Maharashtra that whilst the Mahār community regarded Ambedkar as their patron, the Chambhars regarded Ravidās and Jagiivan Ram as their leaders and wanted to continue to assert their Hindu and Chamar identity (Beltz 2005, pp. 98-100).

I would argue that Jagjivan Ram's disagreement with Ambedkar over the issue of conversion was not the result of his acceptance of caste Hindu ideology, but derived from his own Siv Nārāyan̄ī and Sant heritage. In particular, it is important not to conflate his particular vision of Dalit Hinduism with the views of higher caste Hindus. Seen in this light, he was not arguing that Dalits should accept caste Hindu views on what constitutes Hinduism, but, rather, he held to a desire to maintain beliefs inherited from his Śiv Nārāyaṇi and Sant heritage.

In particular, his public espousal of the idea that Dalit uplift would only be possible as part of universal uplift seems to echo Śiv Nārāyanī beliefs that real change could only come about when all Hindus accepted the validity of the Sant teachings of universal equality.

\section{EEāstri and Pāṇdey's Sant Ravidās aur unkā kāvya (1956)}

Eāstri and Pāndẹ's Sant Ravidās aur unkā kārya (Sant Ravidās and his poetry) was the earliest serious modern Hindi academic study of Ravidās's life and works. It contained a study of the teachings of Ravidās and his life and works and included a pioneering attempt to edit a critical text of his verses based on manuscript sources. Jagivan Ram wrote a preface to this volume, in which he started by explaining his views on the origins of the teaching of the Sants and stressed the difference between their teachings and those of what he saw as a "distorted", khalmal, orthodox Hindutva.

There is no unanimity amongst academics about the origin and development of the Sant movement. However, it is universally acknowledged that their works express the consciousness of the masses. In them there was a demand for a new social reformation, and a call for natural equality and a constant appeal for leadership which was not based on separation and discrimination, but on the ideal of unity. These teachings fanned the embers of awakening and while some were slowly extinguished others continued to burn bright and cast their light abroad. But no flame leapt up which could burn away all of the foulness of Hindutva. (Śāstri and Pāṇdey 1956, p. i)

It is notable that he is clearly distinguishing here between what he saw as true Hinduism, that of the followers of the Sants, and a distorted (khalmal) Hinduism as propagated by the supporters of Hindutva. The word khalmal is not common in Hindi but occurs several times in one of Jagjivan Rām's favorite works, Tulsīdās's Rāmcaritmānas. In this, the adjective khalmal is used when describing a mentality that is distorted and polluted as in a verse where somebody is cursed to become a snake with a distorted and polluted mentality (sarpa hohī khalmal mati byāpī, Tulsīdās 1968, p. 1061).

The term Hindutva had been coined by Vinayak Damodar Savarkar in a pamphlet in 1923 to mean a particular view of Hindutva "Hindu-ness" (Savarkar 1923). This corresponded with his political and religious agenda, which favored a redefinition of India as an ethnic Hindu state in which primacy was given to the authority of caste Hindu traditions and interpretations of Hinduism. This then became the guiding principle for many of the right-wing Hindu fundamentalist movements, which came to form the rāstrinya svayamsevaka sangha, the National Volunteer League, which is most commonly known as the RSS. Jagjivan Ram's rejection of Hindutva and its ideology is clear from the way that he speaks of it as khalmal, defiled or distorted, Hinduism, which suggests that he saw supporters of these organizations and supporters of Sant movements as fundamentally at odds with each other's teachings. 
Jagjivan Ram argued that the teachings of the Sants were also expressions of fundamental truths that were compatible with those found in orthodox Hindu sources, such as the Upanisads and Vedas, but not derived from them. Furthermore, he then said that it was regrettable that no authentic work on Ravidās had been compiled before this volume and expressed delight that "for the first time in centuries the authors have rectified this shortcoming" (Śāstri and Pāndey 1956, p. ii). He concluded by expressing his support for the need to universally acknowledge the debt that not only "Ravidāsī brothers" but all of humanity owes to Ravidās:

I want to say a few words about the natural connection which exists between Ravidāsī brothers and this great man. It is not just Ravidāsīs, who should revere Mahatma Ravidās, he should be revered by all of humanity. He attained that state beyond where caste and nationality etc. can reach and he attained that which lies beyond all such base sentiments. To keep alive the memory of Ravidās is not just the duty of Ravidāsīs, it is the responsibility of all of India's inhabitants. The present generation's orientation towards Sant literature is a sign of the thought-revolution we can see manifesting before our eyes and the expression of the success of this is leading to the foundation of a new society in which for the first-time mankind will attain liberation.-Minister for Communications, Indian Government, New Delhi-Jagjivan Ram

As if to also emphasize that he is writing not just as a private individual but as a representative of the Indian state, he also included his official title in his signature to this preface. It is also notable that whilst such clear expressions by Jagjivan Ram of his respect for Ravidās are not as well known as his parliamentary career, it is clear that when he did make them, their import was evidently considerable, as they showed that even from within the government, there was support for the followers of Ravidās.

It is also striking that his support for the idea of creating an authoritative text for Ravidās aligned well with his Siv Nārāyaṇī respect for sacred texts as a key element in religious traditions. Jagjivan Ram's introduction to this pioneering attempt to create an authoritative version of the works of Ravidās highlighted his continuing public support for the Ravidāsi tradition. It indicates that between 1928, when he was promoting Ravidās sabhās, and 1956, when he wrote the introduction to this book, he continued to strongly support the teachings of Ravidās. This highlights the way in which, although the normative depiction of Jagiivan Ram in most accounts of his parliamentary career does not mention the religious values he inherited from his family's reverence for Sant traditions, they still continued to function as the fundamental ground on which he situated his political career.

\section{Jagjivan Ram and the Tughlaqabad Temple in Delhi in 1959}

A series of events in 2019 also pointed out the importance that Jagivan Ram's endorsement of Ravidāsī activities had in the 1950s and, perhaps, how the impact of a lack of a similar voice today has changed the situation for Dalits and Ravidāsīs in modern India. The key issues here relate to a Ravidās temple, which was outside the Tughlaqabad Fort in Delhi and which had been established there by the early nineteenth century but was demolished by the Delhi Development Authority (DDA) in 2019.

An article in the Indian Journal The Caravan, gave a good account of how the temple had come to be built. Rishi Pal, the president of the managing committee of the temple in 2019, described how his ancestor Roopanand, in around 1830, had built a hut by a pond outside of the Tughlaqabad Fort. He then started to perform public religious rituals at the site, which was associated with two Ravidāsī oral traditions about the pond: first, that it had healing waters that could cure leprosy and second, that it was the site where Ravidās had given teachings to Sikandar Lodhi, the Sultan of Delhi, in the fifteenth century, who had then granted the land to Ravidās and his followers. There were also memorials to Roopanand and three successive temple priests at the pond, and part of a temple at the site was probably constructed in around 1905, on the basis of the bricks dating from 1905 used in the construction of the temple. After independence, the local Dalit community in the area restored the temple and, on 10 February 1959, they sent a letter inviting Jagjivan Ram to inaugurate the new 
temple, which he did on 1 March 1959. In 1960, the site was registered in their possession (Sagar 2019). However, 26 years later, in 1986, the year of Jagjivan Ram's death, the DDA began disputing their possession of the land. This was then followed by three decades of legal disputes, which ultimately led to a supreme court ruling against the temple committee and the temple's demolition on 10 August 2019.

The story of the Tughlaqabad Ravidās temple points to the way that Jagjivan Ram was able to support Chamar and Ravidāsī activities during his lifetime. His inauguration of the Tughlaqabad Temple had been part of a process of its legitimization during his lifetime. However, the changing circumstances in India, and perhaps the lack of strong Dalit voices in the ruling parties of India by the twenty-first century, eventually led to the demolition of this historic temple.

\section{Jagjivan Ram in the Ravidās Memorial Movement (1976-1986)}

Jagjivan Ram played a key role as a supporter and coordinator of the movement to build a Ravidās temple at Rajghat in Varanasi from 1976 until his death in 1986. One of the leading figures in this movement was Rāmlakhan (note that many Dalits do not use a surname, which is often a form of caste title in India). He was a former Uttar Pradesh Agriculture and Irrigation Minister, who took a leading role in the organization of this project. In an article in Ravidās, the magazine of the Ravidās Memorial Society, he described the project as being carried out under the support and direction (sahyog aur samraksan) of Jagiivan Ram and having been intended to provide a venue in central Varanasi in honor of Ravidās, as opposed to the temple to Ravidās at Seergovardhanpur to the South of the city (Rāmlakhan 1986a, p. 68). In a separate pamphlet about the project, he also described in detail how the land had been bought and registered in 1976 in the name of the "Ravidās Memorial Society" (ravidās smārak sosaițī) in Delhi and how Jagjivan Ram had laid the foundation stone on 12 April 1979 at a ceremony during a conference of the All India Ravidās General Assembly (akhil bhārtiy ravidās mahā-sammelan) (Rāmlakhan 1986b, p. 5). In personal communications to me when I visited the temple at that time in 1986, Rāmlakhan also told me that Jagjivan Ram had been the main donor who purchased the land for the temple and facilitated its purchase (Rāmlakhan, personal communication, 1986).

The context for this development was in part related to the political developments of the era. Although Jagiivan Ram had been a supporter of Indira Gandhi from when she came to power, he did not approve of her declaration of an emergency in 1975. This led to his resignation from the Congress party in 1977, demanding that she cancel the emergency and restore democracy. It was in this era of uncertainty that he also apparently started his involvement in this project to build a Ravidās temple in Varanasi. A further factor in this may have been that, as he was no longer concerned about his position in the Congress Party, he was finally able to begin to move away from abstaining from actions that did not support his public persona as a secular politician and act in ways that were more in accord with his reverence for Ravidās.

\section{Jagjivan Ram's Caste Challenge in India (1980)}

In addition to his public support for a Ravidās memorial project from 1976 to 1986, during this period, he also wrote a book called Caste Challenge in India (Ram 1980). In this book, he put together a carefully constructed discourse, aimed at non-Dalit readers, which set out his understanding of how caste discrimination arose and how it should be challenged.

He started from the standpoint that there was a tendency in all cultures for the development of inequality. However, he argued that when the Aryans entered India, they had only three castes, Brahmins, Kshatriyas, and Vaishyas, but after they clashed with the aboriginal inhabitants, the Shudras and those excluded from society came into being and became the "Asparshyas or the panchama" (the untouchables or the "fifth"). This system was then codified by the Brahmans and people were conditioned by belief in karma and rebirth to accept the new system. There were, however, revolts against this system, and the Buddha attempted to reform it, but did not succeed. Then, later reform movements fought against this system led by saints, such as "Ramananda, Kabir, Ravidas (Raidas), Eknath, Tukaram, Chaitanya, Nanak and many others", and all of them "sought to reform the people 
of the country and inculcate in them a new belief in the equality of all men before God." However, these movements did not fully succeed, as they were transformed into sects within society, rather than reforming society as a whole (Ram 1980, pp. 10-14).

The main chapters in the book carefully examine the issues facing India due to discrimination on the basis of caste. However, it is notable that his vision of a casteless society is ultimately based on a vision of an egalitarian society where all have equal economic abilities, and in order to achieve this, there will be a need for a three-pronged attack upon the caste system, based on legislation, economic development, and reservations for downtrodden members of society. It is only in this way, he argued, that prejudice against the formerly downtrodden members of society would be forgotten, and "we shall not only succeed in creating a new social and economic life in this country, but also in giving a decent burial to a system which has defied the endeavors of saints and savants from Lord Buddha to Mahatma Gandhi" (Ram 1980, p. 67). Key to understanding this book's message is that, unlike Ambedkar's rejection of Hinduism, Jagjivan Ram presented in this work his own approach to challenging caste in India, which preserved the diversity of Hindu religious traditions that was central to Jagiivan Ram's spirituality.

\section{Jagjivan Ram's Ravidās as a Symbol of Identity (1986)}

In 1986, the year that he passed away, Jagjivan Ram presented a much more radical public presentation of his ideas on the importance of Ravidās than he had in 1980. This was a Hindi language article in the magazine Ravidās called "Guru Ravidās as a symbol of identity for the embodiment of the divine" (Ram 1986). The term I have translated here as "embodiment of the divine" is in Hindi issvar ke aṃ́dharom, literally "embodiments of a portion of God". The idea that all living beings are equal embodiments of a portion of God is central to Ravidās's teachings and is found in a Ravidās verse in the Sikh sacred text, the Śrī Guru Granth, where Ravidās said that "Ravidās teaches to all, the divine is equally present in all" (sam dal samjhavai kou, see Callewaert 1996, p. 93). This is a key teaching, as it implies that the divine is equally present in all, from the highest caste Brahmin to the lowest castes, such as Chamars.

In this article, Jagjivan Ram laid out much more clearly than in his 1980 English language publication, his vision of the historical relationship between spirituality and social inequality. His basic position was that the desire for equality was present in all world societies, but that in India, the Aryan invasion had replaced the values of the original inhabitants of India with those of the Brahmins and their caste system. He then described the teachings of the original Indians as forms of tantra. It should be noted that his use of the term tantra here was not intended to be derogatory, as some modern Indians see the term, but was being used in the way it is sometimes used to describe the Sant teachings, as mentioned in relation to Śiv Nārāyan̄i sacred texts by Bellwinkel-Schempp (2007). Moreover, he does not appear to have been using this term to suggest any shortcomings in the original teachings of the aboriginal $(m \bar{u} l n i v \bar{a} s \bar{l})$ inhabitants of India but, rather, using tantra as a term to describe the inner spiritual practices of the Sants, such as sabda yoga and their views on the fundamental equality of all people.

However, Jagiivan Ram's message has been, on some occasions, misunderstood. This can be seen from a Government of India publication by Om Prakash Maurya translated into English by Rupali Kishore, which contains a translation of part of Jagjivan Ram's 1986 article. However, the translation completely alters the meaning of what Jagjivan Ram wrote. In particular, perhaps due to the translation process, the notion that the religious system of the aboriginal inhabitants of India was a form of tantra is transformed into Jagjivan Ram writing that the aboriginal inhabitants of India had been followers of "black magic" (Maurya 2010, p. 193). This mistranslation points to a larger problem; when considering the political career of Jagjivan Ram, some Hindu authors conflate Jagjivan Ram's faith in Ravidāsī and Śiv Nārāyaṇ̄ Sant traditions with the beliefs of followers of orthodox high caste Hindutva Hinduism. This means that public perceptions of the role of religion in Jagjivan Ram's life run the risk of conflating 
Jagjivan Ram's own spirituality based on the Sant tradition with forms of Hindutva ideology that he specifically rejected in his 1956 preface to Śāstri and Pāṇdey (1956) work on Ravidās.

Reporting of his spirituality also often conflated his reverence for the Hindi work the Rāmcaritmānas with the Sanskrit epic the Rāmāyana. For instance, his long-time associate Nau Nihal Singh, who was Deputy Secretary of Indian Council of Scientific and Industrial Research, described Jagjivan Ram as a vaiṣnava sagunopasaka (a worshipper of forms of Viṣnu with attributes) whose daily religious practices included recitations from Tulsīdās's Rāmcaritmānas (Singh 1977, pp. 11-12). He also mentioned that, like Kabīr, he "condemned the evils that have crept into Hinduism" and he "follows the dictates of a small voice even if they run contrary to the commandments of the "Shastras'"' (Singh 1977, p. 13). He also pointed out that he would quote verses by Kabir "who was a favorite of his father" (Singh 1977, p. 108). This appears to have been an account of his spirituality that retained an accurate description of how his practices reflected Sant spirituality.

In contrast, Triloki Nath Chaturvedi who was Governor of Karnataka in 2005, when speaking about Jagjivan's religious life, said "Ramayana was a great favourite. When Ramayana Paath, took place at his house on Sundays, he would read out to the gathering the meaning of each verse in the epic" (Chaturvedi 2005, p. 55). This seems to conflate his Sant spirituality with a perception of him as an orthodox Hindu.

In his 1986 article, Jagjivan Ram then developed his argument in more detail about how from the moment that the caste system had been introduced into India, opposition to it from the Dalits had also begun, in particular, in the medieval period, led by Sants from all corners of India. The Sants rejected the roots of the caste system and argued in favor of a liberal egalitarian religion that was different from that espoused by the false and empty forms of caste Hinduism that had infected India. Central to this struggle, he suggested, was that Ravidās, a Chamar, had taken on the proponents of caste Hinduism in their central fortress, the city of Varanasi. Key to this struggle, Jagjivan Ram argued, was the centrality in Ravidās's teachings of a denial of there being any different castes; instead, Jagjivan Ram said Ravidās proclaimed that we were all of the same flesh and blood, and rather than belonging to different castes, such as Brahmin, Kshatriya, Vaishya, and Shudra, all humanity belonged to only one caste. Jagjivan Ram also argued that this was a core teaching of Sants, such as Ravidās, and Sants who had Muslim backgrounds, such as Kabīr, and that both Kabīr and Ravidās alike had argued for Hindu Muslim equality and unity. He then cited a number of verses by Ravidās and his contemporaries, which witnessed to the truth of what he was arguing.

The sources of these verses which he quoted were not given, and mostly they do not match with any particular textual tradition that I can identify. From various features of the Hindi language in them, such as the inclusion of modern forms of some words, it also appears possible that they were, in some cases, drawn from contemporary oral traditions. His argument could perhaps be read as meaning that Jagjivan Ram's own views were also the views of Ravidās. My translation of some of the core of this article dealing with caste discrimination is as follows. Jagjivan Ram began by citing verses from Kabīr, Ravidās, and Nāmdev, which argued against discrimination by jāti, caste, or birth:

Ravidās, did not directly attack [the institution of caste] or like Kabīr say.

'When did you become a Brahmin, when did we become Shudras?

When did we become blood, you become milk?

If Brahmins are born different,

Why aren't you born from a different way?'

Ravidās said.

'Don't ask what caste a man is born in, what is jāti or community ( $j \bar{a} t i k \bar{a}$ pat)? O Ravidās! All sons are sons of God, none is high or low born.' 
And.

'All alike are tangled up in the deception of caste and community, all of humanity has been afflicted by the disease of jäti.

O Ravidās! Don't ask about jāti, what is jāti or community.

Brahmin, Kshatriya, Vaishya or Shudra, all are only one jāti.'

Kabīr also spoke about this.

'Only one breath, only one essence, only one flame in existence.

All beings are made from only one substance, by only one Creator.'

Ravidās said.

'There are $j \bar{a} t i s$ in $j \bar{a} t i s$,

like leaves within leaves in a banana plant.

O Ravidās! Men cannot be united,

as long as there is jāti and community.'

Kabir also expressed similar sentiments.

'Don't ask a sadhu his jāti, ask about his wisdom.

Learn the value of the sword, don't pay attention to the scabbard.'

No Sant gave any importance to jāti. Nāmdev also said.

'I came to your door laughing and playing,

Practicing devotion "Nāmdev" was lifted up.

My birth was in a low jäti,

what does it matter if I was born a calico printer?' (Ram 1986, pp. 72-73)

Jagjivan Ram pointed out that the Sants had argued against discrimination based on religion. The term he used for "respecting all religions" (sarva dharma sambhava) had been coined by Gandhi, showing Jagjivan Ram's debt to Gandhian thought. However, Jagjivan Ram also pointed to a lack at the heart of formal religions, as he spoke about how there was "hollowness" (khoklepan) at their heart, but that the hollowness found in Islam and Hinduism was not found in Ravidās's teachings:

Ravidās also couldn't keep silent about respecting all religions,

or their hollowness.

'O Ravidās! He who is my Ram,

He is also Rehman.

The Kāba and Kāśī, know this about them,

they are both the same.'

And also:

'There is nothing distasteful in a Mosque, and nothing lovely in a temple.

Neither Allah nor Ram dwells in either, says Ravidās the Chamar.'

In an era when the importance of recognizing Hindu-Muslim unity was not recognized he [Ravidās] also revealed his humanitarian character.

‘Be a friend to Muslims, have affection for Hindus. 
O Ravidās! The light of Ram shines in all, all our friends.'

'Both paths are based on practice,

this is the strange drama the Creator established.

Hindus and Turks are one and the same,

brother! Ravidās declares this truth.'

'O Ravidās! There is no difference!

Between gold and a golden bracelet,

Just as there is no difference between Hindus and Turks.'

Jagjivan Ram then continued and said that "Ravidās believed in the religious tradition which had been developed by the original inhabitants of this land before the arising of Vedic religion and which contained truths which, when the Aryans encountered them, led to them creating their six philosophies and Upanishads." (Ram 1986, p. 74).

Finally, he cited one of Ravidās's most well-known verses, which was found in the Sikh sacred text the Adi Granth and in manuscripts from Rajasthan and UP and in print editions from around 1900 onwards. The version Jagjivan Ram cited is not exactly the same as any that I have seen in any print edition of Ravidās's works but is substantially the same as the version found in the Adi Granth. This verse had become central to the followers of Ravidās in the twentieth century as the key vision in Ravidās's works of the social, as well as a spiritual, revolutionary message taught by Ravidās. My translation of this passage is as follows:

The practice of the original inhabitants of here [India] was based on unbiased egalitarianism. The Sants were the fosterers of that tradition. They wanted to re-establish the religion and society which had been current in this land before the arrival of the Aryans. It was because of this that Ravidās proclaimed.

'Now I have found a home in my true homeland.

O brothers! There is always peace in that land.

That town is called "The Sorrowless City"!

There is no care or anxiety there.

No levies, no taxes, no duties.

No fear of failure or dread of loss.

The sovereignty there is fixed and stable.

None are second or third, all are as one.

It is forever flourishing and eternally renowned.

The dwellers in that town are always wealthy.

They wander around wherever they please.

None stop them from entering any of the palaces there.

Ravidās, the liberated Chamar says,

Whoever is my fellow citizen of that city,

They are my friend'. (Ram 1986, p. 74)

This verse contains a reference to a city called, begumpura, which became a kind of motto, or slogan, for the ideal that was hoped could be attained by the followers of Ravidās. The Hindi word begumpura could be understood as meaning different things depending on whether the word begum was taken to mean either "queen" or "sorrowless". Due to this, the city can be imagined as being called "The Sorrowless City" or "The Queen's City", or perhaps it could simply be understood as meaning "The city free from suffering". During the twentieth century, this verse came to be seen over time as representing Ravidās's ideal for how society should be structured. The key features read as being implicit in this verse were the creation of a society with no discrimination against anybody, with economic stability and good fortune and with the freedom for even a "liberated" Chamar to enter the public spaces in the world. This imagery, it should also be noted, was also found in Śiv Nārāyaṇ's vision of the "Land 
of the Sants" (sant des) and was a common image in Sant teachings. Due to this, it would have been familiar to Dalits from diverse communities as a commonly held vision for the possibility of, not just spiritual, but actual, liberation in this life.

Jagjivan Ram's conclusion was that the depressed classes (dalit samudāy) were now searching for their identity in contemporary India. Furthermore, in their search for humanitarian values and egalitarian traditions, it was essential for them to first explore their own history-a history that had been effaced and distorted by conquerors. He concluded as follows:

[I]n the lines of history written by the conquerors our history can also be seen, and even in the texts which advocate the caste system, such as Manusmriti, the rebellion against the system can be seen as a proof of the indomitable spirit of its opponents. (Ram 1986, p. 74)

The Sant tradition, he concluded, was a witness to the struggle of the countless masses who had been deprived of their human rights as embodiments of the divine. From amongst all the Sants, Ravidās also stood out as having been a shining pillar of light in their tradition that stood for the following:

$[\mathrm{H}]$ armony, peace, critical intellect, stability, resistance, unwaveringness, humanity, equality, and the living presence of the gem of the divine dwelling within humanity (Ram 1986, p. 74)

Jagjivan Ram's essay from 1986 presented the clearest picture of any of Jagivan Ram's writings about how his vision of Ravidās's thought related to his vision of the world. It also, in almost every way, aligns with the teachings that I suggest could be found to have influenced Jagjivan Ram through his family's Śiv Nārāyaṇī background, but now focused on Ravidās, rather than Śiv Nārāyaṇ, as a symbol for how liberation was possible in life, in both the spiritual and mundane realms of the world itself.

\section{Conclusions: Jagjivan Ram as a Ravidāsī Politician}

In this paper, I have considered the relationship between peace, politics, and religion in Jagivan Ram's life. His life presents an important example of how religion and politics can contribute to peaceful approaches to conflict resolution. Confronted by the problems inherent in being Dalit in the twentieth century, a lack of critical power in society, he adopted non-confrontational strategies that avoided any sense of being "exclusive accounts of the nature of reality" (Kurtz 1995, p. 238). Instead, he argued that his own community's spiritual and religious teachings were distinct from Hinduism, as imagined by supporters of Hindutva. In his writings in Hindi, he spoke of a continuity between Ravidās's teachings and those of Hinduism as a broad and diverse religious tradition. All of this then formed the basis for his political struggles for liberation for not just Dalits but all economically deprived people in India.

In order to understand the relationship between religion and politics in the life of Jagjivan Ram, it is essential to consider the particular circumstances of his religious background growing up in a Siv Nārāyaṇi family. This is because the characteristics of the Śiv Nārāyaṇī movement as a religious and social reform movement also shaped Jagjivan Ram's political career.

Seen from this perspective, his actions were both religious and political. This led him to emphasize the importance of spirituality in life as linked to economic and social development for all including the depressed classes. It also led to his patronage of the Ravidāsī community through its sacred sites, festivals, sacred literature, and places of pilgrimage, as all were central to what he saw as the foundations of religious and political life. When considering the relationship between religion and politics in India today, it is essential to acknowledge how the immense diversity of religious cultures in India has contributed to its current political life.

My conclusion is that to understand political leaders such as Jagivan Ram, it is essential to acknowledge the diversity present within Hindu traditions and explore how a nuanced approach must be taken to unpack the forms of Hinduism espoused by leaders such as Jagivan Ram. If this is not done, there is a danger that views based on Hindutva ideologies, which reject cultural diversity, may result in a negative impression of the relationship between the Hindu religion and politics in India. Perceptions 
of Jagjivan Ram as essentially a secular Dalit leader or a Hindu Dalit who supported Hindutva are both misleading. Jagjivan Ram's life and politics were shaped by his Dalit spiritual heritage and led to him becoming a champion for spiritual and political rights for all depressed classes and all Dalits.

Funding: This research received no specific external funding but was undertaken as a part of my regular research activities as an academic at the Australian National University.

Acknowledgments: I would like to express my gratitude to all the members of the Ravidāsī community and other communities who helped me learn about Ravidās and Dalit struggles for liberation and Amarjit Singh for his insights into the tradition and for introducing me to the Punjab Research Group in the UK. I would also like to express my gratitude to the late Professor Shukdeo Singh of BHU, Ramlakhan and the Sants I met at the Rajghat Ravidās temple. In addition, I would like to acknowledge my teachers including the late Krishna Mohan Singh of Harish Chandra Teaching Training College Varanasi, Ramdas Gupta, Rupert Snell and Simon Weightman of the School of Oriental and African Studies London University and Winand Callewaert of the University of Leuven. Finally, I would like to thank Jeffrey Haynes of the London Metropolitan University for his longstanding dedication to supporting scholarship on the relationship between religion and politics.

Conflicts of Interest: The author declares no conflict of interest.

\section{References}

Appleby, R. Scott. 2006. Building sustainable peace: The roles of local and transnational religious actors. Paper presented at the Conference on New Religious Pluralism in World Politics, Georgetown University, Washington, DC, USA, March 17.

Bellwinkel-Schempp, Maren. 2007. From Bhakti to Buddhism: Ravidās and Ambedkar. Economic and Political Weekly 42: 2177-83. Available online: www.jstor.org/stable/4419688 (accessed on 14 February 2020).

Beltz, Johannes. 2005. Mahar, Buddhist and Dalit: Religious Conversion and Socio-Political Emancipation. New Delhi: Manohar.

Callewaert, Winand. 1996. Śrī Guru Granth Sāhib, Vol 1. Delhi: Motilal Banarsidass.

Caturvedī, Paraśurām. 1972. Uttarī bhārat kī Sant-Paramparā. Ilāhābād: Bhartī Bhaṇạār.

Chaturvedi, Triloki Nath. 2005. 'Babu Jagjivan Ram: A Great Visionary. In Babu Jagjivan Ram in Parliament, a Commemorative Volume. Delhi: Lok Sabha Secretariat, pp. 39-58.

Dayāl, Harmohan. 2006. Varṇa vyavasthā aur kurīl vaṃś. In Upekṣit Samudayom kā ātma itihās. Edited by Badrī Nārāyaṇ, Viṣnu Mahāpatra and Anant Rām Miśrā. New Delhi: Vāṇī Prakaśan, pp. 203-84.

Grierson, George Abraham. 1918. The Siva Narayanis. The Journal of the Royal Asiatic Society of Great Britain and Ireland. pp. 114-17. Available online: https://www-jstor-org.virtual.anu.edu.au/stable/25209350 (accessed on 12 February 2020).

Jaffrelot, Christophe. 2003. India's Silent Revolution: The Rise of the Lower Castes in North India. London: C. Hurst \& Co. Publishers.

Kumar, Meira. 2005. My Father's Childhood. In Babu Jagjivan Ram in Parliament a Commemorative Volume. New Delhi: Lok Sabha Secretariat, pp. 34-38.

Kumar, Dhruv. 2013. Bihār Śatabdī Ke 100 Nāyak. Patna: Prabhāt Prakāśan.

Kurīl, Rāmcaran. 1941. Bhagvān Ravidās kī Satya Kathā. Kānpur: Kṛṣna Press.

Kurtz, Lester Ray. 1995. Gods in the Global Village. Pine Forge: Sage.

Maurya, Om Prakash. 2010. Babu Jagjivan Ram. Translated by Rupali Kishore. New Delhi: Publications Division Ministry of Information \& Broadcasting.

Mendelsohn, Oliver, and Marika Vicziany. 1998. The Untouchables. Cambridge: Cambridge University Press.

Nath, Trilok. 1987. Politics of the Depressed Classes. Delhi: Deputy Publications.

Omvedt, Gail. 2008. Seeking Begumpura: The Social Vision of Anticaste Intellectuals. New Delhi: Navayana Publishing. Pandey, Sangamlal. 1965. Existence, Devotion and Freedom: The Philosophy of Ravidāsa. Allahabad: Darshan Peeth.

Paswan, Sanjay, and Pramanshi Jaideva, eds. 2004. Jagjivan Ram: Champion of Dalits. In Encyclopaedia of Dalits in India: Leaders. Delhi: Kalpaz Publications, vol. 4, pp. 77-127.

Patel, Hitendra K. 2017. Aspects of Mobilizations of Dalits in Bihar (1913-1952). Contemporary Voice of Dalit 9: 63-72. [CrossRef]

Ram, Jagjivan. 1980. Caste Challenge in India. New Delhi: Vision Books.

Ram, Jagjivan. 1986. 1̄śvar ke aṃśdharoṃ kī asmitā ke pratīk guru ravidās. Ravidās 1: 70-74. 
Ram, Jagiivan. 2005. His Select Speeches in Parliament. In Babu Jagjivan Ram in Parliament a Commemorative Volume. New Delhi: Lok Sabha Secretariat, pp. 85-564.

Ram, Indrani Jagjivan. 2010. Milestones: A Memoir. New Delhi: Penguin.

Rāmlakhan. 1986a. Sant Ravidās aur unkā smārak. Ravidās 1: 65-69.

Rāmlakhan. 1986b. Guru Ravidās: Mandir, Kalpanā, Nirmāṇ. Vārāṇasī: Ravidās Smārak Sosaițī.

Sagar. 2019. Why the DDA May Not Have a Legitimate Claim on a Part of Tughlaqabad's Ravidās Temple Land.

The Caravan. September 28. Available online: https://caravanmagazine.in/caste/why-the-dda-may-not-havea-legitimate-claim-on-a-part-of-tughlaqabads-Ravidas-temple-land (accessed on 10 February 2020).

Saran, Sant. 2017. Bābū Jagjī̄oan Rām aur Dalit Andolan. Naī Dillī: Vāṇī Prakāśan.

Śāstri, Rāmānand, and Virendra Pāṇdey. 1956. Sant Ravidās aur Unkā Kārya. Lakhnau: Navbhārat Pres.

Savarkar, Vinayak Damodar. 1923. Essentials of Hindutva. Bombay: Veer Savarkar Prakashan.

Singh, Nau Nihal. 1977. Jagjivan Ram: Symbol of Social Change. Delhi: Sundeep Prakashan.

Tulsīdās. 1968. Śrī Rāmcaritmānas: With Hindi Text and English Translation. Gorakhpur: Gita Press.

Wilson, Horace Hayman. 1861. Siva Narayanis. In Sketch of the Religious Sects of the Hindus. London: Trubner and Company, pp. 358-59.

Zelliot, Eleanor, and Rohini Mokashi-Punekar, eds. 2005. Untouchable Saints: An Indian Phenomenon. New Delhi: Manohar.

(C) 2020 by the author. Licensee MDPI, Basel, Switzerland. This article is an open access article distributed under the terms and conditions of the Creative Commons Attribution (CC BY) license (http://creativecommons.org/licenses/by/4.0/). 
Article

\title{
Israelijew Jewisraeli: Yoram Kaniuk's Adam Resurrected and the Problem of the Human
}

\author{
Netta van Vliet \\ Cultural and Political Anthropology, College of the Atlantic, Bar Harbor, ME 04609, USA; nvanvliet@coa.edu \\ Received: 16 February 2020; Accepted: 10 March 2020; Published: 28 March 2020
}

\begin{abstract}
This article considers the political and philosophical genealogies of the category "Israeli Jew" in terms of Israeli novelist Yoram Kaniuk's Adam Resurrected, which I situate within the wider context of contemporary Israel. Israel is defined by some as a colonial and occupying state and by others as a liberal democracy founded on narratives of modern nationalism, but also on the Abrahamic narrative of 2000 years of Jewish exile. The category "Israeli Jew" thus brings together the figure of the diasporic Jew as not fully sovereign with Zionism's figure of the "New Jew," based on European modernity's ideal of a sovereign, autonomous, citizen subject. I show how, by bringing these figures together, rather than replacing one with the other, the category "Israeli Jew" brings together the specificity of the different genealogies that these terms carry. In this regard, I argue, Israel can be understood as an instantiation of the historical legacy of the philosophical binary between the Athenian and the Hebraic, which, as Miriam Leonard, Jacques Derrida, and others have pointed out, informs the long durée of Western political philosophy.
\end{abstract}

Keywords: Israel; Zionism; difference; Derrida; literature; deconstruction

\section{Introduction}

German Jewish philosopher Leo Strauss, in the preface to the English translation of his Spinoza's Critique of Religion, wrote:

The establishment of the state of Israel is the most profound modification of the Galut [the Diaspora, or Exile] ... , but it is not the end of the Galut: in the religious sense, and perhaps not only in the religious sense, the state of Israel is a part of the Galut. Finite, relative problems can be solved; infinite, absolute problems cannot be solved ... it looks as if the Jewish people were the chosen people in the sense, at least, that the Jewish problem is the most manifest symbol of the human problem as a social or political problem. (Strauss 1965, p. 6)

While Strauss and his contemporaries remarked on Zionism and Israel in terms of the challenges that Jewish difference posed for the political frameworks of European liberalism, present-day debates about Israel rarely address the question of Jewish difference. References to the political histories out of which Israel emerged draw on the principles of European Enlightenment, rather than calling them into question. Whether a pariah in the world's "family of nations" or an exceptional model to be emulated, Israel is debated, criticized, and defended within the terms of European liberalism. Critics argue that Israel should fall in line with the ideals of European liberal democracy; defenders insist that Israel already does (Pappe 2014; Shafir and Peled 2002; Yakobson and Rubinstein 2010; Yiftachel 2006). In a significant departure from the two lines of analysis that dominate the literature about Israel, this article argues neither for an understanding of Israel as the latest form of settler-colonialism, nor for an understanding of Israel as a European liberal democracy that is the latest stage of Jewish presence in the region. Rather, it shows how an analysis of the conjunction "Israeli Jew" and its political and 
material effects challenge European modernity's binaries of East and West, Jew and non-Jew, guest and host, madness and reason, and feminine and masculine on which humanism's concept of the human is founded. In so doing, an analysis of the category "Israeli Jew" reveals how what Strauss termed a human problem can be understood instead as a problem of how the human itself has been defined in the context of European modernity.

This article considers the political and philosophical genealogies of the category "Israeli Jew" in terms of Israeli novelist Yoram Kaniuk's Adam Resurrected, which I situate within the wider context of contemporary Israel. Israel is defined as a liberal democracy founded on the narrative of modern nationalism, but also on the messianic Abrahamic narrative of 2000 years of Jewish exile. The category "Israeli Jew" thus brings together the figure of the diasporic Jew as not fully sovereign, with Zionism's figure of the "New Jew" based on European modernity's ideal of a sovereign, autonomous, citizen subject. By bringing them together, rather than replacing one with the other, the category "Israeli Jew" brings together the specificity of the different genealogies that these terms carry. In this regard, Israel can be understood as an instantiation of the historical legacy of the philosophical binary between the Athenian and the Hebraic, which, as Leonard (2012), Derrida (1999), and others have pointed out, informs the long durée of Western political philosophy.

If the figure of the Israeli Jew makes explicit the co-existence of European and non-European-or Greek and Jew-within the production of the postcolonial masculine subject, then the reproduction of a polity defined in the name of this figure brings this genealogical line of origin as it is configured between two differently marked men into an encounter with the difference of woman. By posing a question about how to understand sexual difference, a consideration of Israeli Jewish sovereignty not only reanimates the "Jewish Question" but also-beyond Israel—calls into question notions of the liberal, universal sovereign subject. Such an analysis, I suggest, has profound implications for how we understand the consequences of European humanism's concept of the human, as well as the politics through which Europe and its colonial legacies took shape.

There has been increasing attention to the fact that there are aspects of Israeli society that do not fall neatly into binaries such as religious and secular (Boyarin 1996; Engelberg 2015), Arab and Jew (Shohat 2017), colonizer and colonized (Kalmar and Penslar 2005; Penslar 1991), and Hebrew and Arabic (Levy 2014). I build on these insights by suggesting that these are not anomalies, coincidental, or exceptions to Israel and its political framework as a Jewish liberal democracy. Rather, I argue, they are at the core of what defines Zionism and Israeli society. Arab Jews or Mizrahim, the overlap between "secular" and religious," and the "soldiers who shoot and cry," along with a multitude of other compositions of what are otherwise understood as binary oppositions, contradictions, or hypocrisy, are all products of the same histories that bring "Jewish singularity" and "European universalism" into the single figure of the Israeli Jew (see also Bartal 2010).

There is a growing clamor, both in formal academic publications as well as in the halls and panels of academic conferences and online spaces, for Israel to be boycotted or otherwise sanctioned for violating the principles of liberal democracy. For example, Gianni Vattimo and Michael Marder, editors of the recent Deconstructing Zionism, describe Israel as "a state that, to this day, re-founds and legitimizes itself based on a mix of millennia-old theodicy and a frozen mold of nineteenth century European-type nationalism, which has not survived in this form anywhere in Europe" (Vattimo and Marder 2014, p. $\mathrm{xv}$ ), as if European countries have advanced beyond the problems of how to address difference within the context of liberal democracy out of which Israel itself emerged, and that Israel needs to catch up to its European counterparts. ${ }^{1}$ Similarly, calls for boycotts or divestment through analogies with South African apartheid (Butler 2012; Palumbo-Liu 2015) and those who defend Israel against such calls (Nelson and Brahm 2014) elide the differences between Israel's political framework and South Africa's apartheid regime. Whereas in apartheid South Africa, it would have been impossible to have a

1 The framework of their edited volume suggests a significant misreading of deconstruction (see van Vliet 2016). 
black judge sentencing a white anti-apartheid activist to community service for actions in solidarity with black anti-apartheid activists, in Israel, it is possible to have a Palestinian judge sentencing a Jewish-Israeli activist for acts of anti-occupation solidarity with Palestinians. My point here is not that such differences signify that there is justice for or equal treatment of Jews and non-Jews within Israeli society, juridically or otherwise. There is not. Nor is it to suggest a hierarchy of suffering or of oppression. Rather, my point is that apparent contradictions in Israel reveal not a failure to abide by liberal democratic principles but, rather, the failure of liberal democracy to address the question of difference. The rest of this essay is dedicated to explaining what I mean in making this claim.

\section{Israeli Jew: Israel and the Jewish Question Revisited}

The "Jewish Question" was defined in turn-of-the-century Europe as a question about the degree and manner to which Jewish difference was or was not compatible with the ideals of European modernity (Librett 2014), as well as with political projects that took shape with and against its geopolitical contexts (Bauer [1843] 2000; Marx [1844] 2012; Peled 1992). What defined "Jewish difference" was part of this question. Questions about whether the Jew is defined by anti-Semitism; whether the Jew is a cultural, religious, ethnic, racial, or biological identity; and whether the Jew can assimilate or not were debated by Jews and non-Jews, within and outside the Zionist movement, within and outside Haskala, and in fin-de-siecle European scientific and medical discourse (Feiner 2002; Boyarin 1997; Gilman 1991; Idelson-Shein 2014). These questions overlapped with broader discussions about race, degeneration, sexuality, aesthetics, morality, economy, and Enlightenment ideals of freedom, sovereignty, and equality. As Miriam Leonard writes, "Throughout the nineteenth century and across the whole of Europe, the issue of the treatment of the Jews was inextricably bound up, on the one hand, with the project of social and political reform, and, on the other, with the attempts to define the integrity of the nation-state" (Leonard 2012, p. 7). These attempts culminated in the expulsion and mass killing of Europe's Jewish populations and then in the efforts of Europe and its allies to reassemble in the aftermath of the war.

Zionism, in the views of its most prominent leaders, was a response to the sense that Jewish difference was inassimilable in the context of European liberal democracies. As Conforti (2006) has pointed out, this did not mean that Zionists were unified or otherwise in agreement, contrary to post-Zionist polemics about Zionist history. How Jewish difference was understood in relation to European Enlightenment's universalist ideals informed the views not only of those at the heart of the Zionist movement, but also of thinkers such as Martin Buber, Franz Rosenzweig, Gershom Scholem, Emmanuel Levinas, Walter Benjamin, Hermann Cohen, Hannah Arendt, Leo Strauss, and Sigmund Freud. Their pronouncements and sometimes painful ambivalences regarding Zionism and Israel were part of wider philosophical and political debates of twentieth-century Europe, which at the time of Israel's establishment, was reeling from two world wars, the breakup of Empires, anti-colonial struggles in its colonies, and hopes and disillusionments born, in part, of the French Revolution more than a century earlier.

The establishment of the state of Israel in 1948 thus happened in the context of international tensions that were part of the political disorder of Europe and its colonies in the aftermath of WWII. When the war ended on 8 May 1945, Europe was faced with multiple challenges: how to deal with war refugees and displaced populations and how to address the questions of responsibility for the war's atrocities. As the British in Palestine sought to limit Jewish immigration, tension between the British and the Jews in Palestine intensified (Smith 2007). What came to constitute "Israeli" was thus specific not only to the situations of Jews in different national contexts but was also specific to transnational contexts shaped by Europe's relations to its colonies and to its internal others and by the Cold War. Jews thus arrived to Palestine and then Israel for very different reasons, with different cultural and political backgrounds and investments. In this context, Israel was explicitly marked as a Jewish country and refuge for Jews and as a liberal democracy and member of the world's "family of nations." However, precisely because of the diverse histories of Jewish difference and the Jew's position in relation to the 
category of modern secular citizenship, the establishment of Israel as a Jewish liberal democracy has continued to pose the question of what defines Jewish difference.

Theodor Herzl famously referred to Zionism as a dream about the creation of a Jewish homeland, both in his fictional depiction of Zionist settlement in Old New Land and in his call to action in The Jewish State. ${ }^{2}$ The establishment of the State of Israel is commonly understood within Zionism as the realization of that dream. This dream of another place for the Jew also carried with it a dream of another kind of Jew. This Jew would be a new Jew, or what leading Zionist Max Nordau called "the new muscle Jew" with a place of their own rather than wandering from place to place, with a new language taken from the old-a language of their own. The "New Jew" would be a Jew with a new character; the New Jew would shed the characteristics of the diasporic Jew and be strong, in touch with the land and physical labor, tanned by the sun rather than pale from staying indoors studying the Torah, carefree and independent rather than anxious and melancholic (Abramson 2011; Mosse 1992; Nordau 1897). ${ }^{3}$ As (Abramson 2011) has importantly pointed out, Zionism's "New Jew" went through different incarnations and was shaped by diverse influences in addition to Nordau's famous "muscle Jew," including Martin Buber's "Renaissance" Jew, Michah Yosef Berdyczewski's Nietzschean "New Man," and Herzl's "authentic Jew." As Sander Gilman (1993a, 1993b) and others have pointed out (Boyarin and Boyarin 1997; Pellegrini 1997; Rolnik 2013; Slavet 2009; Yerushalmi 1993), Zionism can also be understood in tandem with psychoanalysis as a different but overlapping response to the pathologization of what was commonly understood as "degeneration" and nervous disorders of melancholia and hysteria within the context of European modernity. Indeed, Zionism's emergence as a response to anti-Semitic exclusion from European modernity's universalist ideals took shape in overlapping political and intellectual conditions with psychoanalysis. ${ }^{4}$ In this sense then, in ways both similar to and different from psychoanalysis, Zionism sought to remake Jewish difference in the terms of self-possession, sovereignty, and autonomy. However, it did so precisely in the name of defending the Jew as not self-possessed or sovereign. The figure of the (new) Israeli Jew is thus haunted and undone by the diverse histories of the diasporic Jew.

The category "Israel Jew" therefore also draws attention to the implications of how Jewish difference is defined for the definition of the modern, liberal secular citizen subject of European modernity. By simultaneously declaring itself to be Jewish and not only a liberal democracy, Israel continually poses challenges to the assumptions of the possibility of the metalanguage presumed by the law and grounded in European modernity's political frameworks of a liberal humanism, or in Dipesh Chakrabarty's terms, "the concept of the universal and abstract human who bears" the Enlightenment themes of juridical freedom (Chakrabarty 2000, p. 50). To ask how the proper name "Israel" is haunted by the proper name "Jew," or how the category of the universal and abstract citizen is haunted by the Jew, requires placing the narratives of Jewish exile and return in the context of WWII and its aftermath and in the context of European nation-state formation. ${ }^{5}$ I now turn to consider what might be learned from an analysis of the category "Israeli Jew" in these terms, through a reading of Israeli novelist Yoram Kaniuk's Adam Resurrected (Kaniuk [1969] 1971).

\footnotetext{
See (Herzl [1902] 2009) and (Herzl [1896] 2018).

See Almog (2000) for a vivid fictional account of the ideal of the Sabra.

For discussions of the historical overlap between Freud and Herzl, see Loewenberg and Stone (1970); Avner (1996).

"Jew" in this sense suggests that a proper name can never be autonomous or owned by only one (in the sense of being singular plural, see (Nancy [1996] 2000), which then presents the question of what kind of "ownership" this would be. In his rereading of the story of Babel, Derrida suggests that the text of the story can be understood as conveying a double injunction from God: "translate me, translate my name," and "don't translate me, don't translate my name, you won't be able to" (Derrida 1985, p. 77). Derrida suggests that such a double command, or in his word, "desire," is at work in every proper name.
} 


\section{Israelijew Jewisraeli: Greekjew Jewgreek and Yoram Kaniuk's Adam Resurrected}

Kaniuk's novel Adam Resurrected, first published in Hebrew in 1969 (with the title Adam Ben Kelev), tells the story of Adam Stein, a Holocaust survivor who was a clown and violinist by profession, who survives the concentration camps by clowning under the gaze of his Nazi commanders in front of the lines of camp inmates as they walk to their deaths in the gas chambers and by living as a dog with the four legged canine Rex in the apartment of his Nazi commander Herr Klein and his wife. ${ }^{6}$ After the war, Stein goes to Israel, where, after he attempts to kill his German Jewish landlady with whom he is involved in an amorous relation, he is taken to an insane asylum for the rehabilitation of Holocaust survivors.

Throughout the book, Adam is visited by his twin brother, Herbert, who appears as a ghostly presence on Adam's windowsill in his room in the asylum. When Herbert is first introduced in the book, it is soon after Adam is brought back to the asylum after trying to strangle his German landlady in Tel Aviv. Soon after Adam arrives back in the asylum, he is visited by his twin,

who was a philosophy student in Heidelberg and studies under Professor Maritain and under old man Ludwig, the author of The Lucky columns, somebody who will never acknowledge the bitter truth that Adam Stein, his twin, was a circus clown who became the lowest of the low, namely, 'the Jew who made Klein laugh,' the Jew who performed there, twisted his nose and prestidigitated, and all this in front of his proud wife, Gretchen. (Kaniuk [1969] 1971, p. 59)

\section{Adam says,}

'But Herbert, my brother, we remained alive on account of my clowning and not on account of your being a famous Hegelian ... ' Adam is tense, his body one taut bow; soon he will hear the keys in Shapiro's hands clank and the door slam, soon the swish of the lock and the background music in the hallway will vanish and just the two of them will be left, he and Herbert, and then he can die. Meanwhile Herbert is still on the windowsill, as the white of the Dead Sea flickers in the distance and signals crooked images with its rays.

Herbert then replies, "Adam Stein, you amaze me. You're miserable, very miserable. And to think we two are caught in one body. It's weird, really weird. And sad. Above all, sad."

Adam clenches his fist. How ridiculous he is, this perpetual student sitting on the windowsill. 'Get down from the window, you beast of prey. You're driving me crazy.'

'Me?' Herbert bursts into such laughter that it shakes the mountains of Judah, the desert, the ancient Dead Sea, the salt flats, Lot's wife, the Essenes, Elijah. 'That makes two of us. If you're crazy, so am I.' (Ibid.)

The figure of Adam Stein is haunted by his Jewishness in the form of his twin brother Herbert, the secular, modern philosopher German Jew, and in the form of his former self as a Jew who survived the Holocaust by living as a dog. As an Israeli Jew, he is caught between the modern citizen subject modeled on the figure of the Greek and the Jewish Abrahamic subject, based on the narrative of 2000

6 My discussion here focuses on the English translation of Kaniuk's novel. The Hebrew title, Adam Ben Kelev, translated literally, is "Adam Son of a Dog." In this essay, I do not focus on the Israeli political events of the 1960s that shaped the context within which Kaniuk was writing. For considerations of Kaniuk's work in terms of the 1960s Israeli political contexts and literary canons of which it is part see Hess (2016); Shaked and Peleg (1996).

It should also be noted that there is a 2008 film based on the novel, with the same title, "Adam Resurrected," directed by Paul Schrader, with Jeff Goldblum cast as Adam. While the film version is able to convey the theatricality and absurdity of many aspects of the novel in ways that perhaps surpass the novel itself, the film is unable to present the ambivalence of how $\mathrm{dog} /$ human boundaries are confounded in the same way as the book, as in the film, the viewer sees either a dog or a human acting like a dog. More significantly in terms of my discussion of the novel here, the film does not elaborate on Adam's subjectivity through his relation to his twin brother Herbert; the dialogues with him in the novel are absent in the film. 
years of exile and return. It is precisely because the Jew could not survive in Europe in the form of his brother Herbert that Jew is redefined as both Jew and Israeli; he is both the Jew of the Abrahamic narrative of exile and return and the citizen based on the Greek narrative of metaphysics. In this sense, Stein brings together the different genealogies attached to these narratives and their binary oppositions of reason and madness, inside and outside, and secular and religious. He can thus be understood to contain a relation between two different men, Jew and "non-Jew," or Jew and Greek, within the genealogy of European modernity.

As Leonard (2012) has pointed out, the concept of the Jew as outside of the framework of the modern nation-state was prominent not only in existentialist and postwar thought, but also was an explicit element of European Enlightenment thinking and particularly of German philosophy. Hegel, she writes,

reveals how the Jews do not actually own their land, they have it merely as a loan from their God. As such, they have no concept of family property. 'The Greek process founds rights and politics, constitutes family subjects as citizens. The Jewish process, on the contrary, scoffs at rights and politics.' The Jews are stuck in the same double bind that has marred their existence since Noah. They are incapable of being citizens because they are incapable of being a family, incapable of being a family because they lack the political rights of the citizen. In the end, for Hegel, the Jews cannot be citizens because they are not Greeks. (Ibid., p. 91)

By tracing what she calls "the persistent figural 'work' done by the Greek/Jew couplet in giving form to a range of Enlightenment and post-Enlightenment philosophical, social, and political concerns" (Ibid., p.12), Leonard offers an account of how the figure of the Jew has shaped the history of ideas through which European modernity and post-Enlightenment political frameworks have come into being. In so doing, she provides an analysis of the historical philosophical foundations through which an opposition between Athens and Jerusalem has been a powerful signifier in European thought and shows how "the Greek/Jew opposition is an exemplary case, if ever one was needed, of how symbolic structures come to have consequences in the 'real' world" (Ibid.). In the literary imagination, this opposition appears most famously in the work of James Joyce in Ulysses. Joyce himself was informed, as Davison (1998) has traced, by different engagements with the notion of the Hellenic Hebraic relation in Culture and Anarchy (Arnold [1869] 2009) and in Nietzsche's philosophical writings.

This internal difference between Greek and Jew within a single subject is produced in the context of Israel through the establishment of a polity in the name of this figure. The category "Israeli Jew," by bringing together the philosophical coupling of Greek and Jew within a single figure, places the figure of the Jew simultaneously in the position of host and of guest. This relation in which the Jew is both guest and host to another within a single subject, can also be understood in terms of the position of Jew as guest on the scale of the nation-state, and in relation to God, in the narrative of modern nationalism and in the messianic narrative of exile and return.

Historically, the figure of the Jew has been understood as that of guest both in terms of genealogies of modern nationalism and in terms of Biblical narratives. In terms of the former, the figure of the Jew is situated as guest by definition, as thinkers as different as Jean-Paul Sartre, Theodor Herzl, Sigmund Freud, Hannah Arendt, Max Nordau, and Jacques Derrida have all suggested, albeit in significantly different ways and with different implications. What makes a Jew a Jew in relation to European nationalisms, they differently suggest, is tied to a genealogical narrative that defines the figure of the Jew as always in excess of and before and beyond the nation-state, originating from elsewhere and destined for elsewhere. Thus, even the most assimilated Jew, if there is any remainder of Jew left, remains defined as guest in relation to the nation-state. In terms of the Biblical narrative, as Lévinas (1994) and Derrida (1999) have both differently emphasized, the Old Testament introduces the Jew as a guest of God, both in relation to language and land; the Jewish people are guests of the Hebrew language and guests in the land promised to them by God. The narrative of more than 2000 years of exile thus situates the Jew as guest both in terms of the Biblical narrative of exile from an 
original homeland where they were guests of God and in terms of the Jew's relation to the modern nation-state form.

It is precisely because Israel is based on the model of European liberal democracy and simultaneously defines itself as Jewish in terms of the messianic narrative of exile and return that the conjunction Israeli-Jew can be understood as making explicit the Greek/Jew opposition, in which the Jew is simultaneously in the position of host and of guest vis-à-vis the nation-state. By bringing together the categories "Israeli" and "Jew," without subsuming one within the other, the establishment of Israel as a Jewish liberal democracy has positioned the figure of the Israeli Jew as simultaneously host and guest. When Jew becomes joined with Israeli through the establishment of a Jewish liberal democracy, Israel Jew thus becomes host, while remaining also guest, within a single subject position.

Adam Stein condenses Greek and Jew in a single subjectivity in a way that echoes the politics of contemporary Israeli Jewish national identifications and state policy. He represents the man of reason and of madness, the animality of Jewish difference and the non-Jewish human mastery of the animal, God and the (Jewish) man named by God, the German and the Jew, the Greek and the Jew, the universal and the particular, violence and pleasure, the Kantian philosopher (in the specter of his "twin brother") and the Jew ridiculed by and excluded from this philosophy, the citizen and the non-citizen, the masculine and the castrated, circumcised, and emasculated, but importantly, not the feminine.

\section{Israeli Jew, Host and Guest, Sexual Difference}

How are we to understand how the relation of the Jew and non-Jew, or the co-existence of Herbert and Adam "in a single body," within a single subject in relation to the figure of woman, through whom the collective people in the name of this single subject-Herbert Adam or Israeli Jew-is reproduced as a group? It is through an attention to this question of reproduction that Khanna (2014b) brings James Joyce's Ulysses and the Greekjew coupling it references to bear on a consideration of Kaniuk's novel. In her discussion of Zionism in terms of the concept and practice of asylum, she reads Adam Stein through the figure of Leopold Bloom in Joyce's Ulysses and the figurative relation between Greek and Jew in geographical terms, which she connects to a discussion of sexual difference.

Drawing on Miriam Leonard's consideration of the relation between Hebraism and Hellenism, Khanna situates Stein in terms of this relation, which "is set up from Roman times to the present between the Greek and the Jew from Tertullian to James Joyce: between Hellenism and Hebraism, Christianity and paganism, rationality and irrationality, secularism and religion" (Khanna 2014b, p. 137). She suggests that this coupling can be understood in terms of a geographical binary, which "points towards a quintessential difference, one could say: the sexual difference. The oft-quoted line from James Joyce's Ulysses highlights the blind spot to difference as encapsulated within sexual difference-'Women's reason: Jewgreek is Greekjew. Extremes meet'” (Ibid.). She goes on to suggest that while Miriam Leonard rightly understands this as referring to an idea of women's irrationality, it can also be understood as opening

to a form of a yet to be realized feminine difference that became so important for Derrida ... which plays indeed also with the sense of internal exile from a site of belonging ... we could understand this autobiographically as being a Jew in Oran, Algeria during the moment of the abrogation of French citizenship of Jews during the Vichy regime. (Ibid.)

Khanna defines this feminine difference here in terms of a geographical binary between Athens and Jerusalem, as a difference that is suppressed in a political framework based on belonging that does not acknowledge internal exile-those who are "exiles unto themselves, contained within a shared space" (Ibid.). In this sense, postcolonial difference is understood in terms of the internal exile produced by the erasure of a relation to origin through which feminist theory has defined sexual difference. As Elizabeth Grosz has put it, drawing on Luce Irigaray (1987), 
the containment of women within a dwelling that they did not build, nor was even built for them, can only amount to a homelessness within the very home itself: it becomes the space of duty, of endless and infinitely repeatable chores ... the space of the affirmation and replenishment of others at the expense and erasure of the self. (Grosz 1995, p. 122)

Considering Israel in terms of asylum and the internal exile of postcolonial difference is thus to follow through with Khanna's argument elsewhere that one must reconsider Irigaray's discussion of the speculum that brings the question of origin and womb back into Western philosophical discourse by bringing postcolonial difference to bear on the manner in which Western metaphysics erases a relation to origin (see Khanna 2003).

Khanna shows how the "passage between" that is erased in the Platonic metaphor of the cave is a passage not only between the terms "man" and "woman," but also between the image of the ideal of the universal man and the marked postcolonial man. She writes,

[Frantz] Fanon's example of the disappearing black who is perceived as invisible first by whites and then consequently, according to Fanon, by blacks, raises a number of important issues that relate to the status of the material and the manner in which it shares in the constitution of subjectivity ... In the eyes of others, subjectivity disappears. This is, of course, different from the threat to one's own subjectivity by the imago in the mirror, because it is suggestive of the mechanisms that constitute the mirror itself. It is not something transparent, or something through which assurance of existence can be guaranteed in a familiar 'mirror' pose ... (Khanna 2003, pp. 181-82)

The mirror itself is here highlighted as not ever a universal, unmarked mechanism through which one's image is reflected. In other words, in a manner that elaborates on Irigaray's move to think about image making in terms of the concave dimensionality of a speculum rather than the flatness of a mirror, Khanna points out that the technology through which one's image is made is itself historically, economically, and biologically marked. When, "in the eyes of others, subjectivity disappears," it is through eyes that see a reinforcement of the ideal of the universal human, through which difference is objectified or made invisible. In other words, it is the non-place of the marked woman who forces a consideration of these two genealogical lines simultaneously. An analysis of the figure of the postcolonial woman thus raises the question of how the constitution of European modernity's concept of the human is defined in relation to the man marked as both inside and outside European modernity's universal human, i.e., the postcolonial or Jew. The "human problem" to which Leo Strauss refers in terms of "the Jewish problem" can thus be understood as a problem of how the human itself has been defined within European modernity. An analysis of the figure of the Israeli Jew points to how the constitution of the human leads to a question about the difference of woman in relation to the reproduction of the postcolonial.

Khanna calls attention to the fact that Kaniuk's novel does not, as she puts it, "adequately address the loss of the feminine that leads to the patrilineal parthenogenesis of dog-children" (2014b, p. 141). In the novel, Adam Stein's Israeli self that has survived from the ashes of the Holocaust can be understood as the offspring of the relation between his dog self and his Nazi commander Herr Klein. In the asylum in the Negev desert, Adam in turn "fathers" a dog-child when he "rehabilitates" a child inmate (who at first is more dog than child) from dog into child. It is, as Khanna suggests, through an attention to the specificity of the relation of hospitality between men that this loss of the feminine may be addressed. But to do so means to refrain from eliding or analogizing the internal exile of the postcolonial man and the internal exile of feminine difference. It is exactly through attending to their relation in terms of how they are distinct from one another that it is possible to address the question of what feminine difference is. This question then turns us to the question of how the human has been defined through an understanding of the difference of a people.

Bloom, and similarly but even more explicitly, Adam Stein, are understood as postcolonial men, which is to say that their internal exile is produced exactly by the condition of postcoloniality. In this 
reading, Stein is a reiteration of Leopold Bloom, who, Khanna points out, can be understood as "the quintessential wandering Jew of literary modernism" (Ibid., p. 137). It is then precisely the question of reproduction of the postcolonial polity, in this case Israel, which demands an attention to the difference between the internal exile of the postcolonial and the internal exile of the feminine. To conflate the internal exile of feminine difference with that of postcolonial difference is to leave unaddressed the relation - and importantly, the difference-between the relation of guest and host within individual subject formation, marked in terms of the difference of a people, and the relation of guest and host between peoples, marked in terms of the difference of sex within a people. We can therefore read the novel in terms of an analysis of the genealogy of the Israeli Jew that would suggest the feminine never was present and thus was not lost but, rather, served as a prosthetic support for the production of the human in terms of a difference among men.

In the novel, the feminine only exists in the form of animality, death, or violent eroticism. It is an act of erotic but potentially deadly violence against the German landlady Ruthie Edelson from whom Adam rents a room in Tel Aviv that lands him back in the Negev asylum; Ruth is also the name of his daughter who survived the war and came to Israel only to die in childbirth, and it is the name "Ruth" that, in the office of the asylum's director, Dr. Gross, is recalled under the gaze of a portrait of Sigmund Freud and that gets "stuck in his throat and wouldn't come out" (Kaniuk [1969] 1971, p. 23). Similarly, it is through overdetermined transferential relations between people haunted by the name of the dog through which Adam, at his daughter's grave without a gravestone in Israel, tries to understand what it means to be a Jew, a man, a father, a husband, a human, and a survivor. The relation between guest and host, marked as the difference of a people within the figure of the postcolonial man, thus confronts the question of the reproduction of the group in relation to the figure of woman.

There in the cemetery, at the site of his daughter's grave, his son-in-law's words "Now make her laugh. You're funny, aren't you?" (Ibid., p. 143), ordering him to make his dead daughter laugh, return Adam to the words of Herr Klein to him and to Klein's dog Rex with whom Adam shared a bowl and a master:

Adam stares at him. He can't understand, but the words ring a distant bell in his ears. Now/you/must/make/her/laugh ... Klein's command! Herr Stein, your life for your clowning ... Rex, don't bark, this man is your brother. You're a purebred and he's a mongrel. Who will win out, the pure Jew or the pure dog? The pure dog lost because the pure Jew was much more popular. Rex, the kingdom of Rexes ... (Ibid.)

Adam begins his clown routine. He makes his son-in-law laugh and then also the growing crowd of cemetery beggars who gather around them in a ring at the site of his daughter's grave. But then Adam drops to all fours to kiss the soil there where there is no tombstone, and sees the hostile looking faces of the beggars, who are making a racket shaking their tin boxes of charity.

The laughter of the beggars exposes gold teeth. And mouths that are toothless. Dark caverns. Stench and grotesquery. The beggars see that the two men are shocked, and laugh. And laugh. And laugh. Money! Money! Geld! Geld! (lbid.)

Adam's son-in-law, scared, instructs Adam to run, insisting that they leave. Adam says he cannot, that his body refuses, and thinks to himself that "it is God's doing." Wanting to laugh he "recalls Rex. Rex was, Rex is, Rex will always be. You will come from dust and to dust you will always return. Good old dust. They both stink. The usual odor. Soon they will be smoke. Smoke has no color, just odor" (Ibid., p. 144). They then leave, Adam following Joseph, crawling on all fours after him. The beggars are no longer frightening but, rather, are frightened themselves, screaming in a panic after Joseph and Adam, who "like a boy and his dog," leave with the beggars calling after them "Demon! Bug! Monster!" (Ibid.). 
In this passage, Adam and Joseph are thus referenced simultaneously in terms of a demand for money and as animal, as monstrous ${ }^{7}$ Adam here reiterates a point he makes earlier when he references Jews in terms of soap. Soap was the denigrating term that had been used in Israel to refer to Holocaust survivors with reference to the Nazi manufacturing of soap out of the bones of the Jews they killed.

"Men are soap," Adam reflected,

they hold people in their hands, clean innocent sterilized people. Oh, that sterilization. Those cultivated rules of the game. Oh the latent terror of the fact that today you can say $I$ scrubbed him good, meaning I finished him off. And any paleface who looks like a refugee is a piece of soap. And soap has no body or muscles. Soap is what they made out of us ... He was soap personified and saponified, ambling through the markets in order not to have to face Ruth. The former Ruth Stein who was turned into a pillar of soap but escaped and became a golden crucifix. That's fate. The sign of circumcision she can erase with a knife, but what about the soap? (Ibid., p. 133)

The question of Jewish difference here thus emerges in relation to the European gentile and in relation to the Jewish woman who is present only in the form of an unmarked grave or, elsewhere in the book, in terms of a sexed figure who veers between victim of violence and sexual animality, her presence marked by death or absence. This violence is itself positioned in relation to the tension and conflict between two figures of men-Jew and non-Jew-and between man and animal.

The category "Israeli Jew," and I would suggest, the postcolonial generally, raises a question about how to understand the difference of woman precisely because the postcolonial, or here specifically the Israeli Jew, brings together two different lineages through which a single figure is reproduced-Greek and Jew or European and non-European. The difference of reproduction here is thus signified through the difference of a people rather than as the sexual difference within a people. The reproduction of this figure thus places the two lineages within the postcolonial in relation to the figure of woman. I will go on to suggest that an analysis of the definition of sexual difference in these terms reveals that the definition of the human, within European humanism, relies on the production of the difference of a people being concealed by the definition of sexual difference as the difference of the reproduction of the human. Reason, self-possession, and sovereignty then define the human rather than a subject who is simultaneously guest and host, constituted through a difference that undoes any claim to full self-representation and thus a subject unable to be in self-possession or to be sovereign in the terms of European modernity.

To attend to the specificity of the GreekJew coupling is to trace the question of Jewish difference back to the narrative of asylum in terms of a relation to God and to return to European modernity by way of what was prior to it, in terms of not only the Jew but also its many polytheistic others. In other words, the internal exile of the Greekjew, or of the postcolonial, is constitutively and substantively different from the internal exile of the feminine and the figure of woman. By making explicit the question of reproduction of a subject produced in a relation between differently marked "men" (be they Jew and non-Jew or God and man), understanding Israel through a consideration of asylum makes explicit the need for rethinking the human itself.

\section{Conclusion: Israeli Jew, Asylum, and the Question of the Human}

Kaniuk's novel, like Israel itself, brings together the narrative of origin of the Jewish Abrahamic covenant with God, together with the narrative of modern nationalism and the sense of an abandonment

7 Geld is the word in German for money, but it also refers to a castrated male animal. Given the context of this scene then, the choice to use this word in the English translation gives additional emphasis to the way in which the passage challenges the distinction between man and animal and also invokes an emasculated man. The Hebrew word for money, kesef (ఇסכ), and the Hebrew word for "yearning," kissufim (כיסופים), share the same root. I do not know if Kaniuk weighed in on the choice to use the word geld in the English, but it makes for an interesting translation. 
by God "in the most advanced factory of Europe." In the novel, the refuge promised by God is returned to through the creation of a mental asylum within, but also in excess of, the asylum of the state Israel. Israel shows how asylum is not the negation of diaspora or of nation-state modernity but, rather, confounds the terms of negation by revealing what is remaindered by the categories of diaspora and nation-state modernity. In other words, to think about Israel in terms of asylum is to understand the postcolonial anachronistically as the territorialization of Greeks and Jews in a single polity, as well as within a single subject. 8

Israel is defined both in terms of a liberal democracy and in terms of a Jewish country and thus combines two interrelated logics into one figure by creating the category "Israeli Jew." By two inter-related logics, I refer to what Derrida has described in terms of a Greek logic based on a metaphysics of presence and a Jewish and Abrahamic logic based in a tradition of relation to the text. In the latter, the Jew is situated as a guest to its own existence, a guest to its language and its land through its relation to God via the text-who is both host and who demands of the Jews that they "host" him. This is the distinction that Derrida points out when he critiques Levinas for reinstituting a metaphysics of presence by placing a relation to alterity in terms of a dimension of height through a relation to the presence of God or the Divine. To do so, Derrida suggests, is to place difference in the plane of the ontological where it can be anticipated rather than opening the ontological to an other through which existence as presence cannot be fully present to itself. Such an opening is a form of hospitality that Derrida connects to the impossibility of forgiveness.

The scene in Kaniuk's novel in which Adam Stein moves between laughter and tears at his daughter's unmarked grave in Israel, returns us to Derrida's opening in his essay on "hostipitality." Derrida begins:

We have not yet encountered this strange possibility, regarding hospitality, the possibility of laughter ... We have often spoken of mourning, of hospitality as mourning, of burial, of Oedipus and Don Juan, and recently even about the work of mourning as a process of hospitality, and so on.

But we have not evoked laughter. Yet it is difficult to dissociate a culture of hospitality from a culture of laughter or a culture of smile... This is part of its essence in a way, even if the smile is interior and discreet, and even if it is mixed with tears ... (2002, p. 358)

Derrida goes on to ask what one should await from laughter, what one should expect of it. ${ }^{9}$ Saying that we know nothing of this, he goes on to remind us that we do know enough however to tell ourselves that

hospitality, what belabors and concerns hospitality at its core [ce qui travaille l'hospitalite en son sein], what works it like a labor, like a pregnancy, like a promise as much as like a threat ... is indeed a contradictory conception, a thwarted [contrariee] conception, or a contraception of awaiting, a contradiction of welcoming itself. And something that binds perhaps, as in Isaac's pregnancy [la grossesse d'Isaac], the laughter at pregnancy, at the announce of childbirth. Abraham, of whom we will speak a lot today, laughs, like Sarah, at the announce of Isaac's birth (Yishaq means 'he laughs'). (Ibid., pp. 359-60)

Derrida elaborates on this contradiction at the heart of hospitality, which he connects to forgiveness, because to welcome the other, to be open and hospitable to the other without knowing what he, she, or it is in advance, is also to forgive this other of "whatever his fault or his indignity, whatever the offense

This could also be understood then as a figure and a place of "hostipitality" (Derrida 2002, p. 358).

9 Derrida here references both Abraham's laughter and Sarah's laughter. While it might be argued that Sarah's laughter is cathartic or laughter filled with delight in response to the news that she will bear a child, her laughter has also been read as bitter, derisive, and skeptical. Why she laughs (and why she denies having laughed) is left open and uncertain, as others have noted (see Gift 2012; Henz-Piazza 2004). 
or even the threat," to forgive but also to ask for forgiveness for being structurally lacking and at fault for being unable, by definition, to ever give enough to or to expect enough the welcomed unexpected visitor or arriving one and thereby being positioned "so as to abandon the other, so as not to give him enough, and thus to leave him abandoned" (Ibid., p. 381). This brings Derrida to a notion of the messianic without messianism or messiah and to Jewishness through the impossibility of forgiveness.

Derrida recalls here the joke of two Jews, longtime enemies, who meet at a synagogue on Yom Kippur, the Jewish day of Atonement. One Jew says to the other, "I wish for you what you wish for me." The other one retorts, "Already you are starting again?" (Ibid.). There is no forgiveness without memory, but also forgiveness is not reducible to memory, Derrida writes. "A story for laughs," but what, Derrida goes on to ask, "makes us laugh, laugh or cry, and laugh through the tears or anguish?" (Ibid., p. 382). He goes on to point out that, in this moment of laughter between the two Jews who make the gesture of forgiving, who fake it, they persist with the conflict, making legible the impossibility of forgiveness, but also that, in enduring together this impossibility, a kind of compassion is possible, both in being unable to ask and in being unable to grant forgiveness. Returning to Israel, we can follow this question of hospitality and abandonment in terms of the Jewish narrative of a relation to God, exile, and the promise of refuge and thus also of selection by God.

In Kaniuk's novel, the asylum in the Negev is both a return to the place of refuge promised by God to his people and the result of his abandonment of his people, his failure to grant them refuge, hospitality. The refuge promised and failed by the nation-state is layered on top of the refuge promised and failed by God, and these two failures come together in the madness of the mental asylum and the struggle between the ideal of the rational human subject and the mad, unreasonable, Jewish survivor of the camps, not fully human. "The guilt of the survivor," Derrida writes,

... is not only that of the concentration camp survivor, but, first of all, of any survivor, of anyone who is mourning, of all the work of mourning-and the work of mourning is always an 'I survive,' and is therefore of the living in general-regarding the originary guilt of the living as survivor who must therefore be forgiven simply for the fact of living and of surviving the death of the other ... (Ibid., p. 383)

Derrida here calls attention to the displacement through which the self-deconstruction of hospitality is hidden through a logic of substitution there where no substitution is possible, where the subject is irreplaceable. It is here where Derrida demands an attention the presence of the third, of the other of the other that enters into the relation of the face to face, a specter without ontological or concrete predicates or what Derrida calls a silence at the heart of the call of the other. It is a silence, or an illegibility, that comes from the abyss of the relation between ethics and politics, ethics and law-a silence that demands a decision be taken without full knowledge. To be hospitable is "to let oneself be overtaken [surprendre], to be ready to not be ready, if such is possible, to let oneself be overtaken, to not even let oneself be overtaken, to be surprised, in a fashion almost violent ... " (Ibid., p. 361). This process of substitution and hospitality is also part of the archival logic of fraternity on which Western democratic traditions have been based.

Derrida, in drawing attention to the relation between hospitality and hostility in terms of an ethical relation to the other, raises the question of what it would mean for the figure of woman, and thus of sexual difference, to enter into this relation of substitution. It is worth quoting here at some length from Derrida's essay, "A Word of Welcome," written in memory of Levinas after his death. Derrida writes:

In the final pages of Totality and Infinity, we find the same themes of hospitable peace and uprooted wandering. Bypassing the political in the usual sense of the term, the same logic opens a wholly other space: before, beyond, outside the State. But one must wonder why it now centers this 'situation,' no longer on the femininity of welcoming, but on paternal fecundity, on what Levinas calls, and this would be another large question, yet another marvel, the 'marvel of the family.' This marvel concretizes 'the infinite time of fecundity' -a 
non-biological fecundity, of course - 'the instant of eroticism and the infinity of paternity.' (1999, p. 93)

Derrida remarks that here Levinas replaces the figure of woman as host with the paternal figure of the Divine as host. The figure of the third for Levinas then becomes signified in terms of the relation between oneself, another, and God, in which the figure of woman as ground is displaced by the figure of God as that which hosts and gives ground to man. For Levinas, this host and the election of the guest are tied to the narrative of the Old Testament.

Levinas presents a philosophy of ethics of relation to the other based on a relation to alterity. But Derrida points out that the manner in which Levinas bases his understanding of a relation to alterity in terms of a relation to the divine in the figure of God ultimately reinstitutes a metaphysics of being by placing the presence of God in the plane of being rather than placing being in a relation with the unknown other of alterity. In "A Word of Welcome," Derrida (1999) addresses this move in terms of the relation between Levinas's philosophy of an ethics of relation to the other and his political positions on Zionism and Israel and in terms of the question of sexual difference.

The presence of the third, of the other of the other that enters into the relation of the face to face, a specter without ontological or concrete predicates, presents what Derrida calls a silence at the heart of the call of the other. It is a silence, or an illegibility, that comes from the abyss of the relation between ethics and politics, ethics and law - a silence that demands that a decision be taken without full knowledge. Derrida writes that he hears such a silence in Lévinas' conclusion that speaks of a hope beyond refuge. Lévinas writes:

What is promised in Jerusalem ... is a humanity of the Torah. It will have been able to surmount the deep contradictions of the cities of refuge: a new humanity that is better than a Temple. Our text, which began with the cities of refuge, reminds us or teaches us that the longing for Zion, that Zionism, is not one more nationalism or particularism; nor is it a simple search for a place of refuge. It is the hope of a science of society, and of a society, which are wholly human. And this hope is to be found in Jerusalem, in the earthly Jerusalem, and not outside all places, in pious thoughts. (1994, p. 52)

Derrida suggests that there is a silence at the heart of this call, which highlights the exposure of the law to itself, as non-law, in the moment in which law becomes both host and hostage, "when the law of the unique must give itself over to substitution and to the law of generality ... when the "Thou shall not kill' ... still allows any State ... to feel justified in raising an army, in making war or keeping law and order, in controlling its borders-in killing" (Derrida 1999, p. 116). This openness, or silence, at the heart of the call and speech of the other, is what conditions and marks the beginning of responsibility; it marks the moment of indecision, the discontinuity between what Derrida calls "the messianic promise [unconditional hospitality] and the determination of a rule, norm, or political law" (Ibid., p. 117). He continues:

This discontinuity, moreover, allows us to subscribe to everything Levinas says about peace or messianic hospitality, about the beyond of the political in the political, without necessarily sharing all the 'opinions' in his discourse having to do with an intrapolitical analysis of real situations or of what is actually going on today with the earthly Jerusalem, or indeed with a Zionism that would no longer be just one more nationalism ... (Ibid. pp. 117-18)

To be responsible to Levinas, Derrida suggests, is to respond to this contradiction, to the places in the text that interrupt themselves. The "earthly reality" of contemporary Israel, by bringing together two different fraternal narratives, thus creates a situation in which these narratives encounter and contest one another. An analysis of the political claims made in the name of the category "Israeli Jew" might, as Khanna puts it in her work on psychoanalysis, allow us "to understand how the idea of being is attached in the modern period to both self-possession and material possession; as critics of 
international law remind us, belonging becomes linked to land through property" (Khanna 2014a, see also Khanna 2007).

Israel has been framed as a place intended to provide unconditional hospitality and welcome to all and any Jews, but also as a liberal democracy, with the values of citizenship, freedom, equality, and universal human rights that liberal democracy carries with it. It is defined, therefore, both as explicitly singular —as a Jewish state that was officially established in the aftermath of WWII-and as generalizable in its particularity as one of many liberal democracies. The figure of the Jew then also becomes generalizable, highlighting the contradictions of liberal democracy's inability to guarantee universal and unconditional hospitality, as Leo Strauss, and differently Hannah Arendt, famously pointed out. However, Israel also thereby reproduces those contradictions within the framework of a Jewish state, bringing into question the concept of the human in relation to which the Israeli Jew is defined.

Adam Resurrected ends with Adam narrating in a letter to his son-in-law Joseph that Herbert died and that he, Adam, survives as his living tombstone. The dog-child recovers and leaves the institute a young man. Adam is understood to have recovered, though he himself is uncertain, and he returns to live with the landlady Ruthie in Tel Aviv. Adam tells Joseph goodbye and good luck and ends with "may all dogs talk to one another" (Kaniuk [1969] 1971, p. 370). Khanna, in reference to the novel and a discussion of Israel, suggests that we think in planetary terms, highlighting that "the figure coming into the mental asylum or seeking political asylum becomes human though a process of becoming subject-forced into a recognizable form as if the inhuman state of being before those laws, and indeed after them, could be erased" (Khanna 2014b, p. 144).

It is through such erasure that the notion of the human is sustained and reinforced, through the violent elision of the difference internal to a people and the difference between a people. Women and men, marked as different in religious, ethnic, racialized, or national terms, both sustain and threaten the boundary between human and animal produced through this elision. Humanism's response to the threat such subjects pose is to base politics on terms of equivalence-citizen, human, community-in which difference is understood as the distinction between subjects rather than as the internal difference of the foreign that undoes claims to subjectivity from within. An analysis of the category "Israeli Jew" thus reveals the violence of discourses based on identity politics, belonging, and community, whether these discourses are under the sign of revolutionary struggle, suicide bombings, state terror, liberalism, or various forms of nationalism. Difference as that which is not fully inside the polity nor fully outside then becomes a threat. For Derrida, difference is the unknown, the foreign, before it has been identified as inside or outside, friend or enemy, human, animal, or divine. Difference is the circumcision through which subjectivity is simultaneously made possible and undone. An analysis of Israel in these terms can thus turn us back to the hope for the possibility of a democracy to come, based not on an Aristotelian political subject but on an openness to the foreign that undoes the human itself.

Funding: This research received no external funding.

Conflicts of Interest: The author declares no conflict of interest.

\section{References}

Abramson, Glenda. 2011. 'The first of those who return': Incarnations of the New Jew in modern Hebrew literature. The Journal of Israeli History 30: 45-63. [CrossRef]

Almog, Oz. 2000. The Sabra: The Creation of the New Jew. Berkeley: University of California Press.

Arnold, Mathew. 2009. Culture and Anarchy. Oxford: Oxford University Press. First published 1869.

Avner, Falk. 1996. A Psychoanalytic History of the Jews. Cransbury: Associated University Presses.

Bartal, Israel. 2010. The other story: Israeli historians and Jewish 'universalism'. European Review of History 17: 541-49. [CrossRef]

Bauer, Bruno. 2000. The Jewish Problem. San Diego: Contrarian Press. First published 1843. 
Boyarin, Jonathan. 1996. Palestine and Jewish History: Criticism at the Borders of Ethnography. Minneapolis: University of Minnesota Press.

Boyarin, Daniel. 1997. Unheroic Conduct: The Rise of Heterosexuality and the Invention of the Jewish Man. Berkeley: University of California Press.

Boyarin, Daniel, and Jonathan Boyarin, eds. 1997. Jews and Other Differences. Minneapolis: University of Minnesota Press.

Butler, Judith. 2012. Parting Ways: Jewishness and the Critique of Zionism. New York: Columbia University Press.

Chakrabarty, Dipesh. 2000. Provincializing Europe: Postcolonial Thought and Historical Difference. Princeton: Princeton University Press.

Conforti, Yitzhak. 2006. Alternative Voices in Zionist Historiography. Journal of Modern Jewish Studies 4: 1-12. [CrossRef]

Davison, Neil. 1998. James Joyce, Ulysses, and the Construction of Jewish Identity: Culture, Biography, and 'the Jew' in Modernist Europe. Cambridge: Cambridge University Press.

Derrida, Jacques. 1985. The Ear of the Other. Edited by Christie McDonald. Translated by Peggy Kamuf. Lincoln: University of Nebraska Press.

Derrida, Jacques. 1999. Adieu to Emmanuel Levinas. Stanford: Stanford University Press.

Derrida, Jacques. 2002. Acts of Religion. Edited by Gil Anidjar. New York: Routledge.

Engelberg, Ari. 2015. Modern Orthodoxy in Post-Secular Times: Jewish Identities on the Boundaries of Religious Zionism. Journal of Modern Jewish Studies 14: 126-39. [CrossRef]

Feiner, Shmuel. 2002. The Jewish Enlightenment. Philadelphia: University of Pennsylvania Press.

Gift, Kristine. 2012. Sarah's Laughter as Her Lasting Legacy: An Interpretation of Genesis 18:9-15. In MJUR. Monmouth: Monmouth Coe College Press, pp. 99-110.

Gilman, Sander L. 1991. The Jew's Body. New York: Routledge.

Gilman, Sander L. 1993a. Freud, Race, and Gender. Princeton: Princeton University Press.

Gilman, Sander L. 1993b. The Case of Sigmund Freud: Medicine and Identity at the Fin De Siècle. Baltimore: Johns Hopkins University Press.

Grosz, Elizabeth. 1995. Space, Time and Perversion: Essays on the Politics of Bodies. New York: Routledge.

Henz-Piazza, Gina. 2004. Why Did Sarah Laugh? In Distant Voices Drawing Near: Essays in Honor of Antoinette Clark Wire. Edited by Holly E. Hearon. Collegeville: Liturgical Press.

Herzl, Theodor. 2018. The Jewish State. An Attempt at a Modern Solution of the Jewish Question. Whithorn: Anodos Books, New York: American Zionist Emergency Council. First published 1896.

Herzl, Theodor. 2009. Old New Land. Princeton: M. Wiener Publishing. First published 1902.

Hess, Tamar. 2016. Self as Nation: Contemporary Hebrew Autobiography. Lebanon: Brandeis University Press.

Idelson-Shein, Iris. 2014. Difference of a Different Kind: Jewish Constructions of Race during the Long Eighteenth Century. Philadelphia: University of Pennsylvania Press.

Irigaray, Luce. 1987. Speculum of the Other Woman. Ithaca: Cornell Univ. Press.

Kalmar, Ivan Davidson, and Derek Jonathan Penslar. 2005. Orientalism and the Jews. Lebanon: Brandeis University Press.

Kaniuk, Yoram. 1971. Adam Resurrected. [Adam Ben Kelev]. Translated by Seymour Simckes. New York: Atheneum. First published 1969. (In Hebrew)

Khanna, Ranjana. 2003. Dark Continents. Durham: Duke Press.

Khanna, Ranjana. 2007. Indignity. Positions: East Asia Cultures Critique 16: 39-77. [CrossRef]

Khanna, Ranjana. 2014a. "Unbelonging" Lecture for the Humanities "theory" Panel for the "Sensational Humanities" Conference, Cornell University, Society Ithaca, NY, USA, November 20. Available online: https://vimeo.com/112419281 (accessed on 20 November 2014).

Khanna, Ranjana. 2014b. Rex, Or the Negation of Wandering. In Deconstructing Zionism. Edited by Gianni Vattimo and Michael Marder. New York: Bloomsbury Publishing, pp. 133-45.

Leonard, Miriam. 2012. Socrates and the Jews: Hellenism and Hebraism from Moses Mendelssohn to Sigmund Freud. Chicago: University of Chicago Press.

Lévinas, Emmanuel. 1994. Beyond the Verse: Talmudic Readings and Lectures. Bloomington: Indiana University Press.

Levy, Lital. 2014. Poetic Trespass: Writing Between Hebrew and Arabic in Israel/Palestine. Princeton: Princeton University Press.

Librett, Jeffrey S. 2014. Orientalism and the Figure of the Jew. New York: Fordham Press. 
Loewenberg, Peter, and Irving Stone. 1970. A Hidden Zionist Theme in Freud's My Son, the Myops-Dream. Journal of the History of Ideas 31: 129-32. [CrossRef] [PubMed]

Marx, Karl. 2012. On the Jewish Question. Chicago: Aristeus Books. First published 1844.

Mosse, George L. 1992. Max Nordau, Liberalism and the New Jew. Journal of Contemporary History 27: 565-81. [CrossRef]

Nancy, Jean-Luc. 2000. Being Singular Plural. Stanford: Stanford University Press. First published 1996.

Nelson, Cary, and Gabriel Noah Brahm. 2014. The Case Against Academic Boycotts of Israel. MLA Members for Scholar's Rights. Detroit: Wayne State University Press.

Nordau, Max. 1897. Nordau's Speech to the First Zionist Congress. Available online: http://www.mideastweb.org/ nordau1897.htm (accessed on 19 March 2015).

Palumbo-Liu, David. 2015. Breaking Taboos, BDS Gains Ground Among Academics. The Nation. Available online: http://www.thenation.com/article/194233/breaking-taboos-bds-gains-ground-among-academics (accessed on 15 June 2019).

Pappe, Ilan. 2014. The Idea of Israel: A History of Power and Knowledge. London: Verso Press.

Peled, Yoav. 1992. From theology to sociology: Bruno Bauer and Karl Marx on the question of Jewish emancipation. History of Political Thought 13: 463-85.

Pellegrini, Ann. 1997. Performance Anxieties: Staging Psychoanalysis, Staging Race. New York: Routledge.

Penslar, Derek Jonathan. 1991. Zionism and Technocracy: The Engineering of Jewish Settlement in Palestine, 1870-1918. Bloomington: Indiana University Press.

Rolnik, Eran. 2013. Freud in Zion. London: Karnac Books.

Shafir, Gershon, and Yoav Peled. 2002. Being Israeli: The Dynamics of Multiple Citizenship. Cambridge: Cambridge University Press.

Shaked, Gershon, and Yaron Peleg. 1996. Through Many Small Windows, by the Back Door: An Introduction to Postrealistic Hebrew Literature, 1950-80. Prooftexts 16: 271-91.

Shohat, Ella. 2017. On the Arab-Jew, Palestine, and Other Displacements: Selected Writings. London: Pluto Press.

Slavet, Eliza. 2009. Racial Fever: Freud and the Jewish Question. New York: Fordham University Press.

Smith, Charles D. 2007. Palestine and the Arab-Israeli Conflict. Boston: Bedford/St. Martin's Press.

Strauss, Leo. 1965. Spinoza's Critique of Religion. Chicago: University of Chicago Press.

van Vliet, Netta. 2016. Review of Deconstructing Zionism: A Critique of Political Metaphysics. Critical Inquiry 42: 412-14. [CrossRef]

Vattimo, Gianni, and Michael Marder, eds. 2014. Deconstructing Zionism: A Critique of Political Metaphysics. New York: Bloomsbury Press.

Yakobson, Alexander, and Amnon Rubinstein. 2010. Israel and the Family of Nations: The Jewish Nation-State and Human Rights. London: Routledge.

Yerushalmi, Yosef Hayim. 1993. Freud's Moses: Judaism Terminable and Interminable. New Haven: Yale University Press.

Yiftachel, Oren. 2006. Ethnocracy: Land and Identity Politics in Israel/Palestine. Philadelphia: University of Pennsylvania Press.

(C) 2020 by the author. Licensee MDPI, Basel, Switzerland. This article is an open access article distributed under the terms and conditions of the Creative Commons Attribution (CC BY) license (http://creativecommons.org/licenses/by/4.0/). 
Article

\title{
When Piety Is Not Enough: Religio-Political Organizations in Pursuit of Peace and Reconciliation in Zimbabwe
}

\author{
Joram Tarusarira \\ Faculty of Theology and Religious Studies, University of Groningen, 9712 GK Groningen, The Netherlands; \\ j.tarusarira@rug.nl
}

Received: 27 March 2020; Accepted: 7 May 2020; Published: 9 May 2020

\begin{abstract}
In post-independence Zimbabwe, religion has been associated with piety and acquiescence rather than radical confrontation. This has made it look preposterous for religious leaders to adopt seemingly radical and confrontational stances in pursuit of peace and reconciliation. Since the early 2000s, a new breed of religious leaders that deploy radical and confrontational strategies to pursue peace has emerged in Zimbabwe. Rather than restricting pathways to peace and reconciliation to nonconfrontational approaches such as empathy, pacifism, prayer, meditation, love, repentance, compassion, apology and forgiveness, these religious leaders have extended them to demonstrations, petitions and critically speaking out. Because these religious leaders do not restrict themselves to the methods and strategies of engagement and dialogue advocated by mainstream church leaders, mainstream church leaders and politicians condemn them as nonconformists that transcend their religious mandate. These religious leaders have redefined and reframed the meaning and method of pursuing peace and reconciliation in Zimbabwe and brought a new consciousness on the role of religious leaders in times of political violence and hostility. Through qualitative interviews with religious leaders from a network called Churches in Manicaland in Zimbabwe, which emerged at the height of political violence in the early 2000s, and locating the discussion within the discourse of peace and reconciliation, this article argues that the pursuit of peace and reconciliation by religious actors is not a predefined and linear, but rather a paradoxical and hermeneutical exercise which might involve seemingly contradictory approaches such as "hard" and "soft" strategies. Resultantly, religio-political nonconformism should not be perceived as a stubborn departure from creeds and conventions, but rather as a phenomenon that espouses potential to positively change socio-economic and political dynamics that advance peace and reconciliation.
\end{abstract}

Keywords: peace and reconciliation; religio-political nonconformism; Zimbabwe; mainstream churches; piety; politics

\section{Introduction}

Since the early 2000s, a new breed of religious leaders that deploy relatively radical and confrontational strategies to advance peace and reconciliation has emerged. Rather than restricting pathways to peace to nonconfrontational approaches such as empathy, pacifism, prayer, meditation, love, repentance and compassion, these religious leaders have extended them to include demonstrations, petitions and critically speaking out. In doing so, they have redefined and reframed the meaning and method of pursuing peace in Zimbabwe and brought a new consciousness of the role of religious leaders in times of political hostility, especially that being radical and confrontational is not merely a stubborn parting from conventions but an approach that can bring new ideas and directions in the search for peace and reconciliation. This article argues that religious organizations operating outside the jurisdiction of the mainstream churches have challenged the view that there is a contradiction 
between hard, radical and confrontational approaches, and soft, piety and acquiescence approaches in pursuit of peace and reconciliation by religious leaders. In what follows, I give a brief overview of the socio-economic and political context out of which the religio-political nonconformist organization under study emerged. I proceed to discuss the approach of the mainstream church leaders, pointing out what the religio-political organization pointed out as the weaknesses of the mainstream religious leaders which paved the way for their emergence. Subsequently, I unpack and discuss the culture, organization and operations of the religio-political organization concerning peace and reconciliation.

\section{Whither the Socio-Economic and Political Situation in Zimbabwe}

Churches in Manicaland emerged in the early 2000s due to the socio-economic and political instability and violence that befell Zimbabwe. Zimbabwe was born on 17 April, 1980 after a protracted war of liberation. However, despite the reconciliation speech by the late former President (Prime Minister at the time) Robert Mugabe at independence, in which he urged former warring parties, blacks and whites to bury the past and focus on peace, reconciliation and the stability of the country, it never experienced true reconciliation. Instead, Zimbabwe has accumulated an array of conflict points which make the quest for peace and reconciliation imperative (Huyse 2003, p. 34). The conflicts were due to the contest for political and economic power between political parties, which created negative beliefs, attitudes and emotions, encouraging ordinary people to rise against each other on political grounds, thereby destroying the tapestry of relationships that formerly existed (Tarusarira 2016).

The decade beginning in the year 2000 came to be known in policy circles and scholarship as the crisis decade. It was characterised by degeneration of the country into violence, a sacrifice of the rule of law, a militarisation of the state and a collapsing economy. Resultantly, opposition politics increased in response to the political crisis, which was attributed to bad governance. Citizens blamed the constitution of the country for failing to stop the rot that was in government. The constitutional discourse thus set the oppositional political mood of the decade. After consensus in the country that there was a need to write a new constitution to reform governance, a civic organization called the National Constitutional Assembly (NCA) emerged to advocate the development of a people-driven constitution. The government feared that the move to change the constitution and the emergence of the NCA was going to paint it in a bad light since the elites in government were allegedly benefitting from the shortcomings of the existing constitution. To counteract the initiatives of the NCA, the government instituted its Constitutional Commission (CC), which produced a draft constitution that was rejected by the people in a referendum in the year 2000. This seemed to confirm the government's fears and was the first overt sign of people's disgruntlement with the Zimbabwe African National Union-Patriotic Front (ZANU PF) regime and an unprecedented defeat of the ruling party since independence in 1980. Action was needed quickly to mobilise and coordinate support by whatever means as there were impending elections. Some ZANU PF war veterans invaded commercial farms under the guise of a land reform programme. The land was the only remaining rhetorical source of mobilisation for ZANU PF (Dorman 2003, p. 848). Unruly gangs occupied the land, destroyed crops, confiscated livestock and equipment, and forced farm owners and their workers to flee during the preludes to the elections of 2000, 2002 and 2005 (Sachikonye 2011; Tarusarira 2016). The banning of the main opposition party, the Movement for Democratic Change (MDC) from campaigning characterized the election periods. Electoral violence and state-sponsored militias which harassed, intimidated and murdered MDC candidates and supporters became the signature of elections (Bratton and Masunungure 2011, pp. 23-24).

The regime introduced draconian laws. Cases in point include the Broadcasting Services Act, which was promulgated in 2001 to control electronic and print media. It claimed that its mission was to "provide world-class quality programmes and services that reflect, develop, foster and respect the Zimbabwean national identity, character, cultural diversity, national aspirations and Zimbabwean 
and pan-African values" (Chiumbu 2004, p. 30). ${ }^{1}$ Because the state feared insurrection, it introduced the Public Order and Security Act on the 22 January, 2002 to empower the state to "regulate" public gatherings, making it difficult for opposition movements to organise. Yet another law, the Access to Information and Privacy and Protection Act, was promulgated in 2002, allegedly "to make public bodies more accountable to the public and to protect personal privacy". In practice, it served to silence critical media and increase the influence of the Minister of Information (Chuma 2004, p. 134). Journalists and media houses were required to register, and foreign media were banned. Public media metamorphosed into a full-blown propaganda instrument, limiting public discourse to themes approved by the ZANU PF elites and "inventing traditions" (Tarusarira 2016). "Invention of traditions" refers to "a set of practices normally governed by overtly or tacitly accepted rules and of a ritual or symbolic nature which set out to inculcate certain values and norms of behaviour by repetition, which automatically implies continuity with the past" (Hobsbawm 1983, p. 1; 1994, p. 76). The Mugabe regime resorted to advancing political ideologies through patriotic history, manipulating history and nationalism in its favour. The regime's patriotic history's nationalist narratives exclude the voices of some political leaders from the history of the liberation war (Ndlovu-Gatsheni 2008).

The military - the heads of the army, police, air force, intelligence and prison charged with the mandate to protect national security - became an unofficial decision-making board reporting directly to Mugabe, thus able to act independently of cabinet decisions. Consequently, militaristic approaches became the default mode of governing the country. A case in point is Operation Murambatsvina, codenamed Operation Restore Order, which the regime implemented under the guise of cleansing cities of illegal business dealers and settlements in 2005. It left 700,000 urban Zimbabweans homeless (Tibaijuka 2005, p. 7). Sometimes people were forced to demolish their dwellings or source of income in winter. A major motive was allegedly political retribution against sectors of the urban population who had voted MDC as well as the desire to ward off possible urban uprisings (Sachikonye 2011, p. 27). Operation Maguta (having enough to eat) transferred the management of food production from the ordinary civil service to the army, partly to ensure that the troops themselves remained well-fed (Bratton and Masunungure 2011, pp. 26-27). The government launched Operation Mavhoterapapi (for whom did you vote?) after the presidential run-off in 2008, sacrificing democracy, the rule of law and the independency of the judiciary. It denied rights to information, freedom of association and minority rights. State officials ceased to be accountable, and elections lost credibility. Communities destroyed the tapestry of relationships that existed.

\section{Whither Mainstream Churches: Negative and Passive Peace-Making}

Against the deteriorating socio-economic and political environment, the historic mainstream churches and their apex bodies, the Zimbabwe Catholic Bishops' Conference (ZCBC), the Zimbabwe Catholic Churches (ZCC) and the Evangelical Fellowship Zimbabwe (EFZ), attempted several times to facilitate behind-the-scenes talks between the main political parties, ZANU PF and the MDC. In the language of social movements, the mainstream refers to a set of authoritative institutions that can and do maintain public order, dominate economic activity and justify exercising power and authority. Cases in point include upper layers of governments, corporations and religious institutions (Lofland 1996). The backchannel efforts by the mainstream church leadership are necessary to initiate political peace-making processes upon which social peace-making builds. While political processes may stop direct violence, that is, the physical violence that can be observed with the naked eye, such as bombs exploding or people being physically attacked with machetes, they do not address societal transformation. The mainstream churches were also rocked by divisions and ambivalent positions regarding their response to the crises. "Because of the lack of strong ecumenical cooperation, the ZCC,

1 At the time of writing these laws are set to be replaced by new ones, under the guise of political reforms. 
ZCBC and EFZ and other church bodies have not been influential in the formulation of government policy" (Makwasha 2011, p. 236).

This is not to sidestep some of the initiatives mainstream churches have undertaken in civic matters in the country. They participated in the constitutional process of 1999 and have issued fearless pastoral statements, which irked the ZANU PF government (Chitando and Manyonganise 2011, pp. 83-86; Ruzivo 2008). Such pastoral letters include "God Hears the Cry of the Oppressed", in which the Catholic bishops were "blunt and to the point" (Chitando and Manyonganise 2011, p. 84) regarding the crisis of leadership in the country. The pastoral letter provoked a ferocious response from President Mugabe. The ZCC issued a statement following the formation of the inclusive government in 2008, bemoaning the manipulation of democratic space and selective application of the law. The grouping Heads of Christian Denominations issued a statement in 2005 asking for people's freedoms to be observed (Chitando and Manyonganise 2011, p. 85). The point is that these bodies are not grassroots-based. They are far removed from the people. Their offices are located in big cities and inaccessible to ordinary people (Dube 2006, p. 46). Besides, the extent to which the pastoral letters trickle through to the common people in the workplace, families and even the local Christian communities is very limited (Chitando 2005, p. 143). By preferring backchannel negotiations, and issuing ritualistic pastoral letters, mainstream churches distance themselves from the people. They only realize negative peace, understood as the absence of direct violence rather than an affirmation or achievement of fairness, justice and social redistribution, the latter of which represents positive peace (Galtung 1996, p. 3). Peace incorporates feelings of well-being and a sense of flourishing (Wolterstorff 1983).

\section{Enter Religio-Political Nonconformist Organizations}

Religious nonconformists refer to those religious organizations that operate outside of the mainstream religious landscape, such as sub-groups of mainstream denominations, independent Christian congregations, minority denominations and religious socio-political organizations (Ganiel and Tarusarira 2012). The mainstream political establishment defines the reality claims of nonconformists as improper, implausible, immoral, false, threatening, corrupting, seditious, treasonous, blasphemous, despicable, or in some other way not respectable or deserving serious consideration (Lofland 1996, see Ganiel and Tarusarira 2012). Resultantly, nonconformists develop "a systematic counterculture, a modus operandi associated with those estranged from the centres of power and communication" (Comaroff 1985). The moment they develop a counterculture, they adopt a modus operandi that is "hard" rather than "soft". Hard approaches become necessary because politicians in Zimbabwe seem to have gotten used to the routine that at some point the mainstream church leaders will issue out pastoral statements condemning violence (soft approach), to which they (politicians) pay deaf ears (see Togarasei and Chitando 2011). They seem not to be moved by the pastoral letters. When this has happened, mainstream church leaders have not taken any further radical actions such as demonstrations. Religio-political groups like Churches in Manicaland (CiM) in Zimbabwe seem to expect radical and confrontational approaches from the mainstream churches, the absence of which has irked them.

This paper takes a case study approach to study CiM, which defines itself as an ecumenical gathering of church leaders representing Christian denominations and organizations in the province of Manicaland. At its inception, it had 40 churches and church-related organizations affiliated to it. These included the Catholics, Anglicans and Lutheran churches, the Apostolic Church of Pentecost, the Elim Pentecostal Church, the Pentecostal Assemblies of God, the United Apostolic Faith Church and the Zimbabwe Assemblies of God (ZAOGA), to name a few. It aimed to bring together as many Christian organizations as is possible (Manyonganise 2015). CiM is based in Manicaland Province. While other platforms such as Churches in Bulawayo and Churches in Masvingo have adopted its outlook, they are not its branches. Bulawayo and Masvingo are also provinces, like Manicaland. They, however, share notes on how to participate in civic matters as religious actors. Middle-aged religious males dominate the platform. Woman and youths are underrepresented. Manicaland is one of eight 
provinces in Zimbabwe. Situated in the east of the country on the borders with Mozambique, it has a population of approximately one and half million people. More than half of this number are Christians linked to different churches. Mutare is the capital of Manicaland and has a population of approximately 250,000. As of 2018, Zimbabwe has an estimated population of 14 million people. Of these, " 86 percent claim to be Christian, 11 percent reports no religious affiliation, less than 2 percent adheres uniquely to traditional beliefs, and less than 1 percent is Muslim". Of the total population, 37 percent is Apostolic, 21 percent Pentecostal, 16 percent other Protestant, 7 percent Roman Catholic and 5 percent other Christian. Many Christians also associate themselves with traditional practices, thus syncretism is rife. There are also small numbers of Greek Orthodox, Jews, Hindus, Buddhists and Baha'is (U.S. Department of State 2018).

\section{Methodology}

To study this organization, I adopted a case study method to profile the beliefs and practices of CiM. I conducted eight semistructured interviews with its members, guided by questions and themes that revolved around its ideology/culture and organisation as well as how it negotiates the environment to challenge the mainstream ethic. The length of the interviews ranged from forty-five minutes to one hour. To recruit my interviewees, I relied on snowball sampling. Interview partners referred me to their fellow members. This was the best method of recruitment considering that the security of the interviewees was of concern since they were challenging political elites as well. To guard against undue homogeneity, I used other methods such as a review of grey literature. I also interviewed other people who were not members of CiM. At the beginning of the interviews, I explained to the interview partners that I was the only one who would access the interview recordings and transcripts, and I was going to keep them safe. The transcripts were strictly for academic purposes and nothing more. The interviewees were free to withdraw from the interview without any consequences, had the right to refuse to answer any questions, and their responses would remain anonymous. I proposed to use pseudonyms since the topic of research was politically sensitive. I also deployed the snowball sampling from different angles to be able to be directed from different ways and have a heterogeneous sample of respondents within the organization.

While this article relies heavily on the interviews, my analysis was influenced by other research methods as well. I had email communication with some of its key members, who provided me with background information. I consulted grey literature, which included press statements, publications and booklets. Grey literature helped me to trace the genealogy of CiM, gather information about its official positions, reconstruct its development and acted as a canvass against which to understand the general discourse within which it operates. I also gathered data from online social media such as Facebook, which provided unexpected data. To analyse the data, I systematically coded it according to preset and emergent major themes or codes.

The analysis of the data showed minimal disagreement regarding the ideology and practice of CiM. This can be accounted for by the fact that members studied CiM before committing to it. Absence from participating in some activities demonstrated some of the disagreements. CiM had room for this. A case in point is when some members of the Zimbabwe Assemblies of God in Africa (ZAOGA) who did not subscribe to the radical and confrontational approaches of CiM, such as demonstrations and distributing pamphlets with civic materials at bus termini, chose to take a lead in activities that centred around humanitarian aid, prayer and worship. One of the three prominent Bishops who were part of CiM jumped ship at some point and joined those who supported the ruling regime.

\section{The Discourse and Practice of CiM in Pursuing Peace and Reconciliation}

The mission of CiM was to challenge both the mainstream churches' culture of silence and the violence that had engulfed the Zimbabwean political field. CiM is an "ecumenical" gathering of members from Christian denominations and organisations in the eastern province of Zimbabwe called Manicaland. It was formed in 2000, at a time of great uncertainty, intimidation and violence ahead of 
the elections. It claims that it aims to "seek the guidance of the Holy Spirit in taking action to promote tolerance in society, to give direction to public decision-makers and to enable our people to live Gospel values and principles" (Churches in Manicaland 2006). The use of the word "churches" does not refer to the institutional churches but to individual Christians, who would otherwise not be able to speak at high-ranking platforms such as those of mainstream bodies (Mkaronda 2003, p. 30). We see that the organization does not want to divorce itself from the traditional and recognized churches entirely, hence strategically retains the word "church" in its name. CiM describes itself as "strictly non-partisan regarding party politics and ... available to all for counselling, pastoral care and the building of a Christian vision for ... society" (Churches in Manicaland 2006). An official said:

CiM is a platform of church leaders, laity and clergy who come together to see how best they can intervene in situations that need intervention, especially when we look at the political terrain in Zimbabwe. It started in 2000 during the height of political violence. Manicaland was also very much affected, so the church leaders thought it wise to come together and try to intervene ... We focus on human rights. Hence even where there is an unfair distribution of resources, we try to see how we can intervene and talk to the powers that be.

The formation of CiM centred on direct intervention in response to the cries of the victims of political violence. A founding member of CiM described to me how the original group of 14 religious leaders came together, assisted by the World Council of Churches, to begin the process of reflecting on the Zimbabwean crisis. Because these clergy felt they needed high-profile people to gain some legitimacy, they approached Bishop B of the Anglican Church and Bishop C of the Roman Catholic Church to be part of the organisation. The founding member noted that starting to talk about political violence was not easy after a long time of avoiding the topic within religious circles. Eventually, there was consensus that there was a crisis and the churches in Manicaland had to intervene, she asserted. They called together as many churches as they could, regardless of denomination. Their next meeting had about eighty people. They started these meetings against the background of rumours that the Chinese, who have warm political relations with the Zimbabwean ruling regime and carry out many government technical and infrastructural projects, had mounted big satellites with which they could, on behalf of the ruling party, see everyone's vote.

Regarding their motivation to become members of CiM, some asserted that they felt that they had a biblical mandate to participate in issues that affect their lives. Others joined through the encouragement of already participating members. Some said that the desire to pursue peace and justice issues was inborn. As one respondent told me, "I would see myself since childhood trying to advocate for other people, when I feel that injustice was being done, hence when I heard about CiM and was invited to a meeting, I just clicked in."

To justify its radical and confrontational approach to peace, CiM members say they feel compelled to react to socio-economic situations, and in that process, they make their faith relevant. Unlike what might be called secular civil society organisations, CiM draws upon both the Old and New Testament texts and figures. Bishop B of CiM had the following to say:

You look back to the time of Micah, Hosiah, and Amos. State religion was there; the Pharisees were there; they had lost the vision, so God had to keep on sending his prophets to tell the Pharisees that what they were doing was wrong. The prophets are not condemning ordinary people; they are condemning the King and his cronies, so it is that kind of prophetic ministry that will make some people look redundant.

CiM members also deploy scriptural texts to argue that they do not separate the religious, the social, the economic and the political. For them, the spiritual is entangled with the socio-economic and political, so they need to deal with life holistically. In the same way that the Old Testament prophets condemned not only religious prostitution but also social and political institutions, so do 
they. They mention prophets like Amos, who was concerned with trade, for instance, manipulating trade scales, that is, economic issues. Prophets were concerned with political issues, notably about how kings were using or abusing their power, so they argue. Politicians have admonished them for their stance, who have argued that as religious leaders, they should leave politics to politicians.

“No, we can't. There is no way you can separate the two. The problem comes when the church becomes partisan and supports a particular party", remarked a respondent. The relationship of religio-political nonconformist organizations like $\mathrm{CiM}$ with the political system contrasts with that of the mainstream churches, the latter of whom are silent, silenced, co-opted or sometimes express outright pronouncements of legitimation in the face of political violence. The mainstream churches seem compromised by bureaucracy, conservatism and proximity to political power. The emergence of organisations such as CiM confirms that in the face of a crisis, dissenting leaders from within may emerge and forge alliances with outsiders. It also shows that "in whatever sort of political system, widespread and profound disaster reopens the question of legitimate authority and the effective leadership in the conduct of the church leadership" (Fields 1982, p. 353).

CiM, as I pointed out above, describes itself as strictly nonpartisan regarding party politics (Churches in Manicaland 2006). My observation was also that it had easy access to non-ZANU PF (ruling party) politicians, thereby casting doubt on its nonpartisanship claim and weakening its criticism that mainline churches court ZANU PF politicians. A case in point is when Bishop B spoke at an opposition MDC campaign rally in 2013. He was reported in a Facebook post of the MDC to have

urged all Zimbabweans from all walks of life to rally in commitment behind President' Tsvangirai (the late leader of the opposition). He also noted that we need humble people with love to lead us into a new Zimbabwe, saying that an open palm (the symbol of the MDC) is used to rebuild compared to a closed fist (the symbol of the ruling party ZANU PF) which is used to destroy. He thanked God and called upon Him to usher our nation into a new Zimbabwe which we all need. (MDC Facebook Post 2015)

Surprised by this position of a prominent figure of CiM, I asked one of the founding members about this, and he emailed:

It does not sound like him. Is it possible that he did not say this but someone is deliberately misquoting him? If he did say it, I would not agree with his approach. If (Bishop B) did say what he is quoted as saying, he could be asked to give reasons as to why he adopted this approach. It seems to be out of character with the person that I knew.

This might suggest that principles and action do not always agree, or that while in general there was much agreement amongst the members of $\mathrm{CiM}$, there are cases when there were differences. Above we saw members of ZAOGA deciding to participate only in prayer activities, and here we encounter Bishop B participating at an event of an opposition party. My email correspondent shows disagreement with Bishop B's approach.

\section{The Discourse and Practice of CiM in Pursuing Peace and Reconciliation}

Peace and reconciliation are central to the mission of CiM. What is significant and in line with the argument of this article is that not as expected of religious leaders in Zimbabwe, CiM takes radical, confrontational and grassroots-based approaches to pursue political objectives. It defines reconciliation as "dealing with pain and resentment, hurt and anger leading to healing" (Churches in Manicaland 2006, p. 11). Some members of CiM feel that contrition or repentance is of paramount importance in the process. Bishop B describes reconciliation as a process of "re-membering" with the political other(s) after losing membership through committing atrocious acts: 
Genuine reconciliation includes contrition, being inwardly sorry, and if you do not demonstrate that contrition, there is no reconciliation. I can't say, 'Forget about it, it was child's play.' It is warding off the problem. Reconciliation means a person has to swallow his or her pride. It demands a lot of humility-giving oneself on the table and asking to be helped to be 'one of us again' because he or she is no longer one of us. That is when for me reconciliation begins.

In his account of what reconciliation entails, Bishop B accentuates a demonstration of contrition. He emphasizes contrition and being sorry. For him, without an apology, there is no reconciliation. His emphasis on contrition and being inwardly sorry intersects with what I have elsewhere called transformative apology, understood as an apology that comes from deep within the wrongdoer's heart and mind, one that ruptures ideas, narratives and ideologies that made the wrongdoer see it justified in the first place to commit the wrong (Tarusarira 2019). Bishop B is thus against instrumental apologies which guarantee neither the rupture of the epistemic bedrock of wrongdoing, nor that the same wrongdoing will not be repeated to another person.

In Zimbabwe, there is a tendency to separate religious approaches to peace and reconciliation from political ones. It is upon this distinction that religious approaches to dealing with violence and its legacies are classified as "soft", thus possessing soft power (Haynes 2012) and characterised by piety, while political approaches are categorised as "hard" and not bent on piety. The distinction between soft and hard approaches resonates with the concept of religious soft power which was developed by Jeffrey Haynes in discussing how religion affects foreign policy (Haynes 2008), as an extension of Nye (1990) concept of "soft power". Soft power refers to the ability of ideas to make an influence or appeal to a targeted audience without using "hard power" that is often associated with state power. These ideas shape the values and norms of international and local institutions. The concept of soft power was introduced by Nye (1990) to show that hard power is not the only way to achieve political goals. Power is about influencing others towards desired goals. This can be done through the use of sticks, carrots or attraction. Soft power is thus defined as "the ability to get what you want through attraction rather than coercion or payments." Its power lies not necessarily in influence, but in attraction of the culture, ideas, policies or principles. It thus appeals and does not force. It is about persuasion and encouragement. It is contrasted with the notion of "hard power", that is, military or economic influence, involving overt leverage and/or coercion (Nye 2005; Haynes 2009). Religious soft power should include cultural (including religious) actors who seek to influence foreign policy by encouraging policymakers to incorporate religious beliefs, norms and values into foreign policy (Haynes 2008.) It is when religious organisations seek to influence using religious beliefs, norms and values (Haynes 2009).

While CiM is not opposed to religious soft power, which it also deploys since it is an organisation founded on certain ideals and values, it does not limit itself to it. Religious soft power is connected to piety, but as Bishop B has shown, that is not enough. Nye (2005) acknowledged that soft power works in situations where there are willing interpreters and receivers. We have seen already that this is not the case in Zimbabwe where politicians are not willing interpreters and receivers, but pay deaf ears to the soft power of mainstream churches. Furthermore, soft power tends to produce a diffuse effect, creating general influence rather than producing early observable specific action, which is required in times of violence, like the context under discussion in Zimbabwe. Related to this is that soft power is relevant for what are called "milieu goals", like shaping an environment conducive to democracy, but less relevant to immediate goals like preventing an attack and violence, as we see in the Zimbabwean context in the 2000s. Confronted with these limitations of soft power, CiM appreciates what might be called "hard power", which in this case is represented not by guns, bombs and heavy artillery, but by radical and confrontational demonstrations and petitions. 
CiM challenges these distinctions and bridges the religious and socio-political dimensions of reconciliation (see Porter 2003). Unlike in the past when the resolution of the conflict was discussed mainly in political terms of democracy, justice, equality, freedom, rights, stability and the rule of law, today there is an increasing recognition of the importance of terms such as healing, repentance and forgiveness, which were once largely restricted to the religious domain. This intermingling marks the recognition of reconciliation as a political and cultural priority. In describing reconciliation, my CiM informant spoke of "contrition", "inner sorry", "humility", "repentance" and "forgive me". "Forgetting" was ruled out as an option having been associated with the Christian concept of forgiveness in Zimbabwe through the dictum "forget and forgive" at independence in 1980, which I alluded to earlier. Bridging the religious and socio-political dimensions addresses the fear that reconciliation might be no more than a cheap religious, specifically Christian, process which seems to make a necessary connection between apology and forgiveness.

CiM members emphasize that reconciliation is not only political but societal as well. Political reconciliation, which tends to be associated with the top religious, political and military leadership of society or what is called Track 1 diplomacy, does not necessarily translate to the restoration of broken relationships in communities. Yet, communities provide the cement for sustainable reconciliation in society. Thus, CiM members advocated a platform that would facilitate a nationwide process of national healing. They believe that there must be a system that gives perpetrators of violence no option to avoid telling what happened. They argue that, in the context of Zimbabwe, a politically led process is not productive, because the powerful will protect themselves. Rev. D said:

As long as there are people who have power and are unreachable, because they are so powerful, the process will not get anywhere. What we would like to see happening is the formation of an 'independent' body to spearhead this process, which would consult or bring onboard political players. Those who have been perpetrating violence for years seem to be influencing from behind. I would have loved to see independent people like heads of churches and perhaps lawyers for human rights.

Mrs A echoed his sentiments: "what is needed is not a composition of appointed personalities", but "a process that takes on transparency and people feeding in and saying what they want". It was clear that the call for an independent body and the suggestion for church leaders to lead the process was influenced by South Africa's Truth and Reconciliation (TRC), which was dominated by religious leaders, prominent among them being Archbishop Desmond Tutu and Rev. Alex Boraine, the Chair and Deputy respectively. It must be noted, however, that the dominance of religious leaders in South Africa's TRC was not without concerns from representatives of other religious traditions who felt that they were not represented. CiM respondents did not suggest traditional leaders, presumably because the traditional leaders had lost moral credibility because they were co-opted by the ruling regime. Notable here is that CiM members do not mince their words and are not "soft" with the process of peace and reconciliation, as demonstrated by its members' "hard" stance regarding the politicians whom they argue should not be allowed to get away without telling the truth of what they did during the periods of violence. Instead of only dialoguing and continuously engaging them, as would be advocated by the mainstream churches, CiM's nonconformist character mandates it to take robust approaches that compel politicians to be accountable for what they might have done.

Truth-telling was pointed out as a precondition for forgiveness. While truth-telling is generally agreed to be an indispensable element of the reconciliation process, it is not straightforward; it is delicate, sensitive and complicated. The caution would be that it needs not to be taken as a way of escaping justice, especially in cases where truth is exchanged for freedom, as was the case in the South African TRC, where truth-telling was traded for amnesty. No wonder Prof. A said, "Is it possible to just ask people to forgive each other? It will not work because the truth is not out. Truth and justice create healing and reconciliation... subjecting that truth to justice, then you get healing and you get reconciliation." This truth must be gathered from the grassroots people around the country, the majority 
of whom are victims of the contest between the political elites. Rev. Dr A affirmed the need to hear the stories of ordinary people, saying "We need people vakadimurwa maoko (who had their hands cut off) to tell their stories and what they want, we need people from Matabeleland massacres in the early 1980s to tell their stories." Truth-telling, healing, reconciliation and forgiveness were linked by Bishop A:

There is no way that there is going to be peacebuilding and national healing without truth-telling because only when one tells the truth even before anything happens that brings about some sort of mutual healing. After the truth, we then look at healing and after justice people can then talk about forgiveness and reconciliation is likely to follow.

Mr A confirmed this position: "It is important for the perpetrators of violence, who were involved in destroying property and people's lives, to own up to their actions and acknowledge they were wrong and that they are seeking to turn over a new leaf." Repentance and reparations are possible in cases where stolen goods can be returned or compensation made for destroyed property. Mr B said that the perpetrator should be able to say "I am sorry, what should I do?" The truth involved here comes from the victims and the perpetrators of the abuses. (Tutu 1999) calls this social truth, that is, truth gathered from social interaction, discussion and debate. CiM, therefore, calls for a comprehensive and rigorous process of reconciliation rather than a mere cheap and pious process that covers up for perpetrators.

\section{Repentance, Apology and Forgiveness}

In the discourse of reconciliation, influenced by Christian ethics, repentance is connected to an apology. When the offender demonstrates sorrow and assumes responsibility, the victim may feel drawn, if not pressured, to offer forgiveness. In South Africa's TRC, clergymen such as Desmond Tutu were criticised for pushing for forgiveness from the victims (Tutu 1999). There is a concern that forgiveness was emphasised much more than justice and accountability (Shore 2012). CiM members linked justice, truth-telling and forgiveness. Rev. D said:

We want justice. We want people to be able to confess, tell us the story, how they got involved, why they got involved and that they are sorry to have been involved, and then those who have been hurt and those who have been inflicted and suffered and have lost will then say okay, we realise this happened yesterday, so we accept that you are asking for forgiveness.

Perpetrators need to acknowledge their wrongdoing, argued Fr B, and it is expected that the victim will accept the apologies offered by the perpetrators (see also Waziweyi 2011, p. 96). This expectation, however, as we will see below, puts pressure on the victim to forgive without taking into consideration how much the victim feels hurt and how much time he or she needs to heal (Tarusarira 2019). This expectation to forgive should not be another way of saying that the victims ought to forgive, it just means that more often than not victims forgive when an apology has been offered. Apologies well-received by the wronged person can influence a shift in attitude and may inspire forgiveness (Tarusarira 2019.)

Fr B, thus, perceives truth-telling and justice as preconditions for forgiveness because victims want to know for what they are forgiving a person and for that the perpetrator of violence has to describe the wrong they did (see Tutu 1999). Were the victim to forgive without knowledge of the truth, they would remain haunted by unanswered questions, and this can stifle healing. They could remain in what Philpott calls "wounds of ignorance", where the surviving victims suffer from ignorance about what happened to their family and friends violated during the violence and how that happened, for instance who pulled the trigger that killed one's relative (Philpott 2006). Only truth-telling by the wrongdoer can adequately address this form of woundedness. The characterization of reconciliation by the respondents features "soft" words such as repentance, contrition, healing and forgiveness. However, they do not hesitate to invoke "hard" terms such as accountability, justice and confrontation when need be, thus challenging that religion is always about piety. 
What is instructive from the respondents' position regarding forgiveness is that it goes beyond its therapeutic dimension or its implementation as a practice of faith. Forgiveness is generally understood as the "willingness to abandon one's right to resentment, negative judgment and indifferent behaviour toward one who unjustly hurt us, while fostering the undeserved qualities of compassion, generosity, and even love towards him or her" (Enright et al. 1998). By connecting forgiveness to justice, Fr B concedes to the abandonment of one's right to resentment, but also leaves room for the victims to exercise that right as well. Mainstream churches would not see the two coexisting. CiM perceives reconciliation as both individual and societal, with the individual embedded in the social dimension (Tarusarira 2019). This is telling considering that often victims are advised to let go and forgive even without having received justice or knowing the truth. To forgive and let go is presented as standing on high moral ground. Some have argued that forgiveness is meant to free the victim from being held hostage by anger and resentment (see Lennon 2009). Thus, to forgive should not be dependent on anything. Zehr (2005, p. 47) has argued:

Forgiveness is letting go of the power the offence and the offender have over a person. It means no longer letting that offence and offender dominate. Without this experience of forgiveness, without this closure, the wound festers, the violation takes over our consciousness, our lives. It, and the offender, are in control. Real forgiveness, then, is an act of empowerment and healing. It allows one to move from victim to survivor.

The respondents challenged the understanding that the victim will transcend their victimhood and psychic preoccupation with a perpetrator. It is a slippery slope on which the focus might shift from the victim to the perpetrator. In the final analysis, forgiveness will serve the perpetrator, who will appear to be wounded and begging to be readmitted into the realm of moral humanity. The burden of rehumanizing the perpetrator falls on the shoulder of the victim (see Saunders 2011).

\section{Justice and Reparations}

The balance between retributive and restorative justice often puts CiM members in a bind. Retributive justice tends to be associated with the liberal secular critique, rather than with religion whose members are expected not to focus on punishment or retribution. Fr B expressed the dilemma that sometimes ensues amongst the members regarding restorative and retributive justice:

Restorative justice is good, in that we are trying to restore what has been destroyed. But again, some things cannot be restored. If a family loses a member, there is no way we can restore that though again punitive justice can act as a deterrent, because in Zimbabwe the culture of impunity has gone on for too long. And it's now very difficult to deal with that, so some form of punitive justice, especially for serious crimes like murder, rape, I would say let's go for punitive justice.

Fr B concurred that some form of restorative justice concerning people who lost property and their livelihood due to political violence must be done. Demands for compensation are understandable where people are struggling to eke out a living. While CiM emphasises restorative justice, retributive justice is not ruled out as a deterrent measure against a culture of impunity (Waziweyi 2011, p. 66). It is here that it accentuates retributive justice in a way that mainstream churches do not do.

Regarding retributive justice through reparations, Bishop B referred to the Old Testament: "In the OT reconciliation meant that if you stole my cow, for genuine reconciliation to occur, you have to pay four, not one." Asking for compensation for what one has taken or making up for a crime committed is biblical. Fr A had great respect for the African tradition, in this case, specifically the Shona religion. He remarked, "I am arguing that even traditional leaders can play a part. If I took your chicken, I can go to the traditional leader and say, I took his chicken and I want to give it back. We can resolve that at that level." This resonates with Waziweyi's assertion that among the Shona, the wronged used to spell 
out what he or she wanted (kubata makuku) as payment if they were brothers or relatives, and kuripa as compensation if not related (Waziweyi 2011, p. 65). In this way, judiciary costs are lowered. Restitution is, however, easier to deal with when only one side is wrong, but not when both or all sides in the conflict have lost property. Who will compensate whom, and what about those permanently injured, let alone those who died, becomes the question.

What we see here is that while CiM comprises Christian members, they do not underestimate the role of African philosophy and culture. Kubata makuku and kuripa, outlined above and along with others, are summarized in the African philosophy concept of ubuntu/unhu-a person is a person with or through other people (see Mbiti 1969, pp. 108-9; Tutu 1999, pp. 34-36). Ubuntu facilitates seeing oneself in another person. This approach thus changes the perspective of dealing with the conflict. While not opposed by the mainstream churches, most of the time the mainstream churches promote Christian values of dealing with the conflict and tend to be silent on African philosophical and cultural values. CiM foregrounds African philosophy and culture's connection to both retributive and restorative justice and truth-telling.

\section{CiM's Approaches to Peace and Reconciliation}

CiM organises several activities to create spaces for peace and reconciliation. These activities include workshops with pastors, in whom they have an interest because they have access to many people through their churches. They also engage the chiefs, who are expected to embody the societal values of peace and reconciliation. The majority of CiM members happen to be pastors and church people who share some values, even though they may differ on strategies of putting them into practice. It has also been the mission of CiM to change the perspective of other pastors that politics belongs only to politicians involved in partisan politics. To this end, CiM organises public meetings around the prayer worship idea, where different churches are invited for an ecumenical prayer event.

At the height of the violence, CiM created rapid response teams to back up local churches by reacting to reports of incidents of violence. It also created race relations (considering the tensions that had developed between the war veterans and white commercial farmers), youth and research teams. It engaged in direct services such as providing comfort, food and shelter to victims of the crisis (Mkaronda 2003, p. 39). In cases of injustice, they deployed the justice and peace commissions to facilitate litigation. For the brutalised and violated, it provided medication and counselling. To advocate a change of policies, it engaged politicians and other authorities in dialogue meetings. For instance, it contacted the Governor of Manicaland province and asked her to make a statement against violence, invited the chief of police and the Electoral Commission to issue public statements on security and electoral processes, respectively. It also delivered its publications and statements to the Governor of Manicaland, political and administrative heads and Members of Parliament, and sent delegations to discuss issues with national political leaders who came from Manicaland Province. It talked to MPs after elections to outline the expectations of communities.

As an organization, CiM issues several pastoral letters and press statements such as the compendium The Truth Will Make You Free (2006), which addresses various issues in the political sphere. Rev D shared that they deconstruct their pastoral letters and statements and take them down to the grassroots level, discussing them with the people (see Churches in Manicaland 2006, p. ii). Cases in point include the distribution of leaflets and pamphlets with civic information during elections, at public bus termini for travellers to take with them to the remotest places of the country. Such activities have not been witnessed amongst those undertaken by the mainstream churches. They would not be perceived as activities to be undertaken by religious leaders, but instead by political enthusiasts. But here we see a different modus operandi that links secular and religious approaches, creating a resourceful archive that caters for Zimbabwe's population, which for the most part does not distinguish between the religious and the secular. Analysing the interviewees' responses and perusing their grey literature shows that CiM's theoretical and practical tools close the gap between being a merciful, peaceful and forgiving religious person, and demanding that perpetrators of atrocities face justice, the 
truth of past atrocities be told, reparations be made and apologies be expressed. Instead of just dealing with the individual suffering of victims, the respondents advocate systems and structures that address the perpetrators of atrocities and safeguard reconciliation. This is not to intimate that mainstream churches do not call for justice and truth. Mainstream churches' para-organizations like the Catholic Commission for Justice and Peace (CCJP), which were radical during the liberation struggle and the early years after independence, vigorously challenged political violence. But the situation has since changed. In a personal email communication, an attaché to the CCJP wrote to me:

The Zimbabwe Catholics Bishops Conference (ZCBC) seems to be tightening its grip on CCJPZ activities. The process (of issuing press statements) is more bureaucratic. A press statement for print media has to be approved by at least three bishops before it is allowed in the public domain. Given the tight schedules of most of the bishops, some press statements are approved late when the information on them is no longer relevant.

To be noted is that CCJP in the 1970s enjoyed relative autonomy from the Catholic Bishops' Conference and its opinion did not have to be viewed as the official position of the bishops (Gundani 2001, p. 72). It spoke with an independent voice, sometimes at odds with that of the bishops (McLaughlin 1996, p. 4), thus could afford to be nonconformist. This allowed the organisation to be quicker and more effective than it arguably is now. It possessed qualities of a religio-political nonconformist organisation, and the popularity it attained can be attributed to that.

\section{Conclusions}

This article set out to argue that the pursuit for peace and reconciliation in Zimbabwe has been taken to another level by religious leaders operating outside the jurisdiction of the mainstream churches in a move that I have called religio-political nonconformism. While upholding the importance of religious soft power (Haynes 2008, 2009), its limitations, which resonate with those of soft power in general (Nye 1990), have prompted religio-political organizations such as CiM in Zimbabwe to invoke hard power, in the form of radical and confrontational approaches. The tendency to accentuate the soft power of religion might obscure the potential and necessity of hard power from religio-political organisations. Instead of sticking to only to the soft approach in pursuing peace and reconciliation, which is associated with religious actors in Zimbabwe, the nonconformist groups have gone for radical and confrontational strategies. This has influenced the public's understanding not only of how religion operates in the public sphere, but also shown that the dynamics of reconciliation such as apology, forgiveness, truth-telling and justice can be pursued in a nonconformist, radical and confrontational way when need be. Furthermore, their approaches have indicated that these dynamics of reconciliation are neither cast in stone nor waiting out there to be discovered. By calling for truth-telling and justice as prerequisites, they redefined and shielded reconciliation from abuse by those in power. The ruling party has a history of burying the truth. A case in point is when the government refused to make public the report that was produced by the Catholic Commission for Justice and Peace on the massacres that took place in the early 1980s in Matabeleland and Midlands provinces (Catholic Commission for Justice and Peace in Zimbabwe[1997] 2008). Truth-telling is taken beyond its therapeutic use by the victim to being a foundation for justice as well. The nonconformists redefine reconciliation as more than being sorry, forgiving and forgetting. They have as well redefined key elements of reconciliation such as apology and forgiveness so that they do not make reconciliation cheap, a charge levelled against Tutu (1999) forgiveness during the South African Truth and Reconciliation Commission. In so doing, they have call for transformative apology and forgiveness. In general, nonconformists have problematized approaches to peace and reconciliation, and the article argues that the approaches are discursive and variegated, multiple and can appear to be inconsistent. They are contingent on and constructed according to circumstances. So are the pathways to pursue them, they are not fixed but context-specific. The upholding of tradition and culture, which are different and dynamic, through Ubuntu philosophy demonstrates this point. To understand the dynamics of religio-political 
organisations, we should not only consider the beliefs and values which define them, but also their practical actions, because adherents to religions do not always follow the dictates of their religion. Restricting analyses to belies and creeds will obscure the lived religion dimension of religious agents. Ultimately this article has shown that hard approaches are not a stubborn departure from the established conventions, but have the potential to positively influence and change socio-political dynamics in the pursuit of sustainable peace and reconciliation.

Funding: This research received no external funding.

Conflicts of Interest: The author declares no conflict of interest.

\section{References}

Bratton, Michael, and Eldred Masunungure. 2011. The Anatomy of Political Predation: Leaders, Elites and Coalitions in Zimbabwe, 1980-2010. DLP Research Paper 9. Available online: http://www.dlprog.org/newsevents/newpaper-on-the-anatomy-of-political-predation-in-zimbabwe-.php (accessed on 7 June 2012).

Catholic Commission for Justice and Peace in Zimbabwe. 2008. Gukurahundi in Zimbabwe: A Report on the Disturbances in Matabeleland and the Midlands, 1980-1988. New York: Columbia University Press. First published 1997.

Chitando, Ezra, and Molly Manyonganise. 2011. Voices from Faith-based Communities. In Zimbabwe in Transition: A View from Within. Edited by Tim Murithi and Aquilina Mawadza. Auckland Park: Institute for Justice and Reconciliation, pp. 77-111.

Chitando, Ezra. 2005. In the Beginning was the Land': The Appropriation of Religious Themes in Political Discourse in Zimbabwe. Africa: Journal of International African Institute 75: 220-39. [CrossRef]

Chiumbu, Sarah. 2004. Redefining the National Agenda: Media and Identity-Challenges of Building a New Zimbabwe. In Media, Public Discourse and Political Contestation in Zimbabwe. Edited by Henning Melber. Uppsala: Nordic Africa Institute.

Chuma, Wallace. 2004. Liberating or Limiting the Public Sphere. In Zimbabwe: Injustice and Political Reconciliation. Edited by Brian Raftopoulos and Tyrone Savage. Cape Town: Institute for Justice and Reconciliation, pp. 119-39.

Churches in Manicaland. 2006. The Truth Will Make You Free: A Compendium of Christian Social Teaching. Mutare: Churches in Manicaland.

Comaroff, Jean. 1985. Body of Power, Spirit of Resistance: The Culture and History of a South African People. Chicago: University of Chicago Press.

Dorman, Sarah. 2003. NGOs and the Constitutional Debate in Zimbabwe: From Inclusion to Exclusion. Journal of Southern African Studies 29: 845-63. [CrossRef]

Dube, Jimmy G. 2006. A Socio-Political Agenda for the Twenty-First Century Zimbabwean Church: Empowering the Excluded. Lewiston: Edwin Mellen Press.

Enright, Robert D., Suzanne Freedman, and Julio Rique. 1998. The Psychology of Interpersonal Forgiveness. In Exploring Forgiveness. Edited by Robert D. Enright and Joanna North. Madison: University of Wisconsin Press, pp. 46-47.

Fields, Karen E. 1982. Charismatic Religion as Popular Protest: The Ordinary and the Extraordinary in Social Movements. Theory and Society 11: 321-61. [CrossRef]

Galtung, Johan. 1996. Peace by Peaceful Means: Peace and Conflict, Development and Civilization. Oslo: International Peace Research Institute and Sage.

Ganiel, Gladys, and Joram Tarusarira. 2012. Religion, secular democracy, and conflict resolution in Zimbabwe. In The Ashgate Research Companion to Religion and Conflict Resolution. Edited by Lee Marsden. Farnham: Ashgate Publishing, pp. 99-118.

Gundani, Paul. 2001. Changing Patterns of Authority and Leadership: Developments in the Roman Catholic Church in Zimbabwe after Vatican II (1965-1985). Harare: University of Zimbabwe.

Haynes, Jeffrey. 2008. Religion and foreign policy making in the USA, India and Iran: Towards a research agenda. Third World Quarterly 29: 143-65. [CrossRef]

Haynes, Jeffrey. 2009. Transnational Religious Actors and International Order. Perspectives 17: 43-70.

Haynes, Jeffrey. 2012. Religious Transnational Actors and Soft Power. Farnham: Ashgate. 
Hobsbawm, Eric J. 1983. Introduction: Inventing Traditions. In The Invention of Tradition. Edited by Eric J. Hobsbawm and Terence Ranger. Cambridge: Cambridge University Press, pp. 1-14.

Hobsbawm, Eric J. 1994. The Nation as Invented Tradition'. In Nationalism. Edited by John Hutchison and Antony D. Smith. Oxford: Oxford University Press, pp. 76-83.

Huyse, Luc. 2003. Zimbabwe: Why Reconciliation Failed. In Reconciliation after Violent Conflict: A Handbook. Edited by David Bloomfield, Teresa Barnes and Luc Huyse. Stockholm: International Institute for Democracy and Electoral Assistance, pp. 34-39.

Lennon, Brian. 2009. So You Can't Forgive ... ? Moving Towards Freedom. Dublin: Blackrock, Co., Dublin: The Columba Press.

Lofland, John. 1996. Social Movement Organisations: Guide to Research on Insurgent Realities. New Brunswick: Transaction. Makwasha, Gift M. 2011. The Quest for God's Irregulars: The Legacy of Arthur Cripps and the Role of the Anglican Church in Nation Building in Zimbabwe Today. Missionalia, Southern African Journal of Missiology 39: 228-47.

Manyonganise, Molly. 2015. The Church, National Healing and Reconciliation in Zimbabwe: A Womanist perspective on Churches in Manicaland (CiM). Ph.D. dissertation, University of Pretoria, Pretoria, South Africa.

Mbiti, John S. 1969. African Religions and Philosophy. Nairobi: Nairobi East African Educational Publishers Ltd., pp. 108-9.

McLaughlin, Janice. 1996. On the Frontline: Catholic Missions in Zimbabwe's Liberation War. Harare: Baobab Books.

MDC Facebook Post. 2015. MDC Zimbabwe. Available online: https://www.facebook.com/zimbabwemdc (accessed on 14 March 2015).

Mkaronda, Nicholas. 2003. The Emerging Voices from Within the Church. In Prophetic Witness in Zimbabwe: Critical Voices in Times of Crisis. Edited by Jonah K. Gokova, Eric McCandles and Nicholas Mkaronda. Harare: Ecumenical Support Services, pp. 29-46.

Ndlovu-Gatsheni, Sabelo. 2008. Patriots, Puppets, Dissidents and the Politics of Inclusion and Exclusion in Contemporary Zimbabwe. Eastern Africa Social Science Research Review 24: 81-108. [CrossRef]

Nye, Joseph. 1990. Bound to Lead: The Changing Nature of American Power. New York: Basic Books.

Nye, Joseph. 2005. Soft Power: The Means to Success in World Politics. New York: Public Affairs.

Philpott, Daniel. 2006. Beyond Politics as Usual: Is Reconciliation Compatible with Liberalism? In The Politics of Past Evil. Edited by Daniel Philpott. Notre Dame: University of Notre Dame Press, pp. 11-44.

Porter, Norman. 2003. The Elusive Quest: Reconciliation in Northern Ireland. Belfast: Blackstaff Press.

Ruzivo, Munetsi. 2008. A Mapping of the Church Groups in Zimbabwe. In The Role of the Church in the Struggle for Democratic Change in Zimbabwe. Edited by Munetsi Ruzivo. Harare: Zimbabwe Institute, pp. 4-14.

Sachikonye, Lloyd M. 2011. Zimbabwe's Lost Decade: Politics, Development E Society. Harare: Weaver Press.

Saunders, Rebecca. 2011. Questionable Associations: The Role of Forgiveness in Transitional Justice. International Journal of Transitional Justice 5: 119-41. [CrossRef]

Shore, Megan K. 2012. Christianity and South Africa's Truth and Reconciliation Commission. In Ashgate Research Companion on Religion and Conflict Resolution. Edited by Lee Marsden. Farnham: Ashgate, pp. 279-96.

Tarusarira, Joram. 2016. Reconciliation and Religio-Political Non-Conformism in Zimbabwe. London: Routledge.

Tarusarira, Joram. 2019. The Anatomy of Apology and Forgiveness: Towards Transformative Apology and Forgiveness. International Journal of Transitional Justice 13: 206-24. [CrossRef]

Tibaijuka, Anna Kajumulo. 2005. Report of the Fact-Finding Mission to Zimbabwe to assess the Scope and Impact of Operation Murambatsvina. UN Special Envoy on Human Settlements Issues in Zimbabwe. New York: United Nations.

Togarasei, Lovemore, and Ezra Chitando. 2011. "Be therefore Reconciled to one Another": E Church's Role in Justice, Healing and Reconciliation in Zimbabwe. Missionalia, Southern African Journal of Missiology 39: 210-27.

Tutu, Desmond. 1999. No Future without Forgiveness. New York: Doubleday.

U.S. Department of State. 2018. Zimbabwe 2018. International Freedom Report. Available online: https: //www.state.gov/wp-content/uploads/2019/01/Zimbabwe-2.pdf (accessed on 9 May 2020).

Waziweyi, Abel. 2011. An Investigation of the Role Played by Churches in Manicaland in Healing and Reconciliation in Zimbabwe 2000-2010. Unpublished Master's dissertation, Africa University, Mutare, Zimbabwe. 
Wolterstorff, Nicholas. 1983. Until Justice and Peace Embrace. Grand Rapids: Eerdmans.

Zehr, Howard. 2005. Changing Lenses: A New Focus for Crime and Justice, 3rd ed. Scottdale: Herald Press.

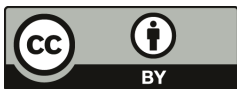

(C) 2020 by the author. Licensee MDPI, Basel, Switzerland. This article is an open access article distributed under the terms and conditions of the Creative Commons Attribution (CC BY) license (http://creativecommons.org/licenses/by/4.0/). 
Article

\title{
'Go and Prophesy in Your Own Land': Foreign Prophets and Popularism in South Africa. Evoking the Need of Jonathanic Theology for Peaceful Resolution of Difference
}

\author{
Bekithemba Dube \\ Education, University of the Free State, QwaQwa 9866, South Africa; bekithembadube13@gmail.com \\ Received: 14 November 2019; Accepted: 13 December 2019; Published: 13 January 2020
}

\begin{abstract}
Informed by a decoloniality lens and referencing motifs such as coloniality of power, knowledge, and being, this theoretical article analyses and problematises conflict, and reconstructs the experience of foreign and local prophets in South Africa. There is growing tension between foreign pastors and local pastors, with the former seemingly being popular because of performing 'miracles,' huge followings, and, in some cases, through mafia tendencies, which ignite the notion that expelling them from South Africa can be a counter-hegemony strategy to deal with popularism and criminality. The articles respond to two questions in this article: What factors influence conflict between migrant and local prophets? and, how can the story of David and Jonathan be used as a starting point for collective engagement in a process to achieve peace and healing? The article ends with arguing that the Jonathanic theology of peace, if pursued by migrant and local prophetic movements in South Africa, can reconstruct the prophetic terrain and assist in facilitating a rehumanising process, in addition to enacting the ontological density that has been lost. The article ends by arguing that Jonathanic theology is doable and desirable as a sustainable solution for religious conflict in South Africa.
\end{abstract}

Keywords: Jonathanic theology; migrant prophets; legislation; peace and decoloniality

\section{Introduction}

The prophetic terrain in the South African space has entered exciting, yet disturbing, times (Dube et al. 2017). It is interesting, because innovations are emerging in the prophetic space, which we, or, at least, people with an orthodox or conventional theological orientation, would not have imagined. It is disturbing, because prophetic movements have evoked wars through their prophets, based on nationality, popularity, and, in some cases, jealousy. The tension between local and foreign prophets is described best by Vorster (2017), who says the tension is between 'us,' clothed in a cloud of uniqueness, and 'them,' clothed in a cloud of otherness. Demarcation is followed by idolising the 'us' and demonising the 'them.' This article refers to various research studies that have been conducted on prophetic movements in South Africa.

My article is placed against the background provided by various studies that have been conducted on contemporary prophets in South Africa. However, no study has focused on the conflict between local and foreign prophets. An important study was done by Magezi and Banda (2017), who argue that the rise of Christian ministerial practices that emphasise wealth and prosperity ultimately raises questions about the appropriateness of using church ministry and theological education as instruments for economic survival. They note, furthermore, that Africa continues to see an increase in wealthy church pastors and prophets who preach the gospel of material prosperity. They conclude their research by arguing that there is a need to instill an ecclesiology that decommodifies the church and instills within Christian ministers the idea that, even though they can expect to survive financially through 
their churches, they must be accountable to the churches they lead. Kgatle (2018) conducted a study on contemporary prophets in South Africa, and argues that the prophetic voice addresses injustices in society. While this may be true, to an extent, the prophetic voice as demonstrated by some ministries is cause for concern, due to their mafia tendencies and their disregard for social justice-an example is Seven Angels Ministry (Dube 2019). Mafia tendencies as used in this article refer to criminality elements hidden within or in religious praxis and discourses that undermine the beauty of religion in society. Various examples of mafia tendencies will be referred to in this article as it unfolds, since it is one of the reasons for the conflict between local and foreign prophets in South Africa (Evans 2019; Collinson 2017; The Commission for the Promotion and Protection of the Rights of Cultural, Religious and Linguistic Communities Right (CRL Rights Commission 2017); Montsho 2019; Matangira 2019; Lindeque 2019; TimesLIVE 2019).

Another study was conducted by Pondani (2019), who argues that there has been an increase in prophets who apply dangerous so-called healing practices, such as eating snakes, drinking petrol, and the popular spraying of Doom (an aerosol insecticide), which endangers the lives of congregants who are desperate for that special miraculous touch. He concludes by arguing that there is a pressing need for religious communities, governments, and organisations to guard against abusive tendencies disguised as healing, and power.

After considering recent research in this area, there is realisation that none of the article focus is on the conflict between local and foreign prophets, or had a thrust to tease and unmute discourses in South Africa, and evoke the need for prophets to be agents of change and peace. Thus, the article is unique, because of its approach to the conflict between local and foreign prophets, which originates from the three decoloniality motifs of coloniality of power, knowledge, and being. My aim is to reinvent a new prophetic order and ways of thinking - to think anew, beyond modernity and the neoliberal approach to faith praxis in South Africa. It is also unique in that it problematises practices deemed to be a source of conflict and, finally, suggests how various tenets of the Jonathanic theology can promote coexistence and peace among the various prophetic movements in South Africa.

\section{Elaboration of the Problem}

Conflict is not limited to the prophets, but has escalated to include the media, judiciary system, politicians, and the general populace. The attitudes of citizens toward foreign prophets are clear from a petition with almost 5900 signatories quoted by Sain (2018): "As the citizens of South Africa we stand together in one voice requesting our government to please close down all these foreign prophetic churches based in South Africa with immediate effect to avoid more victimisation of our citizens, whether sexually, financially, emotionally or otherwise, in the name of miracles. We request that our government regulate our churches, and monitor and evaluate their activities."

The reasons given for demanding that foreign prophetic churches are closed down is based on a rather simplistic understanding of the problems related to religion in postcolonial states. This is because even some local prophetic movements are involved in problematic practices, as Sain (2018) explains, practices which, naturally, also pose a threat to humanity. For example, the Seven Angels Ministry is a local ministry that has been involved in armed robbery, constitutional delinquency, and financial misappropriation (Dube 2019). Prophet Mnguni of End Times Disciples Ministries in Soshanguve, Pretoria, is well known for his act of feeding his followers snakes-which, he claims, turns into chocolate (Makhudu 2018). Furthermore, Prophet Light Monyeki of Grace Living Hope Ministries, also in Soshanguve, claims to have received a shocking revelation from Prophet Monyeki: drinking rat poison mixed with water is an act of "the power of God" (Makhudu 2018). The list of examples of both local and foreign prophets who have been caught on the wrong side of the law is endless. Nevertheless, the foreign prophets are victims of partial democracy-though the article does not say their acts of criminality are justified. My point is that crimes relating to prophetic acts are not limited to nationality, or race, but that all humanity is susceptible to crime, and that justice must be served to all, and not selectively. 
Close consideration of the conflict between local and foreign prophets described above led me to realise that the prophetic movement in South Africa is marred by violence (Ndabeni 2017; Evans 2018; Sun Reporter 2019). However, as noted by Sithole (2014, p. viii), this violence is not visible, but is hidden, and those who are affected by it seem to be incapacitated and unable to see, name, describe, or explain it. The violence is institutionalised, naturalised, and normalised in everyday existence. Therefore, Ndlovu-Gatsheni (2013a) warns Africans by saying, "What Africans must be vigilant against is the trap of ending up normalizing and universalizing coloniality as a natural state of the world. It must be unmasked, resisted and destroyed because it produced a world order that can only be sustained through a combination of violence, deceit, hypocrisy and lies."

In light of this tension between local prophets, citizens, and politicians, on the one hand, and foreign prophets, on the other, there is need for religious leaders who support social justice to be harbingers of peace and, to achieve peace, their narratives and praxis should entail and foster the feasibility of coexistence and peaceful resolution of differences. To achieve this goal, the article, that a rereading, in a decoloniality sense, of the story of David and Jonathan in the context of conflict can serve as terrain that can be pursued to mitigate trajectories and ambivalence between and among local and foreign prophets in South Africa, could contribute to the construction of sustainable peace. While the task may appear difficult, especially in the context of conflict, it is doable, desirable, and inevitable. Sithole (2014) is of the view that there is a need to keep on thinking, even to the point of exhaustion, to avoid coloniality of mind, conflict and dehumanisation of anyone in society.

The following section discusses the theory underpinning this article, which is decoloniality.

\section{Theoretical Framework: Decoloniality}

The article is couched in decoloniality theory. The theory has roots in Latin America with leading scholars like Walter Mignolo, Maldonado-Torres, Quijon, Dussel (Wanderley and Barros 2018) and championed by Sabelo Gatsheni Ndlovu in South Africa. It was "born out of a realisation that ours is an asymmetrical world order that is sustained not only by colonial matrices of power but also by pedagogies and epistemologies of equilibrium that continue to produce alienated Africans" (Ndlovu-Gatsheni 2013b, p. 11), who, in turn, hate, colonise, and oppress other Africans. In its broader perspective, the theory represents a commitment to challenging and reformulating the communicational scientific discourse, from a criticism of the mediating power of the Eurocentric hegemonic thinking, to a native cultural paradigm (Eliana Herrera and Del Valle Rojas 2016, p. 78). It does so through a deliberate attempt to break with monologic modernity, and issuing an invitation to engage in dialogue (Maldonado-Torres 2011, p. 261). It is, furthermore, a theory that rejects modernity, which is located on the oppressed and exploited side of the colonial difference, in favour of a decolonial liberation struggle to achieve a world beyond Eurocentric ${ }^{1}$ modernity (Grosfoguel 2011, p. 21), dehumanisation, and all acts that seek to reduce people's ontological density. The theory questions the legitimacy and sanity of celebrating postcolonial thinking, while the majority of Africans remain mentally colonised (Kaunda 2015 , p. 77). The theory was chosen to inform the thinking of this article since one of the theory's primary mandates is to work towards a vision of human life that is not dependent upon or structured by the forced imposition of one ideal of society on those that differ in ideas (Mignolo 2007). The theory is appropriate in the South African contexts since it engages in a struggle against the Eurocentric design strategy [to colonise African continent], which is visible in religion informed by binarism and hierarchisation, and which keeps power imbalances and the colonial legacy intact (Sithole 2014).

It may be interesting to the reader that, in this article, decoloniality is not used to promote a struggle to decentre the Global North against Global South, as much of decoloniality research does. This article focuses on the Global South versus Global South actors, who, by default or by design, have

1 Eurocentric is a general term used in this paper to refer to what is referred to as West, or Global North, and, more precisely, the African colonisers, whose impact is still felt today, despite 26 years of South African independence. 
replaced Global North colonial masters, and have occupied the big brother mentality of determining what is right and wrong, while at the same time ignoring justice and equity within the prophetic space. To this end, the article agrees with Ndlovu-Gatsheni (2013b, p. 11), who centers around the perspective that the struggle of decoloniality is a "melee against invisible vampirism of imperialism technologies and colonial matrices of power (coloniality) that continue to exist in the minds, lives, languages, dreams, imaginations, and epistemologies of modern subjects in Africa and the entire global South."

As indicated above, the article will consider the three motifs of decoloniality, namely, coloniality of power, knowledge, and critique. The article defines coloniality. Coloniality refers to long-standing patterns of power that emerged as a result of colonialism, but that define culture, labour, intersubjective relations, and knowledge production well beyond the strict limits of colonial administrations. Thus, coloniality survives colonialism (Maldonado-Torres 2011). Coloniality is a name for the 'darker side' of modernity, which needs to be unmasked because it exists as "an embedded logic that enforces control, domination, and exploitation" (Mignolo 1995). Coloniality of power is a useful concept that delves deep into the roots of the present asymmetrical global power relations, and the way the present modern world order was constituted. It boldly enables a correct naming of the current 'global political present,' as a racially hierarchised, Eurocentric, Christian-centric, patriarchal, sexist, capitalist, heteronormative, hegemonic, and modern power structure (Ndlovu-Gatsheni 2013b). Coloniality of power describes modern global power as a network of relations of exploitation, domination, and control of labour, nature and its productive resources, gender and its reproductive species, subjectivity and its material and intersubjective products, and knowledge and authority (Quiano 2007). The coloniality of knowledge poses epistemological questions that are linked to: (a) the politics of knowledge generation; (b) questions of who generates which knowledge and for what purpose; (c) the question of relevance and irrelevance of knowledge; and, (d) how some knowledges disempower/empower communities and peoples (Ake 1982; Ndlovu-Gatsheni 2013a). The article refers to coloniality of knowledge in this article mainly because prophetic movements appear to tussle and compete on issues relating to who has better and more attractive religious knowledge, in order to gain popularity. Coloniality of being is defined by Maldonado-Torres (2011) as the combination of coloniality of power and coloniality of knowledge. Furthermore, coloniality of being is that of racial invention, where the notion of race and nationality is used as the organising principle through combining power and knowledge (Sithole 2014). To this end, there exists the notion that people who are not citizens of a certain country do not belong to its zone of being; thus, they should be subjected to dehumanisation, xenophobia, and other acts that reduce their ontological density. This mentality must be challenged. In essence, the article combines these three motifs, which are pertinent and relevant to the South African context marred with coloniality manifested in many ways, in which one of them is religion.

\section{Factors that Influence Prophetic Conflict in South Africa}

In this section, the article responds to the first question, namely, what are the factors propelling prophetic conflict in South Africa? Responding to this question will expose the readers to the challenge of prophetic conflict in South Africa. In doing so, the article intends to show the need for a Jonathanic theology, which is explained in greater depth when in response to the second question. Various factors are discussed, the first one being popularism.

Prophetic movements in South Africa have been marred by competition, which, in some cases, has gone beyond control, and has led to conflict. Religious adherents or believers move from one prophetic movement to the next, following popular prophets. Arguably, prophetic movements are the fastest growing religious movements in South Africa. While precise statistics are lacking, scholars agree that prosperity gospel followers rival, if not exceed, the numbers of followers of mainstream religions (Van Wyk 2019). This claim implies that some churches or religious groups continue to lose members to big and popular prophetic organisations. Followers of prophetic movements are not captive victims of so-called cult leaders. In fact, they move constantly between churches in search of more 
efficacious "technologies" and "stronger prophets" (Van Wyk 2019). Magezi and Banda (2017) believe that the popularism sought by some contemporary prophets is a sign of them actually competing with Christ- they often project themselves as uniquely anointed by God. There is a silent force among prophets in South Africa, who are on a quest of gaining power through teaching, prophecies, and other actions. Some have required adherents eat snakes, drink diesel, be sprayed with Doom—all to gain power, which, in turn, translates into popularism. The desire for power has forced some prophets to resort to unconventional practices. In some cases, the prophets become, as suggested by Henze (1996, p. 1), legalistic and mind controlling, and they exhibit authoritarian tendencies. Cognisant of these practices, the media, politicians, prophets, and the general populace that were attracted became involved in conflict between those who practice and support what others believe to be malpractices, and those who believe that their mandate is to be harbingers of truth and the pure gospel.

Most foreign prophets have been accused of using faith to extort money from people (CRL Rights Commission 2017). In fact, during hearings of the Commission, some pastors or prophets demonstrated their resistance to the Commission by refusing to take the prescribed oath, refusing to submit the required financial documents and bank statements, and causing dramatic scenes (CRL Rights Commission 2017, p. 17). Some prophets were accused of money laundering, such as Shephard Bushiri (Lindeque 2019; TimesLIVE 2019; Evans 2019), and Pastor Alph Lukau (Montsho 2019; Matangira 2019)—both foreign nationals who operate churches in South Africa. However, according to the CRL Commission report, there are many local religious groups in South Africa who are also deemed to be "profiteering from religion," especially through their refusal to submit their financial records to the CRL commission; these include Pastor Mboro and Prophet Hadebe (CRL Rights Commission 2017). In commenting on prophet Hadebe, Collinson (2017) reports that Hadebe refused to appear before the Commission and ignored its request to view his church's financial statements.

Shepherd Bushiri, a well-known leader who had been accused of prophetpreneurship, is a Malawian who was arrested in 2018 on allegations of fraud and money laundering, among other crimes. Bushiri, in response to allegations of commercialising religion, said, "I am a businessman and that is separate from being a prophet. My prosperity is from private businesses. Such questions are not asked from leaders of white churches but when an African man prospers, then it's a problem" (Fihlani 2018).

While the article does not seek to either exonerate or condemn Bushiri, the article submits that, in South Africa, there is the idea that, when one race or nationality does something, like extort believers, it is wrong, and when it is done by another race or nationality, it becomes right. The point, which relates to the source of conflict, is that prophetic movements in South Africa, whether local or foreign, are characterised by commercialisation of religion; however, the outcry becomes louder when the movement involved has foreign origins.

The article has attempted to show that both local and foreign prophets (not only those mentioned) have been accused of profiteering, which, if it is proven to be true, means that prophetic movements must re-examine their relevance in the context of promoting social justice and social transformation. With reference to decoloniality, commercialisation of the gospel is accompanied by power, and this power makes the holder great. I, thus, problematise the commercialisation of the gospel, especially when it is used to subject the poor to even worse poverty, and to dehumanise people through criminal acts that extort money from them. Societies cannot prosper in the context of exploitation, especially by religious leaders, who are supposed to be the moral agents of change. So, in decoloniality, exploitation, whether by local or foreign prophets, must be challenged, and religious misconduct and delinquency must be prosecuted and judged — not based on race, nationality or colour-as these acts remove some people from the zone of being.

In an attempt to gain popularity, prophets have resorted to performing miracles; however, some of these miracles are questionable. One 'miracle' that became problematic was performed by Pastor Alph Lukau, and resulted in an intensification of the call for foreign prophets to return to their own countries and perform miracles for their own people (Matangira 2019; Montsho 2019). A local prophet 
who seemed agitated by this miracle was Prophet Paseka 'Mboro' Motsoeneng, founder of Incredible Happenings Ministries. In responding to Lukau's so-called miracle, Jordaan (2019) cites Mboro saying, "They say I am jealous. What jealous. I gave away cars, houses. There is no competition here. I'm here because the name of Christ has been played with. This miracle is a fraud and if it's not, they must bring proof. Let's talk about it as men of God. That man never died. God will heal people when he wants, in any way he wants. Let's not fake things."

In addition, Lukau's miracle attracted the attention of Bishop Elly Mogodiri of St. Oaks Global Church of Christ, who is cited by Njilo (2019) as commenting that, "I am aware and have been duly advised that this case falls within the ambit of organised crime, fraud and misrepresentation, among other misdemeanours. As a result, I have since approached my local police station, being Hartbeespoort SAPS in the North West province, and opened an organised crime case."

It is clear from this discussion that 'fake miracles' are one of the ways in which prophets gain popularity, and also a source of conflict among the prophetic movements. From a decoloniality lens, this phenomenon refers to coloniality of power, which transfers the prophets who are deemed powerful to the zone of special being, while those prophets who cannot perform such miracles are moved from the zone of being. Decoloniality evokes the need to challenge acts and narratives that enhance people's ontological density at the expense of made-up miracles.

Criminality or mafia-based tendencies that are hidden in religious narratives are one of the common issues that haunt the prophetic movement in South Africa, and serve as a cause of conflict. Kgatle (2017) describes criminal or mafia groups as "churches [that] are known for their refusal to affiliate with established denominations in South Africa. Some of these churches also refuse to be part of the South African Council of Churches (SACC)." In most cases, these mafia churches strive, as suggested by Damiani (2002, p. 45), by "destroying any individual personality and replace the void with a cultic personality that no longer questions, thinks critically, or feels the impact of an abusive system." In most cases, this type of criminality is not visible, but is hidden from religious adherents. It causes those who are subjected to it to become incapacitated, and to see, name, describe, and explain it as it is institutionalised, naturalised, and normalised (Sithole 2014). The article agrees with the observation by Magezi and Banda (2017), that, under normal circumstances, prophets are conduits through which God's authority is extended to the believer. Sadly, this creates opportunities for prophets to abuse their followers, because the leaders are feared and considered as beyond questioning (Magezi and Banda 2017).

The list of criminality and mafia tendencies exhibited by both local and foreign prophets is long. For example, Timothy Omotoso is known for rape scandals, money laundering, and human trafficking (Dube et al. 2017); the Seven Angels Ministry for constitutional delinquency, abuse of resources and preventing children from attending school (Dube 2019). In some cases, congregants have to ingest or are sprayed with dangerous poisons, ostensibly as part of a healing process (Jamaica Observer 2016). As long as religious leaders are guilty of such practices, religions will continue to remain a problematic institution in society, and, even worse, create competition which accelerates to conflict. Thus, Kaunda (2015, p. 75) warns that, "as long as African mind remains one of the spaces for oppressive religious structures there seems to be no possibility of academy and knowledge decolonization and consequently, no social transformation, no political progress and no economic development."

In light of these factors, evil or otherwise, the article submits that religious leaders should remain agents for peace, social justice, and accountability, through peaceful resolution of difference, and dialogue as a benchmark that society can follow. The continued conflict, the article submits, is a "darker side" of modernity that needs to be unmasked (Mignolo 2000), because it exists as an embedded logic that enforces control, domination, and exploitation disguised in the language of salvation, progress, and modernisation (Ndlovu-Gatsheni 2013b, p. 13), and protection of citizens from foreign prophets. Cognisant of this, the article suggested the tenets of Jonathanic theology for framing a space for peaceful resolution of the conflict between local and foreign prophets. 


\section{Jonathanic Theology: What Does It Entail and What Opportunities Does It Offer?}

This section responds to the second research question and discusses the themes that have been raised. Jonathanic theology is a term that was coined for the sake of this article, and for future discussions. It should not be confused with the theology propounded by Jonathan Edwards. Rather, it is framed within the story of Jonathan and David (I Samuel 18-20), a biblical passage which intends to evoke a new reading of and thinking on. The article does not intend to use the passage, like many scholars have done, to justify homosexuality or lesbianism, or to read the passage in the context of biblical wars caused by tussles for a throne. There is an attempt to reread the texts anew, informed by Ndlovu-Gatsheni's (2013a) argument that decoloniality emphasises an agenda that involves rethinking the very constitution of the present and the construction and reconstruction of new identities and philosophies. The attempt is to use the text of 1 Samuel 18-20 to tease a new theology of prophetic defence, peace, and peaceful resolution of difference in the context of ambivalence of the prophetic terrain, marked by dislodging prophetic movements with different ideas from one's own. The article wishes to emphasise that prophetic vocation can survive in the contexts of collective effort to defend oppression, racism, and inequality that arise from bolding a different theological stance. The article provides a reread and reinterpreting of 1 Samuel 18-20 informed by a decoloniality lens, especially its motifs of coloniality of power, knowledge, and being. By doing so, the theology embedded within the text will evoke a philosophy of liberation, which entails rehumanisation of the dehumanised, and the courage to care and to love (Mpofu 2017, p. 4).

\subsection{Tenets of the Jonathanic Covenant in 1 Samuel 18-20}

This section unpacks various tenets emanating from the story of David and Jonathan. For the purposes of grounding readers on how the conceptualization of Jonathanic theology came about, the article briefly highlights the story. The story of Jonathan and David is taken from the Bible and, in particular, from 1 Samuel 18-20. Saul was the king of Israel; however, his popularity was diminishing while David was getting a spotlight among the Israelites. Saul was not pleased with David's popularism and sought to kill him. Jonathan was Saul's son and a friend to David. In the context of Saul's attack on David, Jonathan stood to protect David against his father Saul. Jonathan made a covenant with David to ensure that David was protected from Saul and, likewise, David was to remember the family of Jonathan when he ascended to the throne, which he did with Mephibosheth in 2 Samuel 9. The bottom line of the story is a commitment of Jonathan to promote peace in the context of political and religious contexts, which made me reread the story and see its applicability in the prophetic movements in South Africa, to tease new meanings of the story and debates in the field of religion, politics, and peace towards contributing to a better future for all.

While Jonathan and David were not prophets, the principles within the story can be applied into the South African prophetic space. Referring to it as Jonathanic theology does not seek to undermine the role played by David in this story, it is not the case; the article refers to Jonathanic theology because it was Jonathan who took the initiative to protect, defend, and make peace with David in the face of Saul's brutality towards David. Jonathan's actions can make up a theology on its own, especially with reference to his defence of David, and his attempts to make peace with David, regardless of Jonathan being a potential heir to the throne should David be deposed. The approach is relevant and serves as a reminder, as postulated by Abbink (2014, p. 89), that religious leaders are not only community leaders and preachers, but also moral authorities who play mediating roles in solving local conflicts-also between people of different faiths or denominations-and they should not be promoting violence and hatred of people of difference. To this end, the article identified four tenets that define Jonathanic theology for peaceful resolution of difference, namely, brotherly love greater than the throne, defence for the afflicted in society, sincerity to power, and commitment to purpose. Below, informed by decoloniality motifs, these tenets will be discussed in detail. 


\subsubsection{Brotherly Love Greater Than the Throne}

According to the Israelite tradition, it was a norm that, after the death of Saul, Jonathan would inherit the throne of his father. However, Jonathan was cognisant of David's capabilities, and that David would be a better king than he would be. Jonathan understood that the throne could be sacrificed for brotherly love.

The articles consider this to be a very important attitude, one that can evoke peace between local and foreign prophetic ministries. Instead of working with people who have ulterior motives, and who are against either local or foreign prophets, we should tap into Jonathan's attitude to handle contemporary issues. Unfortunately, most prophets in South Africa, whether local or foreign, are obsessed by being powerful, popular, and feared, at the expense of cultivating peace in the context of conflict. It should not be understood as saying that it is not ideal or noble for a prophet to be great and influential. However, greatness should not exist at the expense of peace and brotherly love. This attitude is in line with decoloniality thinking, which promotes expansion of people's ontological density that has been shuttered by social injustice, inequality, and hate.

\subsubsection{Defence for the Afflicted in Society}

Faith traditions, from time immemorial, have always dealt with issues affecting the Christian faith privately. The elders took upon themselves the task to protect innocent members of society, while at the same time following a laid-down procedure for disciplining delinquent faith members without attracting public attention-unlike what is currently the way in the South African space. Unfortunately, some prophets, media, and politicians have been used as silencing tools to degrade certain prophets, especially those who are foreign nationals. In essence, the prophetic conflict is often hijacked by politicians and used to push other agendas. To shed light on this, Montsho (2019) cites Wilfrid Napier, a leader of KwaZulu-Natal church leaders, who spoke on behalf of his organisation when he said that, "we are most seriously concerned that some of the political leaders are responsible for this violence by their derogatory and inflammatory statements about migrants, refugees, asylum seekers, and other vulnerable persons." To this end, the article supports Napier's stance; it shows care and the need for justice for everyone, regardless of nationality. The article submits that defending the defenceless, as a core value of a religion such as Christianity, is a viable way to end conflict.

While the media and the public have the right to express anger about foreign prophets who have mafia tendencies, it only becomes, unfortunately, when prophets, without following a biblical procedure given in 1 Corinthians 6 , team up with the media and the public to displace prophets of difference.

Rereading the Jonathan and David narratives paints a new picture of how leaders must behave when they face conflict. When it became clear to Jonathan that David was hated for being popular, Jonathan did not join forces with his father to destroy David, but instead, defended David with all his might. To Jonathan, defending the less privileged in society is a faith mandate, which must be pursued by all in society who love peace, justice, and fairness. Prophets should lead by example in this regard. This approach to resolving conflict supports decoloniality thinking, since this approach helps a new and better life to be reimagined for all and brings dehumanised people back to the zone of being.

\subsubsection{Speaking Truth to Power}

The concept of speaking truth to power can be traced to the works of Quakers and Gandhian ethics (Dordfarm 2013; Merryn 2008). It was a nonviolent approach to resolving conflict (Szenkovics 2013). The concept is borrowed in this article to evoke the need of peace and it relates well with the story of David and Jonathan. Peace begins with truth and, without truth, meaningful peace cannot be achieved. The article is aware that the word sincerity is relative and problematic, especially within postmodern and neoliberal thinking. Therefore, the desire is that sincerity is understood as collective engagement and dialogue, which challenges mafia and criminal tendencies in religious organisations in South 
Africa. It is unfortunate that many popular prophets in South Africa are, by nature, untouchable; they cannot be called to accountability, and their ways are the Alpha and Omega of the gospel.

The article problematises this approach to power, because it becomes a source of abuse and a national threat. Decoloniality challenges the coloniality of power that is unquestionable and untouchable, and evokes the need to challenge such practices as a prerequisite for promoting peace and coexistence. Jonathan, in the midst of the conflict between David and Saul, was able to be sincere and challenge Saul's injustice against David. To Jonathan, sincerity was pivotal even though it was not fashionable within his household; thus, through Jonathan's actions, a conclusion can be drawn that sincerity matters even in the context of conflict. Thus, based on the foregoing argument, peace, even in the context of conflict, is important and should be pursued at all costs.

\subsubsection{Commitment to Purpose}

A Jonathanic theology reminds me that, in the context of conflict, prophets, as long called by God, must remain committed to the purpose of their vocation. This commitment involves devoting energy to social transformation, and not in engaging in battles. David, in the context of conflict, remained committed to his purpose and was not distracted to engage in fightbacks with Saul. Jonathanic theology reminds us that greatness cannot be achieved if most of our energy is invested in conflict, instead, we should stay on purpose. Local and foreign prophets can learn much by staying on purpose, despite the pressure and the need for power, and the financial rewards that come with power. Jonathan understood his purpose, even though it meant that David would be greater than he would be; Jonathan was prepared to let go of power and pursue purpose.

The article ends by submitting that peace must be greater than the need for power and knowledge, and embrace a realisation that all people, regardless of nationality, are entitled to live peaceful lives, and that their ontological density must be respected. Through this approach, all humankind can be brought into the zone of being. Religious groups should be harbingers of this noble, desirable, and doable idea of promoting peace. While this may not be an easy task, Desmond Tutu ${ }^{2}$ (2007) encouraged all who sought peace by saying "You dream that yes it is possible for there to be no war any longer. You dream of a world where poverty will be history. You dream of a world where there will be laughter and compassion and caring and gentleness, then continue" not only dreaming but continuing to tease, and challenge structures and narratives that create conflict as opposed to peace as in the scenario discussed in this article

\section{Conclusions}

This article discussed the factors that propel conflict between local and foreign prophets in South Africa. This article highlighted various trajectories that threaten the role of religious leaders as agents that should be promoting peace in society, that religious leaders should be harbingers of social transformation, and that issues such as jealousy, competition, criminality, and mafia tendencies undermine leaders' roles in society. Using three decoloniality motifs, the article problematised the conflict between local and foreign prophets. The tenets of Jonathanic theology were presented, which emanates from the interaction between David and Jonathan during David's conflict with Saul. The article concluded that peace requires effort and that religious leaders, through their practices, narratives, and discourses, must model peace. Even in cases of evident violation of prophetic vocation, procedures that are laid down must be followed without subjecting individuals to dehumanising experiences by dealing with conflict through the media or public embarrassment.

Funding: This research received no external funding.

2 Tutu, Desmond, Mpilo. 2007. Gandhi Lecture on 21 September 2007 at the JMU Convocation Center, Harrisonburg, Virginia. He was introduced by Professor Sushil Mittal, Director of the Mahatma Gandhi Center for Global Nonviolence at James Madison University. 
Conflicts of Interest: The author declares no conflict of interest.

\section{References}

Abbink, Jon. 2014. Religion and politics in Africa: The future of "the secular". Africa Spectrum 49: 83-106. [CrossRef]

Ake, Claude. 1982. Social Science as Imperialism: The Theory of Political Development. Ibadan: Ibadan University Press.

Collinson, Carl. 2017. State Is Trying to Control Religion and Doesn't Listen to Us. Available online: https: //mg.co.za/article/2017-08-30-state-is-trying-to-control-religion-and-doesnt-listen-to-us/ (accessed on 12 October 2019).

CRL Rights Commission. 2017. CRL Rights Commission Report: Commercialisation of Religion E Abuse of People's Belief Systems; Report on the Hearings on the Commercialisation of Religion and Abuse of People's Beliefs Systems. Pretoria: Department of Cooperative Governance and Traditional Affairs.

Damiani, Rich. 2002. Spiritual abuse within the church. its damage and recovery process. Evanel 20: 42-48.

Dordfarm, Ariel. 2013. Speaking Truth to Power. A Toolkit for Action to Create Change in the Classroom and Beyond. New York: Robert F Kennedy Human Rights.

Dube, Bekithemba. 2019. Conundrum of religious mafia and legislation in South Africa: When does religion become a national threat? Reference to the Seven Angels Ministry. Verbum et Ecclesia 40. [CrossRef]

Dube, Bekithemba, Milton Molebatsi Nkoane, and Dipane Hlalele. 2017. The ambivalence of freedom of religion, and unearthing the unlearnt lessons of religious freedom from the Jonestown incident: A decoloniality approach. Journal for the Study of Religion 30: 330-49. [CrossRef]

Evans, Jenni. 2018. Ngcobo Massacre: Mbalula Brands Shoot-Out Church "Satanic". Available online: https://m.news24.com/SouthAfrica/News/ngcobo-massacre-mbalula-brands-shoot-out-churchsatanic-20180224 (accessed on 17 September 2019).

Evans, Sarah. 2019. Sanco: Bushiri Lawyers Xenophobia Accusations an Attempt to Shift the Blame. Available online: https://m.news24.com/SouthAfrica/News/sanco-bushiri-lawyers-xenophobia-accusationsan-attempt-to-shift-the-blame-20190106 (accessed on 22 September 2019).

Fihlani, Pumza. 2018. Meeting the Man Who Says He Can Walk on Air. Available online: https://www.bbc.com/ news/world-africa-43245126 (accessed on 19 October 2019).

Grosfoguel, Ramón. 2011. Decolonizing Post-Colonial Studies and Paradigms of Political-economy: Transmodernity, Decolonial Thinking, and Global Coloniality. Available online: https://escholarship. org/uc/item/21k6t3fq (accessed on 11 August 2019).

Henze, Donald. 1996. Spiritual Abuse. London: Watchman Fellowship International.

Eliana Herrera, Francisco Sierra Caballero, and Carlos Del Valle Rojas. 2016. Towards an Epistemology of the South . Decoloniality, Informative Knowledge Power and the New Latin-American Community. Chasqui: Latioamericana de Comunicacion.

Jamaica Observer. 2016. South African Prophet Sprays Followers with Insect Killer. Available online: http: //www.jamaicaobserver.com/news/South-African--prophet--sprays-followers-with-insect-killer (accessed on 22 October 2019).

Jordaan, Nomahlubi. 2019. Let's Not Fake Things, Pastor Mboro Implores Pastor Alph Lukau. Available online: https://www.sowetanlive.co.za/news/south-africa/2019-02-28-lets-not-fake-things-pastor-mboroimplores-pastor-alph-lukau/ (accessed on 10 September 2019).

Kaunda, Chammah. 2015. The denial of African agency: A decolonial theological turn. Black Theology 13: 73-92. [CrossRef]

Kgatle, Mookgo S. 2017. The unusual practices within some neo-pentecostal churches in South Africa: Reflections and recommendations. HTS Teologiese Studies/Theological Studies 73: 8. [CrossRef]

Kgatle, Mookgo S. 2018. The prophetic voice of the South African Council of Churches: A weak voice in post-1994 South Africa. HTS Teologiese Studies/Theological Studies 74: 8. [CrossRef]

Lindeque, Mia. 2019. Bushiri \& Wife Back in Court for Money Laundering Trial. Available online: https://ewn.co. za/2019/08/29/bushiri-and-wife-back-in-court-for-money-laundering-trial (accessed on 10 October 2019).

Magezi, Vhumani, and Collium Banda. 2017. Christian ministry and theological education as instruments for economic survival in Africa. HTS Theological Studies/Theological Studies 73: 1-9. [CrossRef] 
Makhudu, Tshegofatso. 2018. Five Religious Scandals That Rocked South Africa. Available online: https: //www.news24.com/SouthAfrica/News/five-religious-scandals-that-rocked-south-africa-20180125 (accessed on 12 September 2019).

Maldonado-Torres, Nelson. 2011. Thinking through the decolonial turn: Post-continental interventions in theory, philosophy, and critique-An Introduction. Transmodernity: Journal of Peripheral Cultural Production of the Luso-Hispanic World 1: 1-15.

Matangira, Lungelo. 2019. It's a Miracle: Cutting Edge Exposes Tricks Used to Con Churchgoers. Available online: https://ewn.co.za/2019/03/13/it-s-a-miracle-show-exposes-tricks-used-to-con-churchgoers (accessed on 12 September 2019).

Merryn, Erin. 2008. Speak Truth to Power. Human Rights Defenders Who Are Changing the World. New York: Robert F Kennedy Human Rights.

Mignolo, Walter D. 1995. The Darker Side of Renaissance. Literacy, territoriality, E Colonization, 2nd ed. University of Michigan Press: Ann Arbor.

Mignolo, Walter. 2000. Local Histories/Global Designs: Coloniality, Subaltern Knowledges, and Border Thinking. Princeton: Princeton University Press.

Mignolo, Walter D. 2007. Delinking: The rhetoric of modernity, the logic of coloniality and the grammar of de-coloniality. Cultural Studies 21: 449-514. [CrossRef]

Montsho, Molaole. 2019. Fraud Charges Laid Against "Resurrection" Pastor Alph Lukau. IOL News. February 26. Available online: https://www.iol.co.za/news/south-africa/north-west/fraud-charges-laidagainst-resurrection-pastor-alph-lukau-19523173 (accessed on 1 August 2019).

Mpofu, William. 2017. Decoloniality as Travelling Theory: Or What Decoloniality Is Not. Available online: https://wiser.wits.ac.za/content/decoloniality-travelling-theory-or-what-decoloniality-not-12918 (accessed on 22 September 2019).

Ndabeni, Khanyi. 2017. Insults, Death Threats for Bling Pastor's Critic. Available online: https://www. timeslive.co.za/sunday-times/news/2017-01-15-insults-death-threats-for-bling-pastors-critic/ (accessed on 15 October 2019).

Ndlovu-Gatsheni, Sabelo J. 2013a. Empire, Global Coloniality and African Subjectivity; New York: Berghahn Books, 1st ed. Available online: https://www.jstor.org/stable/j.ctt9qcvmf (accessed on 17 October 2019).

Ndlovu-Gatsheni, Sabelo J. 2013b. Why decoloniality in the 21st Century? The Thinker for Thought Leaders 2013: 10-16.

Njilo, Nonkululeko. 2019. Bishop Slams 'Pulpit Greed', Opens Criminal Case against Pastor Lukau. SowetanLIVE. February 26. Available online: https://www.sowetanlive.co.za/news/south-africa/2019-02-26-bishop-slamspulpit-greed-opens-criminal-case-against-pastor-lukau/ (accessed on 1 September 2019).

Pondani, Simbarashe. 2019. "Prophets of Doom": The Phenomenon of Healing and Power Dynamics in Neo-Pentecostal African Churches. Master's thesis, Stellenbosch University, Stellenbosch, South Africa. Available online: https://scholar.sun.ac.za:443/handle/10019.1/106082 (accessed on 12 September 2019).

Quiano, Aníbal. 2007. Coloniality and modernity or rationality. Cultural Studies 21: 168-78. [CrossRef]

Sain, Rashil. 2018. Petition Calls for Shutdown of Foreign Prophetic Churches in SA. Pretoria Newws. October 23. Available online: https://www.iol.co.za/pretoria-news/petition-calls-for-shutdown-of-foreign-propheticchurches-in-sa-17597255 (accessed on 18 August 2019).

Sithole, Tendayi. 2014. Achille Mbembe: Subject, Subjection, and Subjectivity. Ph.D. thesis, University of South Africa, Pretoria, South Africa. Available online: http://uir.unisa.ac.za/bitstream/handle/10500/14323/thesis_ sithole_t.pdf?sequence=1 (accessed on 17 September 2019).

Sun Reporter. 2019. Angry Residents Gather to Burn Bushiri's Church'. Daily Sun. January 5. Available online: https://www.dailysun.co.za/News/National/angry-residents-gather-to-burn-bushirischurch-20190105 (accessed on 19 October 2019).

Szenkovics, Dezso. 2013. The Relevance of Mahatma Gandhi's Philosophy for the 21st Century. Acta Universitatis Sapientiae, European and Regional Studies 4: 89-99.

TimesLIVE. 2019. Bushiri Money Laundering Case Brought forward Owing to "Security Matters": NPA. TimesLIVE. May 9. Available online: https://www.timeslive.co.za/news/south-africa/2019-05-09-bushirimoney-laundering-case-brought-forward-owing-to-security-matters-npa/ (accessed on 10 October 2019). 
Van Wyk, Ilana. 2019. Why “Money” Gospel Followers Aren't Simply Credulous Dupes. TimesLIVE. February 23. Available online: https:/www.timeslive.co.za/news/south-africa/2019-02-23-why-money-gospel-followersarent-simply-credulous-dupes/ (accessed on 11 October 2019).

Vorster, Koos. 2017. Racism in South Africa: Are we at a tipping point? In Togetherness in South Africa. Edited by Jacobus Abraham du Rand, Koos Vorster and Nico Vorster. Cape Town: Aosis Scholarly Books, pp. 59-78. [CrossRef]

Wanderley, Sergio, and Amos Barros. 2018. Decoloniality, geopolitics of knowledge and historic turn: Towards a Latin American agenda. Management and Organisational History 14: 79-97. [CrossRef]

(C) 2020 by the author. Licensee MDPI, Basel, Switzerland. This article is an open access article distributed under the terms and conditions of the Creative Commons Attribution (CC BY) license (http://creativecommons.org/licenses/by/4.0/). 
Article

\title{
Challenges of Countering Terrorist Recruitment in the Lake Chad Region: The Case of Boko Haram
}

\author{
Kangdim Dingji Maza *, Umut Koldas and Sait Aksit \\ Department of Political Science and International Relations, Near East University, Nicosia 99138, Cyprus; \\ umut.koldas@neu.edu.tr (U.K.); sait.aksit@neu.edu.tr (S.A.) \\ * Correspondence: mdingji@gmail.com
}

Received: 4 December 2019; Accepted: 16 February 2020; Published: 20 February 2020

\begin{abstract}
This article attempts to shed light on the challenges confronting relevant actors (state and non-state) in countering the threat of terrorism recruitment by focusing on the Boko Haram terrorist organization, whose presence and activities threaten the security of the Lake Chad region. The article uses a qualitative research technique combining key informant interviews with stakeholders familiar with the conflict, academic and non-academic documents, reports, and policy briefs. The findings of the article suggest that despite the various initiatives by stakeholders aimed at containing the strategies of recruitment, the group continues to expand its base by launching coordinated attacks that further destabilize the region. These challenges stem from a lack of a clear-cut counterterrorism strategy, a dearth in technological and mutual trust between actors and locals in the management and utilization of intelligence, and the inability of state institutions to 'coerce and convince' citizens in terms of its capacity to counter the danger of terrorism recruitment and expansion. The article, amongst other things, recommends a community policing model similar to the 'Nyumba-Kumi security initiative' adopted by most countries in East Africa for the effective assessment and detection of threat forces; the state and its agencies should show the capacity to coerce and convince in dealing with the (ideological, religious, social, and economic) conditions, drivers, and factors promoting the spread of terrorism as well as other forms of violent extremism in the society; furthermore, there is a need for stakeholders to adopt a comprehensive and holistic counterterrorism/violent extremism strategy to reflect present-day security challenges as well as to guarantee sustainable peace.
\end{abstract}

Keywords: Boko Haram; terrorist recruitment; counterterrorism; sustainable-peace; violent extremism; Nigeria; Lake Chad Region

\section{Introduction}

Countering the recruitment, expansion, and activities of terrorist organizations is one of the major challenges confronting actors in combating terrorism (Weeraratne 2017). This is because terrorism remains a major threat to the stability of the international system, given that its impacts whenever such attacks take place leave a long-lasting emotional, physical, and psychological trauma on the targets and victims (Bergesen and Lizardo 2004; Ranstorp 2006; Cannon and Iyekekpolo 2018). This assertion also relates to the Boko Haram ${ }^{1}$ terrorist group operating in the northeastern ${ }^{2}$ part of Nigeria and the Lake Chad Region in West Africa. ${ }^{3}$ Several studies have suggested that after the death of its founding leader,

1 Most studies on "Boko Haram" refer to it as the radical Islamic, Salafist, and Jihadist terrorist group which operates in northeast Nigeria and the Lake Chad region of West Africa. The group is driven by anti-Westernism, especially education, labelling it as forbidden. It aims to entrench an Islamic Caliphate in Nigeria and territories perceived to be under its sphere of influence in line with the principles and dictates of Sharia Law (Islamic Law).

2 In this article, the term is used to explain the five states of Adamawa, Bauchi, Borno, Gombe, Taraba, and Yobe in Nigeria. The Lake Chad region in this article refers to countries comprising Cameroun, Chad, Niger, and Nigeria. 
Mohammed Yusuf, in $2009^{4}$, the organization regrouped and resurfaced in 2010 and began carrying out a series of coordinated attacks on civilians, places of religious worship, as well as private, public, and state institutions (Maiangwa et al. 2012; Onuoha 2012; Oyewole 2015; Umukoro 2016; Tukur 2017; Felter 2018). These attacks ranged from suicide raids, kidnapping, to the use and deployment of improvised explosive devices (IEDs). The impact of these attacks led to over 100,000 documented deaths, the destruction of properties amounting to over nine billion US dollars, and the displacement of over 2,400,000 persons across the Lake Chad Basin. This has led to the group being regarded as one of the most dangerous terrorist organizations around the world (China Global Television Network 2017; Matfess 2017; Premium Times 2017a, 2017b; Institute for Economics and Peace 2015, 2017, 2018).

It should be noted that for terrorist organizations to stay relevant and operate effectively, the need for regular recruitment of members is an existential reality to ensure their survival (Ranstorp 2006). Campbell (2013), Zenn (2013a, 2013b), Voll (2015), and the UNODC (2017), highlighted four fundamental conditions most terrorist organizations employ to recruit members. These reasons include Financial Incentives to lure individuals affected by negative structural conditions such as poverty, unemployment, and poor welfare services as easy targets for terrorist organizations. The societal influence of Kinship, where individuals who are biologically and socially related with persons affiliated to terrorist organizations are conscripted by these groups. The long history of inter-religious and politically motivated violence influenced by the elites has not only divided most societies along religious lines, but has also created a level of mutual suspicion across the various religious divides, as witnessed in Nigeria, which makes it easy for groups such as Boko Haram to recruit members. The negative use of religion as a tool for radicalization and preaching of violent and extreme views by rogue clerics to indoctrinate individuals into these terrorist organizations. These reasons serve as the optics and framework most studies coalesce around when looking at the strategies used by violent extremist groups to recruit members (Combs 2017; Iyekekpolo 2018).

Although several studies have focused on terrorism and Boko Haram, the understanding of strategies used by terrorist organizations such as Boko Haram to recruit members remains largely under-researched. It is in this context that this article seeks to examine the strategies used by this group to recruit members and also the challenges confronting stakeholders in combating them. It adopts a qualitative research technique through the use of academic, non-academic documents, reports, and personal interviews in the form of key informant interviews (KIIs), with community and religious leaders, academic and policy experts, and individuals affected by the activities of Boko Haram. The article seeks to contribute to the growing literature on terrorist recruitment strategy, the role of actors and other relevant stakeholders ${ }^{5}$ in combating these strategies and the challenges confronting stakeholders in countering them. In this context, the article asks the following research questions: What are the various Boko Haram recruitment strategies? What are the measures taken by stakeholders to combat Boko Haram's recruitment strategy? What are the challenges confronting stakeholders in confronting them?

The article is structured and organized under the following sub-headings. Following the introduction, the second part of the article clearly outlines the methodology as well as the questions required by the key informants as it pertains Boko Haram recruitment strategies, the contributions by relevant actors in countering these strategies and also the challenges in combating Boko Haram recruitment strategies across Lake Chad. The third section, clarifies and theorizes the concept of terrorist recruitment, reviews the various studies on terrorist recruitment, the methods and strategies used by Boko Haram to recruit members. Measures taken by relevant stakeholders at the national, sub-regional, and regional levels to confront the recruitment and expansion of this terrorist organization forms the fourth part of the study. The fifth part of the article focuses on the challenges confronting actors in

\footnotetext{
Mohammed Yusuf, the defunct leader, died after a confrontation between the group and the Nigerian security forces The term actors or relevant stakeholders is used in this article to refer to states and other non-state actors such as sub-regional and regional groups including ECOWAS, LCBC, Civil Societies and Faith-Based Organizations.
} 
combating Boko Haram's recruitment. The sixth part concludes the findings, recommendations, and avenues for further research.

\section{Methodology}

As stated in the introduction, this article, adopts the qualitative research approach through the use of academic, non-academic documents, reports, and personal interviews in the form of key informant interviews, with community and religious leaders, academic and policy experts, and individuals affected by the activities of Boko Haram. These key informants represent individuals from academia, members of the security sector, civil societies, faith-based organizations, community and opinion leaders, and also some residents of the affected areas by the activities of Boko Haram (Adamawa, Borno, and Yobe states).

The selection of this group of informants was informed by their expertise and contribution to the subject. They represent targeted groups with primary or first-hand experience on the Boko Haram challenge and its implication on peace, security, stability, and development of the northeast and the Lake Chad region. In specific terms, these informants were asked questions related to the various Boko Haram recruitment strategies (BHRS), the measures taken by relevant stakeholders (national governments, sub-regional, and regional actors like the Economic Community of West African States, the Lake Chad Basin Commission, and the contribution of civil society groups and faith-based institutions) in addressing these BHRS, and the challenges confronting these actors in combating BHRS across Lake Chad. The interviews and research process were conducted from the period starting 1 June, 2018 to December, 2019. While the study respects and maintains the anonymity of these key informants (respondents), their areas of expertise, affiliations, and initials were used sparingly for better clarity.

\section{Terrorism Recruitment (TR) and Boko Haram's Recruitment Strategy: What Does the Literature Say?}

\subsection{Terrorist Recruitment: Conceptual Clarification and Theoretical Discussions}

As suggested by Forest (2006), there is no universally accepted definition for the concept of terrorism recruitment (TR). However, most studies on terrorism are of the opinion that terrorism recruitment refers to the various sociological, political, economic, ideological, religious, and psychological strategies and tactics used by terrorist organizations to enlist members (Faria and M 2005; Neumann 2012; Özeren et al. 2014; Klein 2016; Bloom 2017). These strategies could be violent or non-violent as well as the integration of the various socio-cultural, economic, ideological, psychological, and political conditions that motivate individuals into joining terror groups (Post et al. 2002; Forest 2006; Knapton 2014; Jones 2017).

Most theoretical discussions on terrorist recruitment situate their narratives on the basis of the Social Movement Approach (Gentry 2004). This is because the theory places emphasis on the narrative that most terrorist organizations started as informal and semi-structured groups focusing on certain societal issues and challenges affecting societies (Beck 2008). These challenges enabled them to create the false perception among individuals and targeted groups leading them to believe that they can provide a better alternative. These movements are predominantly anti-establishment, anti-status quo, and anti-elitist, seeing them as the reasons for creating the conditions for the social problems affecting societies (Shannon 2011; Prud'homme 2019). These movements create the opportunity and space for terrorist organizations to mobilize and recruit members given that their messages resonate some level of social consciousness that appeals to individuals and groups with grievances against the establishment (Kruglanski and Fishman 2009; Newton 2011; Ortbals and Poloni-Staudinger 2014; Özeren et al. 2014; Del Vecchio 2016; Klein 2016). Consequently, these terror groups continue to use the platform they have under the pretext of social movements as a strategy for not only recruitment; these recruits are continuously engaged by these violent extremist groups to ensure the sustainability and survival of such movements (Pieri and Zenn 2018). The emphasis on ensuring the group's survival 
is an important component through which relevant stakeholders involved in countering the threat posed by terror groups and their expansionist agenda should explore and address. This is because any process of disengagement and counter-terrorist recruitment requires a high level of effort by these actors to limit the influence of some of these negative social movements (ibid).

It is important to note that despite the advantage of social movements as instruments of social change in societies, where they serve as a vehicle for easy mobilization (Hairgrove and Mcleod 2008), they also offer some level of legitimacy for individuals and groups aggrieved by certain societal dysfunctions to express their resentments against the current social order by effecting positive change (Joosse et al. 2015). With the ability to mobilize and a wider reach to a targeted population to disseminate their messages, terrorist groups easily exploit these avenues and opportunities provided by these movements to recruit individuals and groups who share similar radical religious and ideological beliefs (Sarjoon et al. 2016; Smith et al. 2018; Madonia and Contreras 2019).

As put forward by Loimeier (2012), Adegbulu (2013), and Murtada (2013), Boko Haram emerged from the various social movements that existed in the northern part of Nigeria, including Mohammed Marwa's Maitatsine ${ }^{6}$ movement of the 1980s to the Sahaba Muslim Youth Organization, Abubakah Lawan's Ahlulsunnawal Jama'ah, and the Yobe Taliban, which existed from the 1990s to the early 2000s (Aghedo 2014; Olojo 2015; Azumah 2015; Chiluwa 2015; Gray and Adeakin 2015; Voll 2015; Iyekekpolo 2016; Pieri and Zenn 2016; Amaechi 2017; Magrin and Montclos 2018; Rasak 2018). These organizations later evolved to what is today known as Boko Haram. These movements not only have a massive following in northern Nigeria, but their extreme views against secularism, and the modern state system have endeared them to many who believe they serve as an instrument for social change in Nigeria. ${ }^{7}$

Besides the social movement theoretical stance that explains the various strategies used by terror groups and other violent extremist groups, to recruit fighters, another theory that seeks to explain the paradigm of terrorist recruitment is the anthropological emphasis on culture as an avenue these terror groups used to attract and enlist recruits into their folds (Pieri and Zenn 2018). This theory extends the narrative by studies that situate their focus and emphasis on the daily ideological and operational drivers used by these groups to recruit fighters. This approach focused on the level of social engagements, inter-group relations, solidarity, and bonds created by this jihadi culture (Pieri and Zenn 2018). To sum up, this approach explains this paradox of terrorist recruitment as a lifestyle through which people learn over time (Pieri 2019).

Relating this to the Boko Haram recruitment strategy, studies revealed that beyond the public propaganda and instrumentalization of violence by this terror group, Boko Haram has interacted and built inter-group relations, strong communal bonds, loyalty, and solidarity (MacEachern 2018; Agbiboa 2019; Pieri 2019). This form of loyalty, social cohesion, and culture enabled the group to not only attract naïve individuals into joining them (Boko Haram), but also making it possible for the group to ensure that these recruits see the "jihadist culture" as nothing but a way of life (Pieri and Zenn 2018). It reflects this pattern of lifestyle in its members engaging in the popular motor-cycle transportation business popularly called 'achaba' in communities they control (Agbiboa 2019). Members of the group are also said to regularly interface and interact with the locals in communities they control. They also engage in preaching their jihadist messages, expressing themselves in comedy, music, drama, dance, and other forms of entertainment in the Arabic, Kanuri, and Hausa ${ }^{8}$ languages (Pieri and Zenn

6 The Maitatsine ragtag Islamic group was a radical sect with over 3000 members under the tutelage of a Cameroonian Islamic Mufti Mohammad Marwa. This sect was predominantly in Kano state, in the Northern part of Nigeria and was principally aimed at bringing Islam back, which they considered then was gradually losing its meaning in the north because of the belief that liberal-oriented values were corrupting the Muslim lifestyle. Therefore, they considered themselves reformists to the tenets and teachings of Islam. Their activities frequently led to violent confrontations with government operatives. These violent confrontations resulted in crises between 1980-85, destroying many lives and properties.

7 Most studies have offered similar anecdotes on the evolvement of this terrorist organization.

8 These three languages are mostly and widely spoken by communities and locals across the northeast and Lake Chad region. 
2018). Therefore, it is said that the group adopts this tactic as a strategy to attract individuals into joining them. This is because these locals see them as ordinary people, interacting with ordinary locals regardless of the popular narrative that the group (Boko Haram) uses violence to propagate its messages to the public.

Studies by other scholars (Adegbulu 2013; Hill 2013; Zenn et al. 2013; Aghedo 2014; Olojo 2015; Chiluwa 2015; Gray and Adeakin 2015; Pham 2016; Pieri and Zenn 2016), focused on the negative misrepresentation of ideology and the weaponization of religion by terrorist organizations such as Boko Haram to recruit members. This could be seen through the negative teachings given by Mohammed Yusuf to his followers that Islam abhors 'Western civilization' and all its imprints (see Umar 2012, p. 144). Such messages increasingly created the false perception that Western civilization is anti-Islamic and most of the problems affecting the society are linked with the saturation of Western values in Nigerian society (Hansen 2017; Zenn 2018). These negative misrepresentations and the instrumentalization of religion encouraged individuals to join Boko Haram. Olojo (2017), Magrin and Montclos (2018), were of the view that despite the negative use of religion as a tool for terrorist recruitment, it also plays a vital role in deradicalization and also dissuading individuals from becoming members of terrorist organizations. According to their analysis, religious leaders and clerics have a role in changing the narrative and negative representation of religion used by terror groups to recruit members.

Further studies (Ayegba 2015; Eke 2015; Dowd and Drury 2017; Oriola 2017; Rufai 2017; Ajala 2018; Babatunde 2018; Hentz 2018) focused on the multidimensional challenges confronting Nigeria, which enabled Boko Haram to exploit and lure individuals into joining their crusade. These challenges ranged from the long history of conflict in the country, the inability of the government to address the problems of bad governance, corruption, poverty, unemployment, provision of social services to citizens, marginalization, and inequality, which paved the way for alienation and a lack of trust between citizens and their leaders. These conditions of social exclusion and disillusionment, especially in the northern part of Nigeria, created an avenue for radical groups to conscript individuals to their groups, like in the case of Boko Haram.

\subsection{Boko Haram's Recruitment Strategy}

Before delving into the various strategies used by Boko Haram to recruit members, it is important to note that as an organization with over 6000 active fighters and transnational reach, Boko Haram has recruited individuals from Cameroun, Chad, Niger, Mali, and Libya (The Guardian News 2015; Walker 2016; Sampson 2016; Adelani et al. 2017; Mentan 2017; Rufai 2017). A discussion with an informant agreed with the position put forward by (David et al. 2015), that revealed three factors which contributed to the transnational reach of the organization to recruit foreign fighters. First, the poor state of Nigeria's border enabled people to illegally migrate into the country with no form of border checks by immigration officers. Second, the abuse of the Economic Community of West African States (ECOWAS) policy on the free movement of persons across the sub-region created the avenue for criminals and mercenaries to easily move around. Third, the societal, cultural, and religious ties of Nigerians in the northeast with citizens of countries in the Lake Chad and the Sahel regions, especially Chadians, Nigeriens, and Malians, allowed people to easily integrate with little difficulty. These three factors have made Boko Haram more ambitious in increasing its membership and attracting fighters from these countries. ${ }^{9}$ Therefore, the international composition of Boko Haram has downplayed the stereotype and negative perception that members of this organization are Nigerians, illiterates, and poor. ${ }^{10}$ This is because various studies have revealed that Boko Haram attracts and recruits individuals from diverse socio-economic, educational, cultural, religious, and ideological backgrounds (Umar 2013;

9 Interview with a Senior Lecturer, Center for Peace and Security Studies, Modibbo Adamma University, Yola, Adamawa State, Nigeria, 24 June 2019

10 Interview, 24 June 2019 
Mercy Corps 2016). Because of this, it would be wrong to claim that recruitment into Boko Haram is restricted to a certain group of people in society.

Terrorist organizations rely on people and manpower to carry out their activities (Asal et al. 2012; Clauset and Gleditsch 2012). Boko Haram, like most terrorist organizations, deploys several strategies for recruiting individuals. These strategies involve techniques such as coercion, consent, hypnosis, and the promise of financial incentives (see Campbell 2013; Torbjornsson and Michael 2017).

The alleged false promise of better welfare and improved economic conditions is identified as a strategy used by Boko Haram to recruit their members. Studies have shown that most individuals cite the lack of economic opportunities, poverty, unemployment, and access to better welfare as reasons for joining Boko Haram (Onapajo and Uzodike 2012; Zenn 2013b; Umar 2013; Fessy 2016; Mercy Corps 2016). Terrorist groups like Boko Haram capitalized on the inability of the Nigerian government to provide these services and opportunities to its people by promising them these financial incentives if they are recruited (Fessy 2016). The narrative that Boko Haram pay as much as $\$ 3000$ daily to its fighters has further attracted and motivated individuals to join this organization, driven by the desire for better economic welfare (Nduka 2019).

Forceful conscription is another strategy used by Boko Haram to recruit members into the organization (Ajayi 2014; Walker 2016; Oriola 2017; Markovic 2019). Increasingly, research and reports have shown that since the activities of this terrorist group became manifest in 2009, the organization has enlisted over 8000 children who perform combat and non-combatant activities for the terrorist group (See Adnan 2019; BBC News 2019; Human Rights Watch 2019). It has kidnapped girls and women who have been forced into carrying out suicide attacks, while others serve as cooks and wives for members of the terrorist group (Brock 2013; Ameh 2014; Dixon 2014; Swails and David 2016; Nwaubani 2017, 2019). A report published by the Global Terrorism Database revealed that over 150 incidents of suicide attacks carried out by the group across Lake Chad were committed by children and women, making it the terrorist organization that recruits the highest proportion of women, as they constitute fifty percent (50\%) of their suicide bombers (START 2018). In a conversation with one of the authors, an informant from Maiduguri further revealed that "it is no longer news that Boko Haram is forcing and using their women as suicide bombers; they constantly rape, and impregnate them, which they claim to be preparing the next generation of terrorists to continue their ideology"11 This strategy of forceful conscription adopted by Boko Haram for recruitment supports the narrative that it reduces the financial burden on the organization to spend resources on paying for fighters. It further helps in projecting their publicity and propaganda, and justifies the perception that children and women can easily infiltrate their targets with little suspicion (Galehan 2019).

Using cash loans traps is another method employed for recruitment by Boko Haram (Zenn 2013a; Abrak 2016; Guilberto 2016). Boko Haram uses this as a business model to assist the youths that are not employed and traders struggling to sustain their businesses to start new ventures and also to sustain their ailing businesses (Sigelmann 2019). Those unable to pay back the loans are coerced into joining the organization or volunteer by providing sensitive information on the movements and activities of the Multinational Joint Taskforce (MNJTF), who are responsible for combating the activities of the group in Lake Chad (Abrak 2016; Gaffey 2016; Magrin and Montclos 2018). A transnational threats expert admitted when being interviewed that even though loan-traps is a strategy for recruitment by Boko Haram, the control of fishing activities in the Lake Chad area by the terrorist group allows them to recruit individuals who are unable to pay back their debts by employing them in this fish farms as a precondition for paying back their loans. ${ }^{12}$ That has not only increased the organization's capacity to raise funds, but has also enabled it to increase its membership base. ${ }^{13}$

11 Author's discussion with a resident of Maiduguri 18 March 2019.

12 Interview with a Senior Researcher, Transnational Threats, and International Programme, Institute for Security Studies, Pretoria, South Africa, 7 January 2019

13 Interview, 7 January. 
Recent studies on terrorist recruitment shows the transnational effect of advancements in information and technology, where the internet and its tools, especially social media, has become a recruitment hub for terrorist organizations to recruit fighters (Guadagno et al. 2010; Archetti 2013; Gates and Podder 2015; Weimann 2016; Ette and Joe 2018). This assertion has been supported by the statement credited to His Royal Highness Sanusi Lamido Sanusi the Emir of Kano, who said that the increasing exposure to and obsession with social media among youths and children, especially Facebook, Twitter, YouTube, and WhatsApp, has had a negative impact on entrenching ethical values (Madugba 2015). This is because through personal networks and friendships developed in this virtual space, children are sometimes exposed to this negative indoctrination and manipulation of ideas by these extremist groups (lbid). In a conversation with the author, a community leader in Angwan Rimi in Jos shared a sad experience that involved his niece who left home in November 2015 and travelled to Maiduguri (Borno State) to meet a Saurayi (Boyfriend) whom she supposedly met on Facebook. Unfortunately, this was the last time that she was seen as she disappeared and several searches produced no successful results. The last news the family received regarding her was that she had been married to a unit commander of Boko Haram. This story is one of many in which young people are deceived by strangers they meet online who have the ulterior motive of recruiting them into violent extremism. He concluded that it is the responsibility of parents to carefully monitor what children do with their phones. ${ }^{14}$ Therefore, it is important to note that terrorist groups such as Boko Haram increasingly use such platforms to share their videos, promote their ideology and propaganda, and transnationally appeal to individuals sympathetic to their cause to motivate them to join the group in their aim of eradicating the supposed moral decay in northern-Nigeria because of the influence of Western civilization (UNDP 2017; Ette and Joe 2018; Slutzker 2018).

Instrumentalizing Religion negatively is another strategy and instrument used by Boko Haram to recruit members (Onapajo and Uzodike 2012; Voll 2015). Most studies on terrorism and Boko Haram have cited radicalization, false teachings, and misrepresentation of religion by rogue clerics to hypnotize, and recruit unsuspecting individuals into joining terrorist organizations. ${ }^{15}$ Studies by Onuoha (2014a, 2014b; Olojo 2017) revealed that these radical clerics capitalized on the socio-economic and cultural challenges facing the northeast region to indoctrinate people into believing that their problems resulted from Western civilization. This negative sentiment about western civilization was re-echoed by a journalist who conducted a series of studies on the insecurity in the northeast ${ }^{16}$ and a former commander ${ }^{17}$ of the MNJTF, who maintained that since 'Boko Haram' is against 'Western education and civilization', which it perceives to be anti-Islam, it should not surprise people that the organization uses the false narrative to appeal to the hearts and minds of people. This is because Muhammed Yusuf, the founding leader of Boko Haram, attracted followers because of his anti-Western sentiments and teachings, who were largely uneducated, unschooled, impressionable, poor, and frustrated by the status quo. ${ }^{18}$ This is a strategy the organization continues to use to recruit and expand its base across the Lake Chad region (See Sigelmann 2019).

The negligence and inability of the government to address certain basic fundamental issues affecting the northeast region contribute to increasing the space for Boko Haram to thrive and expand its activities (Sigelmann 2019). The inability of the Nigerian government to address the problems of unemployment, human rights abuses, poverty, social exclusion, radicalization, illiteracy, inequality, and the provision of basic social services to its citizens created the opportunity for radical, violent extremist, and terrorist organizations such as Boko Haram to not only assume the place of the government, but also expand its membership (Campbell 2013, 2018a, 2018b; Matfess 2016, 2017; Magrin and Montclos

14 Author's Interview with a Community Leader in Jos, Plateau State, Nigeria, 21 June 2019.

15 Authors' findings from most studies on terrorism and Boko Haram.

16 Interview with an Author, Journalist, and Researcher on Violent Extremism in Northern Nigeria, 30 December 2018.

17 Phone Interview with a former Commander of the Multinational Joint Task Force against Boko Haram, 6 November 2018.

18 Phone Interview, 6 November. 
2018). The abdication of responsibility by the government in the northeast resulted in people resorting to seek help from Boko Haram to provide basic services such as water, food, and medical supplies (Sahara Reporters 2019). A former resident of Bama in Maiduguri revealed that Boko Haram not only supply food in some of these villages, but they also collect taxes and provide security for members of such communities. Through that, members of such villages not only see an alternative government in Boko Haram, but it motivates them to join the organization. ${ }^{19}$ Therefore, so long as the government continues to show this level of negligence and failure in addressing the issues and challenges affecting the people of the northeast and the Lake Chad region, Boko Haram will continue to exploit these lapses and attract more fighters into its ranks.

These tactics reflect why and how the terrorist group continues to expand and consolidate its base across the Lake Chad despite the various measures countering it.

The figure below (Figure 1) presents a pictogram map of the four countries of the Lake Chad region affected by the activities of Boko Haram.

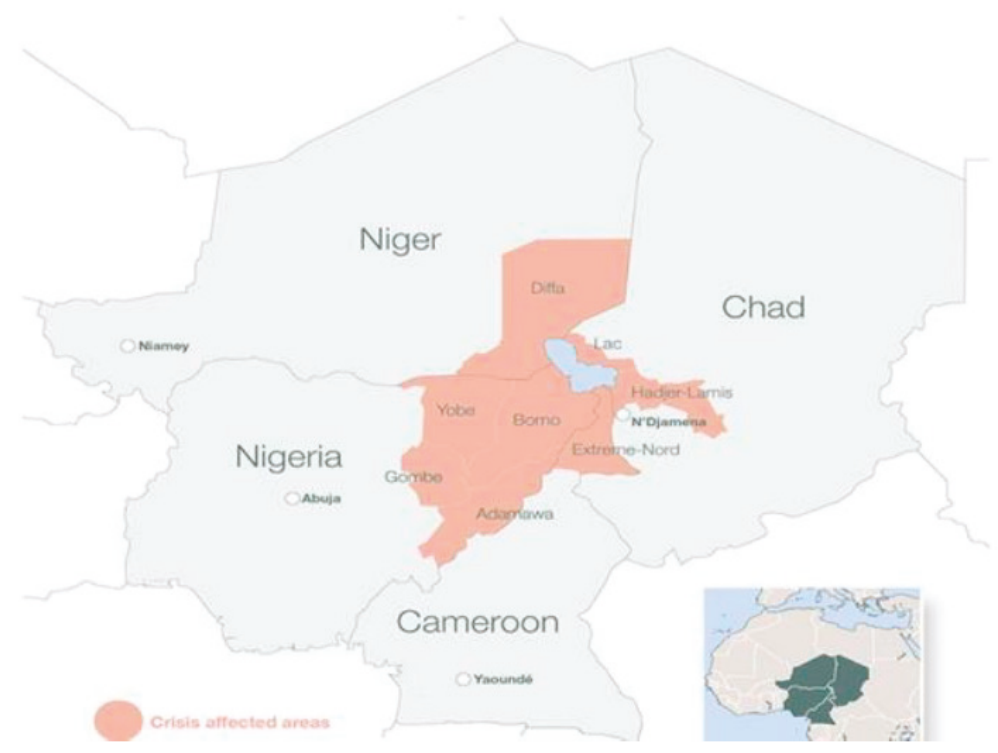

Figure 1. The affected countries of the Lake Chad region. Source: Smith 2016. "The Lake Chad crisis explained".

4. What Are the Efforts and Strategies towards Preventing Boko Haram's Recruitment: National, Civil Society Organizations (CSOs) and Faith-Based Organizations (FBOs), Sub-Regional and Regional Responses?

This part of the article is categorized into three sub-sections. The first section examines the response at the national level, where the emphasis was on the administrative and legislative roles initiated by the Nigerian government to counter Boko Haram's recruitment. Also, the analysis goes further to examine the roles played by religious groups (faith-based organizations) and civil society organizations in stemming the recruitment strategy deployed by Boko Haram. The third sub-section examines the role of sub-regional and regional actors such as the Lake Chad Basin Commission (LCBC),

19 Interview with a former resident of Bama Local Government in Maiduguri, 19 June 2019. 
the Economic Community of West African States (ECOWAS), and the African Union (AU) in countering the recruitment ability of Boko Haram operating in the Lake Chad area.

\subsection{National Response}

The statement made by President Muhammadu Buhari of Nigeria at the $73^{\text {rd }}$ session of the United Nations General Assembly that "the terrorist insurgencies we face, particularly in the Sahel and Lake Chad Basin, are partly fueled by local factors and dynamics, but now increasingly by the international jihadi movement, runaway fighters from Iraq and Syria and arms from the disintegration of Libya," and called for global action to counter the threats of terrorism (United Nations News 2018). This statement not only further explains the changing tides of insecurity in Lake Chad, but also the capacity of terrorist organizations such as Boko Haram and its splinter group, the Islamic State West Africa Province (ISWAP), to recruit, expand, and continue to carry out several attacks across the northeast and Lake Chad region (Salkida 2019).

Various studies (Agbiboa 2015; Oyewole 2015; Assanvo et al. 2016; Bappah 2016) have reflected on several efforts by states and non-state actors at the national, sub-regional, and regional levels to counter the operational capacity of Boko Haram to recruit and carry out attacks. At the national level, the Nigerian government has engaged in a series of administrative, legislative, and inter-agency collaboration efforts between local institutions and international agencies to counter the activities of Boko Haram.

Some of the administrative measures adopted by the Nigerian government included: the multi-track approach, which involved persuasion, dialogue, and consultation with political, religious, and community leaders in the states and communities affected by activities of the terrorist group to counter the narratives of radicalization and other negative doctrinal elements (Olojo 2017, 2019); the declaration of a state of emergency in Adamawa, Borno, and Yobe states accompanied by the five-year trade embargo placed along 'Dikwa-Maiduguri-Gamboru-Ngala routes' to interdict the transnational crime activities by Boko Haram (Sahara Reporters 2013; Samuel 2019); and the launch of the National Action Plan for Preventing and Countering Extremism in 2017 to strengthen the capacity of agencies to tackle violent extremism, enforce the rule of the law and human rights, enhance effective community engagement, capacity building and resilience to counter violent extremism, resilience, and strategic communication by various stakeholders and actors in the society (Ogunmade and Olugbode 2017).

Furthermore, other initiatives were launched such as the 'Buhari Plan of 2016' for effective and transformative engagement between the government, religious organizations, and communities affected by the activities of Boko Haram in the northeast (see African Union 2018, p. 17). The newly established 'Presidential Committee on the North-East Initiative' was saddled with the responsibility of developing a comprehensive strategy towards rehabilitating, reintegrating communities, rebuilding and reconstructing the northeast (Punch News 2016). The launching of the 'Operation Safe Corridor' was aimed at addressing challenges associated with terrorist recruitment, violent extremism, deradicalization, rehabilitating and reintegrating repentant Boko Haram terrorists back to society after undergoing various stages of thorough psycho-spiritual therapy and evaluations by religious clerics and psychology experts (DW News 2019).

Due to the fact that terrorist recruitment is connected to the capacity of terror groups to fund their operations (Clarke 2015), the Nigerian government is a member of the Inter-Governmental Action Group against Money Laundering in West Africa in line with the mandate of the Financial Action Taskforce on Counter-Terrorism Financing (See GIABA 2015; Financial Action Task Force 2016). At the legislative level, the National Assembly comprising the Senate and the House of Representatives amended the 2011 Terrorism (Prevention) Act. The amended law was expected to support inter-agency counterterrorism collaboration between various actors to combat terrorism. It strengthened the capacity of law enforcement officers to detain and prosecute individuals suspected to be sponsors and members of terrorist organizations (see Federal Government Nigeria 2011). It also boosted the capacity of institutions to deal with the sponsors of terror-related activities. The amendment 
further allowed for the death penalty to be given as punishment for individuals and groups found guilty of committing and facilitating acts of terror in the country (See Federal Government Nigeria 2011, 2013). This legislation further strengthened the Money Laundering Prohibition Act of 2011 and also led to the establishment of the National Financial Intelligence Unit (NFIU) by financial institutions to prevent terrorist organizations such as Boko Haram from not only funding their operations, but also expanding their activities by recruiting fighters (see Nigerian Financial Intelligence Unit 2018).

\subsection{Response from Faith-Based Organizations and Civil Society Organizations}

Studies have shown that the Muslim and Christian communities and places of worship constitute the sectors that are mostly affected by the attacks carried out by Boko Haram across Lake Chad with over 2134 fatalities recorded across both communities in 2018 (see Nigeria Watch 2019). These attacks further affected the already deplorable and tense Christian-Muslim relations that have characterized most of the conflicts and tensions between these two religions in recent years (Michael Kpughe 2017; Faseke 2019; Nche et al. 2019).

Despite the attacks on religious institutions by Boko Haram, under the broader Coalition of Civil Societies with over 5000 registered agencies, the two dominant religions have engaged in various 'non-violent' engagements to fight against the forces of violent extremisms, radicalization, and terrorist recruitment across the Lake Chad region (See Mahmood and Ani). Religious leaders also use their understanding of the true doctrinal principles to discourage the narrative and ideological propaganda employed by Boko Haram to recruit fighters (Olojo 2017, 2019). An example can be seen in Sokoto State where the Muslim Umma (Muslim Community) stopped and chased Kabiru Sokoto ${ }^{20}$ out of the state in order to prevent the indoctrination of people through his radical ideology (Adamu 2012).

Furthermore, through effective collaboration between these religious bodies and civil society organizations, several initiatives, peace concerts, and peacebuilding outreaches were implemented in various areas affected by the threat of Boko Haram. ${ }^{21}$ As informed by one interviewee, one of such initiative was the Hadin Kan Mu Karfin Mu (Our Unity, Our Strength) and the Ido da Ido (Face to Face) project organized by International Alert Nigeria (IAN) ${ }^{22}$ in July 2019, with the support of religious groups and the communities of Adamawa, Borno, and Yobe state ${ }^{23}$ considered to be the three states most affected by the activities of the insurgents (See Zirima 2018). This initiative was aimed at "Reinforcing the Resilience and Re-integration of Women and Children, Promoting Peacebuilding in Communities affected by Boko Haram and strengthening effective engagement between community vigilantes and security officers across affected areas." ${ }^{24}$ It was expected that this project would help targeted groups address the problems of radicalization, lack of diversity management, mutual coexistence, and intolerance, and help strengthen mutual trust amongst communities irrespective of their religious beliefs for sustainable peace. ${ }^{25}$ Also, a decision was made by the Borno State government and the Borno State Islamic Association to establish peace clubs, as well as to design the curriculum used by educators for the teaching of peace studies for children attending the Western schools at both the primary and secondary level, and also those children attending religious schools or Madrasas (See TRT World News 2018). The adoption and establishment of peace studies and peace clubs will help inculcate sound doctrinal teachings in line with the dictates of the holy books (Bible and Quran) and also counter the negative narratives and ideologies used by extremist groups to recruit children. ${ }^{26}$

20 A Boko Haram fighter suspected to be the brain behind the December 2012 Christmas Day bombing at the Catholic Church located at Madallah, Niger State in Northcentral Nigeria.

21 Interview with the Director of Protocol Church of Christ in Nations, 30 April 2019

22 It is an international Non-governmental Organization with the mission of breaking the cycles of violence and building sustainable peace through constructive engagement with communities and groups directly affected by violent conflict.

23 Interview with a Senior Program Officer at International Alert, North-East Nigeria, 22 September 2019.

24 Interview, 22 September 2019.

25 Ibid.

26 Phone Interview with Mallam B.M., A Peace Club Teacher in Maiduguri, Borno State, 2 August 2019. 
These initiatives contributed to raising awareness on the dangers of extremism, promoted social cohesion and mutual trust amongst various communities and groups affected by the activities of the terrorists. ${ }^{27}$ This sentiment was also shared by Nigeria's Chief of Army Staff Major General Tukur Buratai in a seminar organized by the Nigerian Army Directorate of Chaplain Services, and Directorate of Islamic Affairs with the theme "Countering Insurgency and Violent Extremism in Nigeria through Spiritual Warfare", where he called on religious groups and leaders to support the state in eradicating the negative use of religion and ideology to fuel insurgency in the country (Nigerian Tribune 2019). He argued that "defeating the ideologies of Boko Haram and ISWAP requires actors to first realize that it was this negative use of ideologies that enhanced the resource base and ability of these terror groups to recruit fighters to join their crusade" (Premium Times 2019). Therefore, terrorism will wither if these negative forces of radicalization are eradicated. This can only be achieved through concerted efforts and the continuous interface between religious leaders, groups, communities, and the military in countering these radical ideologies and protecting vulnerable groups from falling victim to extremists' beliefs and doctrines (Premium Times 2019).

Therefore, it is important to note that continuous emphasis on inter-faith dialogue and cross-cultural engagements between locals, religious and civil societies on peaceful coexistence, tolerance, and deconstructing the narrative that no religion supports violence can contribute to curbing the threat of terrorism, including its efforts to recruit and expand (Michael Kpughe 2017; Olojo 2017; Salifu and Ewi 2017; Brechenmacher 2019).

\subsection{Sub-Regional and Regional Response}

As a member of the Trans-Sahara Counterterrorism Partnership (TSCTP)' and the Islamic Military Alliance (IMA)', Nigeria continue to engage with states and non-state actors at the international level to counter extremist messaging, narratives, and ideologies used by Boko Haram and other terrorist organizations to recruit members (Agence France Presse 2016; Martin 2018; United Nations 2018). The Regional Strategy for the Stabilization, Recovery, and Resilience (RSSRR) was launched in the areas affected by the activities of the Boko Haram terrorists by the Lake Chad Basin Commission, with support from the African Union, United Nations, and other non-state actors. The RSSRR strategy offers a multidimensional approach that allows governments, civil societies, religious organizations, and communities to strengthen the institutional capacity to combat terrorism and all its imprints in the region (see African Union 2018). These engagements, partnerships, and initiatives established by states and non-state actors in stemming the recruitment capacity of Boko Haram in the Lake Chad region were expected to not only identify the key drivers of public support for terrorist organizations, but also counter the negative ideologies and the various methods used by terrorist groups to consolidate and expand their operations through recruitment. ${ }^{28}$

The joint military coalition between member states of the Lake Chad Basin Commission under the Multinational Joint Taskforce (MNJTF) achieved some success by limiting the territorial expansion of the terrorist organization to other parts of the continent and degrading its capacity to carry out coordinated attacks (Iwuoha 2019). The recapturing of Baga and other communities previously controlled by the terrorists affected their ability to recruit and fund their operations. ${ }^{29}$

To conclude this section, it has been argued that the measures and initiatives taken by stakeholders at the national, sub-regional, and regional levels achieved some success in preventing the recruitment ability and territorial expansion of Boko Haram from spreading to other parts of the continent by limiting their presence to the Lake Chad region (see News Express 2015; Lake Chad Basin Commission News 2019). The trade blockade along Dikwa-Maiduguri-Gamboru-Ngala trading routes impacted

27 Phone Interview, 2 August 2019.

28 Discussions with A Conflict Resolution and Security Expert with Advocates Coalition for Development and Environment (ACODE), Kampala, Uganda, 3 January 2019.

29 Interview with an Executive Assistant Commissioner Finance, ECOWAS Commission, Abuja-Nigeria, 22 October 2018 
the illicit funding of activities by this group, thus hindering its capacity to attract further fighters (Omenma 2019; Samuel 2019). The continuous engagement and the role played by faith-based organizations and clerics across the northeast and Lake Chad in deconstructing the negative narratives and propaganda used by Boko Haram to project their religious and ideological sentiments affected their expansion and recruitment capacity (Olojo 2017; Michael Kpughe 2017; ACN News 2018).

\section{What Are the Challenges Facing Stakeholders in Combating Boko Haram's Recruitment?}

The various initiatives designed to counter the operational capacity of Boko Haram to recruit and expand its activities face a series of challenges. This is because, despite these measures, the group continues to thrive by attracting fighters across Lake Chad (Punch News 2017; Sigelmann 2019). During one interview, one informant expressed the opinion that one challenge confronting actors in countering the recruitment of individuals into extremist and terrorist organizations such as Boko Haram, is "the ignorance and belief by actors that there is a universal solution to counterterrorism without clearly understanding the context, local dynamics, and situations that allows terrorism to thrive. This is because, individuals are motivated and driven by several reasons to join terrorist groups". ${ }^{30}$ Therefore, the inability of actors to understand and identify reasons individuals join terrorist organizations impedes any counterterrorism strategy designed to combat terrorist recruitment by actors. ${ }^{31}$ This narrative is supported in several studies, which suggest that the complexity of the conflict in the Lake Chad where multiple terror groups like Boko Haram and its factional group Islamic State West African Province (ISWAP) are involved in the conflict, with each group having its separate rules of engagement and modus operandi (Bappah 2016; Anyadike 2018). This makes it difficult for actors to defeat them using the current state-centric or military strategy (Munshi 2018; Mentone 2018; Salkida 2019). This is because the current approach is not only reductive, but also fails to involve all relevant stakeholders in countering terrorist threats (see International Crisis Group 2016; Salkida 2019). It also does not identify the drivers of the conflict, guarantee stability of the region, enhance social cohesion, and seek sustainable solutions that will stem violent extremism, terrorist recruitment, and terrorism across the Lake Chad region (Sigelmann 2019; Zenn 2019). That explains the recent calls by actors and stakeholders to change the strategy by incorporating a multidimensional approach that will incorporate all relevant actors when tackling terrorism in the Lake Chad region to reflect the current realities and dynamics of the conflict (Olojo 2019).

Another challenge confronting actors is the technological deficit and lack of trust among actors involved in managing the conflict and communities affected by Boko Haram to identify threat forces affecting the fight against terrorism recruitment. ${ }^{32}$ The accusation and perception that members of the MNJTF and individuals in the host communities act as double agents and informants for the terrorists affects any approach to counter and limit the activities of Boko Haram across the northeast and Lake Chad region (Agbiboa 2018). This is because increasingly, soldiers and officers of the MNJTF are accused of divulging sensitive operational and tactical information to the insurgents, supplying them with weapons and aiding their illicit trafficking of stolen goods and other contraband products across Lake Chad (Dietrich 2015; Solomon 2017; Premium Times 2018). That has impacted negatively on the image of members of the security sector, where several reports and commissions of inquiries have accused the military of committing a series of human rights violations such as rape, extortion, extra-judicial killings, looting of properties, arresting innocent locals, and branding other communities as suspect areas (See Galtimari 2011; Abbah 2012; Amnesty International 2018). This has negatively impacted the civil-military relations amongst communities and soldiers across Lake Chad, as locals often clash with soldiers accusing them of collaborating with Boko Haram for financial settlements (Agbiboa 2018).

30 Interview with a Journalist/Reporter with Premium Times News Paper, covering the situation in the northeast and Lake Chad, 18 May 2019.

31 Interview, 18 May 2019.

32 Phone Interview with a member of the Presidential Committee on Small Arms and Light Weapons-PRESCOM, 12 March 2019. 
This negative perception complicates any avenue for effective civil-military engagement, support, and trust between the military institutions and communities affected by the terror acts committed by Boko Haram. This high level of mistrust affects any response towards preventing Boko Haram's recruitment capacity as well as stopping them from carrying out various acts of barbarity. ${ }^{33}$

The lack of trust in the management and utilization of intelligence amongst actors has been revealed by various studies, which highlighted the importance of having an effective surveillance and intelligence system to assess, monitor and report threats of terror-related activities (Donovan et al. 2016; Göpfert 2016; Agbiboa 2014, 2018). This level of mistrust affects any effort by relevant actors to combat the activities of terrorist organizations such as Boko Haram to recruit and carry out attacks across the northeast (Brechenmacher 2019). This position also reflects the eyes on the street analogy put forward by Agbiboa ${ }^{34}$, which points out the failure of relevant actors to combat Boko Haram's recruitment strategy and terrorism in the northeast. Despite its effectiveness in managing threats and threats perceptions, this approach could not yield the desired result due to levels of mutual suspicion between security forces and members of community continuing to grow, the non-involvement of locals in counterterrorism efforts, and the fear of being branded as an informant for or against Boko Haram (Reuters 2011; Nnodim and Olaleye 2017; Brown 2018). Consequently, individuals are reluctant to report on the workings of the terrorist group and persons suspected to be affiliated to Boko Haram due to fear of reprisals. Additionally, the fact that Boko Haram predominantly uses non-formal financial institutions to control its finances also makes it difficult for banks and other financial regulators to report any suspicious activities that facilitate acts of terror (see Financial Action Task Force 2016). This is because Boko Haram relies on non-formal channels to fund its activities, such as the collection of tax from locals, robberies, proceeds from kidnapping, and other transnational criminal activities, which makes it difficult for banks to track and report funds suspected to be for terror-related activities. ${ }^{35}$ Therefore, the inability of the relevant actors to stem the flow of cash by Boko Haram to stop their ability to recruit also presents certain challenges. ${ }^{36}$

Combating terrorist recruitment and elements of terrorism in society require the state and its various agencies to show the capacity to coerce and convince citizens it has the ability to end it. ${ }^{37}$ As the state has not been able to demonstrate that commitment, questions regarding its commitment and legitimacy have arisen..$^{38}$ Contextualizing this narrative in combating Boko Haram recruitment strategy as well as the conflict, the Nigerian government and other multilateral agencies have not demonstrated that they have the ability to confront this challenge.

Several factors contribute to the inability of the state and its agencies to coerce and convince citizens that it has the ability to prevent the recruitment and expansion of Boko Haram across the Lake Chad region. In the aspect of policy operationalization, examples of initiatives such as the National Counter Terrorism Strategy (NACTEST); the National Action Plan for Preventing and Countering Violent Extremism (PCVE); the Regional Strategy for the Stabilization, Recovery, and Resilience; National Counter-Terrorism Strategy (NCTS); amongst other laudable strategies designed by the government and other multilateral institutions in the region to tackle radicalization and other conditions leading to violent extremism are yet to make any significant impact in addressing the security challenges in the Lake Chad region ${ }^{39}$ (See also European Commission 2017; African Union 2018; Mentone 2018;

33 Interview with the Program Officer at Center for Children and Crisis, A Civil Society Organization in northern Nigeria involved in providing humanitarian help to victims of Conflicts and Violence, 23 August 2019.

34 This approach centred on the use of native-traditional intelligence, and peer-to-peer collaboration between security actors and members of communities to report any suspicious activity that facilitates terror acts.

35 Discussions with Professor Warrissu Alli, Former Director of Research, Nigerian Institute for International Affairs, Lagos, Nigeria, 14 November 2018.

36 Ibid.

37 Interview with A Researcher a Conflict Resolution Researcher at the Kofi Annan International Peacekeeping Training Center, Accra Ghana, 12 March 2019.

38 Interview, 12 March 2019.

39 Interview with a Transnational Threat Expert at Institute of Security Studies, South Africa, 9 February 2019. 
Innocent 2018). The influx of foreign terrorist fighters accompanied by the illicit trafficking of arms, drugs, and other transnational criminal activities across the Lake Chad region also highlight the failure of the governments across the region to control and secure their borders against external threats (Oyewole 2015; Obamamoye 2019). The poor attitude of the leaders of member countries of the Lake Chad Basin Commission towards the deteriorating effect of climate change is a factor in creating the preconditions for Boko Haram to recruit, thrive, and expand its activities across Lake Chad (Gulland 2019). The effect of this further led to the displacement, instability, and inter-group relations of communities inhabiting the Lake Chad region (Doherty 2017; See Vivekananda et al. 2019). The negligence by the political actors allowed Boko Haram to have control of resources across Lake Chad (United Nations 2018). This has not only enabled them to recruit fighters, but also to gain ammunition for its operations (Gerretsen 2019). There has been a lack of unison in inter-agency collaboration in combating the threat of this terrorist group (United Nations 2018). The endemic corruption and lack of accountability by actors involved in combating the threat by Boko Haram has contributed to fueling the conflict (Hashimu and James 2017; Searcey and Emmanuel 2019). This is because stakeholders involved in stemming the activities of Boko Haram converted the conflict into an avenue for 'rent-seeking' and a 'cash-cow' business (BBC News 2016). This explains why despite the huge budgetary allocations, the architects of the security sector cannot address the insecurity in Lake Chad. ${ }^{40}$ Many were of the view that the fact that a 'ragtag army' such as Boko Haram could overcome a trained army demonstrates the high level and depth of corruption in the counterterrorism efforts in the northeast and Lake Chad region. ${ }^{41}$ These factors show the failure and inability of the state and its agencies to show its capacity to coerce and convince citizens that it has the ability to tackle the challenges of terrorism and insecurity across the Lake Chad region.

\section{Conclusions}

This article aimed to examine the challenges confronting stakeholders in addressing the various strategies and methods of recruitment used by the Boko Haram terrorist group across the Lake Chad region. To do that, the article focused on understanding the recruitment strategies of terrorist organizations within the context of Boko Haram, assessed the various countermeasures by relevant stakeholders at the national, sub-regional, and regional levels and the challenges confronting them in curbing the threat of terrorist recruitment across the Lake Chad region.

The findings of the article suggest that Boko Haram, like most terrorist organizations, sustains itself by recruiting individuals and groups to carry out its attacks. It achieves that by applying various methods and tactics such as the false of promise of better welfare and economic condition in a society characterized by unemployment, poverty, and the absence of basic services for the people. Through abductions, kidnappings, and threats, individuals and groups are forcefully conscripted into joining Boko Haram. Using cash loans as a means to trap unsuspecting struggling traders by being willing to support their businesses is another strategy used by the terrorist group to recruit people. Finally, the instrumentalization of religion and advancement in information technology, particularly the internet and its social media tools, by the terrorists as a vehicle and a tool to radicalize individuals constitutes another strategy used by Boko Haram for recruitment. They brainwash unsuspecting individuals into believing that Western civilization is not only haram (forbidden), but underscores the essence of traditional family, religious, and societal values exhorted by Islam. Rogue clerics use this negative narrative to attract individuals into joining the movement into believing they are contributing to effecting meaningful social change in society.

The response by stakeholders to counter these strategies included various initiatives, policies, and legislation such as the National Action Plan for Countering Violent Extremism, the Regional Strategy

40 Interview with a Senior Lecturer and Cross-Cultural Negotiator with the Department of History and International Studies, University of Jos, Nigeria, 8 September 2019.

41 Interview, 8 September 2019. 
for the Stabilization, Recovery, and Resilience among other multilateral engagements, which yielded minimal results. This is because stakeholders involved in combating the threat of Boko Haram are grappling with challenges relating to the inability to contextually identify the best strategy or approach to confront terrorism recruitment and terrorism in the region. As most terrorist organizations use violence to achieve their aims, countering their threat requires actors to understand the context and local dynamics that drive each terrorist group to determine the right strategy to prevent such groups. Another challenge identified in countering Boko Haram's recruitment strategy is centered on the gap or deficit in technology and the lack of trust among actors to identify, share, and report threat forces. For example, the lack of trust between officers of the MNJTF and members of affected communities has led to them accusing each other as acting as informants for the terrorists. This affects the efforts to counter the activities of Boko Haram across Lake Chad. The third challenge is related to the inability of the state and its various agencies to show the capacity to coerce and convince citizens that it has the ability to address the threat of insecurity across the Lake Chad region. This is due to different factors such as the failure of the state to implement various counterterrorism policies and initiatives, and the failure to secure and protect national and regional borders, thus creating an avenue for terrorist organizations to recruit and carry out various crimes. There is a lack of inter-agency collaboration to limit the activities of Boko Haram across Lake Chad, thus leading to a failure to address the endemic corruption of stakeholders involved in containing Boko Haram's presence in the northeast and Lake Chad.

Therefore, the article offers its recommendations and also suggests avenues for further studies as it relates to the measures to be taken by these actors in countering the challenges associated with counter-terrorist recruitment across the Lake Chad region:

a. A new counterterrorism strategy should be adopted that is comprehensive, multidimensional, and involves both state and non-state actors (religious institutions, civil societies, non-governmental organizations) to reflect the current realities and challenges of the 21st century.

b. Relevant stakeholders should facilitate the implementation of various initiatives such as the National Action Plan for the Prevention of Violent Extremism and other measures designed to curb the activities of terrorist organizations at the local, national, sub-regional, regional, and global levels.

c. The sociological, economic, ideological, and religious forces and drivers promoting radicalization and violent extremism across the region should be addressed.

d. Religious leaders (clerics) and faith-based organizations across the two dominant religious divides have a role to play in countering the negative ideological and doctrinal teachings used in promoting hate, violent extremism, and tensions in their localities. This can be achieved through emphasis on inter-group relations, cross-cultural engagements, and inter-faith dialogue to foster trust, mutual coexistence, tolerance, and confidence building.

e. Actors should engage in capacity-building initiatives that promote technical and vocational training for young people as a source of employment, and a process to grow resilience and prevent them from being easy targets for terrorist recruiters.

f. Policies and programs that offer rehabilitation, reintegration, and guarantee the sustainable development of individuals affected by terrorism in the region will be implemented.

g. The state and its agencies should convince citizens it has the capacity to address the threat of terrorism by providing effective services and welfare to citizens, and addressing challenges associated with poverty, unemployment, inequality, bad governance, corruption, border porosity, poor education, lack of tolerance, management of diversities, mutual coexistence, bad governance, and corruption amongst others.

h. The government and other relevant stakeholders should ensure strict compliance and regulations regarding the activities of Madrasas (religious schools) by ensuring these religious schools are fully licensed, registered, and their teachings are strictly in line with true doctrinal principles and ideals to prevent the exposure of children to negative and extremist religious doctrines. 
i. Within the context of Boko Haram and the insecurity in Lake Chad, relevant stakeholders should ensure that the channels used by this terrorist group to fund its activities are blocked. First, this involves the use of formal and informal institutions (banks, the Economic and Financial Crimes Commission) to effectively monitor and track their source of funding. Secondly, stakeholders should reclaim the control of resources (fishing and agricultural products) taking place in the Lake Chad region from the hands of Boko Haram. Finally, stakeholders should stem the illicit movements of contraband products across Lake Chad by the insurgents. These measures will prevent them from recruiting fighters if their sources of funding are stopped.

j. The criminal justice system should be strengthened to investigate cases and incidences of human rights violations by actors involved in the counterterrorism effort against Boko Haram, and persons and groups associated with facilitating and supporting the activities of terrorism should be prosecuted.

k. Parents have a role to play in ensuring that the negative forces of change and modernization do not in any way affect their children by instilling strict ethical virtues and discipline. Children should be encouraged to understand the value of hard work, honesty, and integrity.

1. A community policing model similar to the Nyumba Kumi (Ten Household and Know your Neighbor ${ }^{42}$ security initiative should be adopted. This model of community policing has been successful in Kenya, Tanzania, and Uganda in identifying threat forces and also complements the state security agencies in combating crime and mitigates the strategies used by terrorist groups to recruit and expand their activities (Ndono et al. 2019). This security initiative has been effective in strengthening the relationship and trust between locals and law enforcement officers in addressing the challenges of insecurity in East Africa (Ibid). It also contributes to promoting social cohesion, accountability, inter-religious and communal trust among groups in the society as witnessed in Nakuru County in Kenya (Andhoga and Mavole 2017). In a phone interview, an informant revealed that this initiative is an important tool in combating crime, insecurity, and terrorism in the Horn of Africa. ${ }^{43}$ This is because most societies in East Africa have a 1 to 1000 ratio of security officers to civilians; therefore, the adoption of the Nyumba Kumi can help to bridge the gap between locals and the police by acting as their 'ears to the ground and eyes on the street' on threat assessment and intelligence ${ }^{44}$. This makes it difficult for criminals and terrorist organizations to exploit any avenue to radicalize, recruit, plan, and organize attacks (Ibid). This security initiative has been successful, as witnessed in Tanzania (Sambaiga 2018). The initiative was said to have achieved some level of success in the Kayole and Eastleigh communities in Nairobi, Isiolo County, the coast of Mombasa in Kenya, and some parts of Adjumani District in Uganda by neutralizing the activities of bandits and persons suspected to be associated with Al-Shabaab and the Allied Democratic Forces terrorist groups (Kenya News Agency 2019; IOM UN Migration News 2019). With the successes recorded by this security initiative, the application of a similar model in the Lake Chad region by relevant stakeholders will help to address the challenges of insecurity as well as prevent terrorist groups such as Boko Haram from expanding their activities in the region.

m. Although this study focused on Boko Haram's recruitment across the Lake Chad region, we believe there is connection between the recruitment strategies of Boko Haram and other radical extremist groups such as Al-Qaeda in the Maghreb (AQIM), the Movement for the Unity and Jihad in West Africa (MUJAO) operating across the Lake Chad and Sahel region in West Africa, which other studies can explore.

42 Refers to a traditional community policing strategy where communities set up cells or clusters and meet regularly by sharing their security concerns and report suspected activities in their locality.

43 Phone Interview with a Senior Research Fellow at the Fort Hall School of Government in Nairobi, Kenya, 9 September 2019.

44 Phone Interview, 9 September 2019. 
n. A comparative approach to available data is also recommended, as it is likely to present the various operational levels of the terrorist groups across the Lake Chad region in order to fully understand their strategies for recruitment as well as the push and pull factors motivating individuals to joint these terrorist groups.

o. In addition to areas for further research, future researchers should try to explore issues related to the current figure of Boko Haram recruits, whether they are rising or falling across Lake Chad, what happens to the repentant and rehabilitated Boko Haram fighters, and how they are integrated back to society.

Author Contributions: Conceptualization, K.D.M. and U.K.; methodology, K.D.M., U.K. and S.A.; formal analysis, K.D.M., U.K. and S.A.; writing-original draft preparation, K.D.M.; writing-review and editing, K.D.M., U.K. and S.A.; supervision, U.K. and S.A. All authors have read and agreed to the published version of the manuscript.

Funding: This research received no external funding.

Conflicts of Interest: The authors declare no conflicts of interest.

\section{References}

Abbah, Theophilus. 2012. White Paper on Insecurity: Report Links Boko Haram with London Scholar. Daily Trust, June 3.

Abrak, Isaac. 2016. Boko Haram Using Loans to Recruit Members in Face of Crackdown. The Guardian, May 9.

ACN News. 2018. Nigeria: In the face of ongoing Islamist attacks, the faith is growing. ACN News. February 12. Available online: https://www.churchinneed.org/nigeria-face-ongoing-islamist-attacks-faith-growing/ (accessed on 13 September 2019).

Adamu, Lawan Danjuma. 2012. Nigeria: The Untold Story of Kabiru Sokoto. Daily Trust. February 12. Available online: https://allafrica.com/stories/201202130754.html (accessed on 19 August 2019).

Adegbulu, Femi. 2013. Boko Haram: The emergence of a terrorist sect in Nigeria 2009-13. African Identities 11: 2602-73. [CrossRef]

Adelani, Adepegba, Gbenro Adeoye, Jesusegun Alagbe, and Tunde Ajaja. 2017. 6000 ISIS fighters may join forces with Boko Haram-Experts. Punch News. December 16. Available online: https://punchng.com/6000-isisfighters-may-join-forces-with-bharam-experts/ (accessed on 5 July 2019).

Adnan, Abu. 2019. 8000 children recruited by Boko Haram: UN. Anadolu Agency, July 8.

African Union. 2018. Regional Strategy: For the Stabilization, Recovery \& Resilience of the Boko Haram affected Areas of the Lake Chad Basin Region. Available online: http://www.peaceau.org/uploads/rss-ab-vers-en..pdf (accessed on 19 August 2019).

Agbiboa, Daniel E. 2014. Peace at Daggers Drawn? Boko Haram and the state of emergency in Nigeria. Studies in Conflict \& Terrorism 37: 41-67.

Agbiboa, Daniel E. 2015. Resistance to Boko Haram: Civilian Joint Task Forces in North-Eastern Nigeria. Conflict Studies Quarterly. Special Issue 1-20. Available online: http://www.csq.ro/wp-content/uploads/1Daniel-AGBIBOA.pdf (accessed on 13 April 2019).

Agbiboa, Daniel E. 2018. Eyes on the street: Civilian Joint Task Force and the surveillance of Boko Haram in northeastern Nigeria. Intelligence and National Security 33: 1022-39. [CrossRef]

Agbiboa, Daniel E. 2019. Ten years of Boko Haram: How transporation drives Africa's deadliest insurgency. Cultural Studies, 1-29. [CrossRef]

Agence France Presse. 2016. Army chiefs of 'anti-terror' coalition meet in Saudi. Agence France Presse. March 27. Available online: https://www.yahoo.com/news/army-chiefs-anti-terror-coalition-meet-saudi-173438249. html (accessed on 7 July 2019).

Aghedo, Iro. 2014. Old wine in a new bottle: ideological and operational linkages between Maitatsine and Boko Haram revolts in Nigeria. African Security 7: 229-50. [CrossRef]

Ajala, Olayinka. 2018. Formation of Insurgent Groups: MEND and Boko Haram in Nigeria. Small Wars $\mathcal{E}$ Insurgencies 29: 112-30.

Ajayi, Omeiza. 2014. Boko Haram Begins Forced Recruitment. National Mirror, July 22. 
Amaechi, Kingsley Ekene. 2017. From non-violent protests to suicide bombing: social movement theory reflections on the use of suicide violence in the Nigerian Boko Haram. Journal for the Study of Religion 30: 52-77. [CrossRef]

Ameh, Comrade Godwin. 2014. Some Chibok Girls are Pregnant, Others May Never Return-Obasanjo. Daily Post, June 13.

Amnesty International. 2018. 'They Betrayed Us': Women Who Survived Boko Haram Raped, Starved and Detained in Nigeria. Amnesty International Report. Available online: https:/www.amnesty.org/download/ Documents/AFR4484152018ENGLISH.PDF (accessed on 30 April 2019).

Andhoga, Walter Otieno, and Johnson Mavole. 2017. Influence of Nyumba Kumi Community Policing Initiative on Social Cohesion among Cosmopolitan Sub Locations in Nakuru County. International Journal of Social and Development Concerns 1: 65-76.

Anyadike, Obi. 2018. Year of Debacle: How Nigeria lost its way in the War against Boko Haram. World Politics Review, October 30.

Archetti, Cristina. 2013. Terrorism, Communication, and the Media. In Understanding Terrorism in the Age of Global Media: A Communication Approach. London: Palgrave Macmillan, pp. 32-59.

Asal, Victor, Luis De la Calle, Michael Findley, and Joseph Young. 2012. Killing civilians or holding territory? How to think about terrorism. International Studies Review 14: 475-97. [CrossRef]

Assanvo, William, Jeannine Abatan, and Wendyam Aristide Sawadogo. 2016. West Africa Report: Assessing the Multinational Joint Task Force against Boko Haram. Institute for Security Studies. West Africa Report. Available online: https://issafrica.s3.amazonaws.com/site/uploads/war19.pdf (accessed on 12 August 2018).

Ayegba, Usman Solomon. 2015. Unemployment and Poverty as Sources and Consequence of Insecurity in Nigeria: The Boko Haram insurgency revisited. African Journal of Political Science and International Relations 9: 90-99.

Azumah, John. 2015. Boko Haram in Retrospect. Islam and Christian-Muslim Relations 26: 33-52. [CrossRef]

Babatunde, Olalekan A. 2018. The Recruitment Mode of the Boko Haram Terrorist Group in Nigeria. Peace Review 30: 382-89. [CrossRef]

Bappah, Habibu Yaya. 2016. Nigeria's military failure against the Boko Haram insurgency. African Security Review 25: 146-58. [CrossRef]

BBC News. 2016. Nigeria officials 'stole \$15bn from anti-Boko Haram Fight. BBC News. May 3. Available online: https://www.bbc.com/news/world-africa-36192390 (accessed on 9 August 2019).

BBC News. 2019. Nigeria: 'Children used' as suicide bombers in Borno attack. BBC News, June 18.

Beck, Collin J. 2008. The contribution of social movement theory to understanding terrorism. Sociology Compass 2 : 1565-81. [CrossRef]

Bergesen, Albert J., and Omar Lizardo. 2004. International terrorism and the world-system. Sociological Theory 22: 38-52. [CrossRef]

Bloom, Mia. 2017. Constructing expertise: Terrorist recruitment and "talent spotting" in the PIRA, Al Qaeda, and ISIS. Studies in Conflict \& Terrorism 40: 603-23.

Brechenmacher, Saskia. 2019. Stabilizing Northeast Nigeria after Boko Haram". Carnegie Endowment for International Peace, May 3.

Brock, Joe. 2013. Insight: Boko Haram, Taking to Hills, Seize Slave 'Brides'. Reuters, November 17.

Brown, Velbab F. 2018. Nigeria's troubling counterinsurgency strategy against Boko Haram: How the military and militias are fueling insecurity. Foreign Affairs, March 30.

Campbell, John. 2013. Should US fear Boko Haram. CNN, October 1.

Campbell, John. 2018a. Boko Haram Faction Reportedly Collecting Taxes in Northeast Nigeria. Council on Foreign Relations, May 24.

Campbell, John. 2018b. Boko Haram overruns Nigerian Military base. Council on Foreign Relations, November 27.

Cannon, Brendon, and Wisdom Iyekekpolo. 2018. Explaining Transborder Terrorist Attacks: The Cases of Boko Haram and Al-Shabaab. African Security 11: 370-96. [CrossRef]

Chiluwa, Innocent. 2015. Radicalist discourse: A study of the stances of Nigeria's Boko Haram and Somalia's Al Shabaab on Twitter. Journal of Multicultural Discourses 10: 214-35. [CrossRef]

China Global Television Network. 2017. New Figures put Boko Haram Death Toll at 100,000, China Global Television Network. Available online: https:/www.youtube.com/watch?v=2uM9ppHmpk8 (accessed on 13 December 2018). 
Clarke, Collin P. 2015. Terrorism, Inc.: The Financing of Terrorism, Insurgency, and Irregular Warfare: The Financing of Terrorism, Insurgency, and Irregular Warfare. Santa Barbara: ABC-CLIO Publishers.

Clauset, Aaron, and Kristian Skrede Gleditsch. 2012. The Developmental Dynamics of Terrorist Organizations. PLoS ONE 7: e48633. [CrossRef]

Combs, Cynthia C. 2017. Terrorism in the Twenty-First Century. Abingdon-on-Thames: Routledge Publishers.

David, Ojochenemi J., Lucky E. Asuelime, and Hakeem Onapajo. 2015. Boko Haram: the socio-economic drivers. Switzerland: Springer International Publishing.

Del Vecchio, Giorgio. 2016. Political violence as shared terrain of militancy: Red Brigades, social movements and the discourse on arms in the early Seventies. Behavioral Sciences of Terrorism and Political Aggression 8: 212-26. [CrossRef]

Dietrich, Kyle. 2015. When We Can't See the Enemy, Civilians Become the Enemy: Living Through Nigeria's Six-Year Insurgency. Center for Civilians in Conflict. Available online: https://civiliansinconflict.org/wpcontent/uploads/2015/10/NigeriaReport_Web.pdf (accessed on 15 June 2019).

Dixon, Robyn. 2014. Young Women Used in Nigerian Suicide Bombings. Los Angeles Times, July 30.

Doherty, Ben. 2017. Climate Change will fuel Terrorism recruitment: Report for German Foreign Office says. The Guardian, April 19.

Donovan, Kevin P., Philippe M. Frowd, and Aaron K. Martin. 2016. ASR Forum on surveillance in Africa: Politics, histories, techniques. African Studies Review 59: 31-37. [CrossRef]

Dowd, Caitriona, and Adam Drury. 2017. Marginalisation, insurgency and civilian insecurity: Boko Haram and the Lord's Resistance Army. Peacebuilding 5: 136-52. [CrossRef]

DW News. 2019. Boko Haram: Nigeria Moves to Deradicalize Former Fighters. DW News. August 8. Available online: https://www.dw.com/en/boko-haram-nigeria-moves-to-deradicalize-former-fighters/a-49950707 (accessed on 15 August 2019).

Eke, Surulola James. 2015. How and why Boko Haram blossomed: Examining the fatal consequences of treating a purposive terrorist organisation as less so. Defense E Security Analysis 31: 319-29.

Ette, Mercy, and Sarah Joe. 2018. 'Rival visions of reality': An analysis of the framing of Boko Haram in Nigerian newspapers and Twitter. Media, War \& Conflict 11: 392-406.

European Commission. 2017. European Commission. 2017. Preventing Violent Extremism in Nigeria: Effective Narratives and Messaging. National Workshop Report. Available online: http://www.clubmadrid.org/wpcontent/uploads/2017/10/2.-Nigeria_Report.pdf (accessed on 21 January 2020).

Faria, João Ricardo, and Daniel G. Arce M. 2005. Terror support and recruitment. Defence and Peace Economics 16: 263-73. [CrossRef]

Faseke, Babajimi Oladipo. 2019. Nigeria and the Organization of Islamic Cooperation: A Discourse in Identity, Faith and Development, 1969-2016. Religions 10: 156. [CrossRef]

Federal Government Nigeria. 2011. Money Laundering (Prohibition) Act, 2011 (As Amended), Harmonized Act No. 11, 2011; Abuja: Federal Ministry of Justice.

Federal Government Nigeria. 2013. Central Bank of Nigeria (Anti-Money Laundering and Combating the Financing of Terrorism in Banks and other Financial Institutions in Nigeria) Regulations; Lagos: Federal Government Printer.

Felter, Claire. 2018. Nigeria's battle with Boko Haram. Council on Foreign Relations. August 8. Available online: https://www.cfr.org/backgrounder/nigerias-battle-boko-haram (accessed on 17 September 2019).

Fessy, Thomas. 2016. Boko Haram Recruits Were Promised Lots of Money. BBC News. March 25. Available online: https://www.bbc.com/news/av/world-africa-35898319/boko-haram-recruits-were-promised-lots-ofmoney (accessed on 5 July 2019).

Financial Action Task Force. 2016. Terrorist Financing in West Africa and Central Nigeria. FATF Report. Available online: https://www.fatf-gafi.org/media/fatf/documents/reports/Terrorist-Financing-West-Central-Africa.pdf (accessed on 27 June 2019).

Forest, James J. F., ed. 2006. The Making of a Terrorist: Recruitment, Training, and Root Causes. Santa Barbara: Praeger Security International.

Gaffey, Connor. 2016. Boko Haram's Business Model: Poor Nigerian Youths given Loans to join militant group. Newsweek, April 13.

Galehan, Jordan N. 2019. Boko Haram deploys lots of women suicide bombers. I found out why. The Conversation, June 13. 
Galtimari, Usman Gaji. 2011. Final Report of the Presidential Committee on Security Challenges in the North-East Zone of Nigeria. Abuja: Federal Government of Nigeria.

Gates, Scott, and Sukanya Podder. 2015. Social media, recruitment, allegiance and the Islamic State. Perspectives on Terrorism 9: 107-16.

Gentry, Caron. 2004. The Relationship between New Social Movement Theory and Terrorism Studies: The Role of Leadership, Membership, Ideology and Gender. Terrorism and Political Violence 16: 274-93. [CrossRef]

Gerretsen, Isabelle. 2019. How Climate Change is fueling extremism. CNN News, March 10.

GIABA. 2015. Seventh Follow Up Report Mutual Evaluation: Nigeria. Inter-Governmental Action Group against Money Laundering in West Africa. Available online: https://www.giaba.org/media/f/932_7th\%20FUR\% 20Nigeria\%20-\%20English.pdf (accessed on 28 June 2019).

Göpfert, Mirco. 2016. Surveillance in Niger: Gendarmes and the Problem of "Seeing Things". African Studies Review 59: 39-57. [CrossRef]

Gray, Simon, and Ibikunle Adeakin. 2015. The evolution of Boko Haram: From missionary activism to transnational jihad and the failure of the Nigerian security intelligence agencies. African Security 8: 185-211. [CrossRef]

Guadagno, Rosanna E., Adam Lankford, Nicole L. Muscanell, Bradley M. Okdie, and Debra M. McCallum. 2010. Social influence in the online recruitment of terrorists and terrorist sympathizers: Implications for social psychology research. Revue Internationale de Psychologie Sociale 23: 25-56.

Guilberto, Kieran. 2016. Boko Haram Lures, Traps Young Nigerian Entrepreneurs with Business Loans. Reuters, April 11.

Gulland, Anne. 2019. Climate Change and Insecurity: David Miliband warns of double threat in Lake Chad. The Telegraph, July 10.

Hairgrove, Frank, and Douglas M. Mcleod. 2008. Circles drawing toward high risk activism: The use of usroh and halaqa in Islamist radical movements. Studies in Conflict \& Terrorism 31: 399-411.

Hansen, William. 2017. Boko Haram: Religious radicalism and insurrection in northern Nigeria. Journal of Asian and African Studies 52: 551-69. [CrossRef]

Hashimu, Salaudeen, and Ancell James. 2017. Boko Haram feeds off corruption in Nigeria. Aljazeera, April 13.

Hentz, James J. 2018. The multidimensional nature of the Boko Haram conflict. Small Wars \& Insurgencies 29: 839-62.

Hill, Jonathan N. C. 2013. Religious Extremism in Northern Nigeria past and present: Parallels between the pseudo-Tijanis and Boko Haram. The Round Table 102: 235-44. [CrossRef]

Human Rights Watch. 2019. They Didn't Know if I Was Alive or Dead. Human Rights Watch Report. Available online: https://www.hrw.org/sites/default/files/report_pdf/nigeria0919_web.pdf (accessed on 7 September 2019).

Innocent, Eme Okechukwu. 2018. Inter-Security Agency Rivalry as an Impediment to National Counter Terrorism Strategy (NACTEST). Africa Heritage Report. Available online: https:/www.africaportal.org/publications/ inter-security-agency-rivalry-impediment-national-counter-terrorism-strategy-nactest/ (accessed on 21 January 2020).

Institute for Economics and Peace. 2015. Global Terrorism Index 2015. Institute for Economics and Peace. Available online: http://economicsandpeace.org/wp-content/uploads/2015/11/Global-Terrorism-Index-2015. pdf (accessed on 6 August 2019).

Institute for Economics and Peace. 2017. Global Terrorism Index 2017. Institute for Economics and Peace. Available online: http://visionofhumanity.org/app/uploads/2017/06/GPI17-Report.pdf (accessed on 6 August 2019).

Institute Economics Peace. 2018. Global Terrorism Index 2018. Institute for Economics and Peace. Available online: http://visionofhumanity.org/app/uploads/2018/12/Global-Terrorism-Index-2018--1.pdf (accessed on 6 August 2019).

International Crisis Group. 2016. Boko Haram Is Losing Ground but Will Not Be Defeated by Weapons Alone. Brussels: International Crisis Group. 
IOM UN Migration News. 2019. County Security Committees on Community Policing and Prevention of Violent Extremism. IOM UN Migration News. October 11. Available online: https://www.iom.int/ news/county-security-committees-community-policing-and-prevention-violent-extremism (accessed on 13 November 2019).

Iwuoha, Victor Chidubem. 2019. United States' Security Governance in Nigeria: Implications on Counterterrorism Strategies against Boko Haram. Journal of Asian and African Studies. [CrossRef]

Iyekekpolo, Wisdom Oghosa. 2016. Boko Haram: Understanding the context. Third World Quarterly 37: 2211-28. [CrossRef]

Iyekekpolo, Wisdom Oghosa. 2018. Political Elites and the Rise of the Boko Haram Insurgency in Nigeria. Terrorism and Political Violence, 1-19. [CrossRef]

Jones, Edgar. 2017. The reception of broadcast terrorism: Recruitment and radicalisation. International Review of Psychiatry 29: 320-26. [CrossRef]

Joosse, Paul, Sandra M. Bucerius, and Sara K. Thompson. 2015. Narratives and counternarratives: Somali-Canadians on recruitment as foreign fighters to Al-Shabaab. British Journal of Criminology 55: 811-32. [CrossRef]

Kenya News Agency. 2019. Enhancement of Security Attributed to Nyumba Kumi. Kenya News Agency. January 22. Available online: https://www.kenyanews.go.ke/enhancement-of-security-attributed-to-nyumba-kumi/ (accessed on 31 October 2019).

Klein, Graig R. 2016. Ideology isn't everything: Transnational terrorism, recruitment incentives, and attack casualties. Terrorism and Political Violence 28: 868-87. [CrossRef]

Knapton, Holly. 2014. The Recruitment and Radicalisation of Western Citizens: Does Ostracism Have a Role in Homegrown Terrorism? Journal of European Psychology Students 5: 38-48.

Kruglanski, Arie W., and Shira Fishman. 2009. What makes terrorism tick? Its individual, group and organizational aspects. Revista de Psicología Social 24: 139-62. [CrossRef]

Lake Chad Basin Commission News. 2019. MNJRF communicates. Lake Chad Basin Commission News. May 8. Available online: https://www.cblt.org/en/news/mnjtf-communicates (accessed on 19 July 2019).

Loimeier, Roman. 2012. Boko Haram: The development of a militant religious movement in Nigeria. Africa Spectrum 47: 137-55. [CrossRef]

MacEachern, S. 2018. Searching for Boko Haram: A History of Violence in Central Africa. Oxford: Oxford University Press.

Madonia, Salvatore, and Ana I. Planet Contreras. 2019. From the Mosque to the Town Square: Some Reflections on Islam, Youth, Social Movements and Citizenship. Religions 10: 180. [CrossRef]

Madugba, Agaju. 2015. Kano Emir Links Boko Haram to Social Media. Vanguard News, July 5.

Magrin, Géraud, and Marc-Antoine Pérouse De Montclos. 2018. Crisis and Development the Lake Chad Region and Boko Haram. Paris: Dila Publications.

Mahmood, Omar S., and Christian Ndubuisi Ani. Responses to Boko Haram in the Lake Chad Region: Policies, Cooperation and Livelihoods. Institute for Security Studies Research Report. Available online: https: //reliefweb.int/sites/reliefweb.int/files/resources/2018-07-06-research-report-1.pdf (accessed on 21 July 2019).

Maiangwa, Benjamin, Ufo Okeke Uzodike, Ayo Whetho, and Hakeem Onapajo. 2012. "Baptism by Fire": Boko Haram and the Reign of Terror in Nigeria. Africa Today 59: 41-57. [CrossRef]

Markovic, Vesna. 2019. Suicide squad: Boko Haram's use of the female suicide bomber. Women \& Criminal Justice 29: 283-302.

Martin, Aaron. 2018. House bill would Permanently Authorize Trans-Sahara Counterterrorism Partnership to Prevent Terrorism, Extremism in West Africa. Homeland Preparedness News. June 12. Available online: https://homelandprepnews.com/stories/28910-house-bill-permanently-authorize-trans-saharacounterterrorism-partnership-prevent-terrorism-extremism-west-africa/ (accessed on 7 September 2019).

Matfess, Hilary. 2016. Boko Haram Is Enslaving Women, Making Them Join the War. Newsweek. February 8. Available online: https://www.newsweek.com/nigeria-boko-haram-buhari-chibok-girls-424091 (accessed on 18 September 2019).

Matfess, Hilary. 2017. How Nigeria's Boko Haram Crackdown Harms Local Economies: Harsh Trade Restrictions Have Revived Smuggling. Foreign Affairs. July 17. Available online: https://www.foreignaffairs. com/articles/africa/2017--07--17/how-nigerias-boko-haram-crackdown-harms-local-economies (accessed on 18 July 2019). 
Mentan, Tatah. 2017. Dilemmas of Weak States: Africa and Transnational Terrorism in the Twenty-First Century. Abingdon-on-Thames: Routledge.

Mentone, Dario. 2018. The Counterterrorism framework in Nigeria: Strategic and Operational Pitfall: European Eye on Radicalization Report. Available online: https:/eeradicalization.com/the-counterterrorism-frameworkin-nigeria-strategic-and-operational-pitfalls/ (accessed on 28 June 2018).

Mercy Corps. 2016. Motivations and Empty Promises: Voices of Former Boko Haram Combatants and Nigerian Youth. Available online: https://www.mercycorps.org/sites/default/files/Motivations\%20and\%20Empty\% 20Promises_Mercy\%20Corps_Full\%20Report.pdf (accessed on 19 July 2019).

Michael Kpughe, Lang. 2017. Christian churches and the Boko Haram insurgency in Cameroon: Dilemmas and Responses. Religions 8: 143. [CrossRef]

Munshi, Neil. 2018. Why Nigeria is Struggling to Defeat Boko Haram. Financial Times. December 10. Available online: https://www.ft.com/content/62928c8e-f7b8--11e8--8b7c-6fa24bd5409c (accessed on 18 July 2019).

Murtada, Ahmad. 2013. Boko Haram in Nigeria: Its Beginnings, Principles and Activities in Nigeria. Available online: http://download.salafimanhaj.com/pdf/SalafiManhaj_BokoHaram.pdf (accessed on 16 June 2019).

Nche, George C., Chikodi Wachukwu, Chinyere T. Nwaoga, Ekene M. Mokwenye, Prince Agwu, and Daniel I. Alagboso. 2019. We Sleep with One Eye Open: Exploring the Experiences of Churches in Rivers State, Nigeria. Journal of Asian and African Studies. [CrossRef]

Ndono, Phyllis Wamaitha, Nzioka John Muthama, and Kariuki Muigua. 2019. Effectiveness of the Nyumba Kumi community policing initiative in Kenya. Journal of Sustainability, Environment and Peace 1: 63-67.

Nduka, Chiejina. 2019. Boko Haram Fighters Paid \$3000 Daily, Says Presidential Committee. The Nation. April 30. Available online: https://thenationonlineng.net/boko-haram-fighters-paid-3000-daily-says-presidentialcommittee/ (accessed on 7 August 2019).

Neumann, Peter R. 2012. Joining Al-Qaeda: Jihadist Recruitment in Europe. Abingdon-on-Thames: Routledge.

News Express. 2015. Boko Haram Suffers Heavy Defeat in Surprise Attack on Military Base. News Express. January 5. Available online: https://www.newsexpressngr.com/news/detail.php?news=8954 (accessed on 19 July 2019).

Newton, Allen. 2011. The 'Talking Cure': Intelligence, Counter-Terrorism Doctrine and Social Movements. Intelligence and National Security 26: 120-31. [CrossRef]

Nigeria Watch. 2019. Eight Report on Violence in Nigeria. Nigeria Watch 2018 Report. Available online: http://www.nigeriawatch.org/media/html/NGA-Watch-Report18V4.pdf (accessed on 14 June 2019).

Nigerian Financial Intelligence Unit. 2018. Nigerian Financial Intelligence Unit Act 2018. Available online: https: //placng.org/wp/wp-content/uploads/2018/07/Nigerian-Financial-Intelligence-Unit-Act-2018.pdf (accessed on 23 December 2018).

Nigerian Tribune. 2019. Army needs Spiritual Help to Defeat Boko Haram-Buratai. Nigerian Tribune. September 30. Available online: https://tribuneonlineng.com/army-needs-spiritual-help-to-defeat-boko-haram-\%E2\% 80\%95-buratai/ (accessed on 7 November 2019).

Nnodim, Okechukwu, and Aluko Olaleye. 2017. Boko Haram Attack: DHQ Fingers Informants, Blames Weather for Killings. Punch News. August 1. Available online: https://punchng.com/bharam-attack-dhq-fingersinformants-blames-weather-for-killings/ (accessed on 13 August 2019).

Nwaubani, Adaobi Tricia. 2017. Letter from Africa: Freed Boko Haram 'Wives' Return to Captors. BBC News. July 26. Available online: https://www.bbc.com/news/world-africa-40704569 (accessed on 18 July 2019).

Nwaubani, Adaobi Tricia. 2019. Why Boko Haram Captured the Chibok Girls. The News. October 27. Available online: https://www.thenewsnigeria.com.ng/2019/10/27/why-boko-haram-captured-the-chibok-girls-adaobitricia-nwaubani/ (accessed on 21 November 2019).

Obamamoye, Babatunde F. 2019. State Weakness and Regional Security Instability: Evidence from Africa's Lake Chad Region. International Journal of Conflict and Violence 13: 639.

Ogunmade, Omololu, and Michael Olugbode. 2017. FG Launches Action Plan to Prevent Counter Terrorism. This Day News. November 27. Available online: https://www.thisdaylive.com/index.php/2017/11/29/fglaunches-action-plan-to-prevent-counter-terrorism/ (accessed on 19 June 2019).

Olojo, Akinola E. 2015. Boko Haram insurgency in Nigeria: Between Islamic fundamentalism, politics, and poverty. African Security 8: 1-29.

Olojo, Akinola E. 2017. Resistance through Islamic Clerics against Boko Haram in Northern Nigeria. African Security Review 26: 308-24. [CrossRef] 
Olojo, Akinola E. 2019. Dialogue with Boko Haram back on the agenda? Institute for Security Studies. July 2. Available online: https://issafrica.org/iss-today/dialogue-with-boko-haram-back-on-the-agenda (accessed on 19 August 2019).

Omenma, J. Tochukwu. 2019. Untold Story of Boko Haram Insurgency: The Lake Chad Oil and Gas Connection. Politics and Religion 13: 1-34. [CrossRef]

Onapajo, Hakeem, and Ufo Okeke Uzodike. 2012. Boko Haram Terrorism in Nigeria: Man, the state, and the international system. African Security Review 21: 24-39. [CrossRef]

Onuoha, Freedom C. 2012. The audacity of the Boko Haram: Background, analysis and emerging trend. Security Journal 25: 134-51. [CrossRef]

Onuoha, Freedom C. 2014a. A Danger Not to Nigeria Alone: Boko Harams's Transnational Reach and Regional Responses. Abuja: Friedrich Ebert Stifung.

Onuoha, Freedom C. 2014b. Why Do Youth Join Boko Haram? Washington: US Institute of Peace.

Oriola, Temitope B. 2017. "Unwilling Cocoons": Boko Haram's War against Women. Studies in Conflict E Terrorism 40: 99-121.

Ortbals, Candice D., and Lori Poloni-Staudinger. 2014. Women defining terrorism: Ethnonationalist, state, and machista terrorism. Critical Studies on Terrorism 7: 336-56. [CrossRef]

Oyewole, Samuel. 2015. Boko Haram: Insurgency and the war against terrorism in the Lake Chad region. Strategic Analysis 39: 428-32. [CrossRef]

Özeren, Süleyman, Murat Sever, Kamil Yilmaz, and Alper Sözer. 2014. Whom do they recruit? Profiling and recruitment in the PKK/KCK. Studies in Conflict \& Terrorism 37: 322-47.

Pham, J. Peter. 2016. Boko Haram: The strategic evolution of the Islamic State's West Africa Province. The Journal of the Middle East and Africa 7: 1-18. [CrossRef]

Pieri, Zacharias P. 2019. Boko Haram and the Drivers of Islamist Violence. London: Routledge.

Pieri, Zacharias P., and Jacob Zenn. 2016. The Boko Haram paradox: ethnicity, religion, and historical memory in pursuit of a caliphate. African Security 9: 66-88. [CrossRef]

Pieri, Zacharias P., and Jacob Zenn. 2018. Under the Black Flag in Borno: Experiences o foot soldiers and civilians in Boko Haram's 'caliphate'. The Journal of Modern African Studies 56: 645-72. [CrossRef]

Post, Jerrold M., Keven G. Ruby, and Eric D. Shaw. 2002. The radical group in context: 1. An integrated framework for the analysis of group risk for terrorism. Studies in Conflict and Terrorism 25: 73-100. [CrossRef]

Premium Times. 2017a. Economic Impact of Boko Haram in Nigeria's North East now \$9billion-Buratai. Premium Times. August 11. Available online: https://www.premiumtimesng.com/news/more-news/239927economic-impact-boko-haram-nigerias-north-east-now-9billion-buratai.html (accessed on 18 July 2019).

Premium Times. 2017b. Boko Haram Destroyed One Million Houses, 5,000 Classrooms, N1. 9 Trillion Properties in Borno-Official. Premium Times. August 8. Available online: https://www.premiumtimesng.com/regional/nnorth-east/239645-boko-haram-destroyed-onemillion-houses-5000-classrooms-n1-9-trillion-properties-borno-official.html (accessed on 18 July 2019).

Premium Times. 2018. UN Highlights Alarming Trends in Drug Us, Trafficking in Nigeria, Others. Premium Times. December 20. Available online: https://www.premiumtimesng.com/news/headlines/302074-un-highlightsalarming-trends-in-drug-use-trafficking-in-nigeria-others.html (accessed on 14 July 2019).

Premium Times. 2019. Buratai Seeks Religious Leaders Support in Eradicating Terrorists Ideologies. Premium Times. September 30. Available online: https://www.premiumtimesng.com/news/top-news/355198-burataiseeks-religious-leaders-support-in-eradicating-terrorists-ideologies.html (accessed on 18 October 2019).

Prud'homme, Joseph. 2019. Security, Religion, and Political Culture: A Defense of Weak Disestablishment. Religions 10: 88. [CrossRef]

Punch News. 2016. Buhari Inaugurates Presidential Committee on North East Initiative. Punch News. October 26. Available online: https://punchng.com/buhari-inaugurates-presidential-committee-north-east-initiative-fullspeech/ (accessed on 19 July 2019).

Punch News. 2017. Economic Impact of Boko Haram in North East estimated at N274.5bn. Punch News. August 10. Available online: https://punchng.com/economic-impact-of-boko-haram-in-northeast-estimated-at-n274$5 \mathrm{bn} /$ (accessed on 17 July 2019).

Ranstorp, Magnus, ed. 2006. Mapping Terrorism Research: State of the Art, Gaps and Future Direction. Abingdon-on-Thames: Routledge. 
Rasak, Bamidele. 2018. Fundamentalism, Boko Haram Movement and Socio-Economic Development in North-Eastern Zone of Nigeria. The Nigerian Journal of Sociology and Anthropology 16: 93-111.

Reuters. 2011. Nigerian sect says killed journalist for spying. Reuters. October 25. Available online: https: //www.reuters.com/article/ozatp-nigeria-sect-idAFJOE79O05K20111025 (accessed on 19 July 2019).

Rufai, Saheed Ahmad. 2017. Boko Haram and Its Modalities of Recruiting and Radicalizing Members. Peace Review 29: 199-206. [CrossRef]

Sahara Reporters. 2013. BREAKING NEWS: Jonathan Declares State of Emergency in Borno, Yobe and Adamawa State. Sahara Reporters. May 14. Available online: http://saharareporters.com/2013/05/14/breaking-newsjonathan-declares-state-emergency-borno-yobe-and-adamawa-state (accessed on 16 August 2019).

Sahara Reporters. 2019. Boko Haram Still Collecting Taxes, Providing Services in Borno-Archbishop of Kaduna. Sahara Reporters. June 19. Available online: http://saharareporters.com/2019/06/19/ boko-haram-still-collecting-taxes-providing-services-borno- $\%$ E2\%80\%93archbishop-kaduna (accessed on 18 September 2019).

Salifu, Uyo, and Martin Ewi. 2017. Boko Haram and Violent Extremism: Perspective from Peacebuilders. Policy Brief 97. Institute for Security Studies. Available online: https://frantic.s3-eu-west-1.amazonaws.com/kuapeacemakers/2016/07/Boko-Haram-and-Violent-Extremism-Perspectives-from-Peacebuilders.pdf (accessed on 13 June 2019).

Salkida, Ahmad. 2019. SPECIAL REPORT: Why Troops Are Losing Ground to ISWAP. Sahara Reporters. January 2. Available online: http://saharareporters.com/2019/01/02/special-report-why-troops-are-losing-ground-iswap (accessed on 17 April 2019).

Sambaiga, Richard F. 2018. Changing images of Nyumba Kumi in Tanzania: Implications for youth engagement in countering violence at community level. The African Review 45: 49-74.

Sampson, Isaac Terwase. 2016. The dilemmas of counter-bokoharamism: Debating state responses to Boko Haram terrorism in northern Nigeria. Security Journal 29: 122-46. [CrossRef]

Samuel, Malik. 2019. The Economics of Terrorism in the Lake Chad Basin. Institute of Security Studies Report. July 10. Available online: https://issafrica.org/iss-today/economics-of-terrorism-in-lake-chad-basin (accessed on 1 October 2019).

Sarjoon, Athambawa, Mohammad Agus Yusoff, and Nordin Hussin. 2016. Anti-Muslim sentiments and violence: A major threat to ethnic reconciliation and ethnic harmony in post-war Sri Lanka. Religions 7: 125. [CrossRef]

Searcey, Dionne, and Akinwotu Emmanuel. 2019. Nigeria Election Brings Dual Crisis Back to Polls: Corruption and Boko Haram. The New York Times. February 11. Available online: https://www.nytimes.com/2019/02/11/ world/africa/nigeria-election-corruption.html (accessed on 10 November 2019).

Shannon, Deric Michael. 2011. Making Culture: Social Movements, Culture, and Food Not Bombs. Doctoral dissertation. AAI3476612. Available online: https://opencommons.uconn.edu/dissertations/AAI3476612/ (accessed on 19 June 2019).

Sigelmann, Laura. 2019. Lake Chad Remains Stable, Yet Boko Haram Still Thrives Part 2: The Extremists. American Security Project. June 14. Available online: https://www.americansecurityproject.org/lake-chad-remainsstable-yet-boko-haram-still-thrives-part-2/ (accessed on 13 October 2019).

Slutzker, Jillian. 2018. The Online Frontline: Inside Boko Haram's Social Media and A Movement to Push Back. Creative. October 10. Available online: https://www.creativeassociatesinternational.com/ stories/the-online-frontline-inside-boko-harams-social-media-and-the-movement-to-push-back/ (accessed on 14 November 2019).

Smith, Sam. 2016. Q\&A-The Lake Chad crisis explained. British Red Cross, October 31.

Smith, Claire, Rosslyn Von Der Borch, Benjamin Isakhan, ukendar, Priyambudi Sulistiyanto, Ian Ravenscrroft, Ida Widianingsih, and Cherrie De Leiuen. 2018. The manipulation of social, cultural and religious values in socially mediated terrorism. Religions 9: 168. [CrossRef]

Solomon, Salem. 2017. Report: Corruption in Nigerian Military Benefits Boko Haram. Voice of America. May 19. Available online: https://www.voanews.com/africa/report-corruption-nigerian-military-benefitsboko-haram (accessed on 25 April 2019).

START. 2018. Global Terrorism Database. Available online: https://www.start.umd.edu/gtd/search/Results.aspx? chart=weapon\&search=boko\%20haram (accessed on 17 August 2019). 
Swails, Brent, and Mckenzie David. 2016. Kidnapped to Kill: Boko Haram is Turning Girls into Weapons. CNN. April 13. Available online: https://edition.cnn.com/2016/04/12/africa/cameroon-boko-haram-child-bombers/ index.html (accessed on 12 April 2019).

The Guardian News. 2015. Boko Haram has up to 6000 'Hardcore' Fighters, Claims US Intelligence. The Guardian News. February 6. Available online: https://www.theguardian.com/world/2015/feb/06/boko-haram-up-to6000-hardcore-fighters-chad-niger (accessed on 21 July 2019).

Torbjornsson, Daniel, and Jonson Michael. 2017. Boko Haram: On the Verge or a Long Term Threat? FOI Report 4488. Available online: https:/www.google.com/url?sa=t\&source=web\&rct=j\&url=https: //www.foi.se/rest-api/report/FOI-R--4488--SE\&ved=2ahUKEwjon6a9o97nAhXUbsAKHYW7C_ 4QFjABegQIBRAB\&usg=AOvVaw0KCDw-HfijYB-6nooEJZws (accessed on 19 April 2019).

TRT World News. 2018. Fighting Boko Haram: ‘Peace Clubs' Counter group through Education. TRT World News. October 13. Available online: https://www.trtworld.com/video/news-videos/fighting-boko-haram-peaceclubs-counter-group-through-education/5bc19985315f18291a6c6337 (accessed on 12 October 2019).

Tukur, Sani. 2017. Shocking Revelation: 100,000 Killed, Two Million Displaced by Boko Haram Insurgency, Borno Governor Says. Premium Times. February 13. Available online: https://www.premiumtimesng.com/news/headlines/223399-shocking-revelation-100000-killed-twomillion-displaced-boko-haram-insurgency-borno-governor-says.html (accessed on 13 June 2019).

Umar, Muhammad Sani. 2012. The popular discourses of Salafi radicalism and Salafi counter-radicalism in Nigeria: A case study of Boko Haram. Journal of Religion in Africa 42: 118-44.

Umar, Aminu M. 2013. Nigeria and the Boko Haram Sect: Adopting a Better Strategy for Resolving the Crisis. Monterey: Naval Postgraduate School.

Umukoro, Nathaniel. 2016. Thermodynamics: Application of its Principles to the Effects of Cross-Border Migration and Boko Haram Crisis on Security Challenges in Africa. Journal of Applied Security Research 11: 44-60. [CrossRef]

UNDP. 2017. A tool for terrorism: Exploring how ISIL, al-Shabaab and Boko Haram use Social Media in Africa. United Nations Development Programme. UNDP Report. Available online: https://www.undp.org/content/ dam/rba/docs/Reports/UNDP-RAND-SOcialMediaAFrica-Research\%20Brief_final_3\%20Oct.pdf (accessed on 16 August 2019).

United Nations. 2018. Better Governance of Underfunded, Poorly Managed Lake Chad Basin Key to Resolving Conflict, Suffering across Region, Speakers Tell Security Council. United Nations Security Council. Briefing No. SC/13259. March 22. Available online: https://www.un.org/press/en/2018/sc13259.doc.htm (accessed on 13 September 2019).

United Nations News. 2018. Nigerian President calls for global action on climate change, Lake Chad crisis. United Nations News. September 25. Available online: https://news.un.org/en/story/2018/09/1020612 (accessed on 13 September 2019).

UNODC. 2017. The Drug problem and Organized Crime, Illicit Financial Flows, Corruption and Terrorism. United Nations Office on Drugs and Crime. World Drug Report. Available online: https://www.unodc.org/wdr2017/ index.html (accessed on 11 November 2018).

Vivekananda, Janani, Martin Wall, Florence Sylvestre, and Chitra Nagarajan. 2019. Shoring up Stability: Addressing Climate and Fragility Risks in the Lake Chad Region. Adelphi Report. Available online: https: //shoring-up-stability.org/wp-content/uploads/2019/06/Shoring-up-Stability.pdf (accessed on 26 July 2019).

Voll, John. 2015. Boko Haram: Religion and Violence in the 21st Century. Religions 6: 1182-202. [CrossRef]

Walker, Andrew. 2016. Join us or Die: The Birth of Boko Haram. The Guardian. February 4. Available online: https:/www.theguardian.com/world/2016/feb/04/join-us-or-die-birth-of-boko-haram (accessed on 12 August 2019).

Weeraratne, Suranjan. 2017. Theorizing the expansion of the Boko Haram Insurgency in Nigeria. Terrorism and Political Violence 29: 610-34. [CrossRef]

Weimann, Gabriel. 2016. The Emerging Role of Social Media in the Recruitment of Foreign Fighters. In Foreign Fighters under International Law and Beyond. Edited by De Guttry Andrea, Francesca Capone and Christophe Paulussen. The Hague: TMC Asser Press, pp. 77-95.

Zenn, Jacob. 2013a. Boko Haram Recruitment Strategies. Council on Foreign Relations. Available online: https://www.cfr.org/blog/boko-haram-recruitment-strategies (accessed on 14 June 2019).

Zenn, Jacob. 2013b. Boko Haram's international connections. CTC Sentinel 6: 7-13. 
Zenn, Jacob. 2018. Boko Haram's conquest for the Caliphate: How Al Qaeda helped Islamic State acquire territory. Studies in Conflict E Terrorism, 1-34. [CrossRef]

Zenn, Jacob. 2019. Confronting Jihadist Factions in Nigeria: An Antidote for Defeatism. War on the Rocks. July 17. Available online: https://warontherocks.com/2019/07/confronting-jihadist-factions-in-nigeria-an-antidote-todefeatism/ (accessed on 1 September 2019).

Zenn, Jacob, Atta Barkindo, and Nicholas A. Heras. 2013. The Ideological Evolution of Boko Haram in Nigeria: Merging Local Salafism and International Jihadism. The RUSI Journal 158: 46-53. [CrossRef]

Zirima, Elvina. 2018. Nigeria-Displacement Report XXIII. Displacement Matrix Report. Available online: http://www.globaldtm.info/nigeria-displacement-report-xxiii-may-2018/ (accessed on 27 September 2019).

(C) 2020 by the authors. Licensee MDPI, Basel, Switzerland. This article is an open access article distributed under the terms and conditions of the Creative Commons Attribution (CC BY) license (http://creativecommons.org/licenses/by/4.0/). 
Article

\title{
Why Is There So Little Shia-Sunni Dialogue? Understanding the Deficit of Intra-Muslim Dialogue and Interreligious Peacemaking
}

\author{
Dino Krause ${ }^{1,2, *,+}$, Isak Svensson ${ }^{1}$ and Göran Larsson ${ }^{3}$ \\ 1 Department of Peace and Conflict Research, Uppsala University, 75120 Uppsala, Sweden; \\ Isak.Svensson@pcr.uu.se \\ 2 Danish Institute for International Studies, Østbanegade 117, 2100 Copenhagen, Denmark \\ 3 Department of Literature, History of Ideas, and Religion, University of Gothenburg, 40530 Göteborg, \\ Sweden; goran.larsson@lir.gu.se \\ * Correspondence: dikr@diis.dk \\ + Earlier versions of this paper have been presented at the research workshops "Islamist Armed Conflicts and \\ the Prospects for Conflict Resolution," 28-30 September 2018, Schwarzenberg, Switzerland, and "Sunni-Shia \\ Relations in Europe: How to Study Them?", 13-14 December 2018, Turku, Finland.
}

Received: 29 August 2019; Accepted: 30 September 2019; Published: 4 October 2019

\begin{abstract}
Despite a growth in fatalities resulting from organized violence with Shia-Sunni dimensions over the last two decades, in this study, we show, using existing data-bases on interreligious dialogue and peacemaking, that only less than two percent of the interreligious peacemaking organizations in the world are specialized in dialogue between Shias and Sunnis. Why is there so little institutionalized Shia-Sunni dialogue occurring when the need for such dialogue is evident? This study identifies and discusses this lack of institutional initiatives designed to prevent violence, manage conflicts and facilitate processes of intra-Muslim de-sectarianization. We discuss what we see as the three seemingly most obvious explanations-(1) the dismissal of the relevance of a Shia-Sunni cleavage, (2) the inappropriateness of the interreligious dialogue concept in the Muslim context, and (3) the substitution of institutional interreligious dialogue by other channels. Although we suggest that the third is the most potent explanation to pursue, we do not aim to provide a comprehensive explanation for the Shia-Sunni religious dialogue deficit. Instead, our aspiration is mainly to present and substantiate a puzzle that has not been identified or discussed in previous research. This can set an agenda for a reinvigorated research endeavor into the contemporary challenges for interreligious peacemaking.
\end{abstract}

Keywords: interreligious dialogue; interreligious peacemaking; Civil War; organized violence; Sunni; Shia; sectarianism; Middle East; regional power struggle

\section{Introduction}

Violence and conflicts across the Shia-Sunni divide have increased during the last decades. In fact, a disproportionate share of battle-related deaths falls upon armed conflicts that occur along the Shia-Sunni fault line (Finnbogason et al. 2019). Previous research has demonstrated how the increase of violent identity politics, by political elites and authoritarian leaders in the Middle East, but also in other parts of the wider Muslim world, has reactivated intra-Muslim tensions that had laid dormant (Abdo 2017; Byman 2014; Hinnebusch 2016; Larsson 2016). A well-established scholarly consensus recognizes that tensions between Shia and Sunni communities are not cases of primordial "ancient hatred" but rather that recently, these historical group identities have been instrumentalized by various political actors to maximize political gains and influence (Ahmed 2011; Behuria 2004; Hasheemi and Postel 2017; Nasr 2007; Wehrey 2017). The Shia and Sunni communities can be seen as what Benedict 
Anderson labeled "imagined communities," a concept that was originally developed to describe the socio-cultural construction of nationalism (Anderson 2006). In the Middle East, the regional rivalry between Saudi Arabia and Iran has been crucial in fomenting sectarian tensions, as their governments have utilized identity politics as measures to improve dominance and influence in a multi-sectarian region (Salloukh 2017). Moreover, the so-called Islamic State (IS) has carried out a brutal campaign against Shia Muslims across several countries outside the Middle East. Although the Shia-Sunni rift is only one divide in a region plagued by many multi-layered social conflicts (Phillips and Valbjørn 2018), it has risen to become the main identity cleavage in the Middle East: "Today, although there are myriad sects and forms of religious identity in the Middle East, the overarching intra-Islamic Shi'a-Sunni divide is the 'master cleavage' [ ... ]" (Sisk 2017, p. 266).

However, relatively little scholarly attention has been paid to contemporary institutional attempts to bridge this divide. We do not wish to add to the vast amount of research on the causes of conflict, but rather focus on their management. Our study builds upon what we identify as the puzzle of the Shia-Sunni interreligious dialogue deficit in contemporary politics. While the UN and other major international organizations have made dialogue, mediation, and peacebuilding efforts in some of the most violent conflicts with a Shia-Sunni dimension, organizations specialized in interreligious dialogue and peacemaking have yet to play a role here. As we will show in this article, although there are some historical examples of dialogue between Sunni and Shia Muslims from the 20th century, these initiatives are no longer active. Thus, we do not know how, and to what extent, interreligious dialogue and peacemaking occur across the Shia-Sunni divide.

A note on the terminology and scope of this study is needed before we proceed. There is no consensus as to what exactly terms such as "interreligious peacemaking," "interreligious dialogue," or "interfaith cooperation" capture. For instance, Cheetham et al. $(2013$, p. 1) criticize that many authors use the terms "interreligious dialogue" and "interreligious relations" interchangeably, ignoring the fact that they capture different things. The authors view dialogue as one form of relational engagement within the field of interreligious relations. Cornille and Corigliano $(2012$, p. 1) define interreligious dialogue as a category that implies "the engagement between different religious traditions oriented toward mutual understanding and growth." Accordingly, Cornille (2013, p. xii) distinguishes interreligious dialogue from other forms of interreligious interaction, such as neutral religion studies, or traditional apologetics, as a form of "constructive engagement between religious traditions."

Here, we examine interreligious peacemaking attempts to bridge the Shia-Sunni divide, incorporating but not limiting our attention to interreligious dialogue. Instead, we look more specifically at the institutional perspective: interreligious peacemaking initiatives tailored to conflicts between Shias and Sunnis. Nonetheless, more research is needed to shed light upon existing local strategies to foster dialogue between Shias and Sunnis in violent conflicts.

By exploring intra-Muslim sectarian tensions, peacemaking across the Shia-Sunni divide, and challenges for religious identity politics, our study aims to set an agenda for a reinvigorated research endeavor into the contemporary challenges for interreligious peacemaking and dialogue. As sectarian tensions between Shias and Sunnis can be locally anchored but also transcend existing national boundaries, there is a regional perspective to Shia-Sunni tensions. Besides this dimension, future research should also consider the question of time, i.e., when do conflicts occur and under what conditions are Shia-Sunni divisions utilized, and when do they cease to have a rationale for spurring continued conflicts.

We seek to contribute to the development of a research agenda for how to address the puzzle of the Shia-Sunni peacemaking deficit. After situating the latter against a backdrop of increasing levels of violence that have included a sectarian dimension, this article proceeds by discussing what we consider to be the three most potent potential hypotheses for how this puzzle may be understood. First, we discuss the possibility that Shia-Sunni dialogue does not exist because Shia-Sunni tensions are epiphenomenal and there is, in essence, no Shia-Sunni divide to bridge in the first place. Second, we discuss whether the lack of Shia-Sunni dialogue is simply a reflection of interreligious dialogue, 
as such, being a Western, Christian innovation that carries little weight in the Middle East and the wider Muslim world. Third, we discuss the possibility that the apparent lack of Shia-Sunni dialogue can be explained by arguing that dialogue and peacemaking occur through other institutional channels or informally through local actors, for example tribal leaders, village elders, or other local authorities. Of these three explanations, our analysis suggests that the third and last is most promising and warrants further attention. By examining these three hypotheses, we take the historical trajectory of Shia-Sunni "ecumenical" developments into account, as well as the track record of the intergovernmental approaches to conflicts across this divide and how the divide has been shaped by the inter-state rivalry between Iran and Saudi Arabia and their proxy wars in the Middle East. While this study aims to set a research agenda, by identifying and discussing what we argue to be an under-studied and little noted puzzle of a lack of institutional attempts to engage in interreligious dialogue in Shia-Sunni conflicts, we do not aspire to provide the full answer to solve this puzzle. Our discussion around the potential explanations should be seen as explorative, and the hypotheses are not necessarily mutually exclusive. The exploration of these potential explanations may hopefully enlighten further discussion and pave the way for a closer examination as to why there is so little institutional religious dialogue along the Shia-Sunni dimension, when the need for such dialogue is, as we suggest, evident.

\section{Presenting the Puzzle: The Deficit of Shia-Sunni Dialogue}

\subsection{The Increasing Levels of Violence with Shia-Sunni Dimensions}

Before discussing three hypotheses about what could help explain the apparent lack of Shia-Sunni dialogue, it is important to illustrate why we consider such dialogue to be necessary in the first place. Haddad $(2014,2017)$ has criticized what he describes as an indifferent and inflationary use of the term "sectarianism" in the regional context of the Middle East. In particular, he highlights the common failure to distinguish between the social, political, and religious dimensions that can create tensions between Shia and Sunni communities. Against this background, our study departs from the recognition that violence across the Shia-Sunni divided has increased substantially over time. Finnbogason et al. (2019) provide a conceptual framework of different sectarian dimensions of armed conflicts. Their empirical analysis, which builds upon the Religion and Armed Conflict (RELAC) dataset (Svensson and Nilsson 2018) on the religious dimensions of state-based conflict, as well as the Uppsala Conflict Data Program (UCDP) on one-sided violence (Eck and Hultman 2007) and non-state conflicts (Sundberg et al. 2012), demonstrates how levels of violence with different Shia-Sunni dimensions have increased over the last two decades. The authors distinguish between three dimensions of Shia-Sunni conflict: an identity-dimension, an alliance dimension, and an ideological (explicitly sectarian) dimension. Since 2014, an increasing number of fatalities has occurred in conflicts that share at least two such Shia-Sunni dimensions, and a notable share of these fatalities occurred in conflicts that shared all three Shia-Sunni dimensions (Finnbogason et al. 2019, p. 45). In other words, armed conflicts with multiple Shia-Sunni conflict dimensions have become increasingly violent in recent years.

In general, although armed conflicts with Shia-Sunni dimensions are relatively rare, if compared to the overall number of armed conflicts, their share of fatalities in organized violence has increased dramatically over the past decade: since 2011, the share of fatalities in organized violence with at least one Shia-Sunni identity dimension, of the total number of all fatalities in organized violence worldwide, lay at least above 40 percent (Finnbogason et al. 2019, p. 42). To a substantial extent, this high share can be explained by the Syrian Civil War, which includes multiple Shia-Sunni dimensions, as well as the growth of the so-called Islamic State and its violent campaign against Shia Muslims in several countries around the globe. Still, organized violence with Shia-Sunni dimensions also occurred elsewhere, for instance between tribal groups in Pakistan, and in the context of the ongoing civil war in Yemen (Finnbogason et al. 2019). Thus, although it should be noted that much of the organized violence with Shia-Sunni dimensions can be traced back to other contentious issues that may be partly 
overlapping with sectarian questions, the empirical trajectory of armed conflicts in the Middle East and parts of the wider Muslim world substantiates the claim that the Shia-Sunni divide constitutes a prominent cleavage in contemporary conflicts and that it has become increasingly militarized during the last decade.

Peacebuilding and dialogue are always a challenge in identity-based conflicts that have become militarized (Cox et al. 2017), but they might be even more so if they involve Shia-Sunni dimensions due to a number of complicating factors. The religious dimension to the conflicts transcends state borders, which creates a set of complex interactions between local political dynamics and transnational power relations. The local dynamics typically include the strategic instrumentalization of sectarian identities by authoritarian governments as well as the introduction of majority-based semi-democratic systems. The latter has, in these contexts, often led to ethnic and sectarian-based electoral mobilization, which further intensified ongoing cycles of violence (Sisk 2017, p. 260). In addition, high-level peacebuilding efforts are often undermined by regional powers that compete over strategic influence in the region, most importantly Iran and Saudi Arabia. However, despite the multifold challenges and the complexity of peacebuilding in conflicts with Shia-Sunni dimensions, the literature on identity-based conflicts has suggested several ways in which peacebuilding can work to effectively manage sectarian conflict and enhance social cohesion. Examples of successful peacebuilding efforts in sectarian conflicts include the cases of Northern Ireland, Bosnia, or Sri Lanka (Sisk 2017). As recognized by previous research, the building of peace and social cohesion "requires progress in extending the presence of an inclusive, resilient, and responsive state-especially at the local level" (Sisk 2017, p. 274; see also Cox et al. 2014). In other words, although these conflicts provide particular challenges, their complexity should not by itself explain the lack of peacebuilding initiatives and interreligious dialogue, which we empirically outline in the following section.

\subsection{The Low Levels of Institutional Peacemaking Dialogue along the Shia-Sunni Fault Line}

If we explore existing databases on interreligious dialogue and peacemaking, we find that the prevalence of organized violence across the Shia-Sunni divide is not reflected in a similar prevalence of institutional attempts for dialogue and peacemaking. The most comprehensive list of international organizations engaged in interreligious dialogue and peacemaking is provided by the King Abdullah Bin Abdulaziz International Centre for Interreligious and Intercultural Dialogue (KAICIID) and is called the KAICIID Peace Map. It identifies 463 internationally operating organizations that are specialized in interreligious dialogue and peacemaking (KAICIID 2018). For this study, we have coded the religious communities targeted by the interreligious dialogue initiatives of these organizations, based on the information in the original dataset. ${ }^{1}$ Table 1 provides an overview of our coding, displaying the most common interreligious relations addressed by peacemaking organizations listed in the KAICIID Peace Map. As can be seen in Table 1, only eight of these organizations (or 1.7 percent) have Shia-Sunni dialogue as an explicit mandate and/or have had concrete programs aimed at creating dialogue across the Shia-Sunni divide. By far the largest number of organizations addresses relations between Christian and Muslim communities, although still one hundred organizations address Christian-Jewish and Jewish-Muslim relations, respectively. In fact, it is worthwhile to mention that there are many organizations that specialize in relations between all the three Abrahamic religions. This is the case for 70 organizations.

1 Our coding is based on the following variables provided in the original dataset, for every of the 463 organizations: "IRDActivities" (Column Q), "Activities" (S), "Aim" (AB), "IRDdefinition" (AC), "Events" (AD), and "Publications: (AE). We examined whether an organization worked to address a certain form of interreligious relations, for example, Christian-Muslim, Intra-Muslim, Intra-Christian, etc. The Peace Map with our additional coding can be accessed under the link that is listed under Supplementary Materials. The variables that we have coded ourselves can be found in columns AJ to $\mathrm{BB}$. 
Table 1. Type of interreligious dialogue promoted by organizations in King Abdullah Bin Abdulaziz International Centre for Interreligious and Intercultural Dialogue (KAICIID) Peace Map ${ }^{1}$.

\begin{tabular}{ccc}
\hline $\begin{array}{c}\text { Type of Interreligious Dialogue } \\
\text { Promoted by Organizations }\end{array}$ & $\begin{array}{c}\text { Number of } \\
\text { Organizations }\end{array}$ & $\begin{array}{c}\text { Percentage (of All } \\
\text { Organizations) }\end{array}$ \\
\hline Christian-Muslim & 173 & $37.4 \%$ \\
Christian-Jewish & 100 & $21.6 \%$ \\
Jewish-Muslim & 100 & $21.6 \%$ \\
Intra-Christian & 47 & $10.2 \%$ \\
Intra-Muslim & 11 & $2.4 \%$ \\
Shia-Sunni & 8 & $1.7 \%$
\end{tabular}

${ }^{1}$ Organizations covered by the KAICIID Peace Map also focus on interreligious dialogue with other religions, including Animist, Buddhist, Druze, Hindu, or Sikh communities. Still, none of these religions are explicitly targeted by more than nine organizations. Finally, 206 (of a total of 463 organizations contained in the dataset) promote interreligious dialogue on a more general scale, without focusing on the relations between specific religious communities.

With regards to the eight organizations that have addressed Shia-Sunni relations, the degree to which these organizations focus on Shia-Sunni relations varies considerably. For instance, whereas the Royal Aal al-Bayt Institute for Islamic Thought, based in Jordan, defines its main goal as advancing dialogue between the seven Islamic schools of jurisprudence, the UNESCO Association for Interreligious Dialogue, and the International Council for Inter-Religious Cooperation adopt a much broader focus, although they have previously organized events and seminars addressing Shia-Sunni relations. The US-based Salam Institute for Peace and Justice primarily promotes dialogue between Muslim and non-Muslim communities, but has, for instance, also organized meetings with religious authorities in Iran to discuss Shia-Sunni relations. Another organization that partially addresses Shia-Sunni relations is the Malaysia-based International Institute of Advanced Islamic Studies. The Association for Conflict Transformation (ACT) of the Cordoba Foundation of Geneva (CFG) is particularly active in different parts of the Muslim world and has thus also worked in contexts where it sought to foster dialogue in violent conflicts with a Shia-Sunni dimension. The Organization of Islamic Cooperation (OIC), despite promoting dialogue between the different Islamic sects, suffers from several problems, which are discussed to a greater extent in relation to our third hypothesis (Section 3.3). Finally, since the outbreak of the Syrian Civil War, the MENA Council of Religions for Peace (RFP), an international organization created in 1970, has sought to advance dialogue between religious authorities, including Sunni and Shia representatives. It is noteworthy that, apart from the Organization of Islamic Cooperation (OIC), none of the eight organizations that are listed in the KAICIID dataset has offices in a country that has both sizeable Shia and Sunni populations.

While we recognize limitations with regards to the comprehensiveness of the KAICIID Peace Map, as it may fail to include all such organizations, we see no reason to expect that this would introduce a systematic bias against the information gathered about Shia-Sunni dialogue. We therefore consider the fact that only 1.7 percent of the listed organizations focus specifically on Shia-Sunni relations to be indicative of a general interreligious peacemaking deficit when it comes to addressing Shia-Sunni tensions and violence. We have also consulted two other sources on interreligious peacemaking and dialogue, and both reveal a similar empirical picture. One such source is provided by the Directory of InterFaith and InterReligious Organizations (Guerrand-Hermès Foundation for Peace 2018). It lists a total of 42 additional organizations not covered by the KAICIID list, none of which seems to explicitly address the Shia-Sunni divide. Moreover, in their 2005 report, Bouta et al. (2005) report on a large number of Christian and Muslim faith-based peacebuilding organizations. While providing strong evidence that besides Christian organizations, there is also a substantial number of Muslim peacebuilding organizations (particularly in Africa), only a small share of these organizations specifically focuses on interreligious peacemaking and dialogue, and none seem to specifically address Shia-Sunni relations.

Since the US invasion of Iraq in 2003, there has been an increasing prevalence of organized violence and armed conflicts along the Shia-Sunni fault line, which has further escalated over the past 
decade (Finnbogason et al. 2019). However, this does not seem to have prompted the creation of new organizations and institutional attempts focusing on Shia-Sunni relations. In fact, only two of the eight organizations mentioned here were founded after 2003-in 2008 and 2009, respectively.

Taken together, the two empirical trajectories that we have identified above present us with a puzzle. In 2017, 44 percent all the world's fatalities in organized violence resulted from conflicts with Shia-Sunni dimensions (Finnbogason et al. 2019). Still, very few institutional mechanisms and organizations have been set up to explicitly address this fault line. This deficit of peacemaking and dialogue has neither been noted nor discussed in previous research, regardless of whether that research focusses on Shia-Sunni sectarianism (or sectarianization) (e.g., Byman 2014; Haddad 2017; Hasheemi and Postel 2017) or rather on interreligious dialogue and religious peacemaking (e.g., Cheetham et al. 2013; Haynes 2007; Smock 2002). In this study, we seek to explore why so few interreligious peacemaking initiatives seem to be targeted at conflicts between Shias and Sunnis, when the need for such dialogue is evident.

\section{Potential Explanations}

\subsection{Hypothesis One: There Is a Lack of Shia-Sunni Interreligious Peacemaking Because There Is No Need for It}

A potential explanation of the Shia-Sunni dialogue deficit is that the Shia-Sunni divide is simply epiphenomenal. Behind rhetoric and positioning, there is, from this perspective, no fundamental animosity between the two Muslim communities. Therefore, the lack of dialogue across the Shia-Sunni divide simply reflects that such a dialogue has never been needed. From this perspective, focusing on the Shia-Sunni dimension risks enforcing group stereotypes and misleading any efforts for building security and peace. Dialogue or peacemaking initiatives between Shias and Sunnis are therefore fundamentally unnecessary, and that is why we see so little of it.

While we acknowledge that this hypothesis may carry some explanatory weight, it needs to be qualified. Over long time periods and in many different regions of the wider Middle Eastern world, Shias and Sunnis have lived peacefully with each other, intermarriages have not been uncommon, and the social cohesion and collaboration between the communities have been strong and robust. Periods of hostilities have been followed by periods of peaceful coexistence, when the Shia-Sunni divide has been superposed by other, more pressing urgencies. Also, as pointed out at the start of this article, there is close to a scholarly consensus that ethnic and religious identities in general, including the Shia-Sunni identity divide, cannot by themselves explain conflict and lack of peacemaking, thus providing little support for the "ancient hatred" theory (a point made, for instance, by (Salloukh 2017; Sayigh 2017). Instead, conflicts with Shia-Sunni dimensions are, in most cases, the result of identity politics, where authoritarian leaders cynically exploit sectarian differences for their own political aims (Lynch 2013).

Still, even if Shia-Sunni polarization may not be the root cause of conflicts in the Middle East and other parts of the wider Muslim world, it has certainly been a consequence. The levels of violence between actors that mobilized at least partly along Shia and Sunni identity cleavages in Syria, Iraq, Yemen, Afghanistan, and Pakistan have contributed to increased sectarian tensions between Shia and Sunni communities. Surveys following the Arab Spring (conducted between November 2011 and May 2012) found that a substantial proportion of people in the Middle East themselves were aware of problems related to sectarian tensions. For example, in Lebanon, two-thirds of Muslims perceived sectarian tensions as a big or moderately big problem. This share lay at approximately 50 percent among Iraqi Muslims, more than 40 percent in Afghanistan, and close to 25 percent in Iran (Pew Forum 2013).

Surveys have also found a substantial part of Sunnis to not recognize Shias as fellow Muslims. The most comprehensive study of this was published by the Pew Forum in 2012 ("The World's Muslims: Unity and Diversity"). It involved 38,000 face-to-face interviews in 39 countries with Muslim populations, finding strong evidence for sectarian tensions, although with significant geographical variations. Muslims in the Middle East and North Africa (MENA) region appeared to be most aware of the distinction between Sunni and Shia. In most surveyed countries (five out of seven) in this region, at least 40 percent of Sunnis reported to not accept Shias as fellow Muslims, and in many cases, 
an even greater percentage reported that some Shia practices, such as visiting sacred shrines, were unacceptable as parts of an Islamic tradition. In Egypt and Morocco, the dominant view was of Shias not being Muslims, while opinion was closely divided on the issue in Tunisia, Jordan, and Palestine. Whereas Shias were not viewed as Muslims to a substantial extent in several Sunni majority countries, Sunnis were rarely considered as not being Muslims in any of the surveyed countries. Only in Iraq and Lebanon-both countries with sizeable Shia populations-did large majorities of Sunnis accept Shias as fellow Muslims, as well as their distinctive practices. These findings can be interpreted as indications that if Sunnis and Shias live together, mutual recognition as Muslims is more likely. On the other hand, outside of the MENA region, the distinction between Shias and Sunnis seemed much less relevant for Muslims. In many Central Asian countries, most Muslims did not even self-identify as Sunni, but rather reported to be "just a Muslim." Similar patterns were observed for Southern and Eastern Europe, as well as Indonesia (Pew Forum 2012).

Due to constraints on data availability, it is not possible to provide a comprehensive answer as to whether sectarian tensions have increased over time. However, it is possible to get a snapshot at this question. ${ }^{2}$ In its Wave IV survey (2016-2017), the Arab Barometer asked respondents about their feelings toward certain groups, including Shias and Sunnis (question 834). This survey was conducted in Algeria, Egypt, Jordan, Lebanon, Morocco, Palestine, and Tunisia. Thus, unfortunately, no data are available from the two countries with the highest levels of violence with Shia-Sunni dimensions, Syria and Iraq. Still, some important findings can be drawn. The responses indicate that Sunni Muslims in Northern African countries, as well as in Palestine, tend to hold negative feelings toward Shia Muslims. In the four surveyed Northern African countries, the number of self-identifying Sunni respondents per country ranges from 908 in Tunisia to 1146 in Egypt, 1189 in Morocco, and 3300 in Algeria. ${ }^{3}$ At least 62 percent of the (Sunni) Muslim respondents in each country reported to be at least "somewhat angry" towards Shia Muslims. Moreover, the percentages of people reporting to feel "very angry" is also substantial. In all these five countries, the number of respondents feeling "very angry" toward Shia Muslims was larger than the number of those reporting to feel "somewhat angry." In Egypt, this share was the highest, with 58 percent of the respondents feeling "very angry" toward Shia Muslims. In Lebanon, the country with the highest share of Shia Muslims in the population, there seems to be much less antagonism, both from Sunnis toward Shias and vice versa, which could lend support to arguments based on intergroup contact theory (Arab Barometer 2018). The Pew Forum and Arab Barometer surveys are the most reliable data sources available that provide information on attitudes between Shia and Sunni Muslims on a cross-country level. In this study, we do not primarily seek to explain these attitudes but instead wish to make use of them to illustrate that decades of sectarian violence and instrumentalization by authoritarian politicians seem to also have contributed to skeptical, if not hostile, attitudes among members of these sects, at least in some countries.

Thus, even if the Shia-Sunni divide may not be a root cause of contemporary organized violence and armed conflicts in the Middle East and other parts of the wider Muslim world, the sectarian dimension has been activated throughout different countries and regions. In fact, it has grown to become the master cleavage in today's Middle Eastern politics, and it also plays an important role in other parts of the wider Muslim world, including countries such as Afghanistan (Seerat 2017), India (Sharma 2016), Nigeria (Sunday 2019), or Pakistan (Rathore 2017). We conclude from this that there is a real need for institutional responses in form of interreligious dialogue and peacemaking across the Shia-Sunni divide.

2 Polls with comparable questions have not been asked systematically over time. For example, in versions prior to Wave IV, the Arab Barometer did not ask specifically about respondents' attitudes toward Shia or Sunni Muslims. The Wave IV survey is the first study where this was addressed.

3 In the case of Egypt, the survey only contains the answer options of "Muslim" or "Christian." 
3.2. Hypothesis Two: There Is a Lack of Shia-Sunni Interreligious Peacemaking Because Interreligious Dialogue Is a "Western" Phenomenon

Previous research has described the history of the concept of interreligious dialogue and the interfaith movement (Braybrooke 1998; Forward 2001; Halafoff 2013; Marshall 2013; Swidler 2013). Its origins are predominantly Christian and rooted in Western societies: the changing focus in Christianity from proselytization toward a greater emphasis on interreligious dialogue that occurred in the second half of the 20th century is highlighted by different authors as a key driver for the growth of interreligious dialogue (Cheetham et al. 2013; Moyaert 2013). A potential explanation for the lack of Shia-Sunni dialogue is therefore that interreligious dialogue is alien to the Muslim traditions, cultures, and contexts.

The first glance at the empirical record yields a mixed picture. On the one hand, the KAICIID dataset provides information on the religious affiliation of 202 international organizations engaged in interreligious dialogue and peacemaking. ${ }^{4}$ Whereas 133 organizations are linked to a branch of Christianity, only 29 organizations are reported as having a Muslim affiliation, 28 to Judaism, 12 to Buddhism, and six to Hinduism. Eight organizations are listed as secular. These numbers support the notion of interreligious dialogue being a phenomenon predominantly rooted in non-Muslim societies. In line with this finding, Bouta et al. (2005) argue that it is difficult to identify Muslim peacebuilding organizations, which they assume to be explained by a lack of institutionalization: peacebuilding is mostly done by individual actors, such as imams or sheikhs, and often in a rather informal manner. Still, the authors note that "one should not conclude from this that there are hardly any Muslim-based peace-building activities" (Bouta et al. 2005, p. x). Their study further identifies and discusses 14 Muslim faith-based peacebuilding organizations, most of which are not covered by the KAICIID Peace Map, which further underlines that these organizations do exist, although they might be less common than their Christian counterparts. Thus, institutional interreligious dialogue and peacemaking are not alien to the Muslim context.

Moreover, there is an important historical trajectory of "ecumenical" efforts within Islam. Even though it is easy to portray the relationship between Sunni and Shia Muslims as a history of conflicts and tensions, it is also necessary to pay attention to individual and organizational efforts to promote understanding and rapprochement. Indeed, some theologians have worked hard to promote understanding, cohesion and brotherhood among all Muslims, despite the many differences when it comes to dogmata or rituals. Instead of addressing or paying close attention to historical discords (e.g., who should be the proper leader of Muslims after the death of the Prophet Muhammad) and disputes over how to understand and apply Islam, these theologians have stressed that all Muslims should be bound together by the fact that they are Muslims.

As pointed out by Ende (2018a, 2018b) and Brunner (2004, 2011), it was primarily the development of the pan-Islamism ideology (e.g., in organizations like the Muslim Brotherhood) and the rise of Gamal Abdel Nasser (1918-1970) to power in Egypt in 1952 that provided a window of opportunity for theologians that wanted to promote a theological program that stressed that all Muslims should be seen as equal. This was, however, not an initiative that aimed to neglect existing differences, but to put focus on unity rather than conflicts and splits. Moreover, already prior to this, during the 18th century in India, ecumenical attempts had been made by the Muslim ruler Nadir Shah. Since then, several individual Muslim thinkers have tried to promote similar ideas in other places. Yet, these initiatives primarily depended on isolated individuals or the mercy of local rulers that saw rapprochement as a pragmatic tool that could be used for political purposes. When the Al-Azhar University in Cairo started the society Jamaat al-takrib bayn al-madhahib al-Islamiyya ("Association for the rapprochement of the Islamic Schools of law") in 1947, the situation changed. From this point in time, there was a society

4 No information is available on the religious affiliation of the remaining 261 organizations. This is mostly because these are international organizations not rooted in any of the world's major religions. 
that included both Sunni and Shia Muslims with a common ambition to work toward reconciliation between the different branches of Islam. Among its supporters and followers, we find the rector of the Al-Azhar, Mahmud Shaltut (d. 1963), who issued a fatwa in 1959 that declared the Twelver Shias to be valid and that the legal school of this tradition (i.e., the so-called Jafarite school) should be recognized.

Even though the initiatives above were important—not least among the political and religious establishment - they never became fully accepted or popular among the common population. The ideas of the so-called dar al-taqrib were therefore supported only where they could be exploited by the political establishment for promoting anticolonial sentiments and fostering unity among the Muslims in the Middle East. Moreover, the ambition to unite all Muslims was already threatened from the start by the rise of the new nation states of the Middle East (i.e., after the end of colonialism), the cold war and the rise of Wahhabism in Saudi Arabia that saw Shia Islam as a danger to "pure" Islam (Polka 2013, p. 422). With the Iranian revolution in 1979 and the declaration of the theocratic state of Iran-based on Twelver Shiism - the institutional attempt to promote unity and reconciliation between Sunni and Shia Muslims experienced a serious setback. The revolution sparked a general fear among Sunni Muslims and many Arab leaders feared that Shia Islam and the revolution could be exported to other countries of the Middle East. Since the 1960s and the weakening of the dar al-taqrib in Cairo, there have been some Iranian attempts to establish equivalent organizations, which remained unsuccessful outside a very small Shia Muslim minority.

Those who argue that rapprochement is the way forward have often stressed that it is the enemies of Islam that gain from the division and split that exists among Sunni and Shia Muslims. In the 1940s, the external enemy was colonial power, whereas today, the enemy is often seen in the state of Israel. For instance, Yusuf al-Qaradawi, a prominent Egyptian Islamic theologian (b. 1926), has argued that the Sunni animosity against Hezbollah should be put aside as long as Israel provides a common enemy. In 2003, by employing a similar line of reasoning, he tried to stop the blood bath between Sunni and Shia Muslims in Iraq, which had been unleashed by the US-invasion of the country: in this case, it was the external enemies - i.e., the invading troops of the United States, Al-Qaeda, etc.- that exploited the internal conflicts for their own interests. From this point of view, it is easy to employ the same argument when it comes to the conflicts that followed the uprisings in Syria. The Syrian Civil War, too, is a conflict with external enemies, in which key actors exploit divisions and old tensions within the population of the country. Theologians who call for rapprochement, unity, and a focus on theological and political questions are aware of the split and unwanted discord that is caused by those who work to enforce sectarian divisions. Today, however, there are few theologians or organizations that employ Islamic ecumenism to reach rapprochement between Sunni and Shia Muslims as a higher goal. Still, as the historical overview above has demonstrated, it is not alien to Muslim theological development or core faith institutions. The deficit of institutional intra-Muslim dialogue along the Shia-Sunni cleavage can therefore not be explained by depicting interreligious dialogue as a purely "Western" phenomenon.

\subsection{Hypothesis Three: There Is a Lack of Shia-Sunni Interreligious Peacemaking Because Peacemaking Occurs through Other Channels}

We started this analysis by showing that only less than two percent (1.7 percent) of the world's interreligious peacemaking organizations have had an explicit Shia-Sunni focus, according to the KAICIID Peace Map. One explanation for this may be that such dialogue occurs through inter-governmental international organizations, such as the United Nations (UN), or internal, informal, processes within states affected by Shia-Sunni conflict. ${ }^{5}$ This hypothesis is also plausible if we consult earlier research on Sunni and Shia Muslim relations (e.g., (Brunner 2004). According to this research, there is a lack of organizations that would have the capacity or trust to engage in a serious dialogue in

5 The KAICIID Peace Map also includes smaller, specialized UN agencies, for example the UNESCO Chair in Interreligious and Intercultural Relations or the UNESCO Chair in Intercultural and Interreligious Dialogue for South-East Europe. 
conflicts between Sunni and Shia Muslim actors or communities. Attempts are often made by individual Muslim theologians or by one side in a conflict, but there is a lack of well-organized ecumenical organizations that hold the trust and capacity to engage in peacebuilding, dialogue, or negotiations.

Indeed, there has been an extensive engagement of the UN, not least through mediation and involvement in Shia-Sunni conflicts in Syria, Yemen, Lebanon, or Afghanistan. However, the high degree of UN engagement also reflects a lack of regional capacities to manage these violent conflicts. Thus, there have been few internal institutional responses from the countries and societies themselves. Instead, "because of the low level of institutionalization across the sectarian divide in the region (i.e., across the Saudi-Iranian divide) the UN is by default called on to monitor and mediate peace agreements" (Sisk 2017, p. 272).

It is further important to recognize the failure of the major regional organizations, the OIC, GCC, and Arab League, to bridge the Shia-Sunni divide. With 57 member states, the Organization of Islamic Cooperation (OIC) — until 2011 known as "Organization of Islamic Conference" —is the world's second largest international organization, after the UN, formally representing more than 1.5 billion Muslims around the world. In 2006, OIC Secretary General Ekmeleddin Ihsanoglu reached out to Sunni and Shia leaders in Iraq and invited both sides to a reconciliation meeting that resulted in the signing of the Mecca Declaration on 20 October 2006. The OIC's involvement was received largely positive by the international community and contributed to alleviate Shia-Sunni tensions in many parts of the country. The OIC has also been involved in the process leading to the Djibouti Agreement in the Somali conflict in 2008 and supported dialogue processes between the government of Thailand and the Muslim minority and between the government of the Philippines and the MNLF rebels. More recently, however, criticism against the organization has been on the rise, specifically due to its internal divide. First, the double and triple membership of many member states in organizations that perform similar work, such as the African Union or the Arab League, bears the risk of duplicating mediation efforts by different actors and institutions. Second, the OIC Secretary General's authority to initiate mediation in conflicts depends on the political will from member states (Sharqieh 2012, pp. 230-31). Related to this is a third challenge that concerns rivaling strategic interests among OIC member states, especially regarding Saudi Arabia and Iran. The relationship between the two states evolved from a regional rivalry into increased hostility after the fall of the Pahlavi dynasty in Iran in 1979 and the subsequent war between Iran and Iraq, which saw significant support for Saddam Hussein's Iraqi government from Saudi Arabia and other Gulf states (Keynoush 2016). Eventually, the First Gulf War (1990-1991) marked the beginning of an increased US engagement in the region, which, due to the US alliance with Saudi Arabia, contributed to renewed resistance and countering strategies by Iran (Mason 2014, p. 24). Already nearly two decades ago, Haynes (2001, p. 154) identified these states as "the chief rivals for superiority in the OIC ( ... )" who "used some of their oil wealth to try aggressively to expand international influence," a situation that has hardly improved since. More recently, it was in the aftermath of the Arab uprisings in 2011 that the rivalry between Iran and Saudi Arabia escalated and became increasingly influential for the political dynamics in the region (Mabon 2015). Thus, if their interests diverge on a specific conflict, Iran and Saudi Arabia tend to prioritize their own strategic interests over those of the OIC. Moreover, they also influence the behavior of allied states, thereby complicating any mediation effort even further. Given the conflicting interests of some of its key member states, the OIC's capacity to play a mediating role in Shia-Sunni conflicts is further hindered by its organizational set-up that requires consensus among member states for major decisions to be taken (Sharqieh 2012, pp. 230-31).

Another major organization that could potentially act as a peacemaker in violent conflicts across the Shia-Sunni fault line is the Gulf Cooperation Council (GCC). Established in 1981, the alliance has six member states: Bahrain, Kuwait, Oman, Qatar, Saudi Arabia, and the United Arab Emirates. It promotes cooperation on economic, security, cultural, and social affairs. Similar to the OIC, since the beginning of the Arab Spring in 2011, the GCC has experienced a process of internal fragmentation that has been largely attributed to differing security interests of its members (Al Jazeera 2017; Lenderking et al. 2017). 
By summer 2017, a split between GCC members Bahrain, Saudi Arabia, and the United Arab Emirates (plus non-GCC member Egypt) on the one side, and Qatar on the other side, became evident. Qatar was accused of colluding with Iran and Iran-backed militias, as well as funding terrorist organizations in the region. This crisis reflected a deep fragmentation within the GCC and also in the wider Middle East. Kuwait and Oman refused to align with the anti-Qatar bloc, with the Emir of Kuwait offering mediation among the parties. The ethnically diverse composition of Kuwait (30 percent Shia citizens) made the government particularly weary of the risks of sectarian conflict in the region (Bianco and Stansfield 2018, pp. 614-17). Kuwait's mediation efforts, however, remained unsuccessful, to a large extent due to the refusal of the Saudi-led bloc to participate in the talks (Bakeer 2017). The distinctive socioeconomic and sociopolitical traits of the GCC members, despite sharing strong historical and cultural bonds, are currently diverging rather than converging. As long as this development of internal fractionalization of the GCC persists, it appears unlikely that the organization will be able to act as a unitary actor in a mediating function (Bianco and Stansfield 2018, p. 634).

A third major regional international organization is the Arab League, which for a long time was known for its principle of noninterference in international conflict. Between 1945 and 2008, it had only mediated in five of 22 civil wars in the Middle East. However, with the beginning of the Arab Spring, the organization seemed to be taking a more active stance, as it supported a no-fly zone over Libya and suspended the country's membership, as well as that of Syria later during that same year. Yet, like the GCC, the Arab League has suffered from the increased regional polarization that has unfolded since the Arab Spring. Supporters of the uprisings, such as Tunisia, have had contrasting interests to defenders of the status quo, such as Saudi Arabia and Egypt. Another source of conflict has been the Muslim Brotherhood, sponsored by Qatar but labelled as a terrorist organization by Saudi Arabia and Egypt. The member states' relations with the Iranian regime are complicating things further, since the Arab League is comprised of both Iranian allies, such as Lebanon and Iraq, and adversaries, most importantly Saudi Arabia. The organization also lacks a charter that would enable it to take binding and enforceable resolutions in relation to its member states, but the political will of its member states to take the necessary reforms is currently missing (Bröning 2014; Worrall 2017).

The UN-dominated peacemaking has led to a situation where interreligious dialogue has not been at the center of attention. Indeed, a common critique against traditional diplomatic approaches is precisely that such engagement tends to avoid a deeper engagement with religiously anchored dimensions of conflicts. It has been suggested that Western governments often lack openness and sophistication in their interactions with religious institutions in countries experiencing religious conflict (Smock 2006, p. 1). A similar criticism is voiced by Marshall, who criticizes that religion has remained largely absent from the core disciplines of international relations, in both academic and practitioner-focused debates, as well as in large parts of civil society. In this context, Marshall identifies "a broad religious 'illiteracy' within policy communities," including a lack of professional frameworks to address religious questions (Marshall 2013, p. 2).

However, there have been traditional, less institutionally developed approaches to interreligious peacemaking that have been utilized to address the Shia-Sunni violence in the region. For example, it has been shown that tribal law and traditional conflict resolution mechanisms have been widely utilized in Iraq following the sectarian violence and have helped to bring about reconciliation between communities (Carroll 2011). It is plausible that the deficit in institutional interreligious Shia-Sunni peacemaking reflects the occurrence of such peacemaking practices through less formal channels, including traditional and tribal mechanisms, in line with what was argued by Bouta et al. (2005). The extent to which this is the case remains to be explored, but it could potentially be an explanation for why we see so little institutional Shia-Sunni religious dialogue. Recent research shows that top-down appeals can be conducive for cross-sectarian cooperation across the Shia-Sunni identity cleavage (Chang and Peisakhin 2019). 


\section{Avenues for Future Research}

This study has tried to identify and establish the puzzling empirical phenomenon of the Shia-Sunni interreligious dialogue deficit. This may encourage future research to devote greater attention to the lack of institutional Shia-Sunni dialogue initiatives, which is surprising against the backdrop of the escalation of organized violence that has occurred along the intra-Muslim sectarian divide. Organized violence between Shia and Sunni Muslims represents one of our most pressing security challenges: over the last few years, almost half of all fatalities in organized violence in the world occurred along the Shia-Sunni rift. In this context, special attention should be paid to state-based armed conflicts, that is, conflicts that involve at least one government of a state as a conflict party. Between 1989 and 2017, approximately 90 percent of all fatalities in conflicts with Shia-Sunni dimensions occurred in conflicts that involved state-level actors (Finnbogason et al. 2019, p. 43). Research needs to understand why there are so few institutional attempts to bridge this divide.

Of the three explanations we have discussed in this study, the third one appears most promising for future research to pursue. In particular, what is needed are studies that help clarify how institutional attempts, primarily by the UN as well as informal attempts at the lower societal levels, can bridge the Shia-Sunni divide. In this context, we wish to highlight that the second and third hypothesis in this study are not mutually exclusive: we have illustrated local, less institutionalized instances of Shia-Sunni dialogue that have occurred, for example the initiative by al-Qaradawi in Iraq after the escalation of sectarian violence in 2003. Such cases of Shia-Sunni dialogue do in fact indicate, with respect to our second hypothesis, that interreligious dialogue is not necessarily a Western phenomenon, and with regards to our third hypothesis, that it may occur through other channels. Still, more research is needed to systematically assess to what extent such local initiatives are taking place in non-Western countries affected by Shia-Sunni violence. Future research should also examine the conditions under which interreligious dialogue is successful in creating processes of de-sectarianization and how religious actors, leaders, communities, and organizational resources can be incentivized to create effective channels for dialogue and for the reduction of tensions.

The variations in group relationships need to be explained, not by extrapolating medieval-based historical animosities, but through modern political processes that involve the political elites. There are good reasons to believe that theological differences have been used for promoting discord between groups and individuals in both past and present (e.g., (Bengio and Litvak 2011; Maréchal and Zemni 2013). In some cases, the rhetoric use of a religious vocabulary has been employed for harassing and whipping up aggression against the religious "other." The latest wars in Syria and Iraq, but also the Iranian revolution in 1979 and the following Iran-Iraq wars, are illustrative cases. Political elites with authoritarian agendas and aspirations, in countries such as Saudi Arabia, Iran, Iraq, Lebanon, and Syria, have had self-interests to construct and maintain antagonistic sectarian identities and have acted in ways to fane sectarian violence. Moreover, Western governments fueled these dynamics by providing strategical support for sectarian regimes, on the one hand, and by military interventions that dramatically increased sectarian violence, such as the 2003 United States-led invasion in Iraq, on the other hand. Countries with significant Shia or Sunni minorities in which sectarian identities have been politicized suffer from unfulfilled state-building processes and a lack of social cohesion. Together with the Iran-Saudi Arabia rivalry, this has contributed decisively to sectarian violence as well as to a lack of dialogue.

We have shown in this study that while the rise in organized violence with Shia-Sunni dimensions can be explained by certain specific developments-in particular, the critical junctures of the United States-led invasion of Iraq in 2003 and the Arab Spring in 2011-the lack of dialogue is driven by other processes. The 2003 invasion of Iraq and subsequent turmoil in the country provided fertile soil for the growth of IS and its conflict with the government of Nouri al-Maliki. IS was able to draw on the resentment in Sunni communities toward the increasingly sectarian policies of al-Maliki's government, which favored Iraq's Shia majority population. The Arab Spring in 2011, on the other hand, provided 
the backdrop for the civil war in Syria that would come to have repercussions for the entire region, not the least by providing IS with an opportunity to spring back to life and reignite sectarian violence.

Clearly, in some of the contexts experiencing violence with Shia-Sunni dimensions, the space for interreligious dialogue and peacemaking is extremely small, especially where conflicts involve Al-Qaeda- or IS-linked groups. In some conflicts, the targeting of the community of the religious "other" is part of the rationale for the conflict. For example, radical Sunni groups target Shias due to (at least partly) theological reasons. For successful interreligious peacemaking to take place, the involved actors must acknowledge that there is room for growth in their understanding of the truth, as well as to acknowledge that their religion is somewhat interconnected with the religious "other." Moreover, "hospitality" is required, which means that actors recognize actual truth, at least to some extent, in another religion, and that they view it as possible to include this into their own religion (Cornille 2013, p. 28).

We leave it to future research to examine the conditions under which interreligious peacemaking and dialogue can be effective. Previous research shows that faith-based mediation and religious peacemaking are most frequently utilized when the conflict issues are not defined in religious terms and when the religious identity can serve as a bridge between the antagonist parties (Johnstone and Svensson 2013). Moreover, previous research points toward the importance of religious communities: they represent key actors in religious conflicts, whose networks should be used by peacemakers to foster dialogue (Smock 2006). They can also play an important role due to their moral authority, which allows them to gain the trust of people who may live under corrupt and repressive regimes, as well as their direct access to the population, due to their long-term involvement in grassroots work in conflict settings (Halafoff 2013, p. 268). On the other hand, if international peacemakers decide to collaborate with certain religious organizations or actors, in the absence of functioning state institutions, there is a risk of reinforcing existing feelings among the population of clientelism and ethnic or faith-based service delivery. In other words, by focusing too narrowly on religious identity in peacebuilding, those identities may be inadvertently further inscribed, thereby exacerbating tensions (Cox et al. 2014, p. 2). Interreligious peacemaking may be more likely to be successful, where it is linked to secular and political processes and authorities (Smock 2006, p. 36).

The deficit of Shia-Sunni interreligious dialogue can be partly understood as a function of an undersupply of vibrant and free civil society organizations, and potentially a reflection of a wider democracy deficit in the Middle East and other parts of the wider Muslim world. The latter has been the subject of a long, still ongoing academic debate about Middle Eastern or Muslim exceptionalism, after several authors characterized political developments in these countries as exceptional, unusual, or unique (Bellin 2004; Borooah and Paldam 2007; Stepan and Robertson 2003). Some authors linked these developments to Islam itself (Huntington 1996; Lakoff 2004; Rowley and Smith 2009). Especially after the Arab Spring, but also earlier (Sørli et al. 2005), this notion of Muslim exceptionalism has evoked increasing criticism by authors who have instead highlighted the importance of political and colonial history (Hariri 2015), ethnolinguistic factors (Mabry 2015), or gender (el-Husseini 2016) to understand what is often perceived as a democratic deficit in the Middle East and the Muslim World. Others have pointed out how actors in Muslim democracies in fact often use Islamic concepts to contribute to democratization (Kubicek 2015). The existence of a civil society that transcends religious or ethnic cleavages is an important explanation for the capacity of societies to maintain civil peace, particularly in light of external provocations and turmoil (Varshney 2002). Organizations that can clarify misunderstandings and kill rumors help to work against negative stereotypes and prejudices, threat perceptions, and hostile attitudes. Resilience and social cohesion are lacking in the Middle East due to a colonial past and unfinished state-formation processes, weak state institutions, or lack of independence of, and space for, the civil society. To sufficiently address this issue lies beyond the scope of this article. Still, it would be worthwhile to examine whether the Shia-Sunni communities in the diaspora, some of which are living in societies with stronger institutional frameworks allowing for more civil agency, may in fact be more engaged in such dialogue. In a more general sense, future 
research can help to shed light upon factors that explain the occurrence (or absence of) interreligious dialogue in conflicts with Shia-Sunni dimensions.

Author Contributions: Conceptualization, I.S., G.L.; methodology, I.S.; formal analysis, D.K.; investigation, D.K., I.S., G.L.; data curation, D.K.; writing—original draft preparation, D.K., I.S., and G.L.; historical and theological research, G.L.; writing—review and editing, D.K., I.S., and G.L.; visualization, D.K.; supervision, I.S.; project administration, I.S.; funding acquisition, I.S.

Funding: This research was funded by STIFTELSEN RIKSBANKENS JUBILEUMSFOND, grant number NHS14-1701:1.

Acknowledgments: We thank Daniel Finnbogason for great collaboration on the data-collection. We also appreciate comments on earlier drafts from Julia Palmiano Federer, Jason Klocek, Mimmi Söderberg-Kovacs, Mark Juergensmeyer, and Desirée Nilsson.

Conflicts of Interest: The authors declare no conflict of interest. The funders had no role in the design of the study; in the collection, analyses, or interpretation of data; in the writing of the manuscript, or in the decision to publish the results.

\section{References}

Abdo, Geneive. 2017. The New Sectarianism: The Arab Uprisings and the Rebirth of the Shi'a-Sunni Divide. New York: Oxford University Press.

Ahmed, Khal. 2011. Sectarian War: Pakistan's Sunni-Shia Violence and its Links to the Middle East. New York: Oxford University Press.

Al Jazeera. 2017. What Is the GCC? Available online: https://www.aljazeera.com/news/2017/12/gcc171204094537378.html (accessed on 18 September 2018).

Anderson, Benedict. 2006. Imagined Communities: Reflections on the Origin and Spread of Nationalism. Brooklyn: Verso Books.

Arab Barometer. 2018. Arab Barometer Wave IV (2016-2017): Codebook. Princeton: Arab Barometer.

Bakeer, Ali. 2017. GCC crisis: Why is Kuwaiti mediation not working? Al Jazeera, August 11.

Behuria, Ashok K. 2004. Sunni-Shia relations in Pakistan: The widening divide. Strategic Analysis 28: 157-76. [CrossRef]

Bellin, Eva. 2004. The Robustness of Authoritarianism in the Middle East: Exceptionalism in Comparative Perspective. Comparative Politics 36: 139-57. [CrossRef]

Bengio, Ofra, and Meir Litvak. 2011. The Sunna and Shia in History_Division and Ecumenism in the Muslim Middle Eas. Basingstoke: Palgrave Macmillan.

Bianco, Cinzia, and Gareth Stansfield. 2018. The intra-GCC crises: Mapping GCC fragmentation after 2011. International Affairs 94: 613-35. [CrossRef]

Borooah, Vani K., and Martin Paldam. 2007. Why is the world short of democracy? A cross-country analysis of barriers to representative government. European Journal of Political Economy 23: 582-604. [CrossRef]

Bouta, Tsjeard, S. Ayse Kadayifci-Orellana, and Mohamed Abu-Nimer. 2005. Faith-Based Peace-Building: Mapping and Analysis of Christian, Muslim and Multi-Faith Actors. Washington: Institute for Peace and Justice.

Braybrooke, Marcus. 1998. Faith and Interfaith in a Global Age. Grand Rapids: CoNexus Press.

Bröning, Michael. 2014. The End of the Arab League? What the Organization Can Learn from the African Union. Available online: https://www.foreignaffairs.com/articles/persian-gulf/2014-03-30/end-arab-league (accessed on 20 November 2018).

Brunner, Rainer. 2004. Islamic Ecumenism in the 20th Century: the Azhar and Shiism between Rapprochement and Restraint. Leiden: Brill, vol. 91.

Brunner, Rainer. 2011. Interesting Times: Egypt and Shi'ism at the Beginning of the Twenty-First Century. In Sunna and Shia in History-Division and Ecumenism in the Muslim Middle Eas. Edited by Ofra Bengio and Meir Litvak. Basingstoke: Palgrave Macmillan, pp. 223-41.

Byman, Daniel. 2014. Sectarianism Afflicts the New Middle East. Survival 56: 79-100. [CrossRef]

Carroll, Katherine Blue. 2011. Tribal Law and Reconciliation in the New Iraq. The Middle East Journal 65: 11-29. [CrossRef]

Chang, Han, and Leonid Peisakhin. 2019. Building Cooperation Among Groups in Conflict: An Experiment on Intersectarian Cooperation in Lebanon. American Journal of Political Science 63: 146-62. [CrossRef] 
Cheetham, David, Douglas Pratt, and David Thomas. 2013. Understanding Interreligious Relations, 1st ed. Oxford University Press: Oxford.

Cornille, Catherine, and Stephanie Corigliano. 2012. Interreligious Dialogue and Cultural Change. Eugene: Cascade Books, vol. 4.

Cornille, Catherine. 2013. The Wiley-Blackwell Companion to Inter-Religious Dialogue. Chichester and Malden: Wiley Blackwell.

Cox, Fletcher D., Catherine R. Orsborn, and Timothy D. Sisk. 2014. Religion, Peacebuilding, and Social Cohesion in Conflict-Affected Countries. Denver: University of Denver.

Cox, Fletcher D., Timothy D. Sisk, and Elizabeth Hester. 2017. Introduction. In Peacebuilding in Deeply Divided Societies, Toward Social Cohesion? Edited by Fletcher D. Cox and Timothy D. Sisk. Cham: Palgrave Macmillan.

Eck, Kristine, and Lisa Hultman. 2007. One-Sided Violence Against Civilians in War: Insights from New Fatality Data. Journal of Peace Research 44: 233-46. [CrossRef]

el-Husseini, Rola. 2016. Is gender the barrier to democracy? Women, Islamism, and the "Arab spring". Contemporary Islam 10: 53-66. [CrossRef]

Ende, Werner. 2018a. Encyclopaedia of Islam. Edited by Peri Bianquis Bearman, Thierry Bosworth, Clifford Edmund, Emeri van Donzel and Wolfhart P. Heinrichs. Leiden: Brill.

Ende, Werner. 2018b. Encyclopaedia of Islam. Edited by Bianquis Bearman Peri Thierry. Leiden: Brill.

Finnbogason, Daniel, Göran Larsson, and Isak Svensson. 2019. Is Shia-Sunni Violence on the Rise? Exploring New Data on Intra-Muslim Organised Violence 1989-2017. Civil Wars 21: 25-53. [CrossRef]

Forward, Martin. 2001. Inter-Religious Dialogue: A Short Introduction. Oxford: Oneworld.

Guerrand-Hermès Foundation for Peace. 2018. Primary Interfaith Organizations. Available online: http: //interfaith.directory/organizations (accessed on 1 September 2018).

Haddad, Fanar. 2014. A Sectarian Awakening: Reinventing Sunni Identity in Iraq After 2003. Current Trends in Islamist Ideology 17: 70-101. [CrossRef]

Haddad, Fanar. 2017. 'Sectarianism' and Its Discontents in the Study of the Middle East. The Middle East Journal 71: 363-82. [CrossRef]

Halafoff, Anna. 2013. Encounter as Conflict: Interfaith Peace-Building. In Understanding Interreligious Relations. Edited by David Cheetham, Douglas Pratt and David Thomas. Oxford: Oxford University Press, pp. 262-80.

Hariri, Jacob Gerner. 2015. A Contribution to the Understanding of Middle Eastern and Muslim Exceptionalism. The Journal of Politics 77: 477-90. [CrossRef]

Hasheemi, Nader, and Danny Postel. 2017. Sectarianization: Mapping the New Politics of the Middle East. London: C. Hurst \& Co. Ltd.

Haynes, Jeff. 2001. Transnational religious actors and international politics. Third World Quarterly 22: 143-58. [CrossRef]

Haynes, Jeffrey. 2007. Religion and Development: Conflict or Cooperation? Basingstoke: Palgrave Macmillan.

Hinnebusch, Raymond. 2016. The Sectarian Revolution in the Middle East. Revolutions: Global Trends \& Regional Issues 4: 120-52.

Huntington, Samuel P. 1996. The Clash of Civilizations and the Remaking of World Order. New York: Simon \& Schuster.

Johnstone, Naomi, and Isak Svensson. 2013. Believers and Belligerents: Exploring Faith-Based Mediation in Internal Armed Conflicts. Politics, Religion E Ideology 14: 557-79.

KAICIID. 2018. KAICIID Peace Map. Vienna: King Abdullah Bin Abdulaziz International Centre for Interreligious and Intercultural Dialogue.

Keynoush, Banafsheh. 2016. Saudi Arabia and Iran: Friends or Foes? New York: Palgrave Macmillan.

Kubicek, Paul. 2015. Political Islam \& Democracy in the Muslim World. Boulder: Lynne Rienner Publishers, Inc.

Lakoff, Sanford A. 2004. The Reality of Muslim Exceptionalism. Journal of Democracy 15: 133-39. [CrossRef]

Larsson, Göran. 2016. One cannot doubt the potential effect of these fatwas on modern Muslim society. Online Accusations of Disbelief and Apostasy: The Internet as an Arena for Sunni and Shia Muslim Conflicts. Studies in Religion-Sciences Religieuses 45: 201-21. [CrossRef]

Lenderking, Timothy, Perry Cammack, Ali Shihabi, and David Des Roches. 2017. The GCC Rift: Regional and Global Implications. Middle East Policy 24: 5-28. [CrossRef]

Lynch, Marc. 2013. The Entrepreneurs of Cynical Sectarianism. Available online: https://foreignpolicy.com/2013/ 11/13/the-entrepreneurs-of-cynical-sectarianism/ (accessed on 20 September 2019). 
Mabon, Simon. 2015. Saudi Arabia and Iran: Power and Rivalry in the Middle East. London and New York: Ib Tauris $\&$ Co Ltd.

Mabry, Tristan James. 2015. Nationalism, Language, and Muslim Exceptionalism, 1st ed. Philadelphia: University of Pennsylvania Press.

Maréchal, Brigitte, and Sami Zemni. 2013. The Dynamics of Sunni-Shia Relationships: Doctrine, Transnationalism, Intellectuals and the Media. London: Hurst \& Company.

Marshall, Katherine. 2013. Global Institutions of Religion: Ancient Movers, Modern Shakers. London: Routledge, vol. 75.

Mason, Robert. 2014. Foreign Policy in Iran and Saudi Arabia, Economics and Diplomacy in the Middle East. London and New York: I.B. Tauris.

Moyaert, Marianne. 2013. Interreligious Dialogue. In Understanding Interreligious Relations. Edited by David Cheetham, Douglas Pratt and David Thomas. Oxford: Oxford University Press, pp. 193-217.

Nasr, Vali. 2007. The Shia revival. Military Review 87: 9-13.

Pew Forum. 2012. The World's Muslims: Unity and Diversity. Available online: http://www.pewresearch.org/wpcontent/uploads/sites/7/2012/08/the-worlds-muslims-full-report.pdf (accessed on 18 September 2018).

Pew Forum. 2013. Many Sunnis and Shias Worry About Religious Conflict. Available online: http://www.pewresearch.org/wp-content/uploads/sites/7/2013/11/Shias-Sunnis-religious-conflictfull-report.pdf (accessed on 18 September 2018).

Phillips, Christopher, and Morten Valbjørn. 2018. 'What is in a Name?': The Role of (Different) Identities in the Multiple Proxy Wars in Syria. Small Wars \& Insurgencies 29: 414-33.

Polka, Sagi. 2013. Taqrib al-Madhahib-Qaradawi's declaration of principles regarding Sunni-Shi'i ecumenism. Middle Eastern Studies 49: 414-29. [CrossRef]

Rathore, Shahzeb Ali. 2017. The Saudi-Iran Factor in Pakistan's Sunni-Shia Conflict. Available online: https: //www.mei.edu/publications/saudi-iran-factor-pakistans-sunni-shia-conflict (accessed on 20 September 2019).

Rowley, Charles K., and Nathanael Smith. 2009. Islam's Democracy Paradox: Muslims Claim to like Democracy, so Why Do They Have so Little? Public Choice 139: 273-99. [CrossRef]

Salloukh, Bassel F. 2017. The Sectarianization of Geopolitics in the Middle East. In Sectarianization: Mapping the New Politics of the Middle East. Edited by Nader Hasheemi and Danny Postel. London: C. Hurst \& Co. Ltd.

Sayigh, Yezid. 2017. The Arab Region at a Tipping Point: Why Sectarianism Fails to Explain the Turmoil. In Sectarianization: Mapping the New Politics of the Middle East. Edited by Nader Hasheemi and Danny Postel. London: C. Hurst \& Co. Ltd, pp. 53-60.

Seerat, Rustam Ali. 2017. Sectarian War Is Looming Over Afghanistan. Available online: https://thediplomat.com/ 2017/08/sectarian-war-is-looming-over-afghanistan/ (accessed on 20 September 2019).

Sharma, Kunaal. 2016. What Causes Extremist Attitudes Among Sunni and Shia Youth? Evidence from Northern India. Washington: Program on Extremism.

Sharqieh, Ibrahim. 2012. Can the organization of Islamic cooperation (OIC) resolve conflicts? Peace and Conflict Studies 19: 219-36.

Sisk, Timothy D. 2017. Conclusion: Peacebuilding in Sectarianized Conflicts: Findings and Implications for Theory and Practice. In Sectarianization: Mapping the New Politics of the Middle East. Edited by Nader Hasheemi and Danny Postel. London: C. Hurst \& Co. Ltd, pp. 259-76.

Smock, David R. 2002. Religious perspectives on War: Christian, Muslim, and Jewish Attitudes toward Force, rev. ed. Washington: United States Institute of Peace Press.

Smock, David R. 2006. Religious Contributions to Peacemaking: When Religion Brings Peace, not War. Washington: Institute of Peace, Peaceworks.

Sørli, Mirjam E., Nils Petter Gleditsch, and Håvard Strand. 2005. Why Is There so Much Conflict in the Middle East? Conflict Resolution 49: 141-65. [CrossRef]

Stepan, Alfred, and Graeme B. Robertson. 2003. An "Arab" more than "Muslim" electoral gap. Journal of Democracy 14: 30-44. [CrossRef]

Sunday, Orji. 2019. Nigeria's Shia Protesters: A Minority at Odds with the Government. Available online: https://www.aljazeera.com/indepth/features/nigeria-shia-protesters-minority-odds-government190421221658598.html (accessed on 20 September 2019). 
Sundberg, Ralph, Kristine Eck, and Joakim Kreutz. 2012. Introducing the UCDP Non-State Conflict Dataset. Journal of Peace Research 49: 351-62. [CrossRef]

Svensson, Isak, and Desirée Nilsson. 2018. Disputes over the Divine. The Journal of Conflict Resolution 62: 1127-48. [CrossRef]

Swidler, Leonard. 2013. The History of Inter-Religious Dialogue. In The Wiley-Blackwell Companion to Inter-Religious Dialogue. Edited by Catherine Cornille. Chichester, West Sussex and Malden: Wiley Blackwell, pp. 3-19.

Varshney, Ashutosh. 2002. Ethnic Conflict and Civic Life: Hindus and Muslims in India. New Haven: Yale University Press.

Wehrey, Frederic M. 2017. Beyond Sunni and Shia: The Roots of Sectarianism in a Changing Middle East. London: C Hurst \& Co Publishers Ltd.

Worrall, James. 2017. International Institutions of the Middle East: the GCC, Arab League, and Arab Maghreb Union. Abingdon and New York: Routledge.

(C) 2019 by the authors. Licensee MDPI, Basel, Switzerland. This article is an open access article distributed under the terms and conditions of the Creative Commons Attribution (CC BY) license (http://creativecommons.org/licenses/by/4.0/). 



\title{
Catholic Mediation in the Basque Peace Process: Questioning the Transnational Dimension
}

\author{
Xabier Itçaina ${ }^{1,2}$ \\ 1 CNRS - Centre Emile Durkheim, Sciences Po Bordeaux, 11 allée Ausone, 33607 Pessac, France; \\ x.itcaina@sciencespobordeaux.fr \\ 2 GEZKI, University of the Basque Country, 20018 San Sebastian, Spain
}

Received: 30 March 2020; Accepted: 17 April 2020; Published: 27 April 2020

\begin{abstract}
The Basque conflict was one of the last ethnonationalist violent struggles in Western Europe, until the self-dissolution in 2018 of ETA (Euskadi ta Askatasuna, Basque Country and Freedom). The role played by some sectors of the Roman Catholic Church in the mediation efforts leading to this positive outcome has long been underestimated, as has the internal pluralism of the Church in this regard. This article specifically examines the transnational dimension of this mediation, including its symbolic aspect. The call to involve the Catholic institution transnationally was not limited to the tangible outcomes of mediation. The mere fact of involving transnational religious and non-religious actors represented a symbolic gain for the parties in the conflict struggling to impose their definitions of peace. Transnational mediation conveyed in itself explicit or implicit comparisons with other ethnonationalist conflicts, a comparison that constituted political resources for or, conversely, unacceptable constraints upon the actors involved.
\end{abstract}

Keywords: Basque conflict; nationalism; Catholic Church; Holy See; transnational mediation; conflict resolution

\section{Introduction}

The Basque conflict was one of the last ethnonationalist violent struggles in Western Europe, until the definitive ceasefire (2011), decommissioning (2017), and self-dissolution (2018) of the armed organization ETA (Euskadi ta Askatasuna, Basque Country and Freedom). The alleged definitive end of political violence has opened a two-fold debate in the Basque, Spanish, and French public spheres. The first dimension relates to the political and judicial consequences of the ending of the armed struggle, classically termed as "negative peace": decommissioning, rapprochement, release and reintegration of prisoners, and judicial treatment of victims. The second dimension deals with post-violence and the building, as a medium-term objective, of a "positive peace" (Brewer et al. 2011): work with victims and victim support groups; dealing with memory; dealing with the issues of hope, forgiveness, and reconciliation; and reintegration of protagonists. The memorial aspect holds a special importance in the Basque case with the opening of a new political arena around the competing narratives of the conflict over both its recent and its more ancient history (Tellidis 2018; Muro 2011). The post-2011 "batalla del relato" (battle of narratives), which is now taking place in social, media, political, academic, and fictional (Madina et al. 2018) fields opposes competing interpretations of the history and consequences of the conflict. Among other aspects, the role played by religion in general and by the Catholic Church in particular, both in the conflict and in its resolution, has now come back to the fore (Ontoso 2019). At first glance, this enduring politicization of religion, whether as part of the "problem" or of the "solution" to the political conflict, or both, is quite unexpected in the context of a very secularized society, such as Basque society. Religion is still deemed to play an important role in Basque society and politics, while churches are still empty and the proportion of priests per inhabitant has never been so low. Sociologists of religion have pinpointed the Basque Country as evidence of the third wave of secularization of 
Spain (Pérez-Agote 2012). Unlike the decatholicization or "mix and match" stage, which marked the second wave of secularization, secularization has entered into a phase of exculturation (Hervieu-Léger 2003), during which culture is gradually losing its Catholic roots. Moreover, in the Basque Country, this process has been exacerbated, according to Pérez-Agote (2006), by a kind of substitution of religion by politics and the national question as new social centralities. Yet, any intervention by the Church in Basque politics remains highly politicized.

This article aims to explore this paradoxical contrast between the perceptions of the Catholic Church as a relevant sociopolitical actor and the weakening of its social grip. This paradox is particularly intriguing in the role played by the Church in peacemaking. The relative leverage of Catholic actors in the peace process stemmed precisely from the secularization of politics and society in the Basque Country. The Church was seen as sufficiently detached from its former positions of power not to be suspected of hegemonistic ambitions, while also being perceived as a relevant social institution due to its territorial coverage, its expertise in peacemaking, and its presence in local welfare. This legitimacy is itself controversial due to the very institutional nature of the Church. As a memorial (Hervieu-Léger 1993; De Longcamp 2019) and a transnational institution, the Church embodies the memory of a longstanding relationship between Catholicism and Basque politics. Therefore, the Church's discourse and praxis on peace are highly exposed to politicization and publicization in times when historical narratives of the conflict are competing with each other.

The Catholic Church has also been perceived by Basque social and political actors as a legitimate actor in peacemaking due to its transnational influence. Basque political actors, in particular, seem to have perfectly understood the political ambivalence of the Church:

at the one hand, it remains a quintessentially conservative body with a hierarchical organization designed to preserve traditional theological teachings. This impulse produces conservative stances on sexual morality, abortion, and marriage, and puts the Church in alliance with other religious traditionalists, including Muslims. On the other hand, Catholic teaching on the dignity of the human person and the authenticity of the common good produce concern for the poor in the global economy and, specially [sic] in recent decades, advocacy of religious freedom, human rights, and democratic governance. (Hertzke 2016, p. 36).

In this respect, the transnational Catholic expertise on peacemaking, whether through the Holy See itself or through NGOs such as Sant'Egidio, has been regularly sought by political actors all over the world (Appleby et al. 2010). Building on Haynes' distinction between transnational and global civil society (Haynes 2012), Shani (2016) argues that transnational religious actors (in his case, Catholics and Sikhs) have the potential to collectively constitute an embryonic globalized transnational civil society as an alternative both to the Westphalian international order and to the secularized liberal model of global civil society. The Catholic Church would thus be part of a "post-secular" transnational civil society referring to "a network or coalition of non-state actors representing the interest of different transnational secular or religious communities, sharing a common interest in working together to overcome the challenges posed by globalization and the Westphalian states system" (Shani 2016, p. 300).

This potentially challenging role of the Church with respect to the Westphalian states system might be turned into an opportunity for "nations without states". This is especially the case if, as John Paul II did in his address to the United Nations General Assembly in 1995, the Catholic reference to human rights is interpreted as going together with a reference to peoples' and nations' rights. Such a perception, however, has been put to the test with the ambivalent transnational political role of the Church. Ferrari (2006) has framed the Catholic Church as being both a sovereign state and an NGO relying on soft power to achieve its aims, with a billion members all over the world. Barbato (2013) has emphasized the "multi-layered actorness" of the Holy See and of the Pope, who acts simultaneously as a head of state, as an international diplomat, and as the leader of a transnational religious community. In this sense, Barbato argues, the soft power of the Pope is based on the Holy See's ability to act in a multilevel game. As we will see with the Basque case, if in some circumstances the Church may act as a transnational actor fostering the values of solidarity, social justice, and peace in its interpretation 
of globalization, in other cases the Holy See can play a more conventional diplomatic role by acting as a "peer in a society of states" (Barbato 2013, p. 39), without necessarily challenging the existing state system.

In that respect, while the-itself controversial-role of the Church in the Basque Country in peacemaking has been scrutinized by various essays and from various standpoints (Placer Ugarte 1998; Bilbao Alberdi 2009; Cobos Romero 2018; Serrano Oceja 2001; Itçaina 2018), the transnational dimension of Catholic peacemaking in the conflict remains underexplored. Yet, the very institutional nature of the Catholic Church lies precisely in a hierarchical and social combination of its local and global dimensions. Without claiming to be exhaustive, in this essay, I engage with this transnational dimension. More specifically, in this paper, I examine the political work undertaken by the political institutions, parties, elites, and civil society organizations of the Basque Country since the mid-1990s in order to involve the transnational Church in conflict resolution and post-conflict rehabilitation. I do so by utilizing three bodies of literature: that on religion and peacemaking; that on Basque nationalism, political violence, and conflict resolution; and that on the sociology of political work and the making of public problems.

My main argument can be summarized as follows: the political result of this call to involve transnational Catholic institutions was not limited to the tangible outcomes (in terms of "success" or "failure") of mediation. Rather, the mere fact of involving transnational religious and non-religious actors represented a symbolic gain for the parties in the conflict struggling to impose their definitions of peace as a public problem. Thereupon, explicit or implicit comparisons with other ethnonationalist conflicts that have inevitably arisen from the appeal for transnational mediation have constituted either political resources for or, conversely, unacceptable constraints upon, the actors involved. The remainder of the article develops this argument in two stages. Section 2 focuses on the political work conducted, directly or indirectly, alongside the Holy See by the Basque autonomous government and by its main component, the Basque Nationalist Party (Partido Nacionalista Vasco, PNV), as part of its strategy of paradiplomacy. Section 3 shows that the call for transnational religious mediation was not monopolized by the Basque government or by the PNV and that it was performed by a wider array of Basque political parties and peace movements, thus involving different political and semantic uses of transnational comparisons. In my concluding remarks, I set out new hypotheses on the future of this plural relationship with transnational religious mediation in the context of post-violent Basque society.

In this article, I rely on qualitative research conducted among the Catholic organizations, peace groups, and political parties involved in the Basque conflict, on media analysis, and on original archive material regarding the relations between the Basque autonomous government and the Vatican authorities between 1996 and 2007. Additionally, a campaign of semi-directed interviews was conducted in the Spanish and French Basque Country. On the one hand, I made use of data collected in 1995 and in 2005-2006 with Cross-Border Coordination for Basque Country Priests (Euskal Herriko Apaizen Koordinakundea-EHAK), with the Franciscan monks at Arantzazu and Saint-Palais, with members of the Synod of Bayonne's Secretariat, and with Basque former priests and seminarians. I updated this research with a campaign of interviews carried out in 2012-2013 with the following personalities and organizations: Monsignor Uriarte, former Bishop of San Sebastián between 2000 and 2009; the vicar general of the Diocese of Bilbao; a theologian at the University of Deusto; an official at the Baketik (Peace) Centre at Arantzazu; Christian activists in the PNV; the former Delegate of the President of Euskadi for External Relations between 1990 and 2007; and the Socialist Party of the Basque Country—Basque Country Left (Partido Socialista de Euskadi-Euskadiko Ezkerra, PSE-EE), including a co-founder of the Cristianos en el socialismo (Christians in Socialism), the lay association Eutsi Berrituz (Hold Fast While Renewing) in San Sebastián, and the Fedea eta Kultura (Faith and Culture) Association in Bayonne. 


\section{The Expected Advocacy: The Holy See and the Paradiplomacy of the Basque Government}

\subsection{Informing and/or Involving Rome}

Even though most of the peace effort was performed by local civil society, the parties involved in the conflict also tried to involve transnational actors in conflict transformation, including religious actors. A first strategy consisted of Basque institutions and peace movements involving the Holy See itself. One of the most sustained efforts came from the Basque autonomous government. There were reasons for this strategy, starting with historical ones. Established in 1980 during the democratic transition, the Basque government was thereafter controlled, except between 2009 and 2012, by the $\mathrm{PNV}$, either alone or in coalitions. Even though the party officially gave up its denominational identity when it was legalized in 1977, the PNV, itself one of the oldest political parties in Europe (founded in 1895), had its roots in Christian democracy and was one of the founding members of the International Christian Democracy (Gilmour 2005). Due to this legacy, the PNV and the Basque government continued to attach importance to their relations with the Catholic Church, at both the local and global scales. The relationship between this sector of Basque nationalism and Rome was influenced by the former connection between Basque nationalism and Catholicism but was also tainted with mutual distrust given the support of the Vatican for Franco's regime. Despite this ambivalent memory, after 1980, the Basque government carried out political work in order, at the very least, to inform the Holy See about the conflict and, at the most, to involve it in the peace process.

Formally speaking, this strategy did not produce much of a result. The end of the armed struggle in 2011 was a conjunction of many causes-in particular, the loss of social support for violence and internal changes in the independentist left strategy_including the peace work performed by the local church, but the Holy See probably did not play a crucial role here. Roman institutions remained cautious about the Basque question, and no official mediation by Vatican officers was performed, at least publicly, during the violent years. Among other causes, pressure from the Spanish government, state-level political parties, associations of victims, and the Spanish Catholic hierarchy itself, prevented any formal involvement of Rome. However, despite this apparent failure, the political work undertaken by representatives of the Basque government alongside the Holy See testified to an enduring political effort with multiple dimensions.

In that respect, the conceptualization of political work by Smith (2016) may be helpful. According to this approach, political work refers to the strategies undertaken by actors to maintain or to change institutions, and it encompasses three interrelated aspects: the making of public problems, the construction of policy instruments, and the legitimization of both actors and instruments. The politics of the Basque government with respect to the Vatican did not manage to, or perhaps did not even aim to, involve the Holy See in direct mediation for conflict resolution/transformation/amelioration (McCall 2013). Nevertheless, the two remaining dimensions were crucial ones. The Basque government strove to report its reading of the Basque situation-i.e., an alternative reading to both the narrative of the Spanish government and that of the Basque independentist left. By doing so, the Basque government and the PNV sought to appear as the "owners" of the Basque "public problem" (Gusfield 1981), and their representatives worked to convey their interpretation to the Vatican.

\subsection{Three-Pronged Political Work}

This strategy was particularly obvious in the 1990-2000s and was mainly structured around three main issues.

A first set of issues related to the institutional organization of the Church in the Basque Country: the appointment of bishops and the request for a territorial reorganization of the Church. As early as 1992, José Antonio Ardanza, then president of the Basque government, wrote to Cardinal Sodano, State Secretary of the Holy See, asking him for a meeting in order to comment on the appointment of bishops in the Basque Country. In 1996, the appointment of a non-Basque-speaking bishop in Bilbao (Mons. Blázquez) raised concerns among Basque center-right nationalists. The Basque government 
also repeatedly supported (for instance in 1996-1997) the demand for a unique ecclesiastical province gathering the Basque dioceses. The answer of the State Secretary of the Holy See was always an institutional one, insisting on the universal nature of the Church- "there is no Basque Church, but a universal one" - and on the fact that the territorial organization of the (Spanish) Basque Church was under the jurisdiction of the Spanish Episcopal Conference. Intervening in this first set of issues raised a problem of jurisdiction for the Basque government. To what extent should a regional government have its say on internal church affairs? The discreet interventions of the Basque government found a justification in the importance of the Church in Basque society, thus disentangling the secularization of society and the ongoing social presence of the Church, particularly in local welfare.

A second set of issues concerned information about the Basque political conflict. Here, the Basque government's main concern was informing the Holy See on a regular basis and transmitting its own reading of the situation. The challenge for the government consisted in finding transnational support for the third way it defended, between the anti-terrorist and repressive stance of the Spanish government and the implicit support for political violence from the Basque independentist left. The repeated informal meetings between representatives of the Basque government and Holy See officials were above all to maintain channels of information rather than formal attempts to involve the Holy See.

"Informing" the Holy See, however, was far from simple, because it implied gaining enough legitimacy to access its top bureaucracy. Recognition was never taken for granted, due to political pressures and diplomatic rules. The fact that the Vatican Secretariat for Relations with States could maintain informal discussions with the representatives of a regional government was not self-evident. On the other hand, maintaining relations with the Vatican made sense in the broader picture of the paradiplomacy developed by the Basque government (Totoricagüena 2005; Aldecoa and Keating 1999). Opening an informal channel of communication with a subject of international law such as the Holy See was a way for the Basque government to behave as a state while being a non-central government actor. Here, as elsewhere (Lecours and Moreno 2003), the link between stateless nationalism and paradiplomacy was conditioned by domestic and international opportunity structures.

Usually discreet and "contained" (Gilbert and Henry 2012), these exchanges of information could be publicized and politicized at critical junctures. In September 2000, the canonization of María Josefa del Corazón de Jesús Sancho de Guerra Maria, founder of the Servants of Jesus of Charity, gave rise to such a controversy. As the future saint was a native of the Spanish Basque Country (Vitoria, 1842-Bilbao, 1912), the ceremony brought to Rome a significant Basque delegation, including political leaders. Among them was Juan José Ibarretxe, at that time president of the Basque government. The lehendakari (president) took advantage of the situation and was received by Mons. Jean-Louis Tauran, then Secretary of Relations with States of the Holy See, a meeting that in itself raised an institutional issue:

"He [Tauran] had no obligation to receive Ibarretxe, since he was the Secretary of Relations with States of the Holy See. Then of course, one might consider that the lehendakari is State. Es Estado. España. He is part of the state. In the territory of the Basque Country, he is the representative of the government and of the Spanish state. We can consider it that way. But anyone who would interpret it strictly might say: no. He is not a representative of the state. Besides, there was a minister who was there. Mayor Oreja. So Mons. Tauran would have had a legitimate excuse to say no."1

Apart from this meeting, Ibarretxe took part, along with the delegation organized by the Spanish Embassy, in the ceremony of canonization presided by the Pope on 1 October 2000. The next day, Ibarretxe went to Florence and met with Vannino Chiti, State Secretary for the Presidency of the Italian Council of Ministers, and Claudio Martini, president of the Tuscany Region. After the meeting, Martini

1 Delegate of the President of Euskadi for external relations of the Basque government. Author interview, Segura, April 2012. 
called on the European Union to "help in the process" leading to peace in the Basque Country. ${ }^{2}$ The Vatican meeting, for its part, caused controversy in the Spanish media surrounding the ambiguity of the "contribution" to pacification in the Basque Country proposed by the Holy See, though Ibarretxe himself had remained very cautious. He was reported to have given Mons. Tauran a "non-distorted" analysis of the situation in the Basque Country and to have handed him a copy of the peace plan that he had delivered to the Basque political parties. Ibarretxe thanked the Holy See for its offer, a "contribution which will be channeled through the work done by the Basque bishops". ${ }^{3}$

The subtle distinction between the Holy See's offer of a "contribution" rather than "mediation" led to diverging interpretations. The Spanish Church did not react officially, stating that should any mediation effort emanate from the Holy See, it would necessarily transit through the Spanish Catholic hierarchy. ${ }^{4}$ The Spanish government made it clear that there had not been any proposal of mediation in the conversation held by Mons. Tauran on this occasion with Jaime Mayor Oreja, then Spanish Minister of Home Affairs. ${ }^{5}$ Josep Piqué, Minister of Foreign Affairs, made it clear that the Holy See had limited itself to a "generic offer" of collaboration and that the Holy See could not act as an intermediary "between a democratic state and murderers". ${ }^{6}$ The Spanish right (Popular Party, $\mathrm{PP}$ ) and left (PSOE, Spanish Socialist Party) centralist parties released similar declarations, while the Basque center-right (PNV) and social-democrat (Eusko Alkartasuna-EA) parties welcomed what they perceived as a "proposal" from the Holy See. Given the controversy, the Holy See deemed it proper to clarify the issue by specifying that there was no question of mediation but instead "the contribution that the Catholic Church could continue to offer" in the search for a solution to the "terrorist" problem in the Basque Country. ${ }^{7}$

Beyond the controversies, the episode above highlights the symbolic sensitivity of the involvement of the Holy See in a domestic conflict. The mere fact that the Secretary of Relations with States of the Holy See had maintained separate conversations with a state minister and with the head of a regional government could be perceived as a symbolic gain for the Basque authorities. The interview that the Basque president was supposed to give on Radio Vatican was cancelled, as it was considered "inappropriate" by the State Secretary of the Holy See. Secondary questions of etiquette took on a symbolic meaning: Ibarretxe and Mayor Oreja were sitting side by side during the ceremony of canonization, an equal status, which was seen as problematic by observers. ${ }^{8}$ For the Basque leader, the domestic context necessitated such an additional legitimacy. The context in the Basque Country had become tense again since the end of ETA's 14-month ceasefire in December 1999. The week after the canonization, the Basque Parliament had to hold a debate on a confidence motion filed by the PP, with the support of PSOE, against Ibarretxe. The few words pronounced in Basque ${ }^{9}$ and in Spanish by the Pope during the ceremony also left room for diverging interpretations. The right-wing Spanish press saw this intervention as a clear condemnation of ETA and its supporters. ${ }^{10}$ The Basque media, meanwhile, stressed the call for peace and reconciliation in the papal message.

Similar debates took place after ETA's announcement of a ceasefire on 22 March 2006. On 3 April 2006, Monsignor Uriarte, then Bishop of San Sebastián, presented to the Vatican the efforts made by

\footnotetext{
Deia, 4 October 2000.

Deia, 3 October 2000.

"El Vaticano se ofrece para buscar una 'solución pacífica' en el País Vasco", El Mundo, 3 October 2000.

El País, 3 October 2000.

"El Vaticano asegura que no ha propuesto una mediación para lograr la paz en el País vasco", Diario Vasco, 4 October 2000. Ibid.

Additional problems of etiquette were reported by the Spanish ambassador to the Holy See in his memoirs (Abella y Ramallo 2006).

9 "May the model and the intermediation of saint María Josefa del Corazón de Jesús help the Basque Country in eradicating violence forever, and in turning the blessed land of Euskadi into a place for peaceful living together and fraternity, where the rights of all persons will be respected and where no innocent blood will ever be shed again" (Holy See press office, Bollettino, sala stampa della Santa Sede, ${ }^{\circ}{ }^{\circ} 568,1.10 .2000$, my translation from Basque).

10 La Razón, 2 October 2000.
} 
the Church of the Basque Country in favor of peace. Two days later, Pope Benedict XVI exhorted the congregation gathered in Saint Peter's Square "to pray that everybody will intensify their efforts for the consolidation of the horizons of peace that seem to be appearing in the Basque country and in Spain, and to overcome the obstacles that might appear" ${ }^{\prime 11}$. Despite a cautious attitude-promoting peace is not mediating in the conflict-the intervention of the Pope had a symbolical impact, as it helped put the Basque issue on the universalistic Catholic agenda. However, hope for a peaceful resolution of the conflict vanished when ETA resumed its violent campaign in December 2006.

A third set of issues referred to the historical memory of the longstanding relationship between the Basque political conflict and the Catholic Church. Revisiting the role of the Church and of the Holy See at the critical junctures of the Basque conflict acquired a new significance when memory issues again came to the fore in Spain in the 2000s (Leonisio et al. 2015, pp. 163-231). The PNV and the Basque government attached the utmost importance to the memory of the Spanish Civil War and its consequences, thus referring to the enduring contention about the divided positions of the Church. As evidenced by Molina (2011), the debate on the Basque Statute during the Spanish Second Republic (1931-1939) had become an exceptional political myth in contemporary Basque politics. According to current political narratives of Basque identity, the traditional will for self-government among the Basque people was expressed during those years in a wide-ranging demand for autonomy and identity. In contrast, Molina argues, the social complexity of the autonomy project was more related to religion than to ethnic conflict. Thus, this re-enacting of the past and the role of the Church held special significance in the context of the enduring political tensions of the 1990-2000s. In 1996, in the context of a debate about the Basque Church province, the Delegate of the President of Euskadi for External Relations took the initiative of sending Mons. Etchegaray, a French Basque cardinal who was at the core of the "hybrid mode of diplomatic agency" (Troy 2018) of the Holy See, ${ }^{12}$ a report by the Sabino Arana Foundation on the 1936 visit of the delegation of the Basque government to the Vatican. During this visit, Mons. Pizzardo, Secretary for Extraordinary Ecclesiastical Affairs, had asked President Aguirre to ally with the right-wing CEDA, ${ }^{13}$ a proposal that the Basque government eventually declined. In July 2002, the Delegate of the President of Euskadi sent Juan José Asenjo Pelegrina, General Secretary of the Spanish Episcopal Conference, a copy of the letter Imperativos de mi conciencia [Imperatives of my conscience] written in 1945 by Mons. Mugica, former bishop of Vitoria, explaining the positions of the Basque Church during the Civil War. Such a personal missive took on special meaning in 2002 in the midst of a controversy surrounding the pastoral card "Preparing peace", released by the bishops of the Basque Autonomous Community. The bishops' pastoral letter expressed reservations about the new Spanish electoral law on political parties, which had been designed by PP and PSOE to outlaw the Basque independentist party Batasuna. Even if it was not meant to establish any hazardous parallel between the Civil War and the 2002 situation, this historical reminder took on special signification in this context. Further episodes contributed to reactivating memorial issues. In 2007, the Holy See beatified 498 Spanish priests and clerics killed by the republicans during the Spanish Civil War. This decision aroused controversy in the Basque Country, in Spain, and abroad, ${ }^{14}$ against the backdrop of the approval of the Law on Historical Memory prepared by the socialist government in order to rehabilitate the victims of Franco. Basque nationalists lamented two major shortcomings. The first was the omission of the 16 Basque priests and thousands of republicans and democrats, among them many Catholics, who had been murdered by Franco's troops during the Civil War. The second referred to the

11 Quoted in Luis R. Aizpeolea, "El Papa apoyó el proceso de paz tras la mediación del obispo Uriarte ante el Vaticano", El País, 22 October 2006.

12 Roger Etchegaray had been president of the Pontifical Council Cor Unum between 1984 and 1995 and of the Pontifical Council for Justice and Peace between 1984 and 1998. Between 1979 and 2005, Etchegaray carried out several diplomatic missions on behalf of the Pope in Cuba, Rwanda, Jerusalem, China, and Iraq.

13 Confederación Española de Derechas Autónomas-Spanish Confederation of Autonomous Rightist Groups.

14 "Le Pape s'invite dans le débat sur la guerre civile espagnole", La Croix, 27 octobre 2007. 
support of the Spanish Church and of the Holy See for Franco's regime (Iztueta 1981) ${ }^{15}$. Again, this took on special significance in the context of the Spanish memorial debate.

To sum up, the political work led by the Basque government with the Holy See during the years of political violence presented three main characteristics. Firstly, it consisted above all in informal and discreet awareness-raising of the Holy See about the Basque government's view on Basque politics. Secondly, the efficiency of this work rested upon the key role of individual agency. In the 1990-2000s, the Delegate of the President of Euskadi for External Relations, himself a committed Catholic, played a pivotal role in establishing and maintaining, as personal and informal initiatives, this relationship with the Vatican Secretary of State. Thirdly, despite the significant presence of Basque priests and clerics in the Vatican hierarchy, this factor was not necessarily decisive in the Basque government's paradiplomacy efforts in Rome. Significantly, Mons. Etchegaray (1922-2019), while being central to Vatican diplomacy, remained cautious on the Basque question despite having his views regularly sought by Basque political and social actors. Following Smith (2016) concept of political work, we might conclude that despite its weak results in terms of new policy instruments on conflict resolution, the advocacy led by the Basque government toward the Holy See did result in the sharing of its problematization of the Basque conflict and in enhancing its own legitimacy as a substate and transnational political subject.

\section{Looking after Rome from the Left: Plural Mediations in a Deregulated Peace Market}

\subsection{A Functional Perception of Religious Intermediation}

The transnational mediation by the Catholic Church, and more broadly speaking by religious actors in the Basque conflict, was not monopolized by this first communication channel. Distinct sectors of the Basque political spectrum sought specific religious actors for their intermediation capacity. Even the Basque nationalist left, which had an anticlerical component, as well as many peace movements, were open to some form of intermediation by religious actors. Unlike the PNV, this call did not rely on a Christian democrat legacy or on a doctrinal convergence but, rather, on a functional view of religious actors as experts in peacemaking.

Transnational mediation was particularly necessary during ETA ceasefires and negotiation periods. This was the case when the Socialist Party came into power in Spain in March 2004 with more open positions with respect to negotiations on the Basque case. ${ }^{16} \mathrm{~A}$ two-pronged process then followed, the second round of which clearly staged the functional perception of religious intermediation by political actors. A first round of meetings, in Oslo and Geneva under the aegis of the Henri Dunant Centre, put ETA envoys in contact with the Spanish government. A second round of negotiations took place between three Basque political parties: Batasuna (at the time illegal in Spain), the Basque Socialist Party (PSE-EE-Partido Socialista de Euskadi-Euskadiko Ezkerra), and the PNV. This political roundtable comprised a dozen meetings in the Jesuit sanctuary of Loyola. Had an agreement been reached between the three parties, an original copy would have been given to the Vatican for safekeeping (Murua 2010, pp. 67, 133; Murua 2017). ${ }^{17}$

Unlike the PNV, this attitude was less expected of the two left-leaning parties. During the 2004-2005 conversations between Batasuna and PSE-EE, Basque leaders of both parties (respectively,

15 The Delegate of the President of Euskadi sent a letter in that sense to Mons. Dominique Mamberti, Secretary for Relations with States at the Holy See, 12 November 2007 (personal archive).

16 The process of opening lines of communication with ETA was endorsed by the Spanish Parliament on 17 May 2005.

17 According to Murua (2010), PSE-EE finally preferred to entrust it to the Society of Jesus. The parties' envoys were close to reaching an agreement on a text written in October 2006. This set out a scenario for an end to the crisis through a progressive alliance between Navarre and the Basque Autonomous Community, which would be subject to a referendum. However, the amendments introduced by Batasuna, followed by those of the PSE-EE, rendered the possibility for an agreement null and void. The ETA attack on Barajas Airport on 30 December 2006 sealed this failure, despite last-ditch meetings between the political and military wings in Geneva under the aegis of the Henri Dunant Centre in 2007. 
Arnaldo Otegi and Jesus Eguiguren) turned to the Church in order to facilitate contacts between ETA and the new government because of its transnational dimension. For Eguiguren, "the idea was to look for external mediation; and the Church was as an independent state; so if we wanted to talk with the Church, we had to go to Rome" (Eguiguren and Aizpeolea 2011, p. 32, my translation). Eguiguren met Etchegaray, but the French Basque cardinal kept the same distance as he had done before with the Basque government. He sent them back to his Basque counterparts and repeated that "the Holy See confirms, if things go well, but never baptizes" (Eguiguren and Aizpeolea 2011, p. 34, my translation). Given the stalemate in transnational mediation, Otegi and Eguiguren came back to the domestic Church. Interestingly, the Batasuna leader insisted on involving Mons. Uriarte, then bishop of San Sebastián, in the mediation, not because of his neutrality as a mediator but, on the contrary, because of his presumed proximity with the PNV and the Basque government, assuming that one would bring the other into the discussions. In this case, the legitimacy and credibility of the religious mediator did not stem from his position as an outsider but, as evidenced by Wehr and Lederach (1991) in Latin America, from his position as an insider, who could move peacemaking forward due to his profound understanding of the actors and the issues. Uriarte himself advised socialist and Batasuna leaders that local and direct mediation would probably be the most effective method. ${ }^{18}$

As noted by a major expert on the Basque conflict and peacemaking, himself a former leader of the Elkarri peace movement, the fact that the independentist left always maintained relations with the Church also revealed some kind of overestimation of the power of influence of the religious institution, especially on the transnational side:

Curiously enough, the abertzale [Basque nationalist] left has maintained a strong relation with Uriarte [bishop of San Sebastián]. Significant leaders Arnaldo Otegi, Rafa Diez and Rufi Etxebarria have always maintained regular relations with Uriarte. And I would say that this is still the case. This in the case of the abertzale left. In the case of the PNV, the syntony was greater. Which is logical. But all of them maintained contacts. Additionnally, the abertzale left has always considered that the Vatican has this important power, almost magical, international influence, and so on. For instance, he is now very old, but there was Mons. Etchegaray, the French Basque cardinal, who had been very active in his time. All this rendered the role of the church very attractive to the abertzale left. ${ }^{19}$

In its further attempts, the independentist left kept on searching for transnational mediators as a political strategy to transnationalize the conflict settlement. If religious elites were mobilized and/or accepted as mediators by the abertzale left, it was due to their expertise in peacemaking, but also, and maybe above all, in view of their potential contribution to this process of transnationalization of the cause. This strategy was particularly obvious between 2010 and 2018, in the various sequences of events leading to the end of ETA. As mentioned earlier, this process resulted from the combination of many factors: police repression, loss of popular support for violence, and a strategic change within the independentist left regarding political violence. The peacemaking efforts, and notably their transnational dimension, also played a significant role in this respect (Whitfield 2014).

\subsection{The Global Church and the Political Work around Transnational Comparison}

Even if it remains hazardous to measure the contribution of mediation to the end of violence, one can be more confident about the political uses of transnational mediation by Basque nationalism in general and by the independentist left in particular. The mere fact of framing the end of the armed struggle as a "peace process" involved an implicit and semantic comparison with other violent conflicts all over the world. Transnational mediation appeared to be a strategic resource for the nationalist

18 Taking into consideration that, on the global scale, the Basque conflict, as a low-intensity conflict, was probably seen as a minor issue by the Holy See (Mons. Uriarte. Author's personal interview, Bilbao, 2012).

19 Director of the Baketik peace center. Author's personal interview, Arantzazu, August 2012, translated from Basque. 
left struggling to frame the end of ETA as a step in a "peace process", i.e., one that implied a political contention and not merely a question of public order that would be solved through judicial and police measures (Zulaika and Murua 2017). This strategic use of comparison consisted first in involving the European institutions in the conflict settlement, with the Irish precedent in mind, thus updating an old strategy (Bourne 2003). The opposition of Spain restricted this involvement, which remained limited to the constitution of a support group for the Basque peace process in the European Parliament.

Given the lack of involvement of the EU and - at least publicly—of the states concerned, the actors of the Basque "peace process" turned to non-institutional forms of mediation, within and outside the EU. Zulaika and Murua (2017) labeled this role of international actors in the Basque process "virtual diplomacy". The announcement of the definitive end of its armed activities by ETA on 5 September 2010 was released in the wake of the Brussels Declaration in favor of the peace process. Presented to the European Parliament on 30 March 2010, the resolution was signed by a prestigious panel of international leaders, among them four Nobel Peace Prize winners (Frederick De Klerk, Desmond Tutu, John Hume, and Betty Williams), a former Irish Taoiseach (Albert Reynolds), a former general secretary of Interpol (R. Kendall), the Nelson Mandela Foundation, etc. On 20 October 2011, ETA announced the definitive end of its armed activities, two days after the International Peace Conference held at Aiete (San Sebastián) and organized by the citizen peace organization Lokarri, the Berghof Foundation, the Conciliation Resources, the Norwegian Peacebuilding Resource Center, the International Contact Group (ICG), and a team of top-tier international mediators. ${ }^{20}$ By September 2011, an International Verification Committee (CIV) had been constituted, composed of political leaders and experts engaged in conflict resolution in such diverse regions as South Africa, Northern Ireland, Sri Lanka, Kosovo, and Iraq. The CIV monitored the steps in the decommissioning of ETA through to the neutralization of the military arsenal of the organization on 8 April 2017 in the French Basque Country. The mobilization of such a range of international mediators reflected the quest for legitimacy of Basque peace groups, who aimed to circumvent the lack of involvement of the Spanish and, to a much lesser extent, French states. This strategy was also a way to stage an honorable way out for a weakened armed organization.

Zulaika and Murua (2017) proposed a thought-provoking reading of the involvement of the international community by using a theatrical metaphor. They argue that Aiete's "theatrical tolerance" (Zulaika and Murua 2017, p. 352) was particularly useful for the nationalist left "in that it turned the presence of the Spanish State into a sideshow, while it was the international community that acted as the ultimate witness" (Zulaika and Murua 2017, p. 352). Again, semantic debates were at the heart of this process: "indeed, even calling it a 'conflict' is a misnomer and an anathema for much of the Spanish elites and media." (ibid.). However, the attitude of the Spanish state varied according to the political color of its government: "Zapatero's government realized that the end of terrorism required international actors, and allowed for them while keeping a distance from them. This added the sense of 'theatre' and 'comedy' to the entire dialogue process that was officially denied while it was taking place" (Zulaika and Murua 2017, p. 352). The post-November 2011 PP government returned to harder positions with regard to the process and distanced itself from the confidential roadmap that had been drafted by the international facilitators.

Transnational religious actors were not at the core of this process. However, and together with the local church, some religious organizations and individuals had been involved in various attempts at mediation, before and after ETA's definitive ceasefire. The community of Sant'Egidio, known for its expertise in peacemaking (Holmsen 2018), had already attempted to mediate between ETA and the Spanish government in 1998 (Whitfield 2014, p. 93). Some attempts by the Society of Jesus were also reported in 1984 (Garaikoetxea 2002, pp. 179-80). The proximity of the Irish and Basque conflicts and the mutual strategic uses of comparison by activists (Espiau Idoiaga 2010; Alonso 2004; Bew et al. 2009; Bourne 2003) led a few religious mediators to circulate from one conflict to the other. In 2002, in a tense

20 Kofi Annan, Gro Harlem Bruntland, Bertie Ahern, Gerry Adams, Jonathan Powell, and Pierre Joxe. 
political context due to the outlawing of Batasuna in Spain, new discussions were opened between different Basque nationalist parties and organizations (moderate parties PNV and EA, ELA ${ }^{21}$ and $\mathrm{LAB}^{22}$ unions, Batasuna, cross-border association of municipalities Udalbiltza, abertzale lawyers). Alec Reid, a redemptorist Irish priest who had been involved in the Good Friday Agreement in Northern Ireland (Brewer et al. 2011), worked then as a mediator-broker in the Basque Country. Reid was initially asked by the Elkarri peace organization and by Joseba Segura, a priest from the diocese of Bilbao, to intervene in the Basque Country (Whitfield 2014, pp. 87, 230). Reid engaged in the Basque Country with a wide range of political actors and proposed a tactical ceasefire by ETA in order to reach a proposal of negotiation with the state. He was associated with various meetings and peace conferences held by Elkarri, together with Sant'Egidio, but also in direct intermediation between ETA and the post-2004 Spanish socialist government. ${ }^{23}$

Religious peace mediation, be it performed by local or transnational religious actors, was generally discreet in nature. Confidentiality was the condition for its efficiency. ${ }^{24}$ The most recent sequence around the ceasefire, decommissioning and dissolution of ETA was, on the contrary, signaled by a regular and highly publicized international mediation. The ICG, led by South African lawyer Brian Currin and then by the IVC led by Ram Malikkalingam, held meetings with representatives of the local church. In this case, transnational mediators, through the mediation of the Lokarri peace movement, asked for the presence of representatives of the Church as observers. Moreover, the presence of the Church was complicated by issues of representativeness and the lack of unity of the Church of the Basque Country. The point was highly sensitive, as underlined by the then Vicar General of the Diocese of Bilbao, who participated in the talks as an observer:

When they asked me: did you go there as a representative of the Church? No, I went there on my own, I am a member of the Church, I didn't go there in the name of the Church, but I had permission and support from my bishop. And we went there also because it was discreet. This became known later on, but on that day, there was no press or anything. We stood there, presentation, discussion, and nothing more. We took part in two of these meetings. I could not take part in the third one, I was in Rome. As a tourist, not as a mediator (laughs)! The forehead of social pastoral affairs [of the diocese of Bilbao] went. But, again, only for information. ${ }^{25}$

Representatives of the local clergy also participated as observers in the Aiete conference in October 2011. In this case however, representatives of the Church asked to be present as observers:

We were not on the first list. The list was made up of political parties, unions, some associations from here [the Basque Autonomous Community], from the French Basque Country, from Navarra. But we were not included. Once I was made aware of that, I told Paul [Rios, Lokarri]: we are ready to be there. In the wake of the work done by the church, of what we did in Bilbao. ( . . ) And they invited us. Now, in Aiete, I didn't say anything. I stood there. There was a small issue there: of course, we are the church of Biscaye. I told the bishop: if I have to go to Aiete, you must inform the bishop of San Sebastian. And the bishop of Vitoria as well, even though it is taking place in San Sebastian. The bishop of Vitoria had

21 Eusko Langileen Alkartasuna-Basque Workers Solidarity.

22 Langile Abertzaleen Batzordeak-Patriot Workers Union.

23 T. Whitfield observes that, beyond these direct contacts, some of them through the good offices of the British government, Reid was credited with encouraging the idea of dialogue. However, this mediation also reached its limits: Reid "did not speak Spanish, and his knowledge of the political situation was strongly influenced both by Northern Ireland and what even some within Batasuna would recognize as a degree of wishful thinking about the intentions of ETA" (Whitfield 2014, p. 142). On Reid's role, see also Eguiguren and Aizpeolea (2011, pp. 36, 242) and Alonso (2004, pp. 702-4).

24 In that respect, the publicization by the Spanish Ministry of the Interior of the mediation by Mons. Uriarte, then bishop of Zamora, during the ETA 1998-1999 ceasefire, was interpreted as one of the causes of the failure of the process (Eguiguren and Aizpeolea 2011, p. 35).

25 Vicar General of the Diocese of Bilbao. Author's personal interview. Bilbao, June 2012. Translated from Basque. 
no objection. And we came across the bishop of San Sebastian in the airport, in Paris or somewhere, and we told him that I would be there, since we wanted him to be aware. Then it was released in the press, that I had been there and all the rest ( . . ) well, as an observer. The Vatican also has observers in the UN. But I didn't say anything in Aiete. In informal discussions yes, but not during the conference. No evaluation, no opinion. Of course, there was some kind of official stance, but more from our diocese, from our bishop, not as a representative. They [the bishops] agreed on my presence, but nothing more. There remains, of course, another problem: there is no unified voice at the head of the Basque church. ${ }^{26}$

Inevitably, any presence of representatives of the Basque Church in these arenas raised issues related to the lack of unity of the Basque Church and to its internal divides. ${ }^{27}$ Resorting to transnational religious mediators was a way to avoid this difficulty. By contrast, the presence of international religious leaders among peacemakers was highly publicized during this last sequence of events. On 8 April 2017, many observers were surprised to see, among the figures gathered to witness the disarmament of ETA in Bayonne, Matteo Zuppi, the Archbishop of Bologna and former ecclesial assistant of the Sant'Egidio community, and Harold Good, an Irish Methodist minister who had been involved in the disarmament of the Irish Republican Army (Brewer et al. 2011). The list of locations of ETA's weapons caches was disclosed to these mediators. Their presence, however, was far from unanimously praised by the French and Spanish Basque diocesan authorities, in a further illustration of the internal pluralism of the Basque Church. ${ }^{28}$ The complex nature of the religious institutions made a multilevel presence in peacemaking possible but at the same time aroused tensions within the institutional apparatus of the Church.

\section{Concluding Remarks: Changing Transnational Religious Mediations in a Post-Violent Basque Country}

This article has sought to demonstrate that the involvement of transnational Catholic institutions in peacemaking in the Basque case should not be assessed only through its tangible outcomes. The strategies of Basque actors involved in the process followed symbolic and semantic aims as well as operational ends in terms of intermediation. Involving transnational secular and religious actors was a way for the parties in the conflict to impose their views on peace and on implicit comparisons with other ethnonationalist conflicts that were resolved by transnational mediation. In that respect, this article has distinguished the transnational, indirect, and informal political work conducted by the Basque regional government alongside the hierarchy of the transnational Catholic Church, from the work performed by other Basque political parties and peace movements. In the post-ETA scenario, the end of political violence in the Basque Country also put an end to the role of the Church as a backchannel of communication. Once the "negative peace" had been reached with the end of armed violence, the process entered a new stage consisting in building a "positive peace", dealing with the problems of post-violence, with victims, and with memory and reconciliation (Brewer et al. 2011, p. 40). On these issues, the local church, probably more than its transnational counterpart, would have its say, alongside the secular peace movements, political parties, and civil society organizations.

Nonetheless, the new political scenario did not put an end to relations between the transnational Church and the Basque political, institutional, and social actors. The Basque government, in particular, maintained its old relations with the Holy See but redirected the political work of mediation towards new emergencies, notably the post-2015 displaced persons and refugee crisis. In January 2017, Iñigo Urkullu, President of the Basque government, presented to Mons. Pietro Parolin, State Secretary of

26 Ibid.

27 In a previous work, I proposed to identify at least four positions within the Church of the Basque Country toward the conflict resolution: legalist, soft legalist, alternative, and deliberative (anonymized, chapter 6).

28 M. Malzac, "Le rôle de l'Eglise dans le désarmement de l'ETA", La Croix, 11 April 2018. 
the Holy See, the 2017-2020 Living Together and Human Rights plan (Plan de Convivencia y Derechos Humanos) of the Basque government. The Plan, which resulted from the PNV-PSE governing agreement signed in 2016, no longer gave priority to the end of ETA terrorism but, rather, to the refugee crisis in Europe ${ }^{29}$ By doing so, the government, which had been a pioneer in social policies since its inception, put pressure on the Spanish government to show greater involvement in assistance to refugees. Presenting this plan to the Vatican took on a double meaning. First, it made sense in the traditional paradiplomacy of the Basque government. In substance, the communication channel with the Holy See was facilitated by the social sensitivity of Pope Francis. Urkullu also met Jesuits and Sant'Egidio, two Catholic bodies that had been involved in the peacemaking effort in the Basque conflict and that were now on the frontline of the refugee and migrant crisis. ${ }^{30}$ In August 2019, the lehendakari presented before the Holy See the "Share" proposal, related to refugees and migrants in very vulnerable situations. "Share" was a proposal put forward by various European substate governments ${ }^{31}$ and transmitted to EU authorities. It followed previous initiatives, such as humanitarian corridors, conducted by the Basque government in collaboration with civil society organizations, among them those related to the social branches of the Church. ${ }^{32}$ In a firmly secularized society, such as that of the Basque Country in the 21st century, one emergency was progressively replaced by another, but local and global religious actors kept their mediating role in a pluralistic civil society.

Funding: Part of this research was funded by the Marie Curie Fellowship of the European Commission, which allowed a 24-month stay at the European University Institute in Florence in 2012-2013.

Acknowledgments: The author acknowledges Jeff Haynes for his invitation, Andy Smith and the two anonymous reviewers for their comments and suggestions, all the persons who agreed to be interviewed, Jose María Muñoa for providing access to his personal archive, La Maison de la Traduction and the Editorial office of Religions for the linguistic revision of this article.

Conflicts of Interest: The author declares no conflict of interest.

\section{References}

Abella y Ramallo, Carlos. 2006. Memorias Confesables de un Embajador en el Vaticano. Madrid: Libros Libres.

Aldecoa, Francisco, and Michael Keating. 1999. Paradiplomacy in Action: The Foreign Relations of Subnational Governments. London: Frank Cass Publishers.

Alonso, Rogelio. 2004. Pathways out of terrorism in Northern Ireland and the Basque Country: The Misrepresentation of the Irish model. Terrorism and Political Violence 16: 695-713. [CrossRef]

Appleby, Scott, Robert J. Schreiter, and Gerard F. Powers, eds. 2010. Peacebuilding. Catholic Theology, Ethics, and Praxis. New York: Orbis Books.

Barbato, Mariano. 2013. A State, a Diplomat, and a Transnational Church: The Multi-layered Actorness of the Holy See. Perspectives, Review of International Affairs 21: 27-48.

Bew, John, Martin Frampton, and Iñigo Gurruchaga. 2009. Talking to Terrorists. Making Peace in Northern Ireland and in the Basque Country. London: Hurst \& Company.

Bilbao Alberdi, Galo. 2009. Sacrificadas a los Ídolos. Las Víctimas del Terrorismo en el Discurso de los Obispos Vasconavarros (1968-2006). Bilbao: Instituto Diocesano de Teología y Pastoral, Desclée de Brouwer.

29 Aizpeolea L. R., "Urkullu busca la interlocución con el Vaticano. El Gobierno vasco prioriza en la Santa Sede el reto de los refugiados sobre el final de ETA", El País, 30 January 2017.

30 In December 2018, Sant'Egidio, together with two other bodies working with refugees (Salvamento marítimo Humanitario, Zaporeak-Sabores solidarios) had been awarded the René Cassin Human Rights Prize given by the lehendakari.

31 In August 2019: Basque Autonomous Community, Navarra, Canaries, Navarra, Catalonia, Melilla, the French Basque intermunicipality community, Nouvelle-Aquitaine, Attica.

32 Acnur, Cear-Euskadi, Cruz Roja, Caritas, Servicio Jesuita al Refugiado, etc. (Eusko Jaurlaritza-Gobierno Vasco, "El Lehendakari viajará a Roma para presentar en el Vaticano la Propuesta Share en relación con las personas refugiadas y migrantes en situación de mayor vulnerabilidad", 21 August $2019 . \quad$ https: //www.euskadi.eus/gobierno-vasco/-/noticia/2019/el-lehendakari-viajara-a-roma-para-presentar-en-el-vaticano-lapropuesta-share-en-relacion-con-las-personas-refugiadas-y-migrantes-en-situacion-de-mayor-vulnerabilidad/, Accessed 3 February 2020). 
Bourne, Angela K. 2003. European integration and conflict resolution in the Basque Country, Northern Ireland and Cyprus. Perspectives on European Politics and Society 4: 391-415. [CrossRef]

Brewer, John D., Gareth I. Higgins, and Francis Teeney. 2011. Religion, Civil Society, and Peace in Northern Ireland. Oxford: Oxford University Press.

Cobos Romero, J. 2018. The role of the catholic church and religion in the basque conflict. Paper presented at Religion and Humanitarian Action, Uppsala, Sweden, May 7; Available online: https://www.researchgate.net/ publication/332142748_The_role_of_the_Catholic_Church_and_religion_in_the_Basque_conflict (accessed on 1 February 2020).

De Longcamp, Gonzague. 2019. L’Eglise communauté de mémoire. Nouvelle Revue Théologique 141: 22-35. [CrossRef]

Eguiguren, Jesús, and Luis Rodríguez Aizpeolea. 2011. ETA. Las Claves de la Paz. Madrid: Aguilar.

Espiau Idoiaga, Gorka. 2010. The Peace Process in the Basque Country and in Northern Ireland: A Comparative Approach. ICIP Working Paper 3. Barcelona, Spain: Institut Català Internacional per la pau.

Ferrari, Lisa. 2006. The Vatican as a Transnational Actor. In The Catholic Church and the Nation-State. Comparative Perspectives. Edited by Paul Christopher Manuel, Lawrence C. Reardon and Clyde Wilcox. Washington: Georgetown University Press, pp. 33-45.

Garaikoetxea, Carlos. 2002. Euskadi: La Transición Inacabada. Memorias Políticas. Barcelona: Planeta.

Gilbert, Claude, and Emmanuel Henry. 2012. La définition des problèmes publics: Entre publicité et discrétion. Revue Française de Sociologie 531: 39-55. [CrossRef]

Gilmour, John. 2005. Losing its soul: The changing role of Christian democracy in the development of Spain's new Right. South European Society and Politics 10: 411-31. [CrossRef]

Gusfield, Joseph. 1981. The Culture of Public Problems: Drinking-Driving and the Symbolic Order. Chicago: The University of Chicago Press.

Haynes, Jeff. 2012. Religious Transnational Actors and Soft Power. Surrey: Ashgate.

Hertzke, Allen D. 2016. The Catholic Church and Catholicism in global politics. In Routledge Handbook on Religion and Politics, 2nd ed. Edited by Jeff Haynes. London and New York: Routledge, pp. 36-54.

Hervieu-Léger, Danièle. 1993. La Religion Pour Mémoire. Paris: Cerf.

Hervieu-Léger, Danièle. 2003. Catholicisme, la fin d'un Monde. Paris: Bayard.

Holmsen, Jenny. 2018. Believe It or Not. The New Face of Religion in International Affairs: A Case-Study of Sant'Egidio. Ph.D. thesis, European University Institute, Florence, Italy.

Itçaina, Xabier. 2018. Catholic Mediations in Southern Europe. The Invisible Politics of Religion. London and New York: Routledge.

Iztueta, Paulo. 1981. Sociología del Fenómeno Contestatorio del Clero Vasco: 1940-1975. Donotia: Elkar.

Lecours, André, and Luis Moreno. 2003. Paradiplomacy and stateless nations: A reference to the Basque Country. In The Conditions of Diversity in Multinational Democracies. Edited by Alain G. Gagnon, Montserrat Guibernau and François Rocher. Montreal: The Institute for Research on Public Policy, pp. 267-92.

Leonisio, Rafael, Fernando Molina, and Diego Muro, eds. 2015. ETA Terrorist's Campaigns: From Violence to Politics. London and New York: Routledge.

Madina, Irene, Galo Bilbao, and Angela Bermudez. 2018. Recognizing victims of political violence: Basque literary narratives as an ethical tool. Studies in Conflict and Terrorism, 1-17. [CrossRef]

McCall, Cathal. 2013. European Union cross-border cooperation and conflict amelioration. Space and Polity 17: 197-216. [CrossRef]

Molina, Fernando. 2011. The reign of Christ over the nation: The Basque question in the Spanish Republic, 1931-1936. National Identities 13: 17-33. [CrossRef]

Muro, Diego. 2011. Ethnicity and Violence. The Case of Radical Basque Nationalism. London and New York: Routledge.

Murua, Imanol. 2010. Loiolako hegiak. San Sebastián and Bayonne: Elkar.

Murua, Imanol. 2017. Ending ETA's Armed Campaign. How and Why the Basque Armed Group Abandoned Violence. London and New York: Routledge.

Ontoso, Pedro. 2019. Con la Biblia y la Parabellum: Cuando la Iglesia Vasca Ponía una Vela a Dios y otra al Diablo. Madrid: Peninsula.

Pérez-Agote, Alfonso. 2006. The Social Roots of Basque Nationalism. Reno: University of Nevada Press.

Pérez-Agote, Alfonso. 2012. Les trois logiques de la religion en Espagne. In Catholicisme en Tensions. Edited by Céline Béraud, Frédéric Gugelot and Isabelle Saint-Martin. Paris: Éd. de l'EHESS, pp. 37-49. 
Placer Ugarte, Felix. 1998. Creer en Euskal Herria: La Experiencia Creyente de las Comunidades Cristianas Populares y de la Coordinadora de Sacerdotes de Euskal Herria, 1976-1996. Bilbao: Herria 2000 Eliza.

Serrano Oceja, José Francisco, ed. 2001. La Iglesia Frente al Terrorismo de ETA. Madrid: Biblioteca Autores Cristianos.

Shani, Giorgio. 2016. Transnational religious actors and international relations. In Routledge Handbook on Religion and Politics, 2nd ed. Edited by Jeff Haynes. London and New York: Routledge, pp. 299-313.

Smith, Andy. 2016. The Politics of Economic Activity. Oxford: Oxford University Press.

Tellidis, Ioannis. 2018. Peacebuilding beyond terrorism? Revisiting the narratives of the Basque conflict. Studies in Conflict and Terrorism, 1-19. [CrossRef]

Totoricagüena, Gloria. 2005. Diasporas as non-central governmental actors in foreign policy: The trajectory of Basque paradiplomacy. Nationalism and Ethnic Politics 11: 265-87. [CrossRef]

Troy, Jodok. 2018. The Pope's own hand oustretched: Holy See diplomacy as a hybrid mode of diplomatic agency. The British Journal of Politics and International Relations 20: 521-39. [CrossRef] [PubMed]

Wehr, Paul, and John Paul Lederach. 1991. Mediating conflict in Central America. Journal of Peace Research 28: 85-98. [CrossRef]

Whitfield, Teresa. 2014. Endgame for ETA. Elusive Peace in the Basque Country. New York: Oxford University Press.

Zulaika, Joseba, and Iñaki Murua. 2017. How terrorism ends-And does not end: The Basque case. Critical Studies on Terrorism 2: 338-56. [CrossRef]

(C) 2020 by the author. Licensee MDPI, Basel, Switzerland. This article is an open access article distributed under the terms and conditions of the Creative Commons Attribution (CC BY) license (http://creativecommons.org/licenses/by/4.0/). 



\title{
Article \\ International Religious Freedom Promotion and US Foreign Policy
}

\author{
Lee Marsden \\ School of Politics, Philosophy, Language and Communication Studies, University of East Anglia, \\ Norfolk NR4 7TJ, UK; l.marsden@uea.ac.uk
}

Received: 6 April 2020; Accepted: 15 May 2020; Published: 21 May 2020

\begin{abstract}
The freedom to practice one's religious belief is a fundamental human right and yet, for millions of people around the world, this right is denied. Yearly reports produced by the US State Department, United States Commission on International Religious Freedom, Open Doors International, Aid to the Church in Need and Release International reveal a disturbing picture of increased religious persecution across much of the world conducted at individual, community and state level conducted by secular, religious, terrorist and state actors. While religious actors both contribute to persecution of those of other faiths and beliefs and are involved in peace and reconciliation initiatives, the acceptance of the freedom to practice one's faith, to disseminate that faith and to change one's faith and belief is fundamental to considerations of the intersection of peace, politics and religion. In this article, I examine the political background of the United States' promotion of international religious freedom, and current progress on advancing this under the Trump administration. International Religious Freedom (IRF) is contentious, and seen by many as the advancement of US national interests by other means. This article argues that through an examination of the accomplishments and various critiques of the IRF programme it is possible, and desirable, to discover what works, and where further progress needs to be made, in order to enable people around the world to enjoy freedom of thought, conscience and religion.
\end{abstract}

Keywords: international religious freedom; persecution; US foreign policy

Zumrat Dawut, a Uighur Muslim, was interned along with one million others in Chinese internment camps in Xinjiang between April and June 2017. While there, she was beaten by guards and given unknown/drugs resulting in dizziness and disorientation. Once released, she was forced to renounce her faith officially, raise the Chinese flag each day and live with government-assigned 'Han' Chinese minders. She was eventually able to flee the country, arriving in the United States with her husband and family in April 2019. Zumrat's story is not unusual, either in China or much of the rest of the world. Zumrat was one of eleven survivors of religious persecution who addressed the United Nations General Assembly in September 2019 on the importance of religious freedom. ${ }^{1}$ While Zumrat's suffering was at the lower end of the persecution spectrum, it nonetheless highlights an increasing imperative for governments around the world to tackle the issue of religious persecution and encourage religious freedom.

The United States has been at the forefront of promoting religious freedom internationally over the past two decades, with varying degrees of success and commitment to the task. With a Vice President, Secretary of State and Ambassador-at-Large for International Religious Freedom (IRF), who are committed Christians and believers in international religious freedom, the policy takes on

1 Survivors of Religious Persecution at the 74th Session of the UN General Assembly, 22 September 2019. https://www.state. gov/survivors-of-religious-persecution-at-unga/ Accessed 1 April 2020. 
a renewed salience, which this article seeks to interrogate. The promotion of international religious freedom has proved extremely contentious, and is seen by many as a means of promoting US foreign policy interests by other means. While US foreign policy interests are not unimportant, this article seeks to explore the efficacy of IRF as a means of enhancing religious liberty beyond America's shores. The research was conducted by analysing the policy speeches, statements, remarks, press conferences and writings of the key practitioners in successive administrations, and through the examination of policy documents and legislation as primary source data, while reviewing the extensive literature of critiques of IRF policy. The paper first examines the political background and outworking of IRF policy in the 21st Century, before, secondly, considering IRF as a US foreign policy instrument under successive administrations to the present day. Third, two critiques of IRF policy are explored from the position of those arguing from the viewpoint of IRF advocacy that IRF is ineffective, and those from secularist arguments that it is undesirable. Fourth, the record of IRF and the critiques are used to evaluate the efficacy of IRF promotion arguing, in conclusion, that through an examination of the accomplishments and various critiques of the IRF programme, it is possible, and desirable, to discover what works and where further progress needs to be made, in order to enable people around the world to enjoy freedom of thought, conscience and religion.

\section{International Religious Freedom the Background}

IRF is contentious and contested within the academy, and more importantly within diplomatic communities and the countries they interact with or represent. Contestation involves debate about the extent of religious persecution in countries and, if such persecution exists, what, if anything, should other governments do about it? Further, should this 'anything' include protecting and promoting religious freedom as a universal right? IRF is contested on realist grounds of non-interference in the domestic affairs of sovereign states, and whether what might loosely be regarded as US, or at best Western values, being universalised and imposed on other countries without consideration of the national context, history and cultural background is desirable. Such considerations, though sincerely held, go against a long tradition in the international community of supporting religious freedom as one among many human rights.

The United Nations General Assembly met in Paris in December 1948 to seek to build a new international order, where human rights were to be upheld. Article 18 of The Universal Declaration of Human Rights (UDHR) adopted at the assembly stated:

Everyone has the right to freedom of thought, conscience and religion; this right includes freedom to change his religion or belief, and freedom, either alone or in community with others and in public or private, to manifest his religion or belief in teaching, practice, worship and observance. ${ }^{2}$

The International Covenant on Civil and Political Rights (ICCPR) introduced in 1966 and enacted since 1976 has been ratified by 173 countries and expands on the UDHR:

\section{Article 18}

1. Everyone shall have the right to freedom of thought, conscience and religion. This right shall include freedom to have or to adopt a religion or belief of his choice, and freedom, either individually or in community with others and in public or private, to manifest his religion or belief in worship, observance, practice and teaching.

2. No one shall be subject to coercion which would impair his freedom to have or to adopt a religion or belief of his choice.

2 Universal Declaration of Human Rights. Available at https://www.un.org/en/universal-declaration-human-rights/ Accessed 2 April 2020. 
3. Freedom to manifest one's religion or beliefs may be subject only to such limitations as are prescribed by law and are necessary to protect public safety, order, health, or morals or the fundamental rights and freedoms of others.

4. The States Parties to the present Covenant undertake to have respect for the liberty of parents and, when applicable, legal guardians to ensure the religious and moral education of their children in conformity with their own convictions.

\section{Article 27}

In those States in which ethnic, religious or linguistic minorities exist, persons belonging to such minorities shall not be denied the right, in community with the other members of their group, to enjoy their own culture, to profess and practise their own religion, or to use their own language. ${ }^{3}$

The covenant has been ratified by many countries, with well documented human rights abuses including North Korea and signed, though not ratified, by China. In 1981 concerned at the continuing discrimination and persecution of religion a Declaration on the Elimination of All Forms of Intolerance and of Discrimination Based on Religion or Belief reemphasised the UN's commitment, along with its 182 signatory nations, to protecting the freedom for people to practice their faith individually and in community. The Declaration further emphasised the emancipatory value and role for religion in the aims and objectives of the United Nations:

Convinced that freedom of religion and belief should also contribute to the attainment of the goals of world peace, social justice and friendship among peoples and to the elimination of ideologies or practices of colonialism and racial discrimination. ${ }^{4}$

The enthusiasm for incorporating IRF as an important aspect of US foreign policy has its origins in a growing awareness and concern by initially Christian advocacy groups, and prominent evangelicals of the persecution of Christians around the world in the immediate post-Cold War era. The 'suffering or persecuted church' had been an area of particular concern behind the iron curtain, spearheaded by the work of tortured Romanian pastor Richard Wurmbrand and God's Smuggler Brother Andrew's Open Doors organisation during the Cold War, and attracted much support among American evangelicals (Wurmbrand 2004; Andrew 2015). Amongst this group there was an increasing concern about the continued persecution of Christians in the remaining communist countries, including Vietnam, North Korea and China, and in a number of Muslim-majority countries (Bettiza 2019, pp. 57-58).

Bettiza identifies a coalition emerging about the plight of Southern Sudanese Christians in Sudan's civil war (1983-2005). The group consisted of evangelicals identified with the Christian Right, such as Richard Land (president of the Southern Baptist's Ethics \& Religious Liberty Commission), Pat Robertson (Christian Coalition), James Dobson (Family Research Council) and Beverly LaHaye (Concerned Women of America). The National Association of Evangelicals released a Statement of Conscience Concerning Worldwide Religious Persecution in 1996, highlighting the importance of the issue. These were joined by anti-persecution and missionary organisations including Voice of the Martyrs, Open Doors, Christian Solidarity International, International Christian Concern and Christian Freedom International. The final part of this coalition were those Christian and Jewish policy analysts in conservative think tanks, including Paul Marshall and Nina Shea at Freedom House and Michael Horowitz at the Hudson Institute (Bettiza 2019, pp. 57-60; Marshall and Gilbert 1997; Marshall and Shea 2011; Marshall et al. 2013).

3 International Covenant on Civil and Political Rights. Available at https://www.ohchr.org/EN/ProfessionalInterest/Pages/ CCPR.aspx Accessed 2 April 2020.

4 Declaration on the Elimination of All Forms of Intolerance and of Discrimination Based on Religion or Belief. Available at https://www.ohchr.org/EN/ProfessionalInterest/Pages/ReligionOrBelief.aspx Accessed 3 April 2020. 
The coalition coalesced around support for Congressman Frank Wolf (R-Virginia) and Senator Arlen Specter's (R-Pennsylvania) IRFA. ${ }^{5}$ Wolf's original concern had been largely for persecuted Christians, with limited appeal across both houses of Congress, by expanding an anti-persecution rhetoric into a positive affirmation and promotion of religious freedom internationally, the coalition was able to draw in those other faiths or those concerned about them (Bettiza 2019, p. 60; Castelli 2007; Hertzke 2004; Jewish Telegraph Agency 1998). The IRFA brought international religious liberty to the attention of the US foreign policy community, creating the Office for International Religious Freedom (OIRF) in the US State Department, and the position of Ambassador-at-Large for International Religious Freedom. The Ambassador-at-Large would be a key driver of IRF policy, working closely with the Secretary of State, and being the main conduit for information on IRF to the President. ${ }^{6}$ The Act requires the President to designate those nations which commit 'systematic, ongoing, and egregious violations of religious freedom' as 'countries of particular concern' (CPCs), and for the State department to produce an annual report on the state of religious freedom in all the countries of the world. In addition, it created the United States Commission on International Religious Freedom (USCIRF), an independent and bipartisan federal government commission made up of five appointees from the President's party, and four from the opposition (three presidential appointments-one selected by the leaders of the House and Senate of the President's party, and two each from the leaders of the House and Senate from the non-presidential party.

Each year, USCIRF produces an annual report on the state of IRF and provides policy recommendations to the US government, in accordance with IRFA. The Act requires the President, who has delegated this function to the Secretary of State, to designate as "countries of particular concern" (CPCs) those nations that qualify as the world's most severe religious freedom violators. The Commission recommends countries that, in its view, meet the CPC threshold (Leo and Argue 2012, p. 67). Under the IRFA both the State Department and USCIRF submit reports annually on international religious freedom. The USCIRF differs from State's by only reporting on selected countries it has particular concerns over. USCIRF's report discuss conditions in those countries, analyses US policy toward them and make policy recommendations. These reports hold the executive branch to account over their implementation of IRFA (USCIRF 2016).

As an indication of the continued traction of IRF as a foreign policy concern, the legislative branch has added two further pieces of legislation: The Near East and South Central Asia Religious Freedom Act of 2014 with a Special Advisor for Religious Minorities in this region, and at the very end of the Obama administration, in December 2016, the Frank R. Wolf International Religious Freedom Act, which strengthened the 1998 act by mandating the US executive to introduce a Special Watch List for those countries not yet deemed as bad as the designated CPCs. The Frank Wolf Act further introduced "Entities of Particular Concern" and "Designated Persons List" for non-state actors abusing religious freedom. The State Department was also obliged to develop an online training course on IRF for all foreign service officers. ${ }^{7}$

\section{International Religious Freedom as a US Foreign Policy Instrument}

The IRF advocacy coalition has developed and grown in confidence since the early campaigns around the IRFA. While it is undeniable that leading supporters of mainstreaming IRF as a US foreign policy strategy are overwhelmingly Christian, they have developed a broad-based coalition across political and religious divides to strongly advocate for IRF as an indispensable component of human

5 Freedom from Religious Persecution Act of 1997-Establishes in the Executive Office of the President the Office of Religious Persecution Monitoring. Available at https://www.congress.gov/bill/105th-congress/house-bill/2431/summary/00 accessed 1 May 2020

6 H.R. 2431. International Religious Freedom Act of 1998. Available at https://www.senate.gov/legislative/LIS/roll_call_lists/ roll_call_vote_cfm.cfm?congress $=105 \&$ session $=2 \&$ vote $=00310$ accessed 1 May 2020 .

7 Frank R. Wolf International Religious Freedom Act 2016. Available at https://www.congress.gov/bill/114th-congress/housebill/1150 Accessed 1 May 2020. 
flourishing. The USCIRF has included Muslims, Jews, a Hindu, alongside evangelicals, mainline Protestants and Catholics among its commissioners. The five Ambassadors-at-Large to date have included a Jewish rabbi. For Thomas Farr, who served as the first director of the OIRF and founded the Religious Freedom Institute in 2016, religious freedom has emancipatory potential and is an essential component of stable self-government because it:

... protects the rights of individuals and groups to act publicly in ways consistent with belief. This positive understanding of religious freedom implicates justice for individuals and communities, and the long-term stability of the democratic state. It includes, most importantly, the right to influence public policy within limits roughly similar to those that apply to other individuals and associations in civil society. (Farr 2008, p. 18)

Chris Seiple, of the Institute for Global Engagement (IGE), considers that it is a function of the 'innate dignity' of humans to 'possess the inherent freedom to believe in whatever they want, religious or otherwise, as well as practice and share those beliefs in private and public settings'. As such ... 'religious freedom is the legally-protected and culturally-accepted opportunity to choose, change, share, or reject beliefs of any kind, including religious ones, and to bring those beliefs to public discussions' (Seiple 2012, p. 98). This is interpreted as a universal value, which he argues, with fellow IGE member Dennis Hoover, is necessary for sustainable security, and which Allen Hertzke claims is essential for societies to flourish peacefully (Seiple and Hoover 2012; Hertzke 2012, p. 4).

The linkage of religious freedom and human flourishing is echoed by Brian Grim, formerly of Pew Forum, and author of numerous reports tracking religious harassment and discrimination around the world, before establishing the Religious Freedom and Business Foundation. Grim is one of a number of scholars, including Roger Finks, Daniel Philpott and Alfred Stepan, linking religious freedom to economic prosperity, stable societies and the promotion of other human rights as necessary components for healthy democracies, and therefore an essential component of US foreign policy, to bring about a more prosperous and pacific international order (see (Grim 2008; Grim and Finke 2010; Grim et al. 2014; Philpott and Shah 2016; Stepan 2000).

As the currency of democracy promotion as a US foreign policy strategy has devalued, following the policy failures in Iraq and Afghanistan, so increasingly IRF is presented by its proponents as a necessary tool in the United States' diplomatic box. IRF is presented as national security issue in the same way democracy promotion has been, and attracting similar criticism of universalising American values. Where countries are not persecuting domestic minorities and are accepting of those of other beliefs or no beliefs, then, the argument goes, they are more likely to live peaceably with other countries, and to increase the wellbeing of their own citizens (Chicago Council on Global Affairs 2010; Inboden 2012; Farr 2014). Promoting IRF, it is argued, helps to diffuse the suspicion of religion as a potential cause of conflict and disempowers radical religionists:

Real or imagined security threats emanating from religion inspire overzealous repression of religion, which ironically creates the conditions that genuine religious radicals are seeking: an atmosphere in which the radicals are the only opposition to the state, which builds sympathy for them among those who would otherwise be religious moderates, therefore decreasing the legitimacy of the state. (Seiple and Hoover 2012, p. 321)

Although the IRFA became law in 1998, it was slow to gain traction. Neither the Clinton or Bush administrations accorded the IRFA high priority, US foreign policy misadventures in Afghanistan and Iraq identified the Bush administration as intervening militarily in Muslim majority countries and showing little regard for interfaith dialogue. While the USCIRF continued to highlight religious freedom abuses around the world, and officials within the OIRF worked diligently to try and raise the profile of IRF, it was not until the Obama administration that IRF began to gain momentum as a US foreign policy instrument. Obama's Cairo speech was intended to kickstart a new relationship with the Muslim majority world and engage in interfaith dialogue, in distinction to his predecessor's 
more unilateralist approach. ${ }^{8}$ In February 2010, the Interagency Working Group on Religion \& Global Affairs brought together federal agencies to enhance religious engagement and establish a Religion and Foreign Policy Working Group. Religious education training was developed for foreign service operatives and according to Judd Birdsall, a practitioner serving in the IRF Office it became 'integrated and respected in ways that were unimaginable in previous administrations' (Birdsall 2012, p. 37). The OIRF worked with other State Department offices, the White House and US Embassies, in organising inter-faith conferences, in the belief that dialogue and diplomacy could advance the cause of religious freedom more than the blunt instrument of sanctions. Diplomatic efforts by the OIRC working with the Organisation of Islamic Cooperation (OIC) and building alliances managed to overturn the OIC's resolution on Defamation of Religions, which had received majority UN General Assembly backing, seeking to protect and extend blasphemy laws (Birdsall 2012, p. 37). The OIRF received a significant boost when Rabbi David Saperstein was appointed Ambassador-at-Large in January 2015. Saperstein already enjoyed a significant reputation for interfaith dialogue and as lobbyist on Capitol Hill. Saperstein worked closely with the Canadians to develop an intergovernmental contact group bringing together like-minded governments eager to promote religious freedom. Although the annual IRF report and the USCIRF reports provided ample opportunity to castigate countries of particular concern, Saperstein's style, which enjoyed bipartisan support, was to travel extensively visiting 25 countries to build alliances and win support for religious freedom. He raised concerns with Saudi Arabia, Egypt, Pakistan, Sudan, Burma, Iraq and Nigeria about blasphemy and apostasy laws and laws pertaining to the defamation of religion. ${ }^{9}$ Saperstein used diplomacy to persuade governments to make incremental changes to their approaches to IRF, and set piece events, such as the launch of the annual IRF Report, to challenge serial offenders, including Iran, for its treatment of Sunnis, Bahais, Christian converts, Sufis, Yarsanis and Zoroastrians; Vietnam, Burma, Russia, China and Tajikistan. Working closely with Secretary of State John Kerry, the OIRF was better resourced and able to pursue diplomacy in advancing the IRF agenda.

And since my appointment, we have been given significant increases in staff and resources, allowing us to expand our country monitoring work, to increase our visits to country where our religious freedom advocacy can make a constructive difference, and to increase our already robust programmatic work internationally. ${ }^{10}$

Following the 2016 election, the work of the OIRF continued, but waited twelve months to appoint a successor to Saperstein as Ambassador-at-Large. Sam Brownback, an early and enthusiastic supporter of the IRFA and a Catholic, had represented Kansas in the House, Senate and as governor. Democrats resisted his nomination because of his record on LGBT and pro-life issues, and his nomination was secured only with the casting vote of Vice President Mike Pence in the Senate vote. The appointment of Mike Pompeo as Secretary of State in April 2018 added renewed zeal for the promotion of IRF as a foreign policy strategy, in pursuit of US national interests. On 24-26 July 2018, just three months after being sworn in as Secretary of State, Pompeo and Sam Brownback organised and hosted an inaugural Ministerial to Advance Religious Freedom in Washington, DC. The event brought together around 350 faith ministers and activists representing 80 nations to discuss ways to advance IRF. The Secretary of State opened the event, setting out the priority accorded religious freedom in the Trump administration:

8 Barack Obama speech 'On a New Beginning' at Cairo University, Cairo, Egypt. 4 June 2009. Available at https: //obamawhitehouse.archives.gov/the-press-office/remarks-president-cairo-university-6-04-09 accessed 2 May 2020.

9 David N. Saperstein. Remarks at the Release of the 2014 Report on International Religious Freedom. Washington, DC. 14 October 2015. Available at https://20092017.state.gov/r/pa/prs/ps/2015/10/248201.htm accessed 2 May 2020.International Religious Freedom Report and Briefing on the Release of the 2015 Annual Report on International Freedom (IRF). Available at https://2009-2017.state.gov/documents/organization/238390.pdf 2014, accessed 2 May2020 and International Religious Freedom Report for 2015. Available at https://2009-2017.state.gov/j/drl/rls/irf/religiousfreedom//index.htm, accessed 3 May 2020.

10 David N. Saperstein. Briefing on the Release of the 2015 Annual Report on International Freedom (IRF). Washington, DC. 10 August 2016. Available at https://20092017.state.gov/r/pa/prs/ps/2016/08/260962.htm accessed 4 May 2020. 
The Trump administration recognizes that religious freedom is a fundamental American liberty, and this has been clear from the administration's earliest days and indeed the earliest days of our nation.

The United States advances religious freedom in our foreign policy because it is not exclusively an American right. It is a God-given universal right bestowed on all of mankind. Seventy years ago, the Universal Declaration of Human Rights affirmed this when 48 nations declared that "everyone has the right to freedom of thought, conscience, and religion."11

Vice President Pence brought greetings to the Ministerial from the President, and assured delegates that 'religious freedom is a top priority of this administration' ... 'We do this because it is right. But we also do this because religious freedom is in the interest of the peace and security of the world' ${ }^{12}$ The Vice President used his speech to castigate China for its treatment of the Uighur and Tibetan Buddhists, Russia for its treatment of Jehovah's Witnesses, Iran for persecution of Sunni Muslims, Christians, Jews and Bahai, the Nicaraguan government of Daniel Ortega for attacks on the Catholic Church, ISIS abuses of the Yazidis and Turkey for its incarnation of pastor Andrew Brunson. He also announced the establishment of a Genocide Recovery and Persecution Response Program. The most significant outcome of the Ministerial, however, was the launch of the Potomac Declaration.

The Potomac Declaration builds on Article 18 of the UDHR celebrating religious freedom as a universal, God-given right. It affirms the reality of widespread persecution based on religion, and the obligation of all countries to promote religious freedom to contribute towards international peace and human flourishing. There should be no discrimination or coercion in religion to force religious observance or conformity. Individuals should be free to worship, or not, as they chose, and free to exercise their conscience in all things. Further, the Declaration affirms that religious freedom is an individual, rather than a collective right:

Religious freedom applies to all individuals as right-holders. Believers can exercise this right alone or in community with others, and in public or private. While religions do not have human rights themselves, religious communities and their institutions benefit through the human rights enjoyed by their individual members. (OIRF 2018a)

The Declaration was followed by a plan of action for countries around the world to put into practice to promote religious freedom. Sixty-five policy recommendations were divided into seven subsections, including: Defending the Human Right of Freedom of Religion or Belief; Confronting Legal Limitations; Advocating for Equal Rights and Protections for All, Including Members of Religious Minorities; Responding to Genocide and other Mass Atrocities; Preserving Cultural Heritage; Promoting and Protecting Religious Freedom and Tolerance in Schools; Protecting persecuted minorities in conflict and crisis settings; and Strengthening the Response, which calls for greater attention and resourcing in pursuance of religious freedom (OIRF 2018b).

The 2018 Ministerial enabled IRF to gather further momentum, and the following year a second one took place again in Washington DC in July. On this occasion, the first time a Secretary of State has held back-to-back ministerials on the same human rights issue, over one thousand civil society and religious leaders from one hundred countries attended. In his opening address, Pompeo described the countries represented as different, but having the same objective in advancing religious freedom, and to reaffirm the principle that: 'All people from every place on the globe must be permitted to practice their faith openly - in their homes, in their places of worship, in the public square-and believe what

11 Michael R. Pompeo, Remarks at the Ministerial to Advance Religious Freedom, Washington DC, 26 July 2018. Available at https://www.state.gov/remarks-at-the-ministerial-to-advance-religious-freedom/ accessed 1 April 2020.

12 Michael Pence. Remarks at Ministerial to Advance Religious Freedom, Washington DC, 26 July 2018. available at https:// www.whitehouse.gov/briefings-statements/remarks-vice-president-pence-ministerial-advance-religious-freedom/ accessed 2 April 2020. 
they want to believe' ${ }^{13}$ The delegates renewed their commitment to actively promote IRF around the globe. Rather than positioning the advancement of religious freedom as a uniquely US responsibility or passion, religious freedom must become normative in national and international politics. Poland took responsibility to host a third Ministerial to Advance Religious Freedom in Warsaw July 2020.

In their first two years at the State Department, Mike Pompeo and Ambassador Brownback have been relentless in pursuing and expanding the reach of IRF in terms of raising its profile and bringing together like-minded countries in support. In June 2019, the Secretary of State announced the establishment of a Commission on Unalienable Rights, to advise on the promotion of individual freedom, equality and democracy through US foreign policy, linking this to the principle of religious freedom and an appeal to the Declaration of Independence and natural law (Pompeo 2019; Risse 2020, p. 13). The status of the OIRF has been increased, with additional staffing resources for OIRF, and the Ambassador-at-Large Sam Brownback continues to report directly to the Secretary of State. ${ }^{14}$ Brownback has visited numerous countries during his tenure, pursuing diplomacy to seek to bring about internal change on IRF. He has used set piece speeches to bring international attention to the plight of the Rohingya and Uighur Muslims; the treatment of Buddhists by the Chinese authorities in Tibet; and human rights and religious freedom abuses in Eritrea, Iran, Myanmar, North Korea, Pakistan, Sudan, Saudi Arabia, Tajikistan and Turkmenistan. ${ }^{15}$ Brownback has also used Twitter, speeches and remarks to call for the release of Bahai hostages held by the Houthi in Yemen, and to denounce Boko Haram and Fulani herdsmen for their targeted persecution of Christians in Nigeria. The ill treatment of religious minorities in Bahrain, Afghanistan, Uzbekistan, Kazakhstan, Cuba., Haiti, Russia's Jehovah's Witnesses, Nicaragua and North Korea has also been emphasised. Rather than the United States being a lone voice, diplomatic efforts have brought together a growing number of countries around the world seeking to advance religious freedom. Over the course of the Obama and Trump administrations, IRF policy has become increasingly multilateral and international.

The international momentum for religious freedom has developed with Poland leading a UN initiative to declare an annual International Day Commemorating the Victims of Violence Based on Religion or Belief on 22 August. An event on religious freedom at the United Nations in September 2019 was addressed by President Trump, Vice President Pence and Secretary of State Pompeo. Trump chaired meetings and publicly chastised Iran, Iraq, China, Venezuela and Nicaragua for religious freedom rights abuses. ${ }^{16}$ In February 2020, Pompeo and Brownback were able to announce the formation of a 27 nation International Religious Freedom Alliance, committed to advancing the cause of IRF, and based on existing international legislation on human rights and the emphasis on religious belief that critics have found so problematic.

The Alliance intends to advocate for freedom of religion or belief for all, which includes the right of individuals to hold any belief or none, to change religion or belief and to manifest religion or belief, either alone or in community with others, in worship, observance, practice and teaching. (OIRF 2020)

13 Michael R. Pompeo. Remarks at the Ministerial to Advance Religious Freedom, Washington, DC 16 July. Available at https://www.state.gov/secretary-of-state-michael-r-pompeo-at-the-ministerial-to-advance-religious-freedom/ accessed 2 April 2020.

14 Michael R. Pompeo. Remarks at the Release of the 2018 Annual Report on International Religious Freedom Washington, DC, 21 June 2019 available at https://www.state.gov/secretary-of-state-michael-r-pompeo-at-the-release-of-the-2018-annualreport-on-international-religious-freedom/ accessed 2 April 2020.

15 Samuel D. Brownback, Special Briefing on International Religious Freedom Report 2018. Washington, D.C. 21 November 2019. Available at https://www.state.gov/ambassador-at-large-for-international-religious-freedom-samuel-brownback/ accessed 2 May 2020.

16 Donald J. Trump. Remarks at the United Nations Event on Religious Freedom. United Nations Headquarters, New York, NY 23 September 2019. Available at https://www.whitehouse.gov/briefings-statements/remarks-president-trump-unitednations-event-religious-freedom-new-york-ny/ accessed 1 April 2020. 


\section{Critique 1-Ineffectiveness of IRF}

Having set out the case for promoting IRF, I now turn to consider criticisms of successive administrations' lack of willingness to invest in and pursue IRF as a priority for US foreign policy. Writing towards the end of the George W. Bush administration, Thomas Farr lamented that the commitment to IRF by the Bush and previous Clinton administration was 'sporadic in its application and minimal in its effects' (Farr 2008). Four years later, commenting on the Obama administration, he lamented that it was difficult to find any significant progress (Farr 2012a). This has remained an ongoing problem. Successive presidents and secretaries of state, including Madeleine Albright, Colin Powell, Condoleezza Rice, Hilary Clinton, John Kerry and Rex Tillerson have all proclaimed the importance of IRF and yet the foreign policy apart from a few prisoner releases have very little to show for their efforts.

A recurring criticism of the implementation of policy concerns the unwillingness of those charged with the responsibility to actively promote IRF because of a secularist approach adopted by foreign service practitioners, where religion is considered a private matter and the first amendment misinterpreted as precluding governmental involvement in promoting religious freedom (Farr 2008, 2012a, 2012b, 2013; Seiple and Hoover 2012; Seiple 2012). While efforts have been made to train foreign service officers, such training has been voluntary and insufficient to change a secularist mindset (Farr 2013; Mandaville and Silvestri 2015). There also remains a lack of clarity among foreign policy practitioners between religious tolerance and religious freedom (Rieffer-Flanagan 2019). The OIRF sits within the Bureau of Civilian Security, Democracy, and Human Rights, alongside eight other offices and bureaux and reports to the Under Secretary, rather than directly to the Secretary, signalling that IRF is but one of a number of competing interests within the Department of State, and not a high priority. This is a perception encouraged by the lackadaisical approach in appointing Ambassadors-at-Large for International Religious Freedom, mandated under the IRFA. Barack Obama took over two years to appoint Suzan Johnson Cook, in April 2011, who resigned from the position in October 2013, and a further fourteen months to appoint her successor, David Saperstein. The Trump administration left the position vacant until the appointment of Sam Brownback, an early supporter of the IRFA, in February 2018.

Alongside the relatively low status accorded the office, successive administrations have failed to consider religious freedom strategically in relation to actions in Iraq and Afghanistan, and to emphasise its importance during the Arab Spring. In countries where the US has invested considerable resources, including Afghanistan, Iraq, Egypt and Pakistan, religious freedom has diminished rather than improved (Farr 2012b). Obama failed to capitalise on his Cairo speech to the Muslim majority world by involving religious freedom in subsequent policy actions in the region, or indeed to include IRF in the 2009 National Security Strategy (Farr 2012a). The rhetoric of IRF has been proclaimed, but this has not translated into action on the ground. The OIRF produces comprehensive reports highlighting abuses of religious freedom and the USCIRF detailed reports on countries of particular concern annually, but countries are not held to account or sanctioned for their behaviour on religious rights, even where these are extreme including imprisonments, torture, judicial killings and destroying places of worship. In over two decades, only Ethiopia has been sanctioned by the United States for abuses of religious freedom (Farr 2013). Presidents are able to waive sanctions in what they consider to be the national interest, usually where there is a strategic or economic interest involved, such as Saudi Arabia or China.

This is not to say that successive administrations have been indifferent to IRF, the recognition of its importance as an innate human right, the development of an IRF infrastructure through the development of the OIRF and USCIRF, the regular reporting to Congress, and training for foreign service officers, all point to a willingness to promote IRF and protect the rights of people, in accordance with Article 18 of the UNDHR. Promoting religious freedom is hard domestically, but even more so internationally, where motives are impugned, foreign service officers are sceptical and governments are unwilling to be held to account by another country pursuing its own national interests. While advocates 
of IRF are conscious of the failings of successive administrations in fulfilling the spirit of the IRFA, the appropriateness of promoting and protecting international religious freedom is strongly contested.

\section{Critique 2: Secularist Objections}

The construction of IRF as a conceptual framework is problematised by critiques of the trend towards mainstreaming IRF in international politics and US foreign policy in particular. Rather than being an outworking of the UDHR Article 18, as advocates claim, Elizabeth Shakman Hurd portrays IRF as a means of control, 'a modern technique of governance, authorizing particular forms of politics and regulating the spaces in which people live out their religion in specific ways' (Hurd 2015, p. 38). Religious freedom advocacy is presented as historically specific and divisive in affording legitimacy to certain forms of religion and not others. Critical approaches to IRF situate religious freedom advocacy as a 'regime', with a Western-centric understanding of religion, which privileges belief as the main designator of what constitutes religion, and which seeks to prescribe what is meant by belief and unbelief (Bettiza 2019; Castelli 2010; Hurd 2015).

Essentialising or privileging religion as a distinct category restricts the appreciation of identity as anything other than a religious one, when identity is inherently multifaceted and multidimensional. If individuals or communities do not neatly fit into such a categorisation of religion, they risk marginalisation or neglect. When religion is the 'official marker of difference', a fixed religious identity eclipses 'other modes of belonging' (Hurd 2015, p. 42). In the religious advocacy regime, all issues and events are problematised as religious, rather than recognising the complexities of all situations in historical, social, economic, political and geographic context (Bettiza 2019; Hurd 2015; Sullivan 2005; Mahmood 2015; McAlister 2019). For Bettiza:

... the regime actively contributes to religionizing world politics through mechanisms of categorization. Its institutions, discourses, and practices regularly (re)present and (re)produce a world dominated by religious categories and realities. (Bettiza 2019, p. 92)

In so doing, the regime is able to deflect 'attention away from caste, class, colonial history, economic justice land rights, and other factors' (Hurd 2015, p. 42).

If people are forced into religious categories, what is to become of those who identify with more than one category, or identify with a non-traditional, unprotected group or with no religion at all? When religion is the main determinant of identity, who gets to speak for a particular religious group? When people are categorised by religious belief, then they are incentivised to frame demands or requests for asylum in the language of religious rights, thereby further strengthening the religious freedom advocacy regime's framing schema (Hurd 2013, 2015, pp. 37-64). This contributes to a desecularising trend in international politics, which secularists consider harmful and particularist, in the sense that it universalises an American or Western interpretation of religion, overlooking other causal explanations for events in international politics, and opens up space for all aspects of international politics to be religionised (Bettiza 2019, p. 95).

Further criticism of religious freedom advocacy centres on a perceived Christian bias in the IRF agenda, particularly in terms of its incorporation within US foreign policy strategy. The demand for IRF as a foreign policy strategy, and as the impetus for IRFA, is traceable to concerns about the persecution of Christians in the post-Cold War environment. The identification of specific areas of concern as the remaining communist countries (Vietnam, North Korea, China and Cuba), and Muslim majority countries dovetailed with countries where the United States has ongoing concerns, leading to accusations that a focus on the persecution of Christians was overplayed and co-opted, in order to pursue other US foreign policy goals (Castelli 2007; Hertzke and Shah 2016; Hurd 2015, pp. ix-xii; McAlister 2018, 2019; Moss 2013). The dominance of Christian actors in promoting IRF as activists, advocates, practitioners and drivers of policy in Congress, the OIRF, and the executive is a cause for concern from secularists seeking to re-establish the privatisation of religion, recontextualise understandings of religion away from a focus on belief to one which includes practice, community and 
the ethereal, and to prevent an exclusivist conceptualisation of Christian suffering overshadowing that experienced by other faiths, beliefs and none.

The problem with this argument is that it does not fully account for the prevalence of religious discrimination faced by others, and it promotes a sense of unique victimization in a context in which a broad variety of religious and ethnic groups are under threat. (McAlister 2019, p. 111)

Secularists have legitimate concerns about the active engagement by white evangelicals steering IRF discourse. The intimate relationship between conservative white evangelicals and the Republican Party is a contributing factor in the polarisation of the American polity, which also problematises the IRF agenda. The anti-Muslim sentiments and statements expressed by leading figures in the Christian Right, including those involved in the IRF, such as Trump appointees on the USCIRF Gary Bauer, President of American Values, Johnnie Moore, and also Tony Perkins, President of the Family Research Council and Chair of the USCIRF, who has opposed the construction of mosques and the protection of Islam under the First Amendment (Tashman 2015). Given the prominent position occupied by conservative evangelicals, the concern is that they will pursue an agenda which privileges Christianity, highlighting Muslim majority state human right abuses, while ignoring anti-Muslim discrimination, including travel bans from specified Muslim majority countries, restrictions on refugees and Islamophobia domestically (McAlister 2019, p. 111). The extension of IRF to incorporate Freedom of Religion and Belief (FoRB) is interpreted as a rhetorical device cloaking the less benign motivations of evangelicals to enable Christians to proselytise in Muslim majority and other countries, where religion is a matter of practice, culture and community, and not individual belief, which can be adopted and disregarded at will:

These views collide with other conceptions of religion that tie religious identity and practice to blood, soil, family, and community, notably in Judaism, Hinduism, and Confucianism, as well as in many Asian and African folk religions and traditions. In most Muslim milieus, while conversion into the faith is encouraged, conversions out of it are heavily discouraged. These understandings of what constitutes a religious person and community are hardly reconcilable with views of religion as easily, rightfully, and freely changeable individual belief. (Bettiza 2019, p. 85)

For conservative evangelicals, IRF does not stand as a distinct foreign policy, but rather, one which places US Christians alongside their religious brethren across the world, many of whom are indeed experiencing real persecution, harassment and discrimination. IRF challenges legal interpretations of the separation of church and state domestically, enabling conservative evangelicals and others to portray themselves as being denied religious freedom when facing censure in the courts and wider society for opposing same sex marriage, challenging LGBTQ+ legislation, opposition to abortion and advocating prayer in schools. In reifying religion in international contexts, critics of IRF are fearful of the policy provides succour for countries, under the guise of IRF, to continue to discriminate and deny rights to other marginalised groups including LGBTQ+ and retard progress on women's rights.

In designating IRF as a key component of US foreign policy strategy, religion is being co-opted to serve national security and the strategic objectives of the United States, rather than an altruism based on genuine concern for the plight of those suffering persecution on account of their faith. Hurd's objection is that: 'The United States relies on religious actors to secure access to local populations and garner support for American political and strategic objectives in conflict and post-conflict situations' (Hurd 2015, p. 49). The recent track record of US involvement in these situations has been poor. In Afghanistan, Iraq, Libya and Syria, US actions have contributed to greater instability and increased religious persecution. Rather than IRF being seen as a necessary precursor to a positive peace, its close association with US foreign policy calls into question the motivation and the willingness of other countries to be selectively judged and held to account by OIRF and USCIRF reports, with action pursued on the basis of US national interests, rather than the legitimacy of the human rights violation investigated. 


\section{Evaluating the Efficacy of International Religious Freedom Promotion}

Having considered both the outworking of US IRF advocacy and critiques from IRF advocates and secularist opponents, we are now able to evaluate criticism of IRF and begin to tentatively suggest what an efficacious IRF strategy would look like. The first critique examined was from the standpoint of effectiveness, and presents four criticisms of IRF in practice. The first criticism charges successive administrations with being insufficiently committed to the task, because the State Department operates with a secularist bias and is ill-disposed towards factoring religious belief and practice into US foreign policy decision making. While this may have been true in the early years of the IRFA, during the Obama and Trump administrations, considerable progress has been made. Foreign Service Officers have been provided with online religious training programmes, and serve in an environment where religious freedom is increasingly prioritised (Birdsall 2012). The sense of OIRF being marginalised has been arrested through high profile events centring on the OIRF and Ambassador-at-Large Sam Brownback's close working relationship with Pompeo. The ministerials, the UN event on IRF and the establishment of an International Religious Freedom Alliance have moved IRF centre stage. Second, the lackadaisical approach in appointing Ambassadors-at-Large for International Religious Freedom may reflect a lack of due attention to IRF. Obama did not appoint Suzan Johnson Cook until almost the end of his first term, suggesting a disinterest in promoting religious freedom, but then took a further fourteen months to appoint her successor. However, as we have seen, the appointment of David Saperstein provided a new dynamism to the role, and he was supported in the role by Secretary of State Kerry with increased resources. The rabbi's successor Sam Brownback's nomination was delayed through determined opposition by Democrat senators, and did not reflect a lack of engagement or commitment to IRF by the administration. On the contrary, once the appointment was confirmed, he lost no time in working closely with Secretary of State Pompeo in arranging ministerials to build international support and cooperation in promoting IRF.

Third, the charge that successive administrations failed to consider religious freedom strategically in involving religious actors and encouraging religious plurality in Afghanistan and Iraq when devising constitutions and exit strategies. This criticism is cogent, and reflects a dearth of post conflict planning in both countries, however, this planning failure points to the need for such planning in any future interventions, rather than indicating any ongoing lack of commitment for IRF. Birdsall points out that 'Religious freedom did not receive significant attention in the National Security Strategy or the Quadrennial Diplomacy and Development Review. As the Arab Spring unfolded, the Administration could have more vigorously linked religious freedom to democratic reform' (Birdsall 2012, p. 38).

Fourth, critics point to successive administrations' unwillingness to hold countries to account for their actions or inaction. While rhetoric chastising countries for their violations of religious freedom has continued, there remains a wariness about challenging US allies such as Saudi Arabia or India for their poor records in defending religious freedom. While USCIRF will seek to categorise states it considers egregious violators of religious freedom as CPCs, the OIRF will often avoid this categorisation, especially where US national interests are at stake, or where they are optimistic more subtle diplomacy would produce the desired results. USCIRF's 2020 IRF report highlights religious freedom abuses by Burma, China, Eritrea, India, Iran, Nigeria, North Korea, Pakistan, Russia, Saudi Arabia, Syria, Tajikistan, Turkmenistan and Vietnam (USCIRF 2020). Whereas the OIRF has so far not designated India, Russia, Syria and Vietnam as such (OIRF 2019). The State Department did, however, make Pakistan the first new addition since 2016 to its list of CPCs, for severe violations of religious freedom, which had been recommended for such designation by USCIRF since 2002 (USCIRF 2019).

In our examination of the secularist critique of IRF promotion, we observed six specific claims. Firstly, the accusation that IRF is a means of control, a form of governance or regime, which authorises particular forms of politics over others and determines what constitutes legitimate and acceptable religious practices (Hurd 2015; Bettiza 2019). Although it might have been the intention of the IRFA 1998 to make use of US power in a unipolar world to advance US national interests through the imposition of sanctions to control how other countries deal with religion, this has proved impossible to 
deliver. Indeed, IRF is a soft rather than a hard power instrument, and in both the Obama and Trump administrations there has been a reluctance to use sanctions to punish IRF miscreants, unless there were other strategic interests at stake. Second, the secularist discourse positing an IRF advocacy regime seeking to essentialise religion with a historically specific Western-centric focus on individual belief and privilege does, if accurate, stand in contrast to more community orientated approaches, where religion is marked by cultural identity, rather than individual beliefs that can be changed or adapted. However, religious freedom as a basic human right for the individual and community is enshrined in the UDHR, ICCPR and Declaration on the Elimination of All Forms of Intolerance and of Discrimination Based on Religion or Belief. This may be a source of regret to secularists seeking to return religion to the private sphere, but here I agree with Robert Joustra that the complaints: 'against religious freedom seem to me complaints about liberalism and political secularism generally' (Joustra 2016, p. 131).

Third, essentialising or privileging religion as a distinct category is seen as problematic, obscuring the complexities of multifaceted disputes. Seeing the persecution of the Rohinga in Myanmar or Uighur in China in religious terms does indeed simplify complex ethnic, economic and social reasons elevating their religious identity as Muslim as the only issue at stake. However, as Brownback explains:

What makes you also want to do it is in the work that I do I see all these conflicts that have religion as a component of them, whether it's the Rohingya being kicked out of Burma. People say, "Well, that's ethnic." And I said, "No. If these guys were Buddhists they wouldn't be getting kicked out of Burma. But they're Muslims." And so you're just seeing so much of a religious component.

When I was in Nigeria, they're saying, "No, it's ethnic and it's regional and it's resource-driven." And all those are pieces to it, but it is also there is a religious component to this. ${ }^{17}$

The real secularist concern is that IRF is part of a process to desecularise international politics and US foreign policy in particular. Religious actors have a vested interest in influencing the policy, and yet this does not negate the efficacy of IRF, but rather is in tune with contemporary acknowledgement of a post secular world, where it is no longer possible or desirable to seek to contain religion in the private sphere.

Fourthly, the criticism that IRF is biased towards the Christian faith and therefore neglects other religions has a very weak evidential base. Although Christians have made up the majority of USCIRF commissioners, Ambassadors-at-Large, members of the OIRF and Secretaries of State since the IRFA 1998, significant emphasis has been placed on those suffering persecution of other faiths, including Muslims, Jews, Bahai, Buddhists, Hindus, Sikhs, Yazidis, Jehovah's Witnesses and Zoroastrians (OIRF 2019), In Brownback's Special Briefing to the press on IRF in November 2019, the Ambassador-at-Large was accused by a reporter of 'presenting a world in which Muslims are more vulnerable to government mistreatment than Christians' to which he replied that he was 'trying to present a world where you've got just a lot of religious-based oppression that's happening. ${ }^{18}$ A further secularist concern is that IRF is premised on what they believe to be a false notion of Christian persecution, where claims that Christians are the most persecuted religious grouping is rejected. Such persecution is real, however, and overwhelmingly situated in South Asian countries such as India, Nepal, Sri Lanka and Bhutan, where religious nationalism encourages a Buddhist or Hindu hostility towards other faiths; Muslim-majority countries; residual communist countries, including Vietnam, North Korea and China; and authoritarian states, including, Ethiopia, Eritrea, Myanmar, Uzbekistan,

17 Samuel D. Brownback, Special Briefing. Washington, D.C. 21 November 2019. Available at https://www.state.gov/ ambassador-at-large-for-international-religious-freedom-samuel-brownback/ accessed 4 May 2020.

18 Samuel D. Brownback, Special Briefing. Washington, D.C. 21 November 2019. Available at https://www.state.gov/ ambassador-at-large-for-international-religious-freedom-samuel-brownback/ accessed 4 May 2020. 
Turkmenistan and Belarus (Allen 2013; Fox 2006, 2016; Marshall 2016; Open Doors 2020; Pew Research Center 2019; Shortt 2013; Wolf 2011).

Christians persecuted in these countries experience churches being destroyed, imprisonment, torture, abduction, forced marriage and even death. While critics of IRF are right to point out that there is no hierarchy of suffering, and that believers of other faiths also suffer persecution, even that there may be multiple causes for suffering persecution, nonetheless, the extensive persecution of Christians, largely overlooked in the media and public discourse, is a growing cause for concern, according to the Bishop of Truro's Independent Review for the British Foreign Secretary (Mounstephen 2019). A further concern for secularists is that IRF enables Christians to proselytise in Muslim majority countries. Successive administrations have been explicit that this freedom also extends to other faiths, and that to seek to dissuade or prevent people sharing their faith leads to the persecution of those dissenting from the norm within that community.

Fifth, the charge that IRF policy is driven largely by white conservative evangelicals is self-evident within the current administration, several, though not all, USCIRF commissioners, and leading supporters in Congress. It is perhaps worth pointing out, however, that the Ambassador-at-Large is Catholic, and his predecessor was Jewish, the President is not evangelical, and previous members of the OIRF would not fit neatly into the designation of conservative evangelicals, and that IRF has been and remains a bipartisan undertaking. However, undoubtedly Mike Pompeo, a committed Christian who openly discusses and shares his faith, has a close working relationship with fellow conservative evangelicals and Vice President Mike Pence. No previous Secretary of State, since the introduction of IRFA, has been as open about their faith while in office, and as committed to promoting IRF as an outworking of not just US foreign policy but as a faith conviction. ${ }^{19}$ The Trump administration enjoys a symbiotic relationship with white conservative evangelicals, consistently his chief supporters since winning the Republican nomination in 2016. This is a concern for liberals and secularists alike, fearful that IRF promotion, spearheaded by evangelicals, becomes part of America's on-going culture wars, and threatens progress on reproductive, gender and LGBTQ rights around the world. However, the internationalisation of IRF under Saperstein and Brownback, with backing from Secretaries Kerry and Pompeo, dilutes the Americanness of IRF and incorporates religious freedom alongside other human rights.

Finally, the criticism of IRF being a vehicle to co-opt religious actors to deliver US foreign policy objectives is the most prescient. It is difficult to persuade domestic audiences of the necessity or desirability of spending resources on international affairs for diplomacy, aid or democracy promotion, without it being contextualised as being in the US national interest. Nations are rarely altruistic, and seek different tools to enhance their security, prosperity and influence. IRF as a national security strategy is inherently problematic, as other competing interests can trump concerns over promoting religious freedom. It is far easier to talk and act tough and see positive results on religious freedom with smaller countries dependent on US trade or security, than with regional powers, such as India, China or Saudi Arabia, where trade may well have more importance, and they are less likely to take kindly to interference in their internal affairs (Teater 2020). The US has used CPC status and records on religious freedom to castigate political opponents and rivals, including North Korea, China and Iran. Religious actors have been used to highlight human rights abuses in such countries, undermining them while also projecting American soft power as respecters of religious freedom.

IRF is a long-term project, which, over the past two decades, has brought a few tangible gains, such as Sudan's transitional constitution ensuring the freedom of belief and worship and Uzbekistan, improving religious freedom (USCIRF 2020). Numerous prisoners of conscience have been released through a combination of US pressure and diplomacy, including Pastor Andrew Brunson from Turkey.

19 Michael R. Pompeo. Being a Christian Leader. Speech to American Association of Christian Counsellors, Nashville, Tennessee, 11 October 2019. Available at https://www.state.gov/being-a-christian-leader/ accessed 1 April 2020. 
The most significant achievement of IRF advocates, however, has been bringing IRF to the forefront not just of US foreign policy thinking, but also to an international alliance committed to working with all faiths and countries in advancing IRF as a universal value. Religious persecution continues across much of the world, but in establishing a norm of religious freedom and being an effective voice for those suffering religious persecution, there is potential to improve the lived experience of millions of people of faith across the world.

\section{Conclusions}

Over the course of this article I have set out the historical and political background of IRF promotion in US foreign policy, and examined the critiques of this policy from dissatisfied IRF advocates and secularist opponents, to determine what an effective IRF policy would look like. In analysing the critiques, we can now posit what the components of an effective policy would look like:

1. The policy would need to be advanced by those committed to the principle of international religious freedom and appropriately trained to advance religious freedom through diplomacy.

2. The importance of the key role of Ambassador-at-Large for International Religious Freedom would be recognised and appointments made in a timely manner. The success of the role is dependent on a close working relationship with, and support from, the Secretary of State, so direct access, close communication and cooperation is essential to advance a common strategy.

3. IRF would be an essential component in strategic thinking about post conflict settlements.

4. Countries which violate religious freedom would be held to account, irrespective of their strategic importance.

5. There would be no hierarchy of religious belief and practice, with religious freedom protected and advanced without favour.

6. IRF would not be used to unilaterally advance US national interests, but be part of an alliance of like-minded states seeking to uphold international norms of international religious freedom enshrined in the UDHR, and subsequent declarations on freedom of religion and belief.

IRF is a vitally important issue for people of faith suffering persecution around the world. US foreign policy does not have a monopoly of interest on this subject but has, over time, garnered significant international support around the religious freedom so clearly articulated in the UDHR, ICCPR and Declaration on the Elimination of All Forms of Intolerance and of Discrimination Based on Religion or Belief. The work of the OIRF and Ambassadors-at-Large Saperstein and Brownback, in particular, in terms of country visits, patient diplomacy, the two ministerials organised by the OIRF and the formation of the International Religious Freedom Alliance, have served to advance IRF as a universal, rather than an American value. As Secretary of State, Mike Pompeo, working with Brownback and Vice President Pence, has significantly increased the status of IRF as a component of US foreign policy, and strengthened a multilateralist approach to promoting religious freedom. The status of IRF promotion is greater now than at any time since the passing of the IRFA in 1998. Much work still needs to be done, and the components of an effective policy further developed to bring about real change in the lived experiences of people persecuted for their faith, but progress is being made.

Funding: This research received no external funding.

Conflicts of Interest: The author declares no conflict of interest.

\section{References}

Allen, John. 2013. The Global War on Christians: Dispatches from the Front Lines of Anti-Christian Persecution. New York: Penguin Random House.

Andrew, Brother. 2015. God's Smuggler: One Man's Mission to Change the World. London: Hodder \& Stoughton. Bettiza, Gregorio. 2019. Finding Faith in Foreign Policy: Religion and American Diplomacy in a Postsecular World. Oxford and New York: Oxford University Press. 
Birdsall, Judd. 2012. Obama and the Drama over International Religious Freedom Policy: An Insider's Perspective. The Review of Faith E International Affairs 10: 33-41.

Castelli, Elizabeth A. 2007. Persecution Complexes: Identity Politics and the "War on Christians". Differences: A Journal of Feminist Cultural Studies 18: 152-80. [CrossRef]

Castelli, Elizabeth A. 2010. What's the Difference?: Religion and the Question of Theory. Differences: A Journal of Feminist Cultural Studies 21: 124-36. [CrossRef]

Chicago Council on Global Affairs. 2010. Engaging Religious Communities Abroad: A New Imperative for U.S. Foreign Policy. Chicago: The Chicago Council on Global Affairs.

Farr, Thomas F. 2008. World of Faith and Freedom: Why International Religious Liberty Is Vital to American National Security. Oxford and New York: Oxford University Press.

Farr, Thomas F. 2012a. Religious Freedom and International Diplomacy. In The Future of Religious Freedom: Global Challenges. Edited by Allen D. Hertzke. Oxford and New York: Oxford University Press, pp. 331-53.

Farr, Thomas F. 2012b. Back to the Beginning: Rebuilding an Intellectual Consensus for Religious Freedom. The Review of Faith E International Affairs 10: 43-50.

Farr, Thomas F. 2013. Our Failed Religious Freedom Policy. First Things. November. Available online: http://www.firstthings.com/article/2013/11/our-failed-religious-freedom-policy (accessed on 20 May 2020).

Farr, Thomas F. 2014. International Religious Freedom Policy and American National Security. Princeton: The Witherspoon Institute, Available online: http://www.thepublicdiscourse.com/2014/09/13818 (accessed on 1 May 2020).

Fox, Jonathon. 2006. World Separation of Religion and State into the 21st Century. Comparative Political Studies 39: 537-69. [CrossRef]

Fox, Jonathon. 2016. The Unfree Exercise of Religion: A World Survey of Discrimination Against Religious Minorities. Cambridge and New York: Cambridge University Press.

Grim, Brian J. 2008. God's Economy: Religious Freedom and Socio-Economic Well-being. In Religious Freedom in the World. Edited by Paul Marshall. Lanham: Rowman \& Littlefield, pp. 42-47.

Grim, Brian J., and Roger Finke. 2010. The Price of Freedom Denied: Religious Persecution and Conflict in the Twenty-First Century. Cambridge: Cambridge University Press.

Grim, Brian J., Greg Clark, and Robert E. Snyder. 2014. Is Religious Freedom Good for Business? Interdisciplinary Journal for Research on Religion 10: 4.

Hertzke, Allen D. 2004. Freeing God's Children: The Unlikely Alliance for Global Human Rights. Lanham: Rowman \& Littlefield.

Hertzke, Allen D., ed. 2012. The Future of Religious Freedom: Global Challenges. Oxford and New York: Oxford University Press.

Hertzke, Allen D., and Timothy Samuel Shah, eds. 2016. Christianity and Freedom. Volume 2 Contemporary Perspectives. Cambridge: Cambridge University Press.

Hurd, Elizabeth S. 2013. What's Wrong with Promoting Religious Freedom? Foreign Policy. June 12. Available online: http://mideastafrica.foreignpolicy.com/posts/2013/06/12/whats_wrong_with_promoting_religious_ freedom (accessed on 1 May 2020).

Hurd, Elizabeth S. 2015. Beyond Religious Freedom: The New Global Politics of Religion. Oxford and Princeton: Princeton University Press.

Inboden, William. 2012. Religious Freedom and National Security. Policy Review 175: 64. Available online: https://www.hoover.org/research/religious-freedom-and-national-security (accessed on 30 March 2020).

Jewish Telegraph Agency. 1998. Jewish Support Builds for Anti-persecution Bill. April 1. Available online: https: //www.jta.org/1998/04/01/archive/jewish-support-builds-for-anti-persecution-bill-2 (accessed on 1 May 2020).

Joustra, Robert. 2016. Is the Problem Really Religious Freedom? The Review of Faith E International Affairs 14: 129-33.

Leo, Leonard A., and Don Argue. 2012. The US Commission on International Religious Freedom: Challenging the Status Quo. The Review of Faith \& International Affairs 10: 67-72.

Mahmood, Saba. 2015. Religious Difference in a Secular Age: A Minority Report. Princeton: Princeton University Press.

Mandaville, Peter, and Sara Silvestri. 2015. Integrating Religious Engagement into Diplomacy: Challenges $\mathcal{E}$ Opportunities. Issues in Governance Studies 67. Washington: The Brookings Institute. 
Marshall, Paul. 2016. Patterns and Purposes of Contemporary Anti-Christian Persecution. In Christianity and Freedom. Volume 2 Contemporary Perspectives. Edited by Allen D. Hertzke and Timothy Samuel Shah. Cambridge: Cambridge University Press, pp. 58-87.

Marshall, Paul, and Lela Gilbert. 1997. Their Blood Cries Out. Nashville: Thomas Nelson.

Marshall, Paul, and Nina Shea. 2011. Silenced: How Apostasy and Blasphemy Codes are Choking Freedom Worldwide. Oxford: Oxford University Press.

Marshall, Paul, Lela Gilbert, and Nina Shea. 2013. Persecuted: The Global Assault on Christians. Nashville: Thomas Nelson.

McAlister, Melani. 2018. The Kingdom of God Has No Borders. Oxford and New York: Oxford University Press.

McAlister, Melani. 2019. Evangelical Populist Internationalism and the Politics of Persecution. The Review of Faith $\mathcal{E}$ International Affairs 17: 105-17.

Moss, Candida. 2013. The Myth of Persecution: How Early Christians Invented a Story of Martyrdom. New York: HarperCollins.

Mounstephen, Philip. 2019. Bishop of Truro's Independent Review for the Foreign Secretary of FCO Support for Persecuted Christians. Available online: https://christianpersecutionreview.org.uk/report/ (accessed on 4 May 2020).

OIRF. 2018a. Potomac Declaration; Washington: Bureau of Democracy, Human Rights, and Labor, July 24. Available online: https://www.state.gov/ministerial-to-advance-religious-freedom-potomac-declaration/ (accessed on 4 April 2020).

OIRF. 2018b. Potomac Declaration: Plan of Action; Washington: Bureau of Democracy, Human Rights, and Labor, July 24. Available online: https://www.state.gov/ministerial-to-advance-religious-freedom-potomac-planof-action/ (accessed on 4 April 2020).

OIRF. 2019. 2018 Report on International Religious Freedom; Washington: Bureau of Democracy, Human Rights, and Labor. Available online: https://www.state.gov/reports/2018-report-on-international-religious-freedom/ (accessed on 4 May 2020).

OIRF. 2020. Declaration of Principles for the International Religious Freedom Alliance; Washington: Bureau of Democracy, Human Rights, and Labor, February 5. Available online: https://www.state.gov/declaration-of-principlesfor-the-international-religious-freedom-alliance/ (accessed on 2 April 2020).

Open Doors. 2020. World Watch List Report 2020. Witney: Open Doors UK and Ireland.

Pew Research Center. 2019. A Closer Look at How Religious Restrictions Have Risen around the World: Tenth Annual Report Dives Deeper into the Ways Government Restrictions on Religion and Social Hostilities Involving Religion Have Changed, from 2007 to 2017. Washington: Pew Forum on Religion and Public Life, Available online: https://www.pewforum.org/2019/07/15/a-closer-look-at-how-religious-restrictions-haverisen-around-the-world/ (accessed on 3 April 2020).

Philpott, Daniel, and Timothy S. Shah. 2016. In Defense of Religious Freedom: New Critics of a Beleaguered Human Right. Journal of Law and Religion 31: 380-95. [CrossRef]

Pompeo, Michael R. 2019. Unalienable Rights and U.S. Foreign Policy: The Founders' principles can help revitalize liberal democracy world-wide. Wall Street Journal. Available online: https://www.wsj.com/articles/ unalienable-rights-and-u-s-foreign-policy-11562526448 (accessed on 1 May 2020).

Rieffer-Flanagan, Barbara A. 2019. Promoting the Right of Freedom of Religion: Diverse Pathways to Religious Tolerance and Freedom of Religion and the Implications for American Foreign Policy. Human Rights Quarterly 41: 17-38. [CrossRef]

Risse, Mathias. 2020. On American Values, Unalienable Rights, and Human Rights: Some Reflections on the Pompeo Commission. Ethics E International Affairs 34: 13-31.

Seiple, Chris. 2012. Building Religious Freedom: A Theory of Change. The Review of Faith E International Affairs 10: 97-102.

Seiple, Chris, and Dennis R. Hoover. 2012. Religious Freedom and Global Security. In The Future of Religious Freedom: Global Challenges. Edited by Allen D. Hertzke. Oxford and New York: Oxford University Press, pp. 315-30.

Shortt, Rupert. 2013. Christianophobia: A Faith Under Attack. Grand Rapids: Eerdmans.

Stepan, Alfr. 2000. Religion, Democracy and the Twin Tolerations. Journal of Democracy 11: 37-57. [CrossRef]

Sullivan, Winnifred Fallers. 2005. The Impossibility of Religious Freedom. Princeton: Princeton University Press. 
Tashman, Brian. 2015. Tony Perkins: No Religious Liberty for Muslims; Islam 'Incompatible with Constitution'. Right Wing Watch. Available online: https://www.rightwingwatch.org/post/tony-perkins-no-religious-libertyfor-muslims-islam-incompatible-with-constitution/ (accessed on 1 April 2020).

Teater, Kristina M. 2020. U.S. Foreign Policy and the Defense of Religious Freedom in India. Religions 11: 143. [CrossRef]

USCIRF. 2016. USCIRF Annual Report 2016; Washington: United States Commission on International Religious Freedom. Available online: https://www.uscirf.gov/sites/default/files/Overview\%20USICRF\%202016\% 20Annual\%20Report.pdf (accessed on 30 March 2020).

USCIRF. 2019. USCIRF Annual Report 2019; Washington: United States Commission on International Religious Freedom. Available online: https://www.uscirf.gov/sites/default/files/2019USCIRFAnnualReport_ KeyFindingsAndRecommendations.pdf (accessed on 30 March 2020).

USCIRF. 2020. USCIRF Annual Report 2020; Washington: United States Commission on International Religious Freedom. Available online: https://www.uscirf.gov/sites/default/files/USCIRF\%202020\%20Annual\%20Report_ Final_42920.pdf (accessed on 2 May 2020).

Wolf, Frank R. 2011. Prisoner of Conscience: One Man's Crusade for Global Human and Religious Rights. Grand Rapids: Zondervan.

Wurmbrand, Richard. 2004. Tortured for Christ. London: Hodder \& Stoughton.

(C) 2020 by the author. Licensee MDPI, Basel, Switzerland. This article is an open access article distributed under the terms and conditions of the Creative Commons Attribution (CC BY) license (http://creativecommons.org/licenses/by/4.0/). 
MDPI

St. Alban-Anlage 66

4052 Basel

Switzerland

Tel. +41616837734

Fax +41 613028918

www.mdpi.com

Religions Editorial Office

E-mail: religions@mdpi.com www.mdpi.com/journal/religions

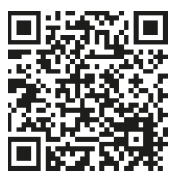



MDPI

St. Alban-Anlage 66

4052 Basel

Switzerland

Tel: +41 616837734

Fax: +41 613028918

www.mdpi.com 